\title{
USO DO DELINEAMENTO III COM MARCADORES MOLECULARES PARA A ANÁLISE GENÉTICA DA PRODUÇÃO DE GRÃOS E SEUS COMPONENTES EM MILHO
}

\author{
AURÉLIO MENDES AGUIAR
}

Tese apresentada à Escola Superior de Agricultura "Luiz de Queiroz", Universidade de São Paulo, para obtenção do título de Doutor em Agronomia, Área de Concentração: Genética e Melhoramento de Plantas.

P I R A C I C A B A

Estado de São Paulo - Brasil

Setembro - 2003 


\title{
USO DO DELINEAMENTO III COM MARCADORES \\ MOLECULARES PARA A ANÁLISE GENÉTICA DA PRODUÇÃO DE GRÃOS E SEUS COMPONENTES EM MILHO
}

\author{
AURÉLIO MENDES AGUIAR \\ Engenheiro Agrônomo \\ Orientador: Prof. Dr. CLÁUDIO LOPES DE SOUZA JÚNIOR
}

\begin{abstract}
Tese apresentada à Escola Superior de Agricultura "Luiz de Queiroz", Universidade de São Paulo, para obtenção do título de Doutor em Agronomia, Área de Concentração: Genética e Melhoramento de Plantas.
\end{abstract}

P I R A C I C A B A

Estado de São Paulo - Brasil

Setembro - 2003 
Dados Internacionais de Catalogação na Publicação (CIP)

DIVISÃO DE BIBLIOTECA E DOCUMENTAÇÃO - ESALQ/USP

\section{Aguiar, Aurélio Mendes}

Uso do delineamento III com marcadores moleculares para a análise genética da produção de grãos e seus componentes em milho / Aurélio Mendes Aguiar. - - Piracicaba, 2003.

$127 \mathrm{p}$.

Tese (doutorado) - Escola Superior de Agricultura Luiz de Queiroz, 2003. Bibliografia.

1. Análise genética 2. Componentes de variância 3. Grãos 4. Marcador molecular 5. Milho 6. Produção agńcola 7. Variação genétic a I. Título

CDD 633.15

"Permitida a cópia total ou parcial deste documento, desde que citada a fonte - $O$ autor" 
Ao povo brasileiro 


\title{
AGRADECIMENTOS
}

\begin{abstract}
A Deus,
por proporcionar conhecer pessoas empenhadas em contribuir para a Ciência, pelas amizades construídas durante o período de convivência em Piracicaba, e aos violeiros e cantadores da terra do Rio de Piracicaba.
\end{abstract}

Gostaria de agradecer também a:

À Escola Superior de Agricultura "Luiz de Queiroz" (ESALQ), particularmente ao Departamento de Genética, por possibilitar a realização deste trabalho.

Ao Conselho Nacional de Desenvolvimento Científico e Tecnológico - CNPq, pela concessão da bolsa de estudo.

Ao Prof. Dr. Magno A. P. Ramalho pelo incentivo na realização deste trabalho e indicação desta escola.

Ao Prof. Dr. Cláudio Lopes de Souza Júnior, pela orientação, ensinamentos, confiança, paciência e amizade.

A Profa. Anete Pereira de Souza e toda equipe do laboratório CEBMEG da Unicamp pela realização das análises laboratoriais.

Aos professores do Departamento de Genética pelos ensinamentos transmitidos.

A todos os funcionários do Departamento de Genética pelo apoio, amizade e condução dos experimentos, em especial a Antônio Juscelino Desidério, Ariberto Soares, Márcio de Araújo, Almir Gil e Rudinei Graciani. 
Aos companheiros de DNA de Piracicaba: Américo Reis, Nelson O. Filho, Juliano Pádua, Mateus Figueiredo, Elizabete Takahashi, Mariza Monteiro, Juliana, Alessandra Fávero, Silvana, Karina Martins, Carolina Morgante, Adriano Castro, Alexandre Missiaggia, Alexandre Coelho, José Ubirajara, Dyeme Bento, Fernando Miranda, Fernando Cárdenas, Ângela Lopes, Ricardo e Lucianinha, Ricardo e Maria Tereza, Maria Zucchi e José Baldin, Mateus Mondin, Milena, Prof. Augusto Garcia, Luciana Benchimol, Prof. José Branco, Luciano Ribas, Viviane Resende, Juan Carlos, Alexander, Vanoli, Francisco Cláudio, Cláudio Tsutsumi, Adelmo Silva, Sérgio Sibov, Francisco Farias, Vanderlei Santos e aos demais colegas da pós-graduação em Genética da ESALQ. Em especial a Luciana Carlini-Garcia, pelas valiosas sugestões e revisão criteriosa da tese.

Aos amigos de outras datas que me incentivaram e apoiaram nesta empreitada: Lanne Gracia, Oswaldo Marques Júnior, Sandro Fuzzato, Pedro Hélio, Thómaz Rossetti, Ricardo (Skilate) e outros.

Aos primos, tios e demais parentes que também me incentivaram.

A Aracruz Celulose S.A. pelo apoio na fase final do trabalho, em especial ao Gabriel Dehon, Fernando Bertolucci e Ergilio C. Silva-Júnior, e os amigos Adriana, Thaís, Ana Gabriela, Antonio Elias, Romualdo, Robert, Sebastião Fonseca, Ricardo, Andréia, Rosária, Otávio, Brás, Sebastião Andrade, Edson Pereira e Erildo.

A meus pais e irmãs pela confiança, amor e compreensão.

Obrigado! 


\section{SUMÁRIO}

Página

LISTA DE FIGURAS................................................................................. viii

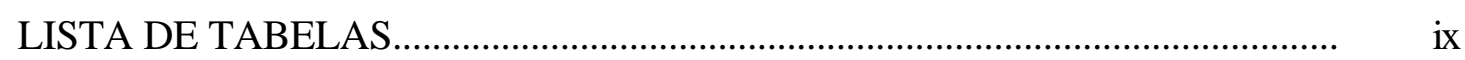

RESUMO_.............................................................................................. $\quad$ xii

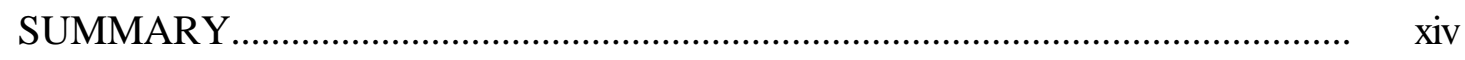

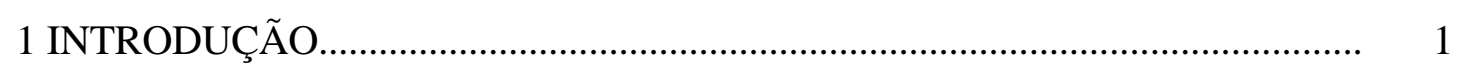

2 REVISÃO DE LITERATURA...................................................................... 3

2.1 Caracteres quantitativos...................................................................................... 3

2.2 Componentes da produção........................................................................... 8

2.2.1 Controle genético dos componentes da produção............................................. 10

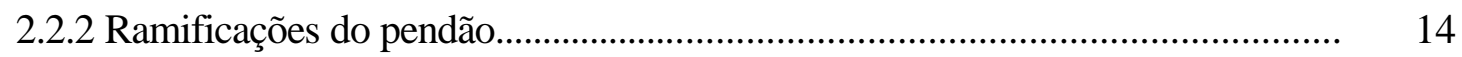

2.3 Delineamento III com marcadores moleculares................................................. 16

3 MATERIAL E MÉTODOS............................................................................. 27

3.1 Material genético.............................................................................................. 27

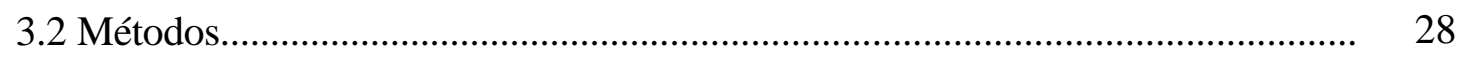

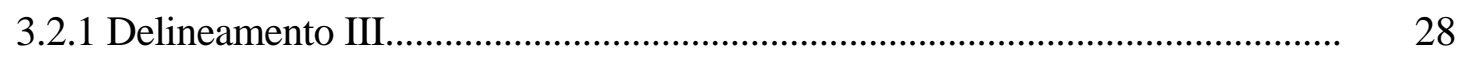

3.2.2 Extração de DNA e genotipagem.................................................................... 30

3.2.3 Mapa genético...................................................................................... $\quad 30$

3.2.4 Condução experimental........................................................................... 31

3.2.4.1 Delineamento experimental e ambientes de avaliação..................................... 31

3.2.4.2 Caracteres avaliados e analisados.............................................................. 32

3.2.5 Análises estatíco-genéticas.......................................................................... 33 
3.2.5.1 Parâmetros genéticos 36

3.2.5.2 Análises de covariâncias e correlações entre caracteres.

3.2.6 Análise genética utilizando o delineamento III com marcadores moleculares..

3.2.6.1 Contrastes

3.2.6.2 Análise de variância para marcador molecular.............................................. 42

4 RESULTADOS E DISCUSSÃO................................................................... 46

4.1 Análise clássica do delineamento III................................................................. 46

4.1.1 Médias e análises de variâncias...................................................................... 46

4.1.2 Componentes de variância................................................................................. 49

4.1.2.1 Produção de grãos........................................................................................... 49

4.1.2.2 Componentes da produção........................................................................ 52

4.1.2.3 Número de ramificações do pendão................................................................ 58

4.2 Correlações entre caracteres................................................................................ 59

4.2.1 Correlações genéticas e fenotípicas envolvendo PG.......................................... 60

4.2.2 Correlações genéticas e fenotípicas entre os componentes da produção............ 62

4.2.3 Correlações genéticas e fenotípicas com o número de ramificações do pendão $\quad 64$

4.3 Considerações sobre a análise clássica do delineamento III................................... 66

4.4 Análise do delineamento III com marcadores moleculares.....................................

4.4.1 Produção de grãos............................................................................................... 69

4.4.2 Componentes da produção................................................................................. 75

4.4.3 Número de ramificações do pendão..................................................................... 81

4.5 Considerações finais.................................................................................... 83

5 CONCLUSÕES.................................................................................... 89

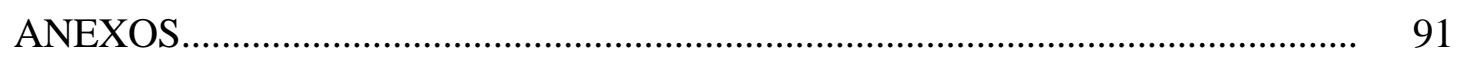

REFERÊNCIAS BIBLIOGRÁFICAS.............................................................. 113

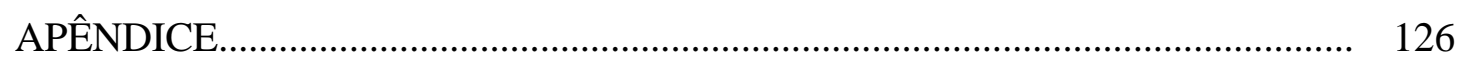




\section{LISTA DE FIGURAS}

Página

1 Mapa genético com 140 marcadores microssatélites distribuídos nos 10 cromossomos do milho, constituído de 1730,1 centiMorgam (cM) de extensão e 12,4 cM de intervalo médio entre marcadores adjacentes................................ 92

2 Distribuição do somatório, em módulo, dos efeitos genéticos (aditivos, dominantes e epistáticos) para os caracteres de PG, PROL, DE e CE................ 93

3 Distribuição do somatório, em módulo, dos efeitos genéticos (aditivos, dominantes e epistáticos) para os caracteres RP, P500, NGF e NFI............. 93 


\section{LISTA DE TABELAS}

Página

1 Valores genotípicos das progênies retrocruzadas para as linhagens genitoras ( $\mathrm{L}_{1}$ e $\mathrm{L}_{2}$ ), considerando um QTL (gene $\mathrm{B}$ ), para um determinado genótipo do marcador molecular.

2 Resumo da análise da variância do delineamento III avaliado em um local com as respectivas esperanças matemáticas das fontes de variação de interesse.

3 Resumo da análise de variância e teste $F$, com as respectivas esperanças matemáticas dos quadrados médios das fontes de variação da análise conjunta agrupada utilizando o delineamento III.

4 Resumo da análise de variância com as esperanças matemáticas dos quadrados médios e teste $\mathrm{F}$ para o marcador $s$, considerando o delineamento III associado a marcadores moleculares (Cockerham \& Zeng, 1996).

5 Resumo das análises de variâncias conjuntas agrupadas para produção de grãos, seus componentes e para número de ramificações do pendão, médias das progênies retrocruzadas com as linhagens genitoras L-08-05F e L-14-04B e suas amplitudes. 
6 Estimativas de parâmetros genéticos e seus respectivos intervalos de confiança a 0,95 de probabilidade, para produção de grãos, seus componentes e número de ramificações do pendão

7 Estimativas das correlações aditivas ( $\hat{r}_{a}$, acima da diagonal), genéticas ( $\hat{r}_{g}$, abaixo da diagonal) e fenotípicas ( $\hat{r}_{\bar{F}}$, entre parênteses), entre os caracteres analisados.

8 Estimativas e significâncias dos coeficientes de regressão parciais ( $\hat{a}^{\prime} \mathrm{s}$ ) para os caracteres produção de grãos (PG) e prolificidade (PROL).

9 Estimativas e significâncias dos coeficientes de regressão parciais ( $\hat{a}^{\prime} s$ ) para os caracteres diâmetro da espiga (DE) e comprimento da espiga (CE).

10 Estimativas e significâncias dos coeficientes de regressão parciais ( $\hat{a}^{\prime} \mathrm{s}$ ) para os caracteres número de grãos por fileira (NGF) e número de fileiras por espiga (NFI).

11 Estimativas e significâncias dos coeficientes de regressão parciais (ấs) para os caracteres número de ramificações do pendão (RP) e peso de 500 grãos (P500)

12 Número de marcadores com significância para os coeficientes $\hat{\beta}_{1}, \hat{\beta}_{2}, \hat{\beta}_{3}$ e $\hat{\beta_{4}}$, e suas interações com ambientes, entre parênteses, em cada cromossomo para os caracteres produção de grãos (PG), prolificidade (PROL), diâmetro da espiga (DE) e comprimento da espiga (CE) 
13 Número de marcadores com significância para os coeficientes $\hat{\beta_{1}}, \hat{\beta_{2}}, \hat{\beta}_{3}$ e $\hat{\beta_{4}}$, e suas interações com ambientes, entre parênteses, em cada cromossomo para os caracteres número de ramificações por pendão (RP), peso de 500 grãos (P500), número de grãos por fileira por espiga (NGF) e número de fileiras por espiga (NFI).

14 Amplitude de variação das estimativas dos coeficientes de regressão significativos para os caracteres PG, PROL, DE, CE, NGF, NFI, P500 e RP....

15 Resumo das análises de variâncias agrupadas por ambiente para a produção de grãos e seus componentes e ramificações do pendão. 


\title{
USO DO DELINEAMENTO III COM MARCADORES MOLECULARES PARA A ANÁLISE GENÉTICA DA PRODUÇÃO DE GRÃOS E SEUS COMPONENTES EM MILHO
}

\author{
Autor: AURÉLIO MENDES AGUIAR \\ Orientador: Prof. Dr. CLÁUDIO LOPES DE SOUZA JÚNIOR
}

\section{RESUMO}

O delineamento III foi proposto para estimar as variâncias aditivas e de dominância e o grau médio de dominância de caracteres quantitativos. Com o advento dos marcadores moleculares, Cockerham \& Zeng (1996) desenvolveram uma metodologia genético-estatística associando o delineamento III com marcadores moleculares. Esta metodologia foi proposta visando estimar, com o uso de quatro contrastes ortogonais, os efeitos aditivos, dominantes e epistáticos dos QTLs ligados a marcadores moleculares. O objetivo desta pesquisa foi usar ambas as metodologias para análise genética da produção de grãos, componentes da produção e número de ramificações do pendão em uma população referência $F_{2}$ de milho. Duzentos e cinqüenta progênies $F_{2: 3}$ foram retrocruzadas com ambas linhagens genitoras, dando origem a 500 progênies de retrocruzamento. Estas progênies foram alocadas em cinco látices 10x10 e avaliadas em seis ambientes em três estações experimentais próximas a Piracicaba, SP, com duas repetições por ambientes. Estimativas de variância aditiva e de dominância, assim como o grau médio de dominância dos caracteres avaliados, apresentaram magnitudes similares às reportadas em populações de milho temperado para todos os caracteres. Estimativas do grau médio de dominância foram inferiores a um para o 
diâmetro da espiga, número de fileiras, peso de 500 grãos e número de ramificações do pendão, mostrando que os efeitos aditivos foram mais importantes que os efeitos de dominância para estes caracteres. Para prolificidade, comprimento da espiga e número de grãos por fileira, o grau médio de dominância não diferiu de dominância completa, sugerindo que os efeitos de dominância foram importantes para estes caracteres. Para produção de grãos, o resultado do grau médio de dominância sugeriu sobredominância. Porém, como é conhecido, o desequilíbrio de ligação causa viéses nas estimativas de grau médio de dominância e, consequientemente, estas estimativas podem ser menores, sendo que, provavelmente tenha ocorrido pseudo-sobredominância para produção de grãos. A análise do delineamento III com marcadores moleculares mostrou que os QTLs estão distribuídos em todos os cromossomos para todos caracteres. As somas em módulo dos efeitos dos QTLs mostraram que para produção de grãos, prolificidade, comprimento da espiga, e número de grãos por fileira, os efeitos de dominância foram superiores aos efeitos aditivos, e estes superiores aos efeitos epistáticos; para diâmetro da espiga, peso de 500 grãos, número de fleiras, e número ramificações do pendão, os efeitos aditivos foram maiores que os efeitos de dominância, e estes superiores aos efeitos epistáticos, exceto para número de fileiras em que os efeitos epistáticos foram maiores que os efeitos de dominância. Os efeitos epistáticos foram detectados para todos caracteres e contribuíram mais para os componentes da produção que para a produção de grãos per se. A análise clássica do delineamento III e a associada a marcadores moleculares forneceram resultados de grande utilidade, mas o delineamento III com marcadores permitiu a estimação dos efeitos genéticos de regiões específicas do genoma e sugeriu que os efeitos epistáticos foram muito importantes na expressão e na herança dos caracteres analisados. 


\title{
USE OF THE DESIGN III WITH MOLECULAR MARKERS FOR THE GENETIC ANALYSIS OF GRAIN YIELD AND ITS COMPONENTS IN MAIZE
}

\author{
Author: AURÉLIO MENDES AGUIAR \\ Adviser: Prof. Dr. CLÁUDIO LOPES DE SOUZA JÚNIOR
}

\section{SUMMARY}

The Design III was proposed to estimate additive and dominance variances, and the average levels of dominance of quantitative traits. With the advent of the molecular markers, Cockerham \& Zeng (1996) developed a genetic-statistical procedure using the Design III with molecular markers. This procedure was designed to estimate additive, dominance and epistatic effects of the QTLs linked to molecular markers from four orthogonal contrasts. The objectives of this research were to use both methodologies for the genetic analysis of grain yield, yield components, and number of tassel branches in an $F_{2}$ reference maize population. Two-hundred and fifty $F_{2: 3}$ progenies were backcrossed to the two parental inbred lines, which gave rise to 500 backcrossed progenies. These progenies were allocated in five 10x10 lattices design, and evaluated in six environments in three experimental stations near Piracicaba, SP, with two replications per environment. Estimates of additive and dominance variances, as well as the average levels of dominance for the traits evaluated, had magnitudes similar to those already reported for temperate maize populations for all traits. Estimates of the average level of dominance were lower than one for ear diameter, kernel row number, weight of 500 kernels, and tassel branches number, showing that the additive effects were more 
important than the dominance effects for these traits. For prolificacy, ear length, and kernels per row number, the average levels of dominance did not differ from complete dominance, suggesting that the dominance effects were important for these traits. For grain yield, the result suggested overdominance as the average level of dominance. However, as is well-known, linkage disequilibrium causes biases in the estimates of the average levels of dominance and, therefore, these estimates could be lower, and probably for grain yield a pseudo-overdominance was detected. The analysis of the Design III with molecular markers showed that QTLs were distributed in all chromosomes for all traits. The sum in module of the QTLs effects showed that for grain yield, prolificacy, ear length, and kernels per row number, dominance effect was greater than additive effect, and the latter greater than epistatic effect; whereas for ear diameter, weight of 500 kernels, kernel row number, and tassel branches number, additive effect was greater than dominance effect, and the latter greater than epistatic effect, except for kernel row number where epistatic effect was greater than dominance effect. Epistatic effects were detected for all traits, and had higher contribution for the yield components than for yield per se. Both traditional and QTL analysis of the Design III presented very useful results, but the Design III with molecular markers allowed the estimation of the genetic effects from specific genomic regions, and suggested that the epistatic effects play a very important role for the expression and inheritance of the traits assessed. 


\section{INTRODUÇÃO}

A maioria dos caracteres de importância econômica é controlada por um grande número de genes, e geralmente influenciada pelas condições ambientais, e são denominados de caracteres quantitativos ou poligênicos. Esta teoria foi proposta independentemente por Nilsson-Ehle e East em 1910 e ficou conhecida como "hipótese dos fatores múltiplos". Estes genes, em sua maior parte, são de pequeno efeito e responsáveis pelo controle genético dos diversos processos metabólicos envolvidos nos caracteres quantitativos. Devido a isso, em geral, os caracteres quantitativos apresentam distribuição contínua, não permitindo a utilização dos procedimentos clássicos Mendelianos no estudo destes caracteres. Assim, são utilizados parâmetros estatísticos como médias, variâncias, coeficientes de regressão e correlação, entre outros, no estudo da herança destes caracteres.

As ferramentas estatísticas aplicadas à Genética auxiliaram no entendimento de processos evolutivos e no estudo dos efeitos gênicos dos caracteres quantitativos. O conhecimento da herança destes caracteres é importante para o direcionamento adequado dos recursos nos programas de melhoramento (Hallauer \& Miranda Filho, 1988). Além disso, estimativas de parâmetros genéticos permitem ao melhorista identificar o melhor método de seleção através da avaliação das respostas esperadas e de suas eficiências relativas (Souza Júnior, 1988).

O desenvolvimento de marcadores moleculares nas últimas décadas do século passado abriu perspectivas promissoras para a análise de caracteres quantitativos, pois permitem detectar, mapear e estimar os efeitos dos locos que controlam estes caracteres (QTLs), e suas interações com ambientes. Simultaneamente à evolução das técnicas de marcadores moleculares, as metodologias para a detecção ou mapeamento de QTLs e a 
obtenção de estimativas dos seus efeitos genéticos, apresentaram rápido desenvolvimento (Lynch \& Walsh, 1998).

Dentre os métodos de análise genética com marcadores moleculares, destaca-se o de Cockerham \& Zeng (1996), os quais propuseram a associação do delineamento III, de Comstock \& Robinson (1948), com marcadores moleculares. A abordagem clássica do delineamento III permite estimar os componentes de variância genética (aditiva e dominante) e o grau médio de dominância do caráter avaliado, e foi muito utilizado nos programas de melhoramento, principalmente em milho. A associação com marcadores moleculares permite a estimação dos efeitos gênicos (efeitos aditivos, dominantes e epistáticos) dos QTLs associados a marcadores, bem como suas interações com ambientes. Apesar da existência de inúmeras pesquisas que realizaram a análise genética de diversos caracteres de importância econômica/agronômica em milho tropical (Vencovsky et al., 1988) resultado oriundo da análise do delineamento III com marcadores foi relatado apenas por Silva (2002) para diversos caracteres. Assim, estimativas de componentes de variância, grau médio de dominância, e de efeitos genéticos de médias relatados referem-se em sua maior parte a germoplasma de milho temperado (Hallauer \& Miranda Filho, 1988). Diante do exposto, o objetivo desta pesquisa foi realizar a análise genética da produção de grãos em milho e de seus componentes, utilizando-se da análise clássica do delineamento III e a análise deste com marcadores moleculares. 


\section{REVISÃO DE LITERATURA}

\subsection{Caracteres quantitativos}

Em programas de melhoramento de plantas, geralmente, os caracteres de importância econômica são controlados por um grande número de genes de pequeno efeito que são influenciados pelas condições ambientais, os quais são denominados de caracteres quantitativos ou poligênicos. Estes caracteres, freqüentemente, não podem ser agrupados em classes distintas, pois há sobreposição entre as classes fenotípicas, originando uma distribuição contínua das medidas do caráter (Mather \& Jinks, 1984; Falconer \& Mackay, 1996). Em milho, a grande maioria dos caracteres de importância econômica são caracteres quantitativos. Dentre eles, podem-se citar produção de grãos, prolificidade, peso do grão, diâmetro da espiga, comprimento da espiga, altura da espiga, altura da planta, teor de óleo e de proteína nos grãos, entre inúmeros outros. Apesar disso, alguns caracteres quantitativos, geralmente providos de contagem, podem apresentar distribuição discreta, tais como prolificidade, número de folhas e número de fileiras de grãos em milho. Estes caracteres são denominados de umbral ("threshold traits") (Hallauer, 1974; Motto \& Moll, 1983).

No estudo da herança de caracteres quantitativos, os geneticistas utilizam uma abordagem biométrica, em que um caráter é função da sua constituição genética, do efeito ambiental e da interação de genótipos com ambientes (Hallauer \& Miranda Filho, 1988; Ramalho et al., 1993; Falconer \& Mackay, 1996; Lynch \& Walsh, 1998). Diversos delineamentos genéticos foram propostos com o intuito de estimar as variâncias associadas aos efeitos genéticos dos genes que controlam os caracteres quantitativos. Em meados do século passado, Comstock \& Robinson (1948, 1952) propuseram três 
delineamentos genéticos que se tornaram clássicos no melhoramento de plantas. Inúmeros autores adotaram estes delineamentos no estudo de caracteres quantitativos em diferentes espécies. As informações geradas foram responsáveis, em grande parte, pelo sucesso do melhoramento de plantas ao longo deste período. Para a produção de grãos em milho, por exemplo, foram realizados inúmeros trabalhos de estimação dos parâmetros genéticos. Utilizando o delineamento III, a maioria dos trabalhos relataram estimativas de variância aditiva semelhante à variância de dominância, e estimativas de grau médio de dominância em torno de 1,00, evidenciando a importância dos efeitos aditivos e de dominância no controle deste caráter (Robinson et al., 1949; Gardner et al., 1953; Gardner \& Lonquist, 1959; Moll et al., 1964; Han \& Hallauer, 1989; Cockerham \& Zeng, 1996; Wolf et al., 2000; Silva, 2002). Estas informações serviram de referência para que os melhoristas adotassem estratégias de melhoramento visando capitalizar estes efeitos genéticos, como a utilização da seleção recorrente recíproca para a seleção de híbridos. Também é muito comum encontrar nestes trabalhos estimativas de pequena magnitude para a herdabilidade, evidenciando a influência dos efeitos ambientais no controle genético de caracteres quantitativos. Esta constatação evidencia que a precisão experimental é primordial para a obtenção de sucesso nos programas de melhoramento de milho para caracteres quantitativos. Apesar de todo esforço despendido no estudo dos caracteres quantitativos em diferentes espécies, algumas questões ainda permanecem obscuras, como a ocorrência do efeito de sobredominância e a importância dos efeitos epistáticos no controle destes caracteres.

Os melhoristas de plantas utilizam diversas ferramentas para auxiliar na identificação de genótipos superiores em uma população segregante. Dentre estas ferramentas, os marcadores moleculares têm-se mostrado de grande potencial no melhoramento de plantas. Já no início do século passado, Sax (1923) associou marcadores morfológicos (coloração do grão de feijão) com caracteres quantitativos (tamanho do grão). Porém o desenvolvimento destes estudos foi dificultado devido ao pequeno número de marcadores morfológicos disponíveis, à dificuldade de obtenção de população segregante para estes marcadores e herança dominante do marcador (Bearzoti, 
2000). Somente com o desenvolvimento e aperfeiçoamento das técnicas de marcadores moleculares é que o mapeamento destes caracteres voltou a receber atenção dos pesquisadores, com o intuito de entender melhor como os genes atuam no controle genético destes caracteres e como podem ser utilizados em programas de melhoramento de plantas.

Alguns delineamentos genéticos propostos com o objetivo de estudar o controle genético dos caracteres quantitativos foram adaptados para o estudo de mapeamento genético. Os principais delineamentos utilizam linhagens homozigóticas como genitores, isso para gerar populações segregantes com o máximo de desequilíbrio de ligação. Os desvios em relação às proporções esperadas pela segregação independente de alelos de locos diferentes é que permitem a detecção e mapeamento de QTLs ("QuantitiveTrait Loci") (Bearzoti, 2000). Além de cruzamentos controlados, a migração e a seleção podem gerar desequilíbrio de ligação. Por apresentarem o máximo desequilíbrio de ligação, populações $F_{2}$ são comumente utilizadas em estudos de mapeamento. Young (1994) considera essa população como sendo a mais indicada para a construção de mapas moleculares. O inconveniente da utilização deste tipo de geração é que os indivíduos desta população são únicos, não permitindo a avaliação em experimentos com repetições e em vários locais. Visando resolver esta limitação, Lynch \& Walsh (1998) comentam que a genotipagem pode ser realizada em plantas da geração $\mathrm{F}_{2}$ e o caráter quantitativo avaliado em progênies $F_{2: 3}$, as quais produzem maior número de sementes e podendo, conseqüentemente, ser avaliadas em experimentos com repetições e em vários locais.

Populações obtidas por retrocruzamentos ("backcrosses") também são utilizadas no mapeamento de QTLs. A utilização de plantas retrocruzadas $\left(\mathrm{F}_{1}\right.$ x genitor A ou B) apresenta o mesmo problema verificado para a geração $F_{2}$, ou seja, os indivíduos são únicos, o que compromete a precisão da avaliação fenotípica. Aqui também pode-se adotar a mesma estratégia para aumentar o número de sementes, ou seja, a produção de progênies $F_{2: 3}$ retrocruzadas. Este artifício é permitido já que uma progênie $F_{2: 3}$ representa os gametas da planta $\mathrm{F}_{2}$ correspondente. $\mathrm{O}$ delineamento III proposto por Comstock \& Robinson (1948, 1952), utiliza plantas $F_{2}$ retrocruzadas para ambos 
genitores, com o objetivo de estimar o grau médio de dominância do caráter em questão. Cockerham \& Zeng (1996) associaram o delineamento III com marcadores moleculares, porém, enfatizaram que o principal objetivo da metodologia é a estimação dos efeitos genéticos (aditivos, dominantes e epistáticos) dos QTLs ligados aos marcadores moleculares, bem como de suas interações com ambientes.

Outro tipo de população adotada em trabalhos de mapeamento são linhagens puras recombinantes ("recombinant inbred lines"). Este delineamento utiliza o desequilíbrio de ligação que permanece em um conjunto de linhagens puras derivadas por autofecundações sucessivas de plantas $F_{2}$ (Bearzoti, 2000). A população de linhagens recombinantes apresenta desequilíbrio de ligação menor que a geração $F_{2}$, diminuindo o poder de detecção de QTLs, porém, permite que os genótipos sejam perpetuados, proporcionando a avaliação em diversos ambientes em experimentos com repetições. Linhagens duplo-haplóides, formadas a partir da duplicação de gametas de plantas $\mathrm{F}_{1}$, também são adotadas em estudos de mapeamento. Este tipo de população apresenta a vantagem de poder perpetuar os genótipos, como as linhagens recombinantes, e apresenta um desequilíbrio de ligação superior ao verificado para linhagens recombinantes. $\mathrm{O}$ inconveniente é que apenas algumas espécies de plantas permitem a obtenção de linhagens duplo-haplóides. A escolha de qual tipo de população adotar no mapeamento de QTLs vai depender das particularidades da espécie, como a viabilidade de realizar cruzamentos controlados, capacidade de suportar autofecundações (depressão por endogamia) e produção de sementes. Em animais e espécies que não permitem autofecundações, são adotados outros delineamentos, detalhes a respeito são apresentados por Lynch \& Walsh (1998).

Diversas metodologias foram desenvolvidas visando identificar a ligação de um marcador a um QTL. A análise baseada em um único marcador ("single point analysis") é o procedimento mais simples para se detectar QTLs. Tanksley (1993) comenta que esta metodologia apresenta a desvantagem de quanto maior a distância entre o marcador e o QTL, menor é a probabilidade de detectá-lo. Esse fato também afeta a magnitude do QTL, que normalmente é subestimado, já que este procedimento não permite a estimação 
dos parâmetros genéticos do modelo em conjunto com a posição do loco em questão (Liu, 1998). Este fato decorre de que quanto maior a distância entre o marcador e o QTL, maior será a frequiência de recombinação. Devido a isso, a estimativa da magnitude do efeito do QTL fica prejudicada, não permitindo a distinção de um QTL de pequeno efeito situado próximo ao marcador de um QTL de grande efeito situado mais distante do marcador (Lynch \& Walsh, 1998). Tanksley (1993) argumenta que estas desvantagens podem ser minimizadas com utilização de um grande número de marcadores segregantes cobrindo todo o genoma. Neste caso, os QTLs em potencial estariam fortemente ligados a pelo menos um marcador. Para testar a ligação de um marcador a um QTL, é realizado um teste entre as médias fenotípicas associada às classes genotípicas do marcador (Falconer \& Mackay, 1996). O teste $t$, regressão linear simples, análise de variância e razão de verossimilhança (LODscore) são utilizados na identificação de QTLs ligados a marcadores moleculares.

Lander \& Botstein (1989) apresentaram o mapeamento por intervalo. Esta metodologia é uma extensão do método de máxima verossimilhança para marcas simples. Este método baseia-se nas freqüências conjuntas de um par de marcas adjacentes e um QTL potencial, flanqueado por essas duas marcas. Uma alternativa para o mapeamento de QTLs é a aproximação de Haley \& Knott (1992), que utiliza regressão linear múltipla para mapear QTLs flanqueados por duas marcas.

Apesar do avanço destas técnicas em relação à análise de marca simples, o mapeamento por intervalo pode apresentar o problema de identificação de "QTLs fantasmas", isto é, localizar um QTL inexistente. Visando eliminar este efeito, Jansen (1992, 1993) e Zeng (1993, 1994), independentemente, propuseram o mapeamento por intervalo composto, baseado em um modelo de regressão múltipla com o método da máxima verossimilhança. O enfoque utilizado por Haley \& Knott (1992) também pode ser adotado no mapeamento por intervalo.

Kao et al. (1999) propuseram a técnica de mapeamento por intervalo múltiplo ("Multiple Interval Mapping - MIM"). Este método baseia-se no modelo de Cockerham (1954) para interpretação de parâmetros genéticos e no método de máxima 
verossimilhança. O MIM apresenta algumas vantagens potenciais, como maior eficiência e precisão na identificação de QTLs; entendimento e identificação de padrões epistáticos; os efeitos epistáticos são estimados sem viéses, ao contrário de outros métodos; pode-se aumentar a eficiência da seleção assistida por marcadores, capitalizando os efeitos epistáticos.

\subsection{Componentes da produção}

O melhoramento para produção de grãos geralmente é dificultado pela baixa herdabilidade deste caráter. Isto é devido ao grande número de genes envolvidos no seu controle e a suas interações com ambientes. Alguns autores propuseram estudar os componentes da produção, visando identificar caracteres que apresentassem magnitude mais elevada de herdabilidade, para que a seleção indireta de um ou mais componentes pudessem melhorar a eficiência da seleção da produção de grãos. Para isso, é necessário que um dos componentes tenha herdabilidade maior que a da produção de grãos e apresente uma elevada correlação com este caráter (Johnson et al., 1966; Paroda \& Joshi, 1970; Smith, 1976; Alexander et al., 1984; Falconer \& Mackay, 1996). Na literatura, são apresentados trabalhos com algumas culturas em que se verificaram tanto sucessos na seleção indireta baseada nos componentes da produção quanto insucessos (Sidwell et al., 1976; McNeal et al., 1978; Whan et al., 1982; Mareck \& Gardner, 1979; Alexander et al., 1984). Estes resultados mostram que o sucesso obtido com uso desta estratégia depende da correlação entre os caracteres, das condições de avaliação e do germoplasma utilizado.

O estudo dos componentes da produção e de suas relações com a produção de grãos, permite prever alterações nos componentes ao longo dos ciclos de seleção. Feil (1992) observou que em muitos cereais melhorados houve aumento no número de sementes produzidas e não um aumento no peso do grão. Moser \& Frey (1994), estudando o efeito da seleção recorrente sobre os componentes da produção em aveia, verificaram que as linhagens do quinto ciclo de seleção recorrente eram mais produtivas do que as do primeiro ciclo por apresentarem maior desenvolvimento vegetativo, 
proporcionando condições para a produção de um maior número de sementes. Pereira (1990), avaliando variedades indígenas, variedades melhoradas e híbridos comerciais brasileiros de milho, obteve que o melhoramento para produção de grãos aumentou a prolificidade, além de diminuir as ramificações do pendão. Resultados similares já haviam sido relatados por Gardner (1977), Moll \& Kamprath (1977), Mareck \& Gardner (1979), Meghji et al. (1984) e Souza Júnior et al. (1985).

$\mathrm{Na}$ literatura, há um grande número de trabalhos relacionados aos componentes da produção em diversas culturas (Tavares, 1972; Harris et al., 1976; Payne et al., 1986; Tyagi et al., 1988; Sobrado, 1990; Singh et al., 1992; Vidal-Martínez et al., 2001; e outros). Nestas pesquisas foram estudados vários aspectos dos componentes da produção, tais como fisiológicos (Duncan et al., 1978; Payne et al., 1986; Maddonni et al., 1998; Otegui \& Bonhomme, 1998), capacidade de combinação (Geadelmann \& Peterson, 1976; Singh et al., 1992), heterose (Leng, 1954; Grafius, 1959; Tavares, 1972; Mehta \& Sarkar, 1992), depressão por endogamia (San Vicente \& Hallauer, 1993; Benson \& Hallauer, 1994; Cardoso, 1999), coeficiente de trilha (Tyagi et al., 1988; Arias et al., 1999) e, atualmente, detecção de QTLs associados aos componentes da produção (Veldboom \& Lee, 1994; Berke \& Rocheford, 1995, 1999; Austin \& Lee, 1996, 1998; Ribaut et al., 1997; Mickelson et al., 2002).

Moser \& Frey (1994) apresentam outras vantagens importantes de se estudar os componentes da produção: i) identificar o componente específico de acordo com os objetivos do programa de melhoramento (McMullan et al., 1988); ii) gerar hipóteses que permitam aumentar os ganhos de produção (Payne et al., 1986); iii) detectar quais genes de um componente específico da produção podem ser usados para aumentar a produção quando incorporados em um conjunto gênico elite, assumindo que a compensação entre a interação dos componentes da produção possa ser minimizada (Rasmusson, 1987; Frey, 1988). Atualmente, com o advento de técnicas de marcadores moleculares e mapeamento de QTLs, o item iii pode se tornar muito vantajoso, visando a incorporação de genes específicos associados a alguns dos componentes da produção. 
Em milho, o primeiro relato sobre os componentes da produção foi feito por Leng (1954). Este autor dividiu os componentes em primários e secundários. Foram alocados como componentes primários os caracteres prolificidade, peso do grão, número de fileiras e número de grãos por fileira, e como componentes secundários, os caracteres peso de grãos por espiga e número de grãos por espiga. Grafius (1959) propôs que a produção de grãos $(W)$ em cevada e milho poderia ser descrita como uma função multiplicativa $(W=R . S . T . U)$ dos caracteres número de espigas $(R)$, número de grãos por fileira $(S)$, número de fileiras de grãos $(T)$ e peso do grão $(U)$. Este autor admite que estes componentes sejam não correlacionados, isto é, cada componente é controlado por um grupo de genes específicos, não existindo um grupo de genes para a produção de grãos.

\subsubsection{Controle genético dos componentes da produção}

O estudo dos caracteres relacionados com a produção de grãos é relativamente comum na literatura. Em milho os primeiros trabalhos com os componentes da produção foram apresentados por Leng (1954). Nestes trabalhos foram avaliados 92 cruzamentos $\mathrm{F}_{1}$ e as respectivas linhagens genitoras. Os híbridos avaliados apresentaram menor número de espigas por planta, aproximadamente o mesmo número de fileiras, grãos com cerca de $8 \%$ mais peso e $42 \%$ mais grãos por fileira, comparados com as linhagens genitoras superiores. A estimativa da heterose foi maior para o peso de grãos por espiga e para o número de grãos por espiga.

Dentre os componentes da produção, a capacidade da planta produzir mais de uma espiga (prolificidade) foi a mais estudada. Tem sido relatado que a prolificidade em milho pode auxiliar os melhoristas a identificar genótipos mais estáveis e produtivos (Hallauer, 1974; Motto \& Moll, 1983). Este caráter fornece aos genótipos maior capacidade de suportar as variações de densidade de semeadura, nível de fertilidade e estresses hídricos, sem grande alteração na produção de grãos (Russel \& Eberhart, 1968; Undersander, 1987). Diversos trabalhos também têm relatado correlação positiva e elevada entre a produção de grãos e a prolificidade (Robinson et al., 1951; Goodman, 
1965; Lonquist et al., 1966; Stuber et al., 1966; Mareck \& Gardner, 1979; Souza Júnior et al, 1985; Tyagi et al., 1988; Ribaut et al., 1997; Arias et al., 1999). Em revisão realizada por Hallauer \& Miranda Filho (1988) os autores apresentam uma média de herdabilidade entre parcelas de diversos trabalhos apresentados na literatura. Os autores relataram que, em média, as estimativas de herdabilidade para produção de grãos foram inferiores as obtidas para os caracteres prolificidade, comprimento da espiga, diâmetro da espiga e número de grãos por fileira.

Com relação ao controle genético da prolificidade, há inúmeros trabalhos que divergem quanto ao número de genes que controlam o caráter e o tipo de ação gênica predominante. Motto \& Moll (1983) apresentaram uma revisão extensa sobre prolificidade e comentaram que a ação gênica depende do material adotado no trabalho e das condições ambientais. Hallauer (1974), estudou o controle genético da prolificidade, foram avaliadas as gerações $F_{1}, F_{2}$ e os retrocruzamentos de sete cruzamentos sob três densidades de semeadura. $\mathrm{O}$ autor concluiu que a herança da prolificidade é complexa, altamente dependente dos genótipos avaliados, bem como das condições de avaliação. As estimativas de herdabilidade para prolificidade dos sete cruzamentos avaliados, variaram de 0,00 a 0,72 , sendo a média igual a 0,32. Hallauer \& Miranda Filho (1988) relataram uma média de 0,39 para a herdabilidade entre parcelas, obtida de 39 trabalhos. Utilizando o delineamento III, Gardner \& Lonquist (1959) estudaram o efeito da ligação sobre as estimativas de grau médio de dominância $(\hat{\bar{d}})$ de uma população originada de linhagens do "Corn Belt" norte-americano. Os autores obtiveram estimativas de $\hat{\bar{d}}$ nas gerações $\mathrm{F}_{2}$ e após seis ciclos de recombinação ao acaso ("F8"), verificaram que, para o número de espigas, houve predominância dos efeitos aditivos nas duas gerações avaliadas $(\hat{\bar{d}}=0,48$ em $F_{2}$ e $\hat{\bar{d}}=0,39$ em "F"). Outros trabalhos, também utilizando o delineamento III, obtiveram estimativas similares (Robinson et al., 1949; Gardner et al., 1953; Moll et al., 1964; Wolf et al., 2000) em que houve predominância dos efeitos aditivos no controle da prolificidade. Wolf et al. (2000) obtiveram estimativa de herdabilidade entre média de progênies de 0,40 . 
Considerando o diâmetro da espiga, os trabalhos divergem quanto ao tipo de ação gênica predominante no controle do caráter. Na literatura, utilizando o delineamento III, são apresentadas estimativas do grau médio de dominância próximas a 1,00 e até superiores (Robinson et al., 1949; Gardner et al., 1953; Han \& Hallauer, 1989; Wolf et al., 2000). Deve-se salientar que estas estimativas foram obtidas a partir de populações $\mathrm{F}_{2}$, que podem fornecer estimativas viesadas da variância aditiva e de dominância. Utilizando populações com algumas gerações de recombinação ao acaso, os graus médios de dominância obtidos ficaram dentro do intervalo de 0,43 a 0,68 (Gardner \& Lonquist, 1959; Moll et al., 1964; Han \& Hallauer, 1989). Para o diâmetro da espiga, considerando 35 trabalhos, a variância aditiva foi, em média, cinco vezes superior à variância de dominância (Hallauer \& Miranda Filho, 1988). Estes trabalhos indicam que os efeitos aditivos são mais importantes que os efeitos de dominância no controle genético do diâmetro da espiga, porém os efeitos de dominância podem ser importantes dependendo do germoplasma avaliado. O diâmetro da espiga apresentou estimativa de herdabilidade média entre progênies de 0,75 em trabalho realizado por Wolf et al. (2000). Hallauer \& Miranda Filho (1988) apresentam um valor médio de herdabilidade obtido a partir de 35 trabalhos de 0,36 para o diâmetro da espiga.

Para o comprimento da espiga, considerando populações $F_{2}$, as estimativas de $\hat{\bar{d}}$ variaram de 0,80 a 1,76 (Gardner et al., 1953; Han \& Hallauer, 1989; Wolf et al., 2000). Estimativas de $\hat{\bar{d}}$ obtidas com populações de gerações avançadas de recombinação ao acaso, ficaram dentro do intervalo de 0,57 a 0,99 (Gardner \& Lonquist, 1959; Moll et al., 1964). Na revisão realizada por Hallauer \& Miranda Filho (1988), a variância aditiva foi cerca de três vezes superior à variância de dominância. VidalMartínez et al. (2001) estimaram os componentes de média a partir de linhagens exóticas e melhoradas, e obtiveram estimativas de $d$ (desvio do heretozigoto em relação à média) cerca de quatro vezes maior que a estimativa de $a$ (desvio do homozigoto em relação à média), tanto para a população formada de linhagens exóticas quanto para a população formada de linhagens melhoradas. Malvar et al. (1996) obtiveram estimativas de 
variâncias de dominância superior à variância aditiva em duas populações de milho da Espanha (Tuy e Ribadumia). Wolf et al. (2000) obtiveram estimativa de herdabilidade entre progênies de meios-irmãos de 0,65. Médias de estimativas de herdabilidade para o comprimento da espiga foi de 0,38 (Hallauer \& Miranda Filho, 1988). Os trabalhos que estudaram o controle genético do comprimento da espiga indicam que, tanto os efeitos de dominância quanto os aditivos são importantes no seu controle genético.

Para o caráter peso do grão as estimativas de componentes da variância genética são menos freqüente na literatura. Hallauer \& Miranda Filho (1988) relataram médias de estimativas de variância aditiva, variância de dominância e herdabilidade a partir de 11 trabalhos. A variância aditiva foi superior à variância de dominância em cerca de 3,7 vezes, e a média da herdabilidade entre parcelas foi de 0,42. Malvar et al. (1996) verificaram que a variância aditiva foi maior que a variância de dominância em duas populações avaliadas. Holthaus \& Lamkey (1995), estudando quatro populações de ciclos de seleção recorrente diferentes, obtiveram estimativas de variância aditiva superiores às da variância de dominância em todos ciclos de seleção recorrente. Apesar do pequeno número de trabalhos, há indícios de que a variância aditiva seja mais importante no controle genético deste caráter do que a variância de dominância.

Para o número de fileiras de grãos, Gardner et al. (1953) obtiveram estimativas de 0,43 e 0,67 para o grau médio de dominância em duas populações $F_{2}$ avaliadas. Wolf et al. (2000) encontrou estimativas semelhantes, 0,46, também utilizando populações $F_{2}$. Estimativas do grau médio de dominância encontradas por Han \& Hallauer (1989) em populações $\mathrm{F}_{2}$ e "F5", foram de 0,33 e 0,40, respectivamente. Os componentes de variância apresentados por Hallauer \& Miranda Filho (1988) mostram que a variância aditiva é superior à variância de dominância em mais de 10 vezes e a herdabilidade entre parcelas foi de 0,57. No trabalho de Holthaus \& Lamkey (1995), esta relação entre a variância aditiva e de dominância também apresentou valor similar. Vidal-Martínez et al. (2001), estimando os componentes de médias, verificaram efeitos significativos para $a$ e $d$, porém, os efeitos de dominância (d) foram superiores aos aditivos (a). Apesar disso, a 
maioria dos trabalhos indica a predominância dos efeitos aditivos no controle genético do número de fileiras de grãos.

Considerando o número de grãos por fileiras, apenas um trabalho relacionado ao controle genético foi encontrado. Vidal-Martínez et al. (2001) relataram que o componente $d$ foi significativo nas duas populações avaliadas, enquanto o componente $a$ foi significativo apenas na população originada de linhagens melhoradas, e as magnitudes dos efeitos de dominância foram bem superiores aos afeitos aditivos (a). Este resultado forneceu indícios que os efeitos de dominância podem ser preponderantes no controle genético do número de grãos por fileira. Porém, deve-se comentar novamente que as estimativas de componentes de médias podem ser influenciadas pelo cancelamento dos efeitos.

\subsubsection{Ramificações do pendão}

Outro caráter que apresenta uma associação com a produção de grãos além de fácil avaliação, é o número de ramificações do pendão. Geraldi et al. (1985) estudou alguns caracteres relacionados ao pendão (peso do pendão, comprimento e número de ramificações). Considerando a média de três populações, a correlação aditiva entre número de ramificações do pendão (RP) e produção de grãos (PG) mostrou-se negativa e de elevada magnitude, tendo sido altamente significativa $\left(\hat{r}_{a}=-0,65^{* *}\right)$. O número de ramificações do pendão apresentou herdabilidade média relativamente alta $\left(\hat{h}^{2}=0,46\right)$. De acordo com a revisão apresentada pelos autores, as possíveis causas da associação entre a produção de grãos e os caracteres do pendão são: i) em plantas com pendões menores, há menor competição por nutrientes com a inflorescência feminina, e/ou ii) o maior tamanho do pendão pode afetar o sombreamento nas folhas, diminuindo a área fotossintética, e conseqüentemente, reduzindo a produção de grãos. Esta última hipótese é mais evidenciada em semeaduras com maior densidade de plantio. Souza Júnior et al. (1985) estudaram a associação entre o número de ramificações do pendão (RP), produção de grãos (PG) e prolificidade (PROL). As estimativas de correlações aditivas entre estes 
caracteres foram $-0,44$ entre PG x RP, 0,99 entre PG x PROL, e $-0,65$ entre RP $\mathrm{x}$ PROL. Os autores estimaram também as correlações parciais entre os caracteres, e verificaram que a associação entre número de ramificações do pendão e a produção de grãos é expressa pela prolificidade. A partir destes resultados e de revisões de literatura a respeito da fisiologia da produção, os autores propuseram um mecanismo de controle destes caracteres. Este mecanismo se daria pelo AIA (Ácido Indol Acético), formado no pendão, que condiciona dominância apical e inibe o desenvolvimento da espiga. Conseqüentemente, a espiga superior irá se desenvolver após a redução dos níveis de AIA, causando assim o pronunciado efeito de protandria observado no milho. A espiga superior também produz AIA, inibindo o desenvolvimento das espigas inferiores. Para a prolificidade se expressar, precisa-se reduzir o tamanho do pendão, fato que diminui a produção de AIA, reduzindo a dominância apical. Como consequiência, as gemas axilares terão oportunidade de se diferenciar em espigas, dentro de um curto espaço de tempo, induzindo, assim, a coincidência da antese com a emergência dos estilos-estigmas, bem como a coincidência da emergência dos estilos-estigmas das espigas inferiores, fato que impediria a espiga superior de inibir o desenvolvimento das espigas inferiores.

Existem poucos trabalhos na literatura a respeito do controle genético do caráter número de ramificações do pendão. Mock \& Schuetz (1974) avaliaram as gerações P, $\mathrm{P}_{2}, \mathrm{~F}_{1}, \mathrm{~F}_{2}$ e $\mathrm{F}_{3}$ e concluíram que: i) o caráter é controlado por no mínimo oito genes; ii) os efeitos aditivos foram mais importantes que os de dominância; iii) as estimativas de herdabilidade entre plantas individuais foram em torno de 0,50 , indicando que a seleção para este caráter pode ser eficiente. Vidal-Martínez et al. (2001) também estimaram os componentes de médias do número de ramificações do pendão em dois cruzamentos de milho, um envolvendo linhagens exóticas e outro com linhagens elites. No cruzamento envolvendo linhagens exóticas, foi detectada significância apenas para os efeitos de dominância, enquanto que no cruzamento entre linhagens elites, os efeitos aditivos e de dominância mostraram-se significativos. As estimativas de herdabilidade encontradas para o caráter número de ramificações do pendão foram elevadas, entre 0,46 e 0,83, 
indicando que o caráter é pouco influenciado pelo ambiente (Geraldi et al., 1985; Souza Júnior et al., 1985).

\subsection{Delineamento III com marcadores moleculares}

Comstock \& Robinson $(1948,1952)$ apresentaram três delineamentos genéticos para obtenção de estimativas dos componentes da variância genética e do grau médio de dominância. No delineamento III, o material experimental utilizado é obtido pelo cruzamento de duas linhagens endogâmicas obtendo-se a geração $F_{1}$. Esta geração é autofecundada gerando a população $\mathrm{F}_{2}$, cujas plantas são retrocruzadas com as duas linhagens genitoras. São produzidas, então, pares de progênies retrocruzadas que são avaliadas em experimentos com repetições em vários ambientes. Este delineamento assume que as progênies devem ser uma amostra aleatória da população e desconsidera efeito materno. A partir das esperanças matemáticas dos quadrados médios das fontes de variação da análise da variância, estima-se a variância genética aditiva $\left(\sigma_{A}^{2}\right)$ e a variância genética de dominância $\left(\sigma_{D}^{2}\right)$. A fonte de variação de progênies fornece a estimativa da variância aditiva, já que representa a covariância de progênies de meios-irmãos $\left[\operatorname{Cov}_{M I}=(1 / 4) \sigma_{A}^{2}\right]$, e a fonte de variação da interação de progênies por linhagens genitoras fornece a estimativa da variância de dominância.

Considerando o uso de linhagens endogâmicas homozigóticas como genitoras, a variância aditiva é função somente dos efeitos aditivos, $\sigma_{A}^{2}=(1 / 2) \sum_{i} a_{i}^{2}$, e a variância de dominância assume a seguinte expressão $\sigma_{D}^{2}=(1 / 4) \sum_{i} d_{i}^{2}$, isso porque a frequiência dos locos segregantes é igual a 0,5 , sendo $a$ o desvio do homozigoto em relação a média, e $d$ o desvio do heterozigoto em relação a média. Algumas pressuposições são apresentadas por Comstock \& Robinson (1952) para interpretação dos componentes de variância genética, dentre elas a ausência de desequilíbrio de ligação e ausência de epistasia. Essas pressuposições são difíceis de serem obedecidas, já que, geralmente, este delineamento 
utiliza plantas da população $\mathrm{F}_{2}$ para obter as progênies retrocruzadas, onde $\mathrm{o}$ desequilíbrio de ligação é máximo, e o real efeito da epistasia no controle genético dos caracteres quantitativos é desconhecido. Apesar disso, as metodologias propostas por Comstock \& Robinson $(1948,1952)$ foram muito utilizadas em diversas espécies e forneceram informações importantes do controle genético de caracteres quantitativos. O desequilíbrio de ligação pode gerar viéses (covariâncias) nas estimativas de variância aditiva e de dominância. Para a variância aditiva, as estimativas ficam superestimadas quando os genes estão em fase de associação e subestimadas quando estão em fase de repulsão. A expressão da "variância aditiva" em populações em desequilíbrio de ligação é função da expressão $" \sigma_{A}^{2 n}=\sigma_{A}^{2} \pm 2(1-2 r) a_{1} a_{2}$, sendo $r$ a freqüência de recombinação entre os locos 1 e 2, e $a_{1}$ e $a_{2}$ os desvios dos homozigotos em relação à média dos locos 1 e 2, respectivamente, enquanto que a "variância de dominância" fica sempre superestimada, independente da fase de ligação dos genes que controlam o caráter, e sua expressão é a seguinte $" \sigma_{D}^{2} "=\sigma_{D}^{2}+2(1-2 r)^{2} d_{1} d_{2}$, sendo $d_{l}$ e $d_{2}$ os desvios dos heterozigotos em relação à média para os locos 1 e 2, respectivamente, para dois locos ligados. Estas covariâncias que surgem pelo desequilíbrio de ligação, podem contribuir para a ocorrência de estimativas de grau médio de dominância superiores a 1,00, causando o efeito de pseudo-sobredominância. Na literatura, estimativas do grau médio de dominância utilizando populações com gerações avançadas de recombinação, em que o desequilíbrio de ligação é desprezível, são inferiores às obtidas com populações $F_{2}$, indicando a ocorrência destes viéses (Gardner \& Lonquist, 1959; Moll et al., 1964; Han \& Hallauer, 1989; Dudley, 1994).

O delineamento III foi utilizado por diversos autores para o estudo do controle genético de caracteres de importância agronômica, principalmente em milho (Robinson et al., 1949; Gardner et al., 1953; Moll et al., 1964; Han \& Hallauer, 1989; Wolf et al., 2000; Silva, 2002). As informações geradas foram importantes para o entendimento do controle genético dos caracteres quantitativos. Porém, este delineamento estima o efeito conjunto dos genes que controlam o caráter. Com o advento de técnicas moleculares no início dos anos 70, vislumbrourse a possibilidade de se estudar o efeito de regiões 
cromossômicas associadas a caracteres de interesse, propiciando melhor entendimento dos genes que controlam estes caracteres (Edwards et al., 1987; Stuber et al., 1992). Cockerham \& Zeng (1996) propuseram a associação de marcadores moleculares com o delineamento III. Esta metodologia permite estimar os efeitos aditivos, dominantes e epistáticos dos QTLs associados aos marcadores moleculares, baseado em quatro contrastes ortogonais. Esses contrastes ortogonais são construídos com as médias fenotípicas das progênies agrupadas de acordo com os genótipos do marcador. Dois destes contrastes, $C_{1}$ e $C_{2}$, referem-se a diferença entre médias, e os outros dois, $C_{3}$ e $C_{4}$, referem-se a interação. Esta metodologia prevê que a genotipagem seja realizada nas plantas $F_{2}$ que deram origem às progênies retrocruzadas. $O$ primeiro contraste a ser estimado apresenta a seguinte expressão:

$$
\begin{gathered}
C_{1}=\bar{Y}_{M M(L 1)}+\bar{Y}_{M M(L 2)}-\bar{Y}_{m m(L 1)}-\bar{Y}_{m m(L 2)}, \text { ou seja, } \\
C_{1}=\bar{Y}_{M M}-\bar{Y}_{m m},
\end{gathered}
$$

em que $\bar{Y}_{M M(L 1)}$ refere-se a média fenotípica das progênies com genótipo marcador $M M$, retrocruzadas para a linhagem 1, os demais termos seguem a mesma lógica; o segundo contraste refere-se à diferença entre as médias das progênies associadas ao genótipo homozigótico e ao genótipo heterozigótico. A expressão é a seguinte:

$$
\begin{gathered}
C_{2}=\bar{Y}_{M M(L 1)}+\bar{Y}_{M M(L 2)}+\bar{Y}_{m m(L 1)}+\bar{Y}_{m m(L 2)}-2 \bar{Y}_{M m(L 1)}-2 \bar{Y}_{M m(L 2)}, \text { ou, } \\
C_{2}=\bar{Y}_{M M}+\bar{Y}_{m m}-2 \bar{Y}_{M m} ;
\end{gathered}
$$

o contraste 3 compara as médias das progênies homozigóticas para o marcador retrocruzadas para as linhagens genitoras. A expressão para esse contraste é:

$$
C_{3}=\bar{Y}_{M M(L 1)}-\bar{Y}_{m m(L 1)}-\bar{Y}_{M M(L 2)}+\bar{Y}_{m m(L 2)} ;
$$

o último contraste é realizado entre as médias fenotípicas das progênies homozigóticas para o marcador e heterozigóticas para um determinado marcador, retrocruzadas com as linhagens 1 e 2:

$$
C_{4}=\bar{Y}_{M M(L 1)}+\bar{Y}_{m m(L 1)}-2 \bar{Y}_{M m(L 1)}-\bar{Y}_{M M(L 2)}-\bar{Y}_{m m(L 2)}+2 \bar{Y}_{M m(L 2)}
$$


Considerando os valores genotípicos de um QTL (B) ligado ao marcador (Tabela, 1), os contrastes acima apresentados possuem os seguintes conteúdos genéticos (Cockerham \& Zeng, 1996):

$$
\begin{gathered}
C_{1}=2(1-2 r) a ; \\
C_{3}=2(1-2 r) d \mathrm{e} \\
C_{2}=C_{4}=0 .
\end{gathered}
$$

Tabela 1. Valores genotípicos das progênies retrocruzadas para as linhagens genitoras $\left(\mathrm{L}_{1}\right.$ e $\mathrm{L}_{2}$ ), considerando um QTL (gene B), para um determinado genótipo do marcador molecular.

\begin{tabular}{ccc}
\hline \multirow{2}{*}{ Genótipo do marcador } & \multicolumn{2}{c}{ Genótipo das linhagens genitoras $^{\mathbb{1}}$} \\
\cline { 2 - 3 } & $\mathrm{L}_{1}(\mathrm{BB})$ & $\mathrm{L}_{2}(\mathrm{bb})$ \\
\hline $\mathrm{MM}$ & $(1-r) B B+r B b$ & $(1-r) B b-r b b$ \\
$\mathrm{Mm}$ & $(B B+B b) / 2$ & $(B b+b b) / 2$ \\
$\mathrm{~mm}$ & $r B B+(1-r) B b$ & $r B b+(1-r) b b$ \\
\hline
\end{tabular}

Fonte: Cockerham \& Zeng (1996)

${ }^{/ 1} r$ refere-se à frequiência de recombinação entre o marcador e o QTL.

A partir das expressões dos contrastes, pode-se verificar que a identificação de um QTL associado a um marcador só é possível quando $r<(1 / 2)$. Esta metodologia considera o somatório dos efeitos de mais de um QTL ligado ao marcador, e, por isso os contrastes 1 e 3 passam a apresentar as seguintes expressões:

$$
\begin{gathered}
C_{i 1}=2 \sum_{i} c_{i j} a_{j} \mathrm{e} \\
C_{i 3}=2 \sum_{i} c_{i j} d_{j},
\end{gathered}
$$

assumindo $j$ o índice associado ao QTL, $i$ ao marcador e $c_{i j}=\left(1-2 r_{i j}\right)$.

Observando estes contrastes, verifica-se que pode haver um cancelamento dos efeitos genéticos, tanto aditivos quanto dominantes, já que estes podem ser bidirecionais. 
Porém, em espécies alógamas este cancelamento deve ocorrer com maior frequiência para os efeitos aditivos. Nestas espécies, geralmente, a depressão por endogamia é elevada, o que indica que grande parte dos efeitos de dominância são unidirecionais (Geraldi \& Vencovsky, 1980; Lima et al.; 1984; Nass, 1992; Cardoso, 1999; e outros).

Cockerham \& Zeng (1996) estenderam esta metodologia considerando também os efeitos epistáticos, isto é, quando mais de um QTL está associado a um marcador e interagem entre si. Com a inclusão dos efeitos epistáticos, os contrastes passam a apresentar os seguintes conteúdos genéticos:

$$
\begin{gathered}
C_{1}=2\left(1-2 r_{M B}\right)\left(a_{B}-\gamma / 2\right)+2\left(1-2 r_{M C}\right)\left(a_{C}-\phi / 2\right) ; \\
C_{2}=2 r_{B C}\left(1-2 r_{M B}\right)\left(1-2 r_{M C}\right)(\varepsilon+\omega) ; \\
C_{3}=2\left(1-2 r_{M B}\right)\left(d_{B}-\varepsilon / 2\right)+2\left(1-2 r_{M C}\right)\left(d_{C}-\varepsilon / 2\right) ; \\
C_{4}=2 r_{B C}\left(1-2 r_{M B}\right)\left(1-2 r_{M C}\right)(\phi+\gamma),
\end{gathered}
$$

em que $r_{M B}, r_{M C}$ e $r_{B C}$ referem-se às freqüências de recombinação entre o marcador $M \mathrm{e}$ o loco $B$ ou $C$, e entre os locos $B$ e $C$, respectivamente. Os efeitos epistáticos $\gamma, \phi, \varepsilon$ e $\omega$, representam os seguintes tipos de epistasia:

$$
\begin{aligned}
& \gamma=a_{C} d_{B}, \text { epistasia dominante por aditivo (axd); } \\
& \phi=a_{B} d_{C}, \text { epistasia aditivo por dominante (dxa); } \\
& \varepsilon=a_{B} a_{C}, \text { epistasia aditiva por aditiva (axa); } \\
& \omega=d_{B} d_{C}, \text { epistasia dominante por dominante (dxd), }
\end{aligned}
$$

sendo $a_{B}$ e $a_{C}$ os efeitos aditivos associados aos locos $B$ e $C$, respectivamente, e $d_{B}$ e $d_{C}$ os efeitos de dominância associados aos locos $B$ e $C$, respectivamente.

Considerando agora os efeitos epistáticos, pode-se notar que o contraste 1 estima os efeitos aditivos além de parte da epistasia aditivo por dominante $(\gamma)$ e dominante por aditivo $(\phi)$, e o contraste 3 estima os efeitos de dominância e parte dos efeitos epistáticos aditivo por aditivo $(\varepsilon)$ associados aos QTLs. O contraste 2 estima a 
epistasia aditiva por aditiva $(\varepsilon)$ e dominante por dominante $(\omega)$, enquanto que o contraste 4, estima a epistasia aditiva por dominante $(\phi)$ e dominante por aditiva $(\gamma)$.

Os autores sugerem que, para a análise dos dados, estes contrastes sejam transformados em coeficientes de regressão parcial. Para isso, utiliza-se a seguinte expressão $\beta_{C}=C_{C} / \sum_{1}^{4,6} X_{t}^{2}$, em que $\sum_{1}^{4,6} X_{t}^{2}$, refere-se ao somatório ao quadrado dos coeficientes que incidem sob as médias fenotípicas de cada contraste $C_{c}$. Para cada contraste têm-se:

$$
\begin{aligned}
& \beta_{1}=C_{1} / 4 ; \\
& \beta_{2}=C_{2} / 12 ; \\
& \beta_{3}=C_{3} / 4 \mathrm{e} \\
& \beta_{4}=C_{4} / 12 .
\end{aligned}
$$

A interpretação destes coeficientes de regressão é a mesma dos contrastes, isto é, a significância dos contrastes 1 e 3 indicam que o (s) QTL (s) ligado (s) àquele marcador apresenta $(\mathrm{m})$ principalmente efeitos aditivos e dominantes, respectivamente. A significância dos contrastes 2 e 4, indicam que existe mais de um QTL ligado aquele marcador e que eles interagem entre si (epistasia). Deve-se salientar que a não significância dos contrastes 2 e 4 indicam apenas que não ocorre epistasia entre os QTLs ligados ao marcador.

Outro fato importante enfatizado por Cockerham \& Zeng (1996) é que os contrastes 2 e 4 conseguem captar apenas parte dos efeitos epistáticos. O máximo valor da expressão $r_{B C}\left(1-2 r_{M B}\right)\left(1-2 r_{M C}\right)$ é $1 / 8$ quando o marcador $M$ estiver entre o QTL $B$ e $C$ e $r_{B C}=1 / 4$. Então $\beta_{2}$ e $\beta_{4}$ estimam, no máximo, 1/48 dos efeitos epistáticos. Assim, considera-se que esta metodologia é conservadora na estimação dos efeitos epistáticos.

$\mathrm{Na}$ literatura, há somente dois trabalhos que utilizaram a metodologia do delineamento III associada a marcadores moleculares: Cockerham \& Zeng (1996) e Silva (2002). O trabalho de Cockerham e Zeng (1996) utilizou os dados obtidos por Stuber et al. (1992). A análise realizada por Stuber et al. (1992) teve por objetivo comparar duas 
metodologias de mapeamento de QTLs, a análise de marca simples e o mapeamento por intervalo. Para tanto, usaram 264 progênies $F_{3}$ retrocruzadas com ambas linhagens genitoras, B73 e Mo17. Os caracteres avaliados foram: produção de grãos, prolificidade, altura da espiga, altura da planta, florescimento masculino, teor de umidade nos grãos e área da folha da espiga. Para a produção de grãos, não foi verificada diferença entre os dois métodos de mapeamento, exceto no cromossomo 6. Para os demais caracteres avaliados, detectaram-se poucos QTLs. Com relação aos efeitos genéticos dos QTLs detectados, os autores comentam que para a produção de grãos, os genótipos heterozigóticos tiveram rendimento superior aos homozigóticos, indicando a presença de sobredominância ou pseudo-sobredominância, e que os QTLs detectados contribuíram com a heterose, exceto para um QTL. Esta hipótese foi reforçada pela alta correlação entre a produção de grãos e marcadores heterozigóticos. Apesar das progênies terem sido avaliadas em seis ambientes, foi detectada pequena interação entre QTLs e ambientes.

Cockerham \& Zeng (1996) aplicaram a metodologia por eles proposta aos dados de Stuber et al. (1992), salientando que a principal finalidade desta metodologia é o estudo dos efeitos dos QTLs e não especificamente o mapeamento dos mesmos. Apesar disso, esta análise permite, a partir das marcas, localizar os QTLs em grupos de ligação e verificar se estão concentrados em determinados cromossomos ou espalhados pelo genoma da espécie. A análise para produção de grãos revelou que para a maioria dos marcadores foram detectados QTLs com efeitos significativos de dominância $\left(\hat{\beta}_{3}\right)$ e que estes apresentaram sinais positivos. QTLs com efeitos aditivos significativos $\left(\hat{\beta_{1}}\right)$ foram detectados em menor proporção e se localizaram, principalmente, nos cromossomos 3 e 4. Nestes cromossomos, os efeitos aditivos significativos foram em sua maioria positivos, nos demais cromossomos houve uma variação dos sinais dos coeficientes $\hat{\beta}_{1}$, porém estes não foram significativos. Considerando os coeficientes $\hat{\beta_{2}}$ e $\hat{\beta_{4}}$, que quantificam a epistasia, foi observado um número expressivo de marcadores associados a QTLs com estes efeitos, haja vista que esta metodologia é conservadora na detecção de efeitos epistáticos. A interação genótipos por ambientes mostrou-se pouco importante, já que 
foram detectados poucos marcadores associados a QTLs que interagiram com ambientes. Na análise realizada por Stuber et al. (1992), foi obtido resultado semelhante.

Resultados semelhantes foram obtidos nas análises realizadas para os caracteres de altura da espiga e altura da planta. Foram detectados QTLs em todos os cromossomos, sendo que o maior número de coeficientes significativos foi obtido para $\hat{\beta_{1}}$, seguidos dos coeficientes $\hat{\beta}_{3}$. Os efeitos epistáticos $\left(\hat{\beta}_{2}\right.$ e $\left.\hat{\beta}_{4}\right)$ foram detectados em menor número, fato também verificado para interação dos coeficientes com ambientes.

Para a área da folha da espiga foram detectados muitos marcadores associados a QTLs de efeitos aditivos, sendo obtidas proporções semelhantes entre coeficientes positivos e negativos. Marcadores associados a QTLs de efeitos dominantes também foram encontrados com muita freqüência, mas de sinais positivos. A análise do florescimento masculino revelou QTLs de efeitos aditivos e dominantes em vários cromossomos, sendo os de efeitos dominantes, em grande parte, de sinal negativo. Isto é, dominância para a precocidade. Este caráter apresentou ainda, um grande número de marcadores que interagiram com os ambientes para todos os efeitos, indicando que os efeitos destes QTLs são muito influenciados pelas condições ambientais. Para o teor de umidade nos grãos detectaram-se poucos QTLs. Os coeficientes $\hat{\beta}_{1}$ e $\hat{\beta}_{2}$ interagiram mais com os ambientes que os demais coeficientes. O fato de poucos QTLs terem sido detectados para este caráter pode ser atribuído à baixa variabilidade do mesmo na população estudada. A análise do caráter número de espigas mostrou marcadores associados a QTLs de efeitos aditivos e dominantes na maioria dos cromossomos. Além disso, detectou-se interação com ambientes para QTLs de efeitos aditivos e dominantes, principalmente no cromossomo 3.

As linhagens adotadas por Stuber et al. (1992), B73 e Mo17, são bem contrastantes entre si e o híbrido entre elas apresenta elevado potencial produtivo. Conseqüentemente, é de se esperar que cada linhagem possua um conjunto gênico favorável para produção de grãos. Nesta análise, o sinal negativo indica que os alelos favoráveis são provenientes da linhagem Mo17 e o sinal positivo da linhagem B73. Para 
o coeficiente $\hat{\beta}_{1}$, nos cromossomos 3 e 4 , houve predominância de efeitos positivos, enquanto nos demais cromossomos houve uma distribuição homogênea dos efeitos, no que diz respeito ao sinal. A falta de significância para muitos $\hat{\beta_{1}}$ 's pode ter sido devida ao cancelamento dos efeitos aditivos.

Uma das hipóteses que podem auxiliar na explicação da heterose, é a ocorrência de epistasia (interação entre genes). O trabalho de Cockerham \& Zeng (1996) evidenciou que os efeitos relacionados aos coeficientes $\hat{\beta_{2}}$ e $\hat{\beta_{4}}$, não são desprezíveis e podem contribuir para o vigor híbrido observado. O efeito de dominância dos alelos, também é cogitado para explicar o fenômeno da heterose. Os resultados obtidos pelos autores são concordantes com esta hipótese. A questão paira sobre a ocorrência de sobredominância. Como um marcador pode estar ligado a outros QTLs, este marcador pode estar representando um conjunto de QTLs com efeito de dominância. Como para os efeitos de dominância a variação dos sinais foi menor que a variação ocorrida para os efeitos aditivos, o cancelamento pode ter sido maior para os efeitos aditivos, por conseguinte, gerando o aparecimento de pseudo-sobredominância. Porém, isto não exclui a hipótese de sobredominância.

O outro trabalho utilizando o delineamento III com marcadores moleculares, foi realizado por Silva (2002). Este autor utilizou germoplasma de origem tropical e avaliou dez caracteres em milho. Foram avaliadas 250 progênies $\mathrm{F}_{2: 3}$ retrocruzadas para ambas linhagens genitoras, avaliadas em seis ambientes. O mapa genético foi construído com 140 marcadores do tipo microssatélites. O autor obteve 43\%, 11\%, 71\% e $25 \%$ dos marcadores associados a QTLs com coeficientes $\hat{\beta_{1}}, \hat{\beta_{2}}, \hat{\beta_{3}}$ e $\hat{\beta_{4}}$ significativos, respectivamente. Considerando ainda o efeito dos coeficientes em módulo, observou-se que os efeitos de dominância foram mais importantes no controle genético da produção de grãos seguidos pelos efeitos aditivos e epistáticos. A interação com ambientes foi pequena, sendo que apenas $7 \%$ dos marcadores apresentaram algum tipo de efeito genético associado interagindo com ambientes. 
Os caracteres altura da espiga e altura da planta apresentaram resultados similares quanto à significância de marcadores associados a QTLs. Para estes caracteres, o número de marcadores associados a QTLs com efeito de dominância $\left(\hat{\beta}_{3}\right)$ foi superior aos epistáticos $\left(\hat{\beta_{2}}\right.$ e $\left.\hat{\beta_{4}}\right)$, e aditivos $\left(\hat{\beta_{1}}\right)$. Porém, em módulo, a magnitude dos efeitos aditivos foi superior aos de dominância e aos epistáticos. Para a posição relativa da espiga, detectou-se um maior número de marcadores associados aos efeitos aditivos $\left(\hat{\beta_{1}}\right)$, seguidos pelos epistáticos $\left(\hat{\beta_{2}}\right.$ e $\left.\hat{\beta_{4}}\right)$ e dominantes $\left(\hat{\beta_{3}}\right)$. Considerando os valores dos coeficientes em módulo, verificourse que os efeitos aditivos foram mais expressivos que os epistáticos e os dominantes. Com relação a interação com ambientes, verificou-se que para altura da planta e altura da espiga, 11\% dos marcadores apresentaram algum efeito genético associado significativo que interagiu com ambientes, e para a posição relativa da espiga, cerca de 16\% dos marcadores estiveram associados a coeficientes significativos que interagiram com ambientes (Silva, 2002).

Este autor avaliou também caracteres relacionados ao florescimento: florescimento masculino (FM), feminino (FF) e intervalo de florescimento (IF). Considerando a porcentagem de marcadores associados aos coeficientes $\hat{\beta_{1}}, \hat{\beta_{2}}, \hat{\beta}_{3}$ e $\hat{\beta_{4}}$ significativos, verificou-se resultados semelhantes entre estes caracteres. Para o coeficiente $\hat{\beta_{1}}$, a percentagem de marcadores associados foi de $56 \%$, $44 \%$ e $22 \%$, para FF, FM e IF, respectivamente. Considerando $\hat{\beta}_{2}$, as percentagens de marcadores associados foram de 31\%, 29\% e $10 \%$ para FF, FM e IF, respectivamente. Para $\hat{\beta}_{3}$, a percentagem de marcadores associados foi de 38\% para FF, 38\% para FM e 15\% para IF. O coeficiente $\hat{\beta}_{4}$ foi significativo para $17 \%$ dos marcadores associados a QTLs de FF, $17 \%$ de FM e $6 \%$ de IF. Os valores em módulo dos efeitos também apresentaram resultados similares, em que, os efeitos aditivos foram superiores aos dominantes e aos epistáticos. A interação com ambientes foi pequena para florescimento masculino e 
feminino, e para o intervalo de florescimento $11 \%$ de marcadores estiveram associados a QTLs com algum efeito interagindo com ambientes.

Para o número de folhas acima da espiga superior, Silva (2002) verificou que os valores em módulo dos coeficientes mostraram maior importância dos efeitos aditivos seguidos pelos efeitos de dominância e epistáticos. Resultado semelhante foi verificado para o caráter umidade do grão, que apresentou 72 (51\%) marcadores associados a pelo menos um coeficiente significativo, além de maior número de marcadores associados a QTLs com efeito aditivo $\left(\hat{\beta_{1}}\right)$.

Silva (2002) verificou que, para os caracteres avaliados, as linhagens adotadas foram bem contrastantes e os QTLs se encontram distribuídos por todo genoma do milho. Em concordância com o trabalho de Cockerham \& Zeng (1996), observou-se que os efeitos de dominância foram mais expressivos que os demais para a produção de grãos. Foi verificado também, que os efeitos epistáticos podem ser importantes no controle genético dos caracteres avaliados, uma vez que esta metodologia é conservadora na detecção destes efeitos. Cockerham \& Zeng (1996) detectaram 42\% de marcadores associados a coeficientes com algum efeito epistático $\left(\hat{\beta}_{2}\right.$ e/ou $\left.\hat{\beta}_{4}\right)$ para $\mathrm{PG}$, enquanto Silva (2002) encontrou 32\% de marcadores associados a coeficientes com algum efeito epistático $\left(\hat{\beta}_{2}\right.$ e/ou $\left.\hat{\beta_{4}}\right)$ para este caráter.

Em ambas pesquisas, a ocorrência de coeficientes $\hat{\beta}_{2}$ significativos foi menor que a de $\hat{\beta}_{4}$ significativos, lembrando que $\hat{\beta}_{2}$ está associada a detecção de efeitos epistáticos aditivo $\mathrm{x}$ aditivo e dominante $\mathrm{x}$ dominante, enquanto $\hat{\beta}_{4}$ está relacionada à detecção de efeitos epistáticos aditivo $\mathrm{x}$ dominante e dominante $\mathrm{x}$ aditivo. $\mathrm{Na}$ análise realizada por Cockerham \& Zeng (1996) não foi detectado coeficiente associado a efeito epistático apenas no cromossomo 7, enquanto Silva (2002) detectou efeitos epistáticos em todos os cromossomos do milho. 


\section{MATERIAL E MÉTODOS}

\subsection{Material genético}

As linhagens genitoras utilizadas foram L-14-04B $\left(\mathrm{S}_{5}\right)$ e L-08-05F $\left(\mathrm{S}_{7}\right)$, ambas provenientes do Programa de Melhoramento de Milho do Departamento de Genética USP/ESALQ, e apresentam grande diversidade genética para diversos caracteres de importância agronômica e boa capacidade especifica de combinação.

A linhagem L-08-05F apresenta grãos duros de coloração alaranjada e foi extraída da população IG-1, a qual foi sintetizada no Departamento de Genética da USP/ESALQ. A linhagem L-14-04B foi obtida da população BR-106 e apresenta grãos dentados amarelos. A população IG-1 foi formada a partir do cruzamento do híbrido intervarietal das populações BR-105 e EPB-5 com o macho do híbrido duplo BR-201. A população BR-106 foi sintetizada pelo Centro Nacional de Pesquisa de Milho e Sorgo da EMBRAPA. Essas populações foram formadas com a utilização de germoplasma de origem tropical. Souza Júnior et al. (1993) relataram que o cruzamento entre as populações IG-1 e BR-106, as quais pertencem a grupos heteróticos distintos, apresenta elevada magnitude de heterose.

$\mathrm{Na}$ área experimental do Departamento de Genética USP/ESALQ, foi realizado o cruzamento entre as linhagens L-08-05F e L-14-04B para obter a geração $\mathrm{F}_{1}$. A obtenção da geração $F_{2}$ foi realizada autofecundando-se plantas da geração $F_{1}$. Visando a obtenção de um maior número de sementes para avaliação em diversos ambientes em experimentos com repetições, 250 plantas $F_{2}$ foram autofecundadas, dando origem a progênies $F_{2}: 3$. A obtenção das progênies retrocruzadas com cada genitor foi realizada em dois campos isolados, um para cada linhagem genitora. Semearam-se 30 sementes de 
cada progênie em uma linha de $6,00 \mathrm{~m}$, com espaçamento de $0,80 \mathrm{~m}$ entre linhas. A linhagem genitora utilizada como macho foi semeada a cada duas linhas de progênies. Antes do florescimento masculino, as progênies foram despendoadas, deixando em cada campo isolado somente pólen das linhagens genitoras masculinas. Para obter maior sincronismo entre o florescimento das linhagens genitoras e das progênies, semeourse as linhagens genitoras em três épocas distintas: $1^{\mathrm{a}}$ ) cinco dias antes da semeadura das progênies; $2^{\underline{a}}$ ) simultaneamente com a semeadura das progênies; $3^{\underline{a}}$ ) cinco dias após a semeadura das progênies. As espigas de uma mesma progênie foram colhidas em conjunto, debulhadas e as sementes misturadas. Estas sementes foram utilizadas na semeadura dos experimentos com repetições em vários ambientes.

\subsection{Métodos}

Este trabalho foi dividido em duas etapas. No Departamento de Genética da USP/ESALQ, foram realizadas a obtenção do material genético e a condução dos experimentos. No Laboratório de Biologia Molecular e Engenharia Genética (CEBMEG) do Instituto de Biologia da UNICAMP, foram realizadas as amplificações e genotipagem das plantas $F_{2}$, que deram origem as progênies $F_{2: 3}$. A seguir serão descritos os procedimentos adotados neste trabalho.

\subsubsection{Delineamento III}

Este delineamento foi proposto por Comstock \& Robinson $(1948,1952)$ com o objetivo de estimar os componentes de variância genética e o grau médio de dominância dos genes que controlam um caráter quantitativo. $\mathrm{O}$ material experimental proposto por estes autores é formado pelas progênies de retrocruzamento de plantas $F_{2}$ com as linhagens genitoras. Após a mensuração dos dados, procede-se a análise de variância para o (s) cara(c)ter(es) de interesse (Tabela 2). Observe-se que nesta análise a fonte de variação de linhagens é fixa, enquanto a de plantas $\mathrm{F}_{2}$ e a da interação são aleatórias. 
Tabela 2. Resumo da análise da variância do delineamento III avaliado em um local com as respectivas esperanças matemáticas das fontes de variação de interesse.

\begin{tabular}{lcll}
\hline FV & GL & QM & E(QM) $)^{1 /}$ \\
\hline Linhagens & 1 & & \\
Plantas F2 & $\mathrm{n}-1$ & $\mathrm{QM}_{1}$ & $\sigma^{2}+2 r \sigma_{m}^{2}$ \\
Plantas F $F_{2}$ Linhagens & $\mathrm{n}-1$ & $\mathrm{QM}_{2}$ & $\sigma^{2}+r \sigma_{m l}^{2}$ \\
Resíduo & & $\mathrm{QM}_{3}$ & $\sigma^{2}$ \\
\hline
\end{tabular}

${ }^{11} \sigma^{2}$ é a variância do resíduo, $\sigma_{m l}^{2}$ é a variância de progênies originária da interação dos genótipos das plantas $\mathrm{F}_{2}$ com as linhagens genitoras, $\boldsymbol{\sigma}_{m}^{2}$ é a variância de progênies originária das diferenças genéticas entre as plantas $\mathrm{F}_{2}$, $r$ é o número de repetições, $n$ é o número de plantas $\mathrm{F}_{2}$ avaliadas.

Geneticamente, têm-se que:

$$
\begin{gathered}
\sigma_{m}^{2}=\frac{1}{4} \sigma_{A}^{2} \text { e } \hat{\sigma}_{A}^{2}=4 \hat{\sigma}_{m}^{2}, \\
\sigma_{m l}^{2}=\sigma_{D}^{2} \text { e } \hat{\sigma}_{D}^{2}=4 \hat{\sigma}_{m l}^{2},
\end{gathered}
$$

e o grau médio de dominância $(\bar{d})$ é estimado por:

$$
\hat{\bar{d}}=\sqrt{\frac{2 \hat{\sigma}_{D}^{2}}{\hat{\sigma}_{A}^{2}}}=\sqrt{\frac{\sum \hat{d}^{2}}{\sum \hat{a}^{2}}}
$$

sendo, $\hat{\sigma}_{A}^{2}$ a estimativa da variância aditiva e $\hat{\sigma}_{D}^{2}$ a estimativa da variância de dominância.

Neste trabalho, ao invés de plantas $\mathrm{F}_{2}$, como proposto no trabalho original, foram adotadas progênies $F_{2: 3}$. Esta modificação foi utilizada com o intuito de obter maior número de sementes das progênies retrocruzadas para avaliação em experimentos com repetições em diversos ambientes. 


\subsubsection{Extração de DNA e genotipagem}

Para a genotipagem, foram coletadas uma ou duas folhas das plantas $F_{2}$ que deram origem às progênies $F_{2: 3}$. Estas folhas foram acondicionadas em sacos de sombrite e armazenadas em recipiente com gelo e transportadas para o laboratório CEBMEG/UNICAMP. No mesmo dia, estas folhas foram congeladas em nitrogênio líquido à $-70^{\circ} \mathrm{C}$. Posteriormente, realizou-se a liofilização e moagem das amostras, as quais foram armazenadas em frascos específicos e congeladas à $-20^{\circ} \mathrm{C}$.

A extração de DNA foi realizada adotando a metodologia desenvolvida por Hoisington et al. (1994). Para isso, foram realizadas duas extrações sucessivas em clorofórmio/álcool, visando maior pureza da amostra final, utilizando-se $50 \mathrm{mg}$ de tecido liofilizado e tampão de extração CTBA (Mixed alkyltrimethyl-ammonium bromide).

Para genotipagem das 250 plantas $\mathrm{F}_{2}$ foram testados 859 primers de microssatélites, sendo que destes, apenas 140 marcadores apresentaram polimorfismo, boa visualização e amplificação, além de segregação 1:2:1 adotando o critério de Bonferroni. O programa de amplificação adotado neste trabalho foi descrito por Silva (2002). A sequiência dos primers de microssatélites adotadas neste trabalho foi obtida na homepage PCR Primers Pairs of Microsatellites da Universidade de Missouri-Columbia (http://nucleus.agron.missouri.edu/).

\subsubsection{Mapa genético}

O mapa genético adotado na análise do delineamento III foi construído utilizando o programa Mapmaker v.3.0 (Lincoln et al., 1992). Para isso, foram selecionados 140 marcadores moleculares que não apresentaram desvios significativos de segregação de 1:2:1. Adotou-se o critério de Bonferroni para testar os desvios de segregação. Este critério é adotado quando há necessidade de obter um nível de significância conjunto para testes múltiplos (Sokal \& Rohlf, 1995). Ele pressupõe que os testes sejam independentes, o que não ocorre quando os marcadores estão no mesmo 
cromossomo. O mapa genético adotado neste trabalho foi construído por Silva (2002) e é apresentado na Figura 1.

\subsubsection{Condução experimental}

Neste tópico estão descritos o delineamento experimental adotado, os caracteres avaliados e analisados e os ambientes avaliados em que os experimentos foram conduzidos. Esta etapa foi realizada na Escola Superior de Agricultura "Luiz de Queiroz"/USP.

\subsubsection{Delineamento experimental e ambientes de avaliação}

As 500 progênies retrocruzadas utilizadas neste trabalho foram divididas em cinco experimentos em látices simples 10x10. Cada experimento foi constituído por 50 progênies retrocruzadas para ambas linhagens genitoras, perfazendo um total de 100 progênies por látice. $\mathrm{Na}$ instalação dos experimentos no campo, delimitoutse a área experimental e nesta área foram sorteados os experimentos e as repetições. Dessa forma, os cinco experimentos foram instalados em uma mesma área (adjacentes) com as repetições alocadas conforme o sorteio.

O conjunto de cinco experimentos foi conduzido em dois anos agrícolas e em diferentes épocas de semeadura. Cada combinação entre anos agrícolas e épocas de semeadura foi considerada como um ambiente distinto, perfazendo um total de seis ambientes:

Ambiente 1: Estação Experimental do Departamento de Genética (E.E.LGN), ano agrícola 1999/2000, semeado em dezembro de 1999;

Ambiente 2: E.E.LGN, ano agrícola de 2000/2001, semeado em outubro de 2000;

Ambiente 3: E.E.LGN, ano agrícola de 2000/2001, semeado em novembro de 2000; 
Ambiente 4: Estação Experimental Fazenda Areão, ano agrícola de 2000/2001, semeado em dezembro de 2000;

Ambiente 5: Estação Experimental Fazenda Caterpillar, ano agrícola de 2000/2001, semeado em novembro de 2000;

Ambiente 6: E.E.LGN, ano agrícola 2000/2001, semeado em janeiro de 2001.

Todas as estações experimentais pertencem a Escola Superior de Agricultura "Luiz de Queiroz" e estão localizadas no município de Piracicaba - SP.

Na Estação Experimental do Departamento de Genética foi instalado sistema de irrigação, acionado sempre que necessário. Os tratos culturais seguiram as recomendações técnicas de cada ambiente.

Cada parcela foi constituída de uma linha de 4,00 m, com espaçamento de 0,80 m entre linhas. No momento da semeadura, foram distribuídas 40 sementes e após 30 dias foi realizado o desbaste, deixando 20 plantas competitivas na parcela a cada 0,20 m. Esta densidade de semeadura proporciona um estande médio de 62.500 plantas $\mathrm{ha}^{-1}$.

\subsubsection{Caracteres avaliados e analisados}

Para o estudo dos componentes da produção em milho, foram tomados dados na parcela e dados da espiga. Na parcela, coletaram-se os seguintes dados: produção de grãos (PG), em kg parcela ${ }^{-1}$, posteriormente ajustados para $15 \%$ de umidade dos grãos e estande médio dos experimentos; número de plantas da parcela no momento da colheita (estande); umidade dos grãos, mensurada em amostras retiradas de cada parcela, utilizando um determinador eletrônico (Dickey-John); peso de 500 grãos em gramas (P500); número de ramificações do pendão (RP), coletadas de cinco plantas competitivas da parcela; número de espigas da parcela, coletado para estimar a prolificidade (PROL), que é fornecida pela razão entre o número de espigas e o estande da parcela, que para análise foi ajustado pelo estande médio. Saliente-se que o número de espigas da parcela não é dado pelo número total de espigas da parcela, mas pelo número de espigas normais 
na parcela, sendo que se realiza um agrupamento das espigas pequenas para formar uma espiga normal.

Os caracteres avaliados na espiga foram medidos em uma amostra de cinco espigas sadias por parcela. Os caracteres avaliados foram: diâmetro da espiga (DE), em cm; comprimento da espiga $(\mathrm{CE})$, em $\mathrm{cm}$; número de grãos por fileira $(\mathrm{NGF})$ e número de fileiras da espiga (NFI).

Os caracteres de RP, DE, CE, NFI e NGF foram analisados utilizando a média de cinco observações de cada parcela. Com exceção de P500, que foi coletado nos cinco ambientes avaliados no agrícola de 2000/2001, os demais caracteres foram avaliados nos seis ambientes.

\subsubsection{Análises estatístico-genéticas}

Inicialmente foram realizadas as análises de variância dos caracteres avaliados para cada látice 10x10 de acordo com o seguinte modelo matemático:

$$
Y_{i j k l}=\mu+b_{k(l)}+r_{l}+p_{i}+g_{j}+p g_{i j}+e_{i j k l}
$$

em que:

$Y_{i j k l}$ : refere-se à observação da progênie $i$, retrocruzada com a linhagem genitora $j$, alocada na repetição $l$, no bloco $k$.

$\mu$ : média;

$b_{k(l)}$ : efeito do bloco incompleto $k$, dentro da repetição $l, k=1, \ldots, 10$;

$r_{l}$ : efeito da repetição $l, l=1,2$;

$p_{i}$ : efeito da progênie $i, i=1, \ldots, 50$

$g_{j}:$ efeito da linhagem genitora $j, j=1,2$;

$p g_{i j}$ : efeito da interação entre progênies e linhagens genitoras;

$e_{i j k l}$ : erro associado à observação $Y_{i j k l}$; 
Posteriormente, foram realizadas as análises agrupadas por ambiente, considerando os cinco experimentos. O modelo matemático utilizado foi:

$$
Y_{i j k l m}=\mu+s_{m}+b_{k(l m)}+r_{l(m)}+p_{i(m)}+g_{j(m)}+p g_{i j(m)}+e_{i j k l m}
$$

em que:

$Y_{i j k l m}$ : refere-se à observação da progênie $i$, retrocruzada com a linhagem genitora $j$, alocada na repetição $l$, no bloco $k$, dentro do experimento $m$;

$\mu$ : média;

$s_{m}$ : efeito do experimento $m, m=1, \ldots, 5$;

$b_{k(l m)}$ : efeito do bloco incompleto $k$, dentro da repetição $l$ e experimento $m$, $k=1, \ldots, 10$

$r_{l(m)}$ : efeito da repetição $l$, dentro do experimento $m, l=1,2$;

$p_{i(m)}$ : efeito da progênie $i$, dentro do experimento $m, i=1, \ldots, 250$;

$g_{j(m)}$ : efeito da linhagem genitora $j$, dentro do experimento $m, j=1,2$;

$p g_{i j(m)}$ : efeito da interação de progênies e linhagens genitoras, dentro de experimentos;

$e_{i j k l m}$ : erro associado à observação $Y_{i j k l m} ;$

A seguir foram realizadas as análises conjuntas agrupadas cujo modelo matemático utilizado é:

$$
\begin{aligned}
& Y_{i j k l m n}=\mu+a_{n}+s_{m}+a s_{m n}+b_{k(l m m)}+r_{l(m n)}+p_{i(m)}+g_{j(m)}+p g_{i j(m)}+p a_{i n(m)} \\
& +g a_{j n(m)}+p g a_{i j n(m)}+e_{i j k l m n}
\end{aligned}
$$

em que:

$Y_{i j k l m n}$ : observação da progênie $i$, retrocruzada com a linhagem genitora $j$, alocada na repetição $l$, no bloco $k$, dentro do experimento $m$ e avaliada no ambiente $n$; 
$\mu$ : média;

$a_{n}$ : efeito do ambiente $n, n=1, \ldots, 6$, exceto para P500, em que $n=1, \ldots, 5$;

$s_{m}$ : efeito do experimento $m, m=1, \ldots, 5$;

$a s_{m n}$ : efeito da interação entre ambientes e experimentos;

$\mathrm{b}_{\mathrm{k}(\mathrm{Imn})}$ : efeito do bloco incompleto $k$, dentro da repetição $l$, alocada no experimento $m$ e ambiente $n, k=1, \ldots, 10$;

$r_{l(m n)}$ : efeito da repetição $l$, dentro do experimento $m$ e ambiente $n, l=1,2$;

$p_{i(m)}:$ efeito da progênie $i$, dentro do experimento $m, i=1, \ldots, 250$

$g_{j(m)}$ : efeito da linhagem genitora $j$, dentro do experimento $m, j=1,2$;

$p g_{i j(m)}$ : efeito da interação de progênies e linhagens genitoras, dentro de experimentos;

$p a_{i n(m)}$ : efeito da interação de progênies e ambientes, dentro de experimentos;

$g a_{j n(m)}$ : efeito da interação de linhagens genitoras e ambientes dentro de experimentos;

$p g a_{i j n(m)}$ : efeito da interação entre progênies, linhagens genitoras e ambientes dentro de experimentos;

$e_{i j k l m n}$ : erro associado à observação $Y_{i j k l m n}$;

Nestas análises, todas as fontes de variação foram consideradas aleatórias, exceto a de linhagens genitoras (Tabela 3). As análises de variância foram realizadas utilizando o PROC GLM do SAS ${ }^{\circledR}$ (SAS Institute, 1999). 
Tabela 3. Resumo da análise de variância e teste F, com as respectivas esperanças matemáticas dos quadrados médios das fontes de variação da análise conjunta agrupada utilizando o delineamento III.

\begin{tabular}{lcccc}
\hline Fonte variação & $\mathrm{GL}$ & $\mathrm{QM}$ & $\mathrm{E}(\mathrm{QM})$ & $\mathrm{F}$ \\
\hline Ambientes (A) & $\mathrm{a}-1$ & & & \\
Experimentos (E) & $\mathrm{s}-1$ & & & \\
Repetições (R)/E/A & $\mathrm{as}(\mathrm{r}-1)$ & & & \\
Blocos/R/E/A & $\mathrm{rsa}(\mathrm{k}-1)$ & & & \\
Genitor/E & $\mathrm{s}$ & & & \\
Genitor x A/E & $\mathrm{s}(\mathrm{a}-1)$ & & $Q M_{p} / Q M_{p a}$ \\
Progênies/E & $\mathrm{s}(\mathrm{p}-1)$ & $Q M_{p}$ & $\sigma^{2}+2 r \sigma_{p a}^{2}+2 r a \sigma_{p g}^{2}$ & $/ Q M_{p g a}$ \\
Progênies x Genitores/E & $\mathrm{s}(\mathrm{p}-1)$ & $Q M_{p g}$ & $\sigma^{2}+r \sigma_{p g a}^{2}+r a \sigma_{p g}^{2}$ & $Q M_{p a} / Q M_{r}$ \\
Progênies x A/E & $(\mathrm{a}-1) \mathrm{s}(\mathrm{p}-1)$ & $Q M_{p a}$ & $\sigma^{2}+2 r \sigma_{p a}^{2}$ & $Q M_{p g a} / Q M_{r}$ \\
Progênies x Genitores x A/E & $(\mathrm{a}-1) \mathrm{s}(\mathrm{p}-1)$ & $Q M_{p g a}$ & $\sigma^{2}+r \sigma_{p g a}^{2}$ &
\end{tabular}

a, s, r e p são o número de ambientes, experimentos, repetições, e pares de progênies retrocruzadas para cada linhagem genitora, respectivamente. $Q M$ refere-se aos quadrados médios das fontes de variação de progênies $\left(Q M_{p}\right)$, interação progênies por ambientes $\left(Q M_{p g}\right)$, progênies por genitores e ambientes $\left(Q M_{p g a}\right)$ e do resíduo $\left(Q M_{r}\right)$.

\subsubsection{Parâmetros genéticos}

A partir das esperanças matemáticas dos quadrados médios da análise conjunta agrupada (Tabela 3). Os componentes de variância foram estimados pelo método dos momentos, como proposto por Comstock \& Robinson (1952):

Variância de progênies $\left(\sigma_{p}^{2}\right)$ :

$$
\hat{\boldsymbol{\sigma}}_{p}^{2}=\frac{Q M_{p}-Q M_{p a}}{2 r a} ;
$$

Variância da interação entre progênies e ambientes $\left(\sigma_{p a}^{2}\right)$ : 


$$
\hat{\sigma}_{p a}^{2}=\frac{Q M_{p a}-Q M_{r}}{2 r}
$$

Variância da interação entre progênies e linhagens genitoras $\left(\boldsymbol{\sigma}_{p g}^{2}\right)$ :

$$
\hat{\sigma}_{p g}^{2}=\frac{Q M_{p g}-Q M_{p g a}}{r a} ;
$$

Variância da interação entre progênies, linhagens genitoras e ambientes $\left(\sigma_{p g a}^{2}\right)$ :

$$
\hat{\sigma}_{p g a}^{2}=\frac{Q M_{p g}-Q M_{r}}{r}
$$

Variância do erro $\left(\sigma^{2}\right)$ :

$$
\hat{\boldsymbol{\sigma}}^{2}=Q M_{r} .
$$

Estimourse também o coeficiente de herdabilidade entre médias de progênies de meios-irmãos $\left(h_{\bar{x}}^{2}\right)$, de acordo com Wolf et al. (2000):

$$
\hat{h}_{x}^{2}=\frac{\hat{\boldsymbol{\sigma}}_{p}^{2}}{\hat{\boldsymbol{\sigma}}_{\bar{F}}^{2}},
$$

em que $\hat{\sigma}_{\bar{F}}^{2}$ é a estimativa da variância fenotípica fornecida por:

$$
\hat{\sigma}_{\bar{F}}^{2}=\frac{Q M_{p}}{2 r a} .
$$

Os componentes de variância genética e suas interações com ambientes foram estimadas por (Comstock \& Robinson, 1952):

$$
\begin{gathered}
\hat{\sigma}_{A}^{2}=4 \hat{\sigma}_{p}^{2} ; \hat{\sigma}_{A E}^{2}=4 \hat{\sigma}_{p a}^{2} \\
\hat{\sigma}_{D}^{2}=\hat{\sigma}_{p g}^{2} ; \hat{\sigma}_{D}^{2}=\hat{\sigma}_{p g a}^{2} \\
\hat{\sigma}_{G}^{2}=\hat{\sigma}_{A}^{2}+\hat{\sigma}_{D}^{2} ; \hat{\sigma}_{G E}^{2}=\hat{\sigma}_{A E}^{2}+\hat{\sigma}_{D E}^{2},
\end{gathered}
$$

e o grau médio de dominância $(\bar{d})$ foi estimado pela expressão:

$$
\hat{\bar{d}}=\sqrt{\frac{2 \hat{\sigma}_{D}^{2}}{\hat{\sigma}_{A}^{2}}} .
$$

em que: 
$\sigma_{A}^{2}$ : é a variância genética devida aos efeitos aditivos;

$\sigma_{A E}^{2}$ : é a variância da interação dos efeitos aditivos com ambientes;

$\sigma_{D}^{2}$ : é a variância genética associada aos efeitos de dominânc ia;

$\sigma_{D E}^{2}$ : é a variância da interação entre efeitos de dominância e ambientes;

$\sigma_{G}^{2}$ : é a variância genética;

$\sigma_{G E}^{2}$ : é a variância da interação entre efeitos genéticos e ambientes.

Os intervalos de confiança (IC) com 0,95 de probabilidade dos componentes de variância foram construídos segundo Barbin (1993):

$$
I C\left(\hat{\sigma}^{2}\right)_{0,95}=\left[\frac{n t \hat{\sigma}^{2}}{\chi_{n t: 0,975}^{2}} \leq \sigma^{2} \leq \frac{n t \hat{\sigma}^{2}}{\chi_{n t: 0,025}^{2}}\right],
$$

sendo: $n t$ o número de graus de liberdade associado à estimativa do componente de variância $\left(\hat{\sigma}^{2}\right) . \quad \chi_{n t: 0975}^{2}$ e $\chi_{n: 0,025}^{2}$ referem-se ao valor tabelado de $\chi^{2}$ com $n t$ graus de liberdade com 0,975 e 0,025 de probabilidade, respectivamente. Adotou-se a expressão de Satterwaite (1946) para estimar o número de graus de liberdade associados aos componentes de variância.

A precisão das estimativas de herdabilidade entre médias de progênies de meios-irmãos foi obtida utilizando o intervalo de confiança a 0,95 de probabilidade, como proposto por Knapp et al. (1985):

$$
I C\left(\hat{h}_{\bar{x}}^{2}\right)_{0,95}=\left\{1-\frac{1}{\left(\frac{Q M_{p}}{Q M_{p a}}\right) F_{0,975: G L p: G L p a}} \leq h_{\bar{x}}^{2} \leq 1-\frac{1}{\left(\frac{Q M_{p}}{Q M_{p a}}\right) F_{0,025: G L p: G L p a}}\right\} ;
$$

em que: $F_{0,975: G L p: G L p a}$ e $F_{0,025: G L p: G L p a}$ referem-se ao valor tabelado de $F$ a 0,975 e 0,025 de probabilidade, respectivamente, com os graus de liberdade de progênies (GLp) e graus de liberdade da interação de progênies por ambientes ( GLpa). 
A avaliação da precisão da estimativa do grau médio de dominância $(\hat{\bar{d}})$ foi obtida com a construção do intervalo de confiança aproximado para $\hat{\bar{d}}$ de acordo com Burdick \& Graybill (1992):

$$
I C(\hat{\bar{d}})_{0,95}=\left[\sqrt{\frac{M_{1}}{M_{2} F_{0,975: n 1: n 2}}} \leq \bar{d} \leq \sqrt{\frac{M_{1}}{M_{2} F_{0,025 n 1: n 2}}}\right],
$$

em que:

$$
\begin{aligned}
& M_{1}=Q M_{p g}-Q M_{p g a}, \\
& M_{2}=Q M_{p}-Q M_{p a},
\end{aligned}
$$

$F_{0,975: n 1: n 2}$ e $F_{0,025 n: n 2}$ referem-se ao valor tabelado de $F$ a 0,975 e 0,0250 de probabilidade, respectivamente, com $n 1$ e $n 2$ graus de liberdade associados aos componentes $M_{1}$ e $M_{2}$, respectivamente, estimados pela expressão de Satterwaite (1946).

\subsubsection{Análises de covariância e correlações entre caracteres}

Foram estimados os coeficientes de correlação genética aditiva, genética total e fenotípica entre os caracteres analisados com o objetivo de verificar as associações entre os caracteres analisados. Para isso, inicialmente foi obtido o quadro de produtos médios entre dois caracteres $x$ e $y$, da seguinte forma; a partir das análises de variância conjunta agrupada para os caracteres $x$ e $y$ e da variável fornecida pela soma entre $x$ e $y$, obtiveram-se os produtos médios $(P M)$, utilizando a seguinte propriedade (Steel \& Torrie, 1980):

$$
P M_{x y}=\frac{1}{2}\left(Q M_{x+y}-Q M_{x}-Q M_{y}\right)
$$

em que: $Q M_{x+y}, Q M_{x}$ e $Q M_{y}$ referem-se aos quadrados médios de uma determinada fonte de variação, das análises considerando a soma entre os caracteres $x$ e $y$, do caráter $x$ e do $y$, respectivamente. 
As esperanças matemáticas dos produtos médios são semelhantes as dos quadrados médios apresentadas na Tabela 3, com a diferença de que ao invés de componentes de variância são componentes de covariâncias. A partir destas esperanças foi possível estimar os seguintes parâmetros genéticos:

Covariância aditiva $\left(\operatorname{Cov}_{A x y}\right)$ :

$$
C \hat{o} v_{A x y}=4 C \hat{o} v_{P x y}=\frac{4\left(P M_{P x y}-P M_{P A x y}\right)}{2 r a} ;
$$

Covariância de dominância $\left(\operatorname{Cov}_{D x y}\right)$ :

$$
C \hat{o} v_{D x y}=C \hat{o} v_{P G x y}=\frac{P M_{P G x y}-P M_{P G A x y}}{r a} ;
$$

Covariância genética $\left(\operatorname{Cov}_{G x y}\right)$ :

$$
C \hat{o} v_{G x y}=C \hat{o} v_{A x y}+C \hat{o} v_{D x y}
$$

Covariância fenotípica $\left(\operatorname{Cov}_{\bar{F} x y}\right)$ :

$$
C \hat{o} v_{\bar{F} x y}=\frac{P M_{P x y}}{2 r a} ;
$$

em que: $P M$ refere-se a produtos médios e os sub-índices $p, p a, p g$ e $p g a$ referem-se às fontes de variação de progênies, progênies por ambientes, progênies por linhagens genitoras e progênies por linhagens genitoras por ambientes, respectivamente; $a$ é o número de ambientes, e $r$ o número de repetições.

A partir destes parâmetros genéticos foram estimadas as correlações aditiva $\left(r_{a x y}\right)$, genética $\left(r_{g x y}\right)$ e fenotípica $\left(r_{F x y}\right)$ entre os caracteres $x$ e $y$, respectivamente:

$$
\hat{r}_{a x y}=\frac{C \hat{O} V_{A x y}}{\sqrt{\hat{\boldsymbol{\sigma}}_{A x}^{2} \hat{\boldsymbol{\sigma}}_{A y}^{2}}}
$$




$$
\begin{aligned}
& \hat{r}_{g x y}=\frac{C \hat{O} V_{G x y}}{\sqrt{\hat{\sigma}_{G x}^{2} \hat{\sigma}_{G y}^{2}}} \mathrm{e} \\
& \hat{r}_{\bar{F} x y}=\frac{C \hat{O} V_{\bar{F} x y}}{\sqrt{\hat{\sigma}_{\bar{F} x}^{2} \hat{\sigma}_{\bar{F} y}^{2}}}
\end{aligned}
$$

em que: $\hat{\boldsymbol{\sigma}}_{A x}^{2}$ e $\hat{\boldsymbol{\sigma}}_{A y}^{2}$ são as estimativas das variâncias aditivas dos caracteres $x \mathrm{e} y, \hat{\boldsymbol{\sigma}}_{G x}^{2} \mathrm{e}$ $\hat{\boldsymbol{\sigma}}_{G y}^{2}$ são as estimativas das variâncias genéticas dos caracteres $x$ e $y$; e $\hat{\sigma}_{\bar{F} x}^{2}$ e $\hat{\sigma}_{\overline{F y}}^{2}$ são as estimativas das variâncias fenotípicas dos caracteres $x$ e $y$, respectivamente.

A correlação fenotípica foi testada utilizando procedimento apresentado por Stell \& Torrie (1980). Foi adotado o teste de $t$ de Student para testar se a correlação é igual a zero $(\rho=0)$. O valor de $t$ foi calculado pela seguinte expressão:

$$
t=\frac{\hat{r}_{\bar{F} x y}}{\sqrt{\left(1-\hat{r}_{\bar{F} x y}^{2}\right) /(n-2)}} ;
$$

em que, $n$ é o número de pares de progênies avaliadas $(n=250)$ e $\hat{r}_{\bar{F} x y}$ é a estimativa da correlação fenotípica.

\subsubsection{Análise genética utilizando o delineamento III com marcadores moleculares}

Esta metodologia baseia-se em contrastes ortogonais entre as médias fenotípicas das progênies genotipadas. Estes contrastes permitem estimar os efeitos genéticos dos QTLs associados aos marcadores. A partir deles pode-se estimar os efeitos aditivos, dominantes e epistáticos dos QTLs. Além disso, desde que as progênies sejam avaliadas em mais de um ambiente, é possível estimar o efeito da interação entre efeitos genéticos e ambientes. Na realização dessas análises foram adotadas as médias ajustadas das progênies retrocruzadas para ambos genitores. A seguir é descrito como foram realizadas as análises do delineamento III com marcadores moleculares. 


\subsubsection{Contrastes}

Os contrastes foram obtidos em função das estimativas das médias ajustadas para látice da análise conjunta agrupada. Os contrastes são:

$$
\begin{gathered}
C_{1}=\bar{Y}_{M M(L A)}-\bar{Y}_{m m(L A)}+\bar{Y}_{M M(L B)}-\bar{Y}_{m m(L B)}, \\
C_{2}=\bar{Y}_{M M(L A)}+\bar{Y}_{m m(L A)}-2 \bar{Y}_{M m(L A)}+\bar{Y}_{M M(L B)}+\bar{Y}_{m m(L B)}-2 \bar{Y}_{M m(L B)}, \\
C_{3}=\bar{Y}_{M M(L A)}-\bar{Y}_{m m(L A)}-\bar{Y}_{M M(L B)}+\bar{Y}_{m m(L B)}, \\
C_{4}=\bar{Y}_{M M(L A)}+\bar{Y}_{m m(L A)}-2 \bar{Y}_{M m(L A)}-\bar{Y}_{M M(L B)}-\bar{Y}_{m m(L B)}+2 \bar{Y}_{M m(L B)},
\end{gathered}
$$

em que: $\bar{Y}_{M M}, \bar{Y}_{M m}$ e $\bar{Y}_{m m}$ referem-se às médias fenotípicas ajustadas de um caráter quantitativo das progênies agrupadas de acordo com os genótipos dos marcadores $M M$, $M m$, e $m m$, respectivamente; $L_{A}$ e $L_{B}$ referem-se às linhagens genitoras L-14-04B e L-08$05 \mathrm{~F}$, respectivamente.

Os contrastes são transformados em coeficientes de regressão linear parciais de uma análise de regressão múltipla. O coeficiente de regressão linear é estimado por $\beta_{r}=C_{r} / \sum_{t=1}^{4,6} X_{t}^{2}$, em que $C_{r}$ é o contraste em questão $(r=1, \ldots, 4)$ e $X_{t}^{2}$ refere-se aos coeficientes que multiplicam os componentes dos respectivos contrastes. Para cada contraste têm-se os seguintes coeficientes de regressão:

$$
\beta_{1}=C_{1} / 4, \quad \beta_{2}=C_{2} / 12, \quad \beta_{3}=C_{3} / 4 \quad \text { e } \quad \beta_{4}=C_{4} / 12 \text {. }
$$

\subsubsection{Análise de variância para marcador molecular}

A associação entre um QTL e o marcador molecular é realizada a partir de uma análise de variância simples. As fontes de variação são devido aos efeitos dos contrastes e as suas interações com ambientes (Tabela 4). 
A soma de quadrados para cada contraste é obtida pela seguinte expressão:

$$
S Q C_{s a r}=\left(\sum_{a=1}^{n} C_{s a r}\right)^{2} /\left[n\left(\sum_{t=1}^{4,6} X_{t}^{2}\right)\right],
$$

em que $S Q C_{\text {sar }}$ é a soma de quadrados para o contraste $r(r=1, \ldots, 4)$ para o $s$-ésimo marcador $(s=1, \ldots, 140)$ no $a$-ésimo ambiente $(a=1, \ldots, 6)$ e $n$ é número total de ambientes avaliados.

Considerando a avaliação das progênies em seis ambientes, têm-se as seguintes expressões para soma de quadrados de cada contraste:

$$
\begin{aligned}
& S Q C_{s a 1}=\left(\sum_{a=1}^{6} C_{s a 1}\right)^{2} / 24 ; \\
& S Q C_{s a 2}=\left(\sum_{a=1}^{6} C_{s a 2}\right)^{2} / 72 ; \\
& S Q C_{s a 3}=\left(\sum_{a=1}^{6} C_{s a 3}\right)^{2} / 24 ; \mathrm{e} \\
& S Q C_{s a 4}=\left(\sum_{a=1}^{6} C_{s a 4}\right)^{2} / 72 .
\end{aligned}
$$

Os quadrados médios dos contrastes têm o mesmo valor que as somas de quadrados, já que estes possuem apenas um grau de liberdade. A soma de quadrados para a interação de contrastes com ambientes $\left(S Q C_{s a r+E}\right)$ foi obtida da seguinte maneira:

$$
S Q C_{s a r+E}=\left[\sum_{a=1}^{n} C_{s a r}^{2} / \sum_{t}^{4,6} X_{t}^{2}\right]-S Q C_{s a r}
$$

A esta soma de quadrados está associada $(a-1)$ graus de liberdade. O quadrado médio da interação de contrastes com ambientes $\left(Q M C_{i j r+E}\right)$ fica:

$$
Q M C_{s a r+E}=S Q C_{s a r+E} /(a-1) .
$$


Para obtenção da soma de quadrados dos resíduos, inicialmente obtém-se uma soma de quadrados entre as médias ajustadas das progênies que apresentam um determinado genótipo, considerando cada retrocruzamento e ambiente. Posteriormente somam-se todas estas somas de quadrados. A expressão para a soma de quadrados de resíduo, considerando somente as progênies com genótipo $M M$ retrocruzadas para o genitor $j$ avaliado no ambiente $a$ é:

$$
S Q R_{(M M) j a}=\sum_{p=1}^{H} \bar{Y}_{(M M) p j}^{2}-\left[\left(\sum_{p=1}^{H} \bar{Y}_{(M M) p j}\right)^{2} / H\right],
$$

em que $\bar{Y}_{(M M) p j}$ refere-se à média fenotípica ajustada da progênie $p$ com genótipo $M M$, retrocruzada com o genitor $j$, e $H$ refere-se ao número de progênies com genótipo $M M$.

Considerando todos os genótipos dos marcadores, ambientes e os dois retrocruzamentos, tem-se que a soma de quadrados dos resíduos, para o s-ésimo marcador é:

$$
S Q R_{s}=\sum_{s=1}^{3} \sum_{j=1}^{2} \sum_{a=1}^{6} S Q R_{g j a}
$$

e considerando os seis ambientes e as 250 progênies retrocruzadas, tem-se que o quadrado médio do resíduo para o $s$-ésimo marcador $\left(Q M R_{s}\right)$ é:

$$
Q M R_{s}=S Q R_{s} / G L_{r e s} .
$$


Tabela 4. Resumo da análise de variância com as esperanças matemáticas dos quadrados médios e teste $F$ para o marcador $s$, considerando o delineamento III associado a marcadores moleculares (Cockerham \& Zeng, 1996).

\begin{tabular}{lcccc}
\hline Fonte de Variação & $\mathrm{GL}^{1}$ & $\mathrm{QM}$ & $\mathrm{E}(\mathrm{QM})^{2}$ & Teste F \\
\hline $\mathrm{C}_{1}$ & 1 & $Q M_{c 1}$ & $\sigma_{s}^{2} / S_{s 1}+4 \sigma_{\beta s 1 E}^{2}+4 a \beta_{s 1}^{2}$ & $Q M_{c 1} / Q M_{c l E}$ \\
$\mathrm{C}_{2}$ & 1 & $Q M_{c 2}$ & $\sigma_{s}^{2} / S_{s 2}+12 \sigma_{\beta s 2 E}^{2}+12 a \beta_{s 2}^{2}$ & $Q M_{c 2} / Q M_{c 2 E}$ \\
$\mathrm{C}_{3}$ & 1 & $Q M_{c 3}$ & $\sigma_{s}^{2} / S_{s 3}+4 \sigma_{\beta s 3 E}^{2}+4 a \beta_{s 3}^{2}$ & $Q M_{c 3} / Q M_{c 3 E}$ \\
$\mathrm{C}_{4}$ & 1 & $Q M_{c 4}$ & $\sigma_{s}^{2} / S_{s 4}+12 \sigma_{s i 4 E}^{2}+12 a \beta_{s 4}^{2}$ & $Q M_{c 4} / Q M_{c 4 E}$ \\
$\mathrm{C}_{1}+\mathrm{E}$ & $\mathrm{a}-1$ & $Q M_{c 1 E}$ & $\sigma_{s}^{2} / S_{s 1}+4 \sigma_{\beta s 1 E}^{2}$ & $\left(Q M_{c l E} S_{s 1}\right) / Q M_{r}$ \\
$\mathrm{C}_{2}+\mathrm{E}$ & $\mathrm{a}-1$ & $Q M_{c 2 E}$ & $\sigma_{s}^{2} / S_{s 2}+12 \sigma_{\beta s 2 E}^{2}$ & $\left(Q M_{c 2 E} S_{s 2}\right) / Q M_{r}$ \\
$\mathrm{C}_{3}+\mathrm{E}$ & $\mathrm{a}-1$ & $Q M_{c 3 E}$ & $\sigma_{s}^{2} / S_{s 3}+4 \sigma_{\beta s 3 E}^{2}$ & $\left(Q M_{c 3 E} S_{s 3}\right) / Q M_{r}$ \\
$\mathrm{C}_{4}+\mathrm{E}$ & $\mathrm{a}-1$ & $Q M_{c 4 E}$ & $\sigma_{s}^{2} / S_{s 4}+12 \sigma_{\beta s 4 E}^{2}$ & $\left(Q M_{c 4 E} S_{s 4}\right) / Q M_{r}$ \\
Erro & $2 \mathrm{a}\left(\mathrm{S}_{1}-3\right)$ & $Q M_{r}$ & $\sigma_{s}^{2}$ & \\
Total & $2 \mathrm{aS}-1$ & & & \\
\hline
\end{tabular}

Fonte: Cockerham \& Zeng (1996)

1 a: número de ambientes em que as progênies foram avaliadas, $\mathrm{S}$ : número de plantas genotipadas para o marcador $s ;{ }^{2} \cdot S_{s 1}=S_{s 3}=2 /\left(1 / S_{s M M}+1 / S_{s m m}\right)$ e $S_{s 2}=S_{s 4}=6 /\left(1 / S_{s M M}+4 / S_{s M m}+1 / S_{s m m}\right)$ em que $S_{s M M}, S_{s M m}$ e $S_{s m m}$ é número de plantas genotipadas com os genótipos $M M, M m$ e $m m$. 


\section{RESULTADOS E DISCUSSÃO}

$\mathrm{Na}$ apresentação dos resultados e discussão será abordada inicialmente a análise clássica do delineamento III (Comstock \& Robinson, 1948, 1952), seguida da metodologia proposta por Cockerham \& Zeng (1996), associando o delineamento III com marcadores moleculares.

\subsection{Análise clássica do delineamento III}

\subsubsection{Médias e análises de variâncias}

As análises agrupadas para cada ambiente mostraram que não houve problemas de condução experimental e/ou adversidade climática que afetassem o desenvolvimento da cultura. Considerando, por exemplo, a produção de grãos (PG), verificou-se que o coeficiente de variação (CV) não foi elevado, e apresentou um intervalo de variação, de $12,37 \%$ a $17,01 \%$. As médias para PG das progênies retrocruzadas foram elevadas, variando de $90,19 \mathrm{~g} \mathrm{planta}^{-1}$ (5,64 ton/ha - Amb. 6) a 151,96 g planta ${ }^{-1}$ (9,50 ton/ha Amb. 3). Outro fato que corrobora a boa precisão experimental foi a detecção de significância $(P \leq 0,05)$ das fontes de variação de progênies e interação entre progênies e linhagens genitoras para todos os caracteres na maioria dos ambientes (Tabela 15).

De acordo com as análises de variância conjuntas agrupadas, houve diferença significativa entre as progênies. As interações progênies por genitores e progênies por ambientes foram significativas para todos os caracteres, enquanto a interação progênies por genitores por ambientes, só não foi significativa para os caracteres peso de 500 grãos (P500) e número de ramificações do pendão (RP). Estes fatos indicam que as progênies 
avaliadas apresentaram variabilidade genética para os caracteres analisados, e que as linhagens genitoras contribuíram de maneira diferenciada para as progênies. A significância da interação de progênies com ambientes, indica que as progênies se comportaram de maneira diferenciada nos ambientes avaliados, e a interação de progênies por linhagens genitoras por ambientes, verificada para os caracteres PG, prolificidade (PROL), diâmetro da espiga (DE), comprimento da espiga (CE), e número de fileiras (NFI), número de grãos por fileira (NGF) evidencia que as progênies retrocruzadas para cada linhagem genitora também foram afetadas pelas condições ambientais (Tabela 5).

Os coeficientes de variação experimentais obtidos nas análises conjuntas agrupadas foram de 14,24\% para PG, 12,97\% para PROL, 3,31\% para DE, 4,30\% para CE, 5,63\% para NGF, 5,18\% para NFI, 6,18\% para P500 e 10,18\% para RP (Tabela 5). Pode-se considerar que a precisão experimental obtida nos experimentos foi boa, já que a maioria dos caracteres avaliados apresentou CVs menores que $10 \%$, e que foram obtidos de progênies endogâmicas retrocruzadas. Coeficientes de variação com magnitudes semelhantes às reportadas neste trabalho são comuns na literatura para estes caracteres.

Para PG, as progênies retrocruzadas apresentaram na análise conjunta média de 116,35 $\mathrm{g} \mathrm{planta}^{-1}$ (7,27 ton/ha), com intervalo de variação de 70,41 g planta ${ }^{-1}$ (4,40 ton/ha) a 155,57 $\mathrm{g}_{\text {planta }}{ }^{-1}$ (9,72 ton/ha), evidenciando a variabilidade genética existente entre as progênies. Pode-se notar também o efeito das linhagens genitoras, haja vista que para todos os caracteres, exceto NGF, a média das progênies retrocruzadas para a linhagem L-14-04B foi significativamente diferente da média das progênies retrocruzadas para a linhagem L-08-05F (Tabela 5).

Considerando as análises conjuntas agrupadas, o caráter PROL apresentou média de progênies de 1,09 esp. planta $^{-1}$, com um intervalo de variação de 0,71 esp. planta $^{-1}$ a 1,38 esp. planta $^{-1}$. A média do caráter DE foi de $4,19 \mathrm{~cm} \mathrm{esp.}^{-1}$, com intervalo de variação de $3,74 \mathrm{~cm} \mathrm{esp.}^{-1}$ a 4,71 $\mathrm{cm}$ esp. ${ }^{-1}$. Para o caráter CE, a média foi de $16,09 \mathrm{~cm}$ esp. $^{-1}$ e o intervalo de variação foi de $14,40 \mathrm{~cm} \mathrm{esp.}^{-1}$ a $18,23 \mathrm{~cm} \mathrm{esp.}^{-1}$. A média do caráter NGF foi de 34,90 grãos fill. ${ }^{-1}$, com intervalo de variação de 30,35 grãos fil. $^{-1}$ a 
38,99 grãos fil. ${ }^{-1}$. A média das progênies para NFI foi de 11,90 fil. esp. ${ }^{-1}$ e seu intervalo de variação foi de 8,83 fil. esp. $^{-1}$ a 14,78 fil. esp. ${ }^{-1}$. A média das progênies para P500 foi de $155,93 \mathrm{~g}$, com intervalo de variação de $120,89 \mathrm{~g}$ a $184,88 \mathrm{~g}$. As progênies retrocruzadas para a linhagem L-14-04B foram mais produtivas (126,03 $\left.\mathrm{g} \mathrm{planta}^{-1}\right)$, prolíficas (1,22 esp. planta $\left.^{-1}\right)$ e apresentaram maior P500 (167,81 g), enquanto as progênies retrocruzadas para L-08-05F apresentaram maior $\mathrm{DE}\left(4,33 \mathrm{~cm} \mathrm{esp.}^{-1}\right), \mathrm{CE}$ $\left(16,21 \mathrm{~cm} \mathrm{esp.}^{-1}\right)$ e NFI $\left(13,37\right.$ fil. esp. $\left.^{-1}\right)$. Para o NGF não foi verificada diferença significativa entre as médias das progênies retrocruzadas com as linhagens genitoras (Tabela 5).

O caráter número de ramificações do pendão (RP) apresentou média de 16,50 ram. pendão ${ }^{-1}$, com intervalo de variação de 11,78 ram. pendão ${ }^{-1}$ a 21,94 ram. pendão ${ }^{-1}$. O número de ramificações do pendão das progênies retrocruzadas com L-14-04 (15,26 ram. pendão ${ }^{-1}$ ) foi significativamente menor que a das progênies retrocruzadas com L-0805F (17,75 ram. pendão $\left.{ }^{-1}\right)$ (Tabela 5).

Os resultados obtidos das análises de variâncias conjuntas agrupadas, bem como a amplitude de variação, corroboram a existência de variabilidade genética entre progênies para os caracteres analisados. As progênies retrocruzadas com a linhagem L14-04B foram significativamente superiores em PG, PROL e P500 que aquelas retrocruzadas com L-08-05F. Este fato indica que a linhagem L-14-04B apresenta maior concentração de alelos favoráveis para estes caracteres que a linhagem L-08-05F. Gardner \& Lonquist (1959) avaliaram o cruzamento entre as linhagens L-187-2 e M-14 utilizando o delineamento III. Para os caracteres analisados, os autores observaram que as progênies retrocruzadas para a linhagem L-184-2 foram mais produtivas, e apresentaram maior PROL e CE. Moll et. al (1964), avaliando dois cruzamentos (NC7 x CI21 e NC33 x K64), observaram que as progênies retrocruzadas para as linhagens mais produtivas (NC7 e NC33) apresentaram maior PROL, mas não diferiram quanto ao $\mathrm{CE}$ e DE, estes autores verificaram também que a média das progênies retrocruzadas foram significativamente diferentes. Han \& Hallauer (1989) avaliaram as gerações $F_{2}$ e " $F_{5}$ " de dois cruzamentos. Em um cruzamento (B73 x Mo17), as progênies retrocruzadas para a 
linhagem mais produtiva (B73) apresentaram maior DE e NGF e menor CE, que as progênies retrocruzadas para Mo17. No outro cruzamento (B73 x B84), o resultado obtido na geração $F_{2}$ não se repetiu em " $F_{5}$ " para o caráter $P G$, porém, as progênies retrocruzadas para B73 apresentaram maior DE e NFI e menor CE.

Comparando os resultados apresentados na literatura com os obtidos neste trabalho, verifica-se que as progênies mais produtivas tendem a ser mais prolífica (Gardner \& Lonquist, 1959; Moll et al., 1964), fato este já descrito por outros autores (Geraldi et al, 1985; Souza Júnior et al, 1985). Para os demais caracteres, não foi verificada uma concordância de resultados, o que pode ser devido à origem do germoplasma utilizado.

\subsubsection{Componentes de variância}

A avaliação das progênies em seis ambientes com duas repetições, associada às boas condições para o desenvolvimento da cultura, possibilitaram a obtenção de estimativas dos parâmetros genéticos com boa precisão. Isto se refletiu nos pequenos intervalos de confiança obtidos para as estimativas dos componentes de variância, herdabilidade, grau médio de dominância e na significância da grande maioria dos componentes de variância, exceção verificada para os componentes da interação de dominância por ambientes para os caracteres P500 e RP (Tabela 6).

A seguir serão apresentados e discutidos os parâmetros genéticos dos caracteres analisados.

\subsubsection{Produção de grãos}

A estimativa da variância genética aditiva $\left(\hat{\sigma}_{A}^{2}\right)$ do caráter PG foi de 140,53 (g $\left.\operatorname{planta}^{-1}\right)^{2}$ e da variância de dominância $\left(\hat{\sigma}_{D}^{2}\right)$ foi de $154,66\left(\mathrm{~g} \operatorname{planta}^{-1}\right)^{2}$. Apesar da $\hat{\sigma}_{D}^{2}$ ter sido superior a $\hat{\sigma}_{A}^{2}$, os intervalos de confiança destas estimativas se sobrepuseram, 
indicando que estas não diferiram significativamente entre si (Tabela 6). Estimativas semelhantes entre $\hat{\sigma}_{A}^{2}$ e $\hat{\sigma}_{D}^{2}$, e até de $\hat{\sigma}_{D}^{2}$ superior a $\hat{\sigma}_{A}^{2}$, são comuns na literatura (Robinson et al., 1949; Gardner et al., 1953; Gardner \& Lonquist, 1959; Moll et al., 1964; Ramalho, 1977; Obilana et al., 1979; Hallauer \& Miranda Filho, 1988; Han \& Hallauer, 1989; Holthaus \& Lamkey, 1995; Cockerham \& Zeng, 1996; Wolf et al., 2000). Deve-se salientar que a grande maioria das estimativas de $\hat{\sigma}_{A}^{2}$ e de $\hat{\sigma}_{D}^{2}$ apresentadas na literatura são referentes a germoplasma de origem temperada. Apesar disso, as estimativas de $\hat{\sigma}_{A}^{2}$ e $\hat{\sigma}_{D}^{2}$ obtidas neste trabalho foram de magnitudes semelhante às apresentadas na literatura. Estes resultados corroboram que os efeitos de dominância são importantes no controle genético da produção de grãos também em germoplasma de origem tropical.

A estimativa da interação da variância aditiva com ambientes $\left(\hat{\sigma}_{A E}^{2}\right), 81,56(\mathrm{~g}$ planta $\left.^{-1}\right)^{2}$, foi significativamente superior à estimativa da interação de dominância por ambientes $\left(\hat{\sigma}_{D E}^{2}\right), 32,23\left(\mathrm{~g} \text { planta }^{-1}\right)^{2}$ (Tabela 6). Estes resultados indicam que os efeitos aditivos interagiram mais com os ambientes que os efeitos de dominância. Trabalhos indicando maior interação de efeitos aditivos com ambientes foram relatados por Obilana et al. (1979), Hallauer \& Miranda Filho (1988), Han \& Hallauer (1989) e Wolf et al. (2000). A estimativa do coeficiente de herdabilidade entre médias de progênies de meiosirmãos $\left(\hat{h}_{\bar{X}}^{2}\right)$ foi de 0,70 , indicando que grande parte variância fenotípica foi devida à variância genética, e que a seleção para a PG deve ser eficiente. A elevada estimativa de $\hat{h}_{\bar{X}}^{2}$, deve-se provavelmente ao número de ambientes de avaliação. Wolf et al. (2000) obtiveram estimativa de $\hat{h}_{\bar{X}}^{2}$ de 0,44. Em um programa de melhoramento de plantas, estimativas de componentes de variância genética e do coeficiente de herdabilidade são importantes para escolha adequada da estratégia de melhoramento, além de possibilitar a obtenção de estimativas de ganhos com a seleção. Estas informações auxiliam na identificação de genótipos superiores, com base em valores fenotípicos. 
A estimativa do grau médio de dominância $(\hat{\bar{d}})$ da PG foi de 1,48 , significativamente superior a um, indicando a presença de efeitos de sobredominância no controle genético deste caráter. Diversos autores relataram estimativas de $\hat{\bar{d}}$ superiores a 1,00 para PG em milho (Robinson et al., 1949; Gardner et al., 1953; Gardner \& Lonquist, 1959; Moll et al., 1964; Han \& Hallauer, 1989; Cockerham \& Zeng, 1996; Wolf et al., 2000). Porém, grande parte desses trabalhos utilizou populações $F_{2}$ para estimar os componentes de variância. Isto pode levar à obtenção de estimativas viesadas de componentes de variância aditiva e de dominância, pois, devido ao desequilíbrio de ligação, surge uma covariância entre os efeitos dos locos que controlam o caráter. Esses fatos podem levar à ocorrência de estimativas de $\hat{\bar{d}}$ superiores a um, causando o efeito de pseudo-sobredominância (Comstock \& Robinson, 1952).

Gardner \& Lonquist (1959) obtiveram estimativas de $\hat{\bar{d}}$ nas gerações $F_{2}$ e em gerações avançadas de recombinação ("F8") para sete caracteres em milho, a partir de duas amostras do cruzamento entre as linhagens M14 e M187-2. Os autores verificaram que houve uma redução nas estimativas de $\hat{\bar{d}}$ com o decorrer das gerações de recombinação para os caracteres analisados. Para PG, a estimativa do $\hat{\bar{d}}$ na geração $\mathrm{F}_{2}$, foi de 0,56 na amostra 1 , e 1,59 na amostra 2; na geração " $F_{8}$ " foi de 0,60 para amostra 1 e 0,93 para amostra 2. Em trabalho semelhante, realizado por Moll et al. (1964), estimaram o $\hat{\bar{d}}$ nas gerações $F_{2}$, " $F_{8}$ ", " $F_{12}$ " e "F $F_{13}$ ", e também verificaram uma tendência de redução na estimativa do grau médio de dominância com o decorrer do número de gerações de recombinação para diversos caracteres analisados. Estes autores obtiveram estimativas de $\hat{\bar{d}}$ para o caráter PG de 1,49 na geração $F_{2}, 1,24$ na geração "F8", e de 1,09 na geração " $F_{13}$ ". Outros trabalhos também obtiveram resultados similares (MorenoGonzález et al., 1975; Han \& Hallauer, 1989; Dudley, 1994). Estes resultados indicam que o desequilíbrio de ligação pode estar causando viéses nas estimativas da variância aditiva e de dominância e, conseqüentemente, na estimativa do grau médio de dominância. Considerando dois locos com dois alelos por loco, a expressão da "variância 
aditiva" é $\quad \sigma_{A}^{2 n}=\sigma_{A}^{2} \pm 2(1-2 r) a_{1} a_{2} \quad$ e a "variância de dominância" por $" \sigma_{D}^{2} "=\sigma_{D}^{2}+2(1-2 r)^{2} d_{1} d_{2}$. Quando a fase de ligação dos alelos que controlam o caráter estão em fase de associação, tanto as estimativas de variância aditiva quanto de dominância ficam superestimadas. Porém, quando os alelos se encontram em repulsão, a variância aditiva fica subestimada e a variância de dominância superestimada. Considerando que o número de genes envolvidos na herança de caracteres quantitativos, espera-se que ocorram genes ligados tanto em fase de repulsão quanto em associação, este fato faz com que a estimativa da variância aditiva deve ser subestimada e a variância de dominância superestimada. Estes viéses nas estimativas dos componentes da variância genética geram por conseguinte, estimativas viesadas de $\hat{\bar{d}}$, já que $\hat{\bar{d}}=\sqrt{2 \hat{\sigma}_{D}^{2} / \hat{\sigma}_{A}^{2}}$. Devido a isso, espera-se que estimativas de $\hat{\bar{d}}$ obtidas a partir de populações em desequilíbrio de ligação devem ser superiores as obtidas em populações após algumas gerações de recombinação. Apesar disso, não se pode descartar a hipótese de ocorrência da sobredominância.

\subsubsection{Componentes da produção}

A estimativa da $\hat{\sigma}_{A}^{2}$ para prolificidade foi de $71,49 \times 10^{-4}\left(\text { esp. } \text { planta }^{-1}\right)^{2}$ e da $\hat{\sigma}_{D}^{2}$ de $23,28 \times 10^{-4}$ (esp. planta $\left.^{-1}\right)^{2}$. Estas estimativas foram significativamente diferentes, já que não ocorreu uma sobreposição dos intervalos de confiança das mesmas. As estimativas dos componentes $\hat{\sigma}_{A E}^{2}$ e $\hat{\sigma}_{D E}^{2}$ foram menores que seus respectivos componentes de variância genética, $\hat{\sigma}_{A}^{2}$ e $\hat{\sigma}_{D}^{2}$, porém não apresentaram diferenças significativas entre si. A precisão dos componentes de variância genética que interagiram com ambientes $\left(\hat{\sigma}_{A E}^{2}\right.$ e $\left.\hat{\sigma}_{D E}^{2}\right)$ foi baixa, devido ao pequeno número de graus de liberdade associado a estes componentes (Tabela 6). As magnitudes dos componentes de variância obtidos neste trabalho para PROL foram semelhantes aos trabalhos relatados, indicando similaridade no controle genético da PROL tanto em germoplasma de origem tropical 
quanto de origem temperada (Robinson et al., 1949; Moll et al., 1964; Souza Júnior et al., 1985; Lemos e al., 1992; Holthaus \& Lamkey, 1995; Malvar et al., 1996; Wolf et at., 2000).

A estimativa do coeficiente de $\hat{h}_{\bar{X}}^{2}$ para PROL foi de 0,66. Esta estimativa pode ser considerada elevada, e indica que a variância genética aditiva explicou a maior parte da variância fenotípica (Tabela 6). Na literatura são apresentadas algumas estimativas de herdabilidade para médias de meios-irmãos para PROL. Souza Júnior et al. (1985) avaliando 100 progênies de meios-irmãos da população BR-105, obteve magnitude de $\hat{h}_{\bar{X}}^{2}$ de 0,36 . Wolf et al. (2000), utilizando o delineamento III, obteve estimativa de $\hat{h}_{\bar{X}}^{2}$ de 0,40. Em levantamento realizado por Hallauer \& Miranda Filho (1988), os autores apresentaram estimativas de herdabilidade entre médias de parcelas de 0,39. A magnitude obtida neste trabalho foi superior à relatada na literatura, isto, provavelmente, devido à maior variabilidade genética entre as progênies e ao elevado número de ambientes avaliados. O $\hat{\bar{d}}$ estimado para PROL foi de 0,81 . O intervalo de confiança do $\hat{\bar{d}}$ englobou o valor 1,00, indicando que no controle genético da PROL os efeitos de dominância foram tão importantes quanto os efeitos aditivos (Tabela 6). Na literatura ño há consenso sobre as estimativas de $\hat{\bar{d}}$ para PROL. As estimativas apresentadas na literatura variam de 0,30 a 0,87 (Robinson et al., 1949; Gardner et al., 1953; Gardner \& Lonquist, 1959; Moll et al., 1964; Cockerham \& Zeng, 1996; Wolf et al., 2000). Uma das causas dessa variação refere-se à fonte de germoplasma adotado no trabalho. Outro motivo, pode ser a geração utilizada para estimar os componentes de variância, já que em gerações em que há desequilíbrio de ligação, as estimativas de $\hat{\sigma}_{A}^{2}$ e $\hat{\sigma}_{D}^{2}$ podem estar viesadas. Apesar disso, estas estimativas sugerem que tanto os efeitos dominantes quanto aditivos foram importantes no controle genético da PROL.

Para CE, foram obtidas estimativas para $\hat{\sigma}_{A}^{2}$ de $38,91 \times 10^{-2}\left(\mathrm{~cm} \mathrm{esp.}^{-1}\right)^{2}$ e para $\hat{\sigma}_{D}^{2}$ de $14,04 \times 10^{-2}\left(\mathrm{~cm} \mathrm{esp.}^{-1}\right)^{2}$. Não foi verificado sobreposição dos intervalos de confiança, indicando que estas estimativas foram significativamente diferentes. Os 
componentes $\hat{\sigma}_{A E}^{2}$ e $\hat{\sigma}_{D E}^{2}$ não diferiram significativamente entre si, o que indica que tanto os efeitos aditivos quanto os de dominância interagiram com a mesma intensidade com os ambientes. Apesar de significativos, os componentes de variância genética que interagiram com ambientes $\left(\begin{array}{llll}\hat{\sigma}_{A E}^{2} & \mathrm{e} & \hat{\sigma}_{D E}^{2}\end{array}\right)$ foram inferiores aos seus respectivos componentes genéticos, $\hat{\sigma}_{A}^{2}$ e $\hat{\sigma}_{D}^{2}$, indicando que os efeitos da interação não fram tão expressivos no controle genético do $\mathrm{CE}$, fato este corroborado pela elevada estimativa de $\hat{h}_{\bar{X}}^{2}$ que foi de 0,82 (Tabela 6). Estimativas dessa magnitude de $\hat{h}_{\bar{X}}^{2}$ indicam que a variação entre progênies de meios-irmãos foi em grande parte devida às diferenças genéticas entre elas. Magnitudes elevadas de $\hat{h}_{\bar{X}}^{2}$ indicam também que a seleção para o caráter deve ser eficiente. A estimativa do $\hat{\bar{d}}$ para CE foi de 0,85 . Como para a PROL, o intervalo de confiança englobou o valor 1,00, indicando que também para CE, os efeitos de dominância e aditivos foram importantes no controle genético (Tabela 6). Na literatura, a maioria das estimativas do $\hat{\bar{d}}$ para CE foram de magnitudes semelhantes às relatadas nesta pesquisa (Gardner et al., 1953; Gardner \& Lonquist, 1959; Moll et al., 1964; Han \& Hallauer, 1989; Wolf et al., 2000). Em alguns destes trabalhos, os autores avaliaram a geração $F_{2}$ e gerações após alguns ciclos de recombinação. Moll et al. (1964) verificaram redução na estimativa do $\hat{\bar{d}}$ de 1,12 na geração $F_{2}$ para 0,66 na geração " $F_{8}$ ", para cruzamento envolvendo as linhagens NC7 e CI21. Para o outro cruzamento avaliado (NC33 x K64), a redução foi de 0,86 na geração $F_{2}$ para 0,55 na geração " $F_{8}$ ". Gardner \& Lonquist (1959) avaliando 2 amostras de progênies do cruzamento entre as linhagens M 14 e L-187-2, verificaram uma redução no $\hat{\bar{d}}$ da amostra 1 de 0,58 na geração $F_{2}$ para 0,43 na gração " $F_{8}$ ", e na amostra 2 , uma redução de 1,11 na geração $F_{2}$ para 0,71 na geração "F8". Estes resultados indicam que o desequilíbrio de ligação presente na geração $\mathrm{F}_{2}$ pode estar causando viéses nas estimativas de $\hat{\sigma}_{A}^{2}$ e $\hat{\sigma}_{D}^{2}$.

Os componentes $\hat{\sigma}_{A}^{2}$ e $\hat{\sigma}_{D}^{2}$ para DE foram $20,23 \times 10^{-3}\left(\mathrm{~cm} \mathrm{esp}^{-1}\right)^{2}$ e $3,69 \times 10^{-3}$ $\left(\mathrm{cm} \operatorname{esp}^{-1}\right)^{2}$, respectivamente (Tabela 6). Neste caso, a $\hat{\sigma}_{A}^{2}$ é significativamente superior a 
$\hat{\sigma}_{D}^{2}$, indicando predominância dos efeitos aditivos no controle genético do DE. As estimativas dos componentes de variância genética foram condizentes com os apresentados na literatura (Gardner \& Lonquist, 1959; Moll et al., 1964; Han \& Hallauer, 1989; Wolf et al., 2000). As interações desses componentes com os ambientes $\left(\hat{\sigma}_{A E}^{2} \mathrm{e}\right.$ $\hat{\sigma}_{D E}^{2}$ ) mostraram-se de pequena magnitude quando comparados aos seus respectivos componentes de $\hat{\sigma}_{A}^{2}$ e $\hat{\sigma}_{D}^{2}$, indicando pequeno efeito da interação dos efeitos genéticos com ambientes para o caráter DE (Tabela 6). Nos trabalhos realizados por Han \& Hallauer, (1989) e Wolf et al. (2000) também foi verificado resultado similar. Corroborando com o fato da pequena interação do DE com ambientes e o elevado número de ambientes avaliados, a estimativa de $\hat{h}_{\bar{X}}^{2}$ foi de 0,84 (Tabela 6). Wolf et al. (2000) obtiveram estimativa de $\hat{h}_{\bar{X}}^{2}$ de 0,75 , estando estes resultados condizentes com os apresentados na literatura.

$\mathrm{O}$ valor estimado do $\hat{\bar{d}}$ para $\mathrm{DE}$ foi de 0,60 (Tabela 6). Este valor indica a presença de dominância parcial dos genes responsáveis pelo controle genético do DE, isto é, predominância dos efeitos aditivos no controle genético deste caráter. Na literatura, foram apresentadas diversas estimativas de $\hat{\bar{d}}$ para germoplasma de origem temperada, semelhantes às obtidas neste trabalho, indicando que em germoplasma de origem tropical os efeitos aditivos também são importantes no controle genético do $\mathrm{DE}$ (Robinson et al., 1949; Gardner et al., 1953; Gardner \& Lonquist, 1959; Moll et al., 1964; Wolf et al., 2000).

As estimativas $\hat{\sigma}_{A}^{2}$ e $\hat{\sigma}_{D}^{2}$ para NFI foram $60,41 \times 10^{-2}\left(\mathrm{n}^{\mathrm{o}} \text { fil. }\right)^{2}$ e de $4,40 \times 10^{-2}$ $\left(n^{0}\right.$ fil. $^{2}$, respectivamente. Não se verificou sobreposição dos intervalos de confiança destes componentes, indicando que estes foram diferentes significativamente entre si (Tabela 6). A magnitude dos componentes de $\hat{\sigma}_{A}^{2}$ e $\hat{\sigma}_{D}^{2}$ apresentadas na literatura foram similares às obtidas neste trabalho, confirmando a predominância dos efeitos aditivos em relação aos de dominância no controle genético do NFI (Han \& Hallauer, 1989; Holthaus 
\& Lamkey, 1995; Malvar et al., 1996; Wolf et al., 2000). Os componentes $\hat{\sigma}_{A E}^{2}$ e $\hat{\sigma}_{D E}^{2}$ apresentaram magnitudes pequenas quando comparados com suas respectivas estimativas de $\hat{\sigma}_{A}^{2}$ e $\hat{\sigma}_{D}^{2}$, e não diferiram significativamente entre si, já que ocorreu uma sobreposição dos intervalos de confiança (Tabela 6). Estes resultados foram concordantes com os apresentados na literatura, em que os efeitos da interação com ambientes influenciaram pouco o controle genético do caráter NFI (Han \& Hallauer, 1989; Wolf et al., 2000). A estimativa da $\hat{h}_{\bar{X}}^{2}$ foi de 0,89 , o que corrobora que no controle genético do NFI os efeitos da interação com ambientes foram de pequena magnitude (Tabela 6). A estimativa do $\hat{\bar{d}}$ para o NFI foi de 0,38 (Tabela 6), semelhante à relatada por Wolf et al. (2000), cujo valor foi $\hat{\bar{d}}=0,32$. Estas estimativas indicam que no controle genético do NFI houve uma predominância dos efeitos aditivos. Han \& Hallauer (1989) obtiveram estimativas de $\hat{\bar{d}}$ para NFI, em populações $\mathrm{F}_{2}$ e em populações após cinco ciclos de recombinação ao acaso. Os valores estimados foram de 0,28 e 0,18 , respectivamente. Os autores observaram uma redução no $\hat{\bar{d}}$, o que pode ser devido ao desequilíbrio de ligação e predominância dos efeitos aditivos.

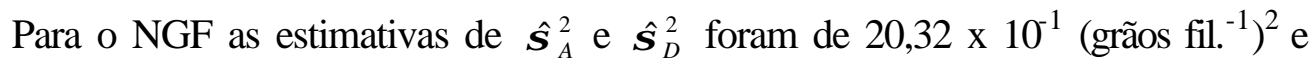
$11,00 \times 10^{-1}$ (grãos fil. $\left.^{-1}\right)^{2}$, respectivamente. Os intervalos de confiança construídos para estes componentes não se sobrepuseram, indicando que estes componentes foram significativamente diferentes. As interações destes componentes com ambientes, mostraram-se inferiores às suas respectivas estimativas de $\hat{\sigma}_{A}^{2}$ e $\hat{\sigma}_{D}^{2}$, o que, juntamente com a estimativa da $\hat{h}_{\bar{X}}^{2}$ de 0,72 , indicaram pequena interação dos efeitos genéticos com ambientes no controle genético do NGF (Tabela 6). A estimativa do $\hat{\bar{d}}$ foi de 1,04, porém, os limites inferiores e superiores dos intervalos de confiança foram de 0,87 a 1,24 , respectivamente, indicando que tanto os efeitos aditivos quanto dominantes foram importantes no controle genético do NGF (Tabela 6). Na literatura, estimativas de $\hat{\sigma}_{A}^{2}$, 
$\hat{\sigma}_{D}^{2}$, e de $\hat{\bar{d}}$, são escassas, o que dificulta a discussão. Vidal-Martínez et al. (2001) estimaram os componentes de médias para NGF. Segundo estes autores, somente os efeitos de dominância mostraram-se significativos. Porém, em estudos de componentes de médias pode ocorrer um cancelamento dos efeitos aditivos e dominantes, pois estes podem ser bidirecionais. Leng (1954) e Cardoso (1999) obtiveram resultados indicando a importância dos efeitos de dominância para NGF. Porém, os resultados apresentados na literatura e obtidos neste trabalho, indicam que os efeitos de dominância devem ser importantes no controle genético do NGF.

Considerando o caráter P500, as estimativas de $\hat{\boldsymbol{\sigma}}_{A}^{2}$ e $\hat{\boldsymbol{\sigma}}_{D}^{2}$ foram de 99,79 gramas $^{2}$ e 20,71 gramas $^{2}$, respectivamente, e diferiram significativamente entre si, uma vez que os intervalos de confiança das mesmas não se sobrepuseram. $\mathrm{O}$ componente $\hat{\sigma}_{D E}^{2}$ não foi significativamente diferente de zero $(P \leq 0,05)$, indicando que os efeitos de dominância não interagiram com os ambientes. $\mathrm{O}$ componente $\hat{\sigma}_{A E}^{2}$ foi significativo $\mathrm{e}$ apresentou magnitude de 28,80 gramas $^{2}$, ou seja, os efeitos aditivos foram afetados pelas condições ambientais. Porém, quando comparada com a $\hat{\sigma}_{A}^{2}$, esta interação não foi tão expressiva. As estimativas dos componentes da variância genética indicaram a predominância dos efeitos aditivos no controle genético do P500 (Tabela 6). Em um programa de melhoramento, caracteres sob controle predominantemente de efeitos aditivos favorecem a seleção, isso porque os efeitos aditivos representam os efeitos médios dos alelos.

As referências a respeito de estimativas dos componentes de variância genética de P500 são escassas. Os trabalhos referem-se a estimativas de componentes de variância genética do peso de grãos, obtidos a partir de 300 ou 1000 grãos (Holthaus \& Lamkey, 1995; Malvar et al., 1996). Nestas pesquisas, as populações adotadas não foram originadas de linhagens endogâmicas, isto é, a frequiência alélica da população era diferente de 0,5 , o que torna a estimativa da variância aditiva função dos efeitos aditivos e de dominância. Apesar disso, houve semelhança entre os resultados obtidos, havendo 
predominância dos efeitos aditivos e pequeno efeito dos ambientes nos componentes genéticos, principalmente nos efeitos de dominância.

A estimativa da $\hat{h}_{\bar{X}}^{2}$ para P500 foi de 0,72 , indicando que a variância genética entre as progênies de meios-irmãos explicaram a maior parte da variância fenotípica e confirmando que os efeitos da interação com ambientais foram pouco expressivos no controle genético deste caráter (Tabela 6). Holthaus \& Lamkey (1995) e Malvar et al. (1996) obtiveram estimativas de $\hat{h}_{\bar{X}}^{2}$ semelhantes a esta. A estimativa de $\hat{\bar{d}}$ para P500 foi de 0,64 , indicando predominância dos efeitos de dominância no controle genético do P500. Na literatura não foram encontradas estimativas de $\hat{\bar{d}}$ para peso do grão, o que impede a comparação dos resultados.

\subsubsection{Número de ramificações do pendão}

As estimativas dos componentes $\hat{\sigma}_{A}^{2}$ e $\hat{\sigma}_{D}^{2}$ do caráter RP foram de 41,68 x $10^{-1}$ $(\text { ram. pendão })^{-1}$ e $5,20 \times 10^{-1}$ (ram. pendão $\left.{ }^{-1}\right)^{2}$, respectivamente. Os intervalos de confiança para estes componentes demonstraram que eles foram significativamente diferentes (Tabela 6). Essas estimativas foram semelhantes às reportadas por Geraldi et al. (1985). Com relação à interação com os ambientes, somente a $\hat{\sigma}_{A E}^{2}$ mostrou-se significativamente diferente de zero $(P \leq 0,05)$ (Tabela 6), ou seja, apenas os efeitos aditivos interagiram com os ambientes. Apesar da significância da $\hat{\sigma}_{A E}^{2}$, sua magnitude foi pequena comparada à magnitude de $\hat{\sigma}_{A}^{2}$.

A estimativa do coeficiente de herdabilidade foi 0,88 , indicando que os efeitos de interação com ambientes e os efeitos ambientais influenciaram pouco o controle genético do caráter. $\mathrm{Na}$ literatura, há poucos trabalhos visando estudar o controle genético do caráter RP. Mock \& Schuetz (1974) estimaram componentes de médias a partir dos genitores e das gerações $F_{1}, F_{2}$ e $F_{3}$, e concluíram que: 1) o caráter RP apresenta herança quantitativa; 2) o maior número de ramificações do pendão é 
dominante em relação ao menor; 3) não se verificou efeito materno; 4) houve predominância dos efeitos aditivos sobre os de dominância; 5) alta herdabilidade do caráter, indicando que a seleção pode ser eficiente para RP. Os resultados obtidos no presente trabalho são concordantes com os obtidos por Mock \& Schuetz (1974), principalmente quanto à predominância dos efeitos aditivos e elevada herdabilidade. Outros trabalhos estudando o número de ramificações do pendão encontraram estimativas elevadas de herdabilidade (Smith et al., 1982; Geraldi et al., 1985; Souza Júnior et al., 1985), além de verificar um pequeno efeito da interação dos efeitos genéticos com ambientes. O valor da estimativa do $\hat{\bar{d}}$ de 0,50 , indica a ocorrência de dominância parcial. Não há estimativas de $\hat{\bar{d}}$ na literatura para RP, inviabilizando comparações de resultados.

\subsection{Correlações entre caracteres}

A apresentação e discussão dos coeficientes de correlações obtidos neste trabalho serão apresentadas em três sub-itens. Inicialmente, serão abordadas as correlações envolvendo PG, seguida das correlações entre os componentes da produção e, finalizando, com as correlações do caráter RP com os demais caracteres.

A presença de correlação entre dois caracteres é função de efeitos genéticos e ambientais, sendo a correlação genética função do desequilíbrio de ligação e/ou efeito pleiotrópico dos genes. O conhecimento das magnitudes das correlações entre os caracteres é importante em um programa de melhoramento, pois possibilita prever a alteração dos caracteres com a atuação da seleção, visto que, no melhoramento visa-se aprimorar diversos caracteres simultaneamente (Vencovsky \& Barriga, 1992). Outra implicação, diz respeito à possibilidade de se estimar a resposta correlacionada à seleção, isto é, o efeito da seleção em $y$, selecionando-se o caráter $x$. A seleção para o caráter $y$ pode ser mais eficiente quando pratica-se seleção em $x$, isto é $R C_{y, x}>G_{S y}$, em que $R C_{y, x}$ é a resposta correlacionada em $y$, selecionando em $x$, e $G_{S y}$ é o ganho com a 
seleção em y. Para que isto ocorra, o caráter secundário $(x)$ deve ter herdabilidade mais alta que o caráter principal (y), e a correlação entre eles deve ser alta (Falconer \& Mackay, 1996).

\subsubsection{Correlações genéticas e fenotípicas envolvendo PG}

Neste trabalho, a precisão experimental e o grande número de pares de progênies avaliadas (250), e conseqüentemente, o elevado número de graus de liberdade, permitiram a detecção de coeficientes de correlação fenotípica $\hat{r}_{\bar{F}}$ significativas a partir de $|0,13|$. As estimativas de correlações fenotípicas entre médias de progênies $\left(\hat{r}_{\bar{F}}\right)$ apresentaram intervalo de variação de $0,12^{\text {ns }}$ (PG x NFI) a $0,48^{* *}$ (PG x DE). Os caracteres que apresentaram estimativas significativas de $\hat{r}_{\bar{F}}$ com PG foram PROL $\left(0,46^{* *}\right), \operatorname{DE}\left(0,48^{* *}\right), \operatorname{CE}\left(0,16^{* *}\right), \operatorname{NGF}\left(0,42^{* *}\right)$ e P500 $\left(0,16^{* *}\right)$. Não se verificou $\hat{r}_{\bar{F}}$ significativa entre PG e os caracteres NFI e RP. As estimativas de correlações genéticas $\left(\hat{r}_{g}\right)$ foram de magnitudes similares às de $\hat{r}_{\bar{F}}$, e o intervalo de variação foi de 0,12 (PG X NFI) a 0,66 (PG x NGF). Estimativas superiores a 0,30 para $\hat{r}_{g}$, foram obtidas entre PG e os seguintes caracteres: PROL $(0,56)$, DE $(0,57)$, CE $(0,39)$, NGF $(0,66)$ e P500 $(0,31)$. As estimativas de coeficientes de correlação genética aditiva $\left(\hat{r}_{a}\right)$ também apresentaram magnitudes similares as obtidas para $\hat{r}_{\bar{F}}$ e para $\hat{r}_{g}$. As estimativas de $\hat{r}_{a}$ apresentaram intervalo de variação de 0,08 (PG x RP) a 0,52 (PG com DE e NGF). Estimativas elevadas de $\hat{r}_{a}$ foram obtidas entre PG e os caracteres PROL $(0,51)$, DE $(0,52)$ e NGF (0,52). As demais estimativas de $\hat{r}_{a}$ foram de pequena magnitude, 0,12 (PG x DE), 0,13 (PG x NFI), 0,08 (PG x RP) e 0,11 (PG x P500). A similaridade de magnitude verificada entre as estimativas de $\hat{r}_{a}$ e $\hat{r}_{g}$ da PG com PROL, DE e NGF, indicaram que os efeitos aditivos foram os principais responsáveis pela presença de correlação genética. As estimativas de $\hat{r}_{g}$ entre PG e os caracteres CE $\left(\hat{r}_{g}=0,39\right)$ e P500 $\left(\hat{r}_{g}=0,31\right)$ não foram 
muito próximas dos valores estimados da $\hat{r}_{a}$, que forneceram 0,12 para PG x CE e 0,11 para PG x P500. Esta diferença observada entre as estimativas de $\hat{r}_{a}$ e $\hat{r}_{g}$, indica que os efeitos não-aditivos também contribuíram para a $\hat{r}_{g}$ envolvendo estes caracteres.

Para a maioria dos caracteres, as estimativas de $\hat{r}_{g}$ e $\hat{r}_{\bar{F}}$ apresentaram magnitudes similares, o que indica que a interação com ambientes e os efeitos ambientais foram pouco expressivos para a correlação entre estes caracteres. Este resultado é concordante com os obtidos com os parâmetros genéticos, em que o efeito da interação entre efeitos genéticos e ambientes sobre os caracteres analisados foi pequeno. Não se verificou correlação significativa entre PG e os caracteres RP e NFI, indicando que a seleção para um desses caracteres não altera a expressão do outro (Tabela 7).

No melhoramento de plantas de espécies de reprodução sexuada, a seleção é realizada com base no efeito médio dos alelos, isto é, efeito aditivo. Os resultados obtidos neste trabalho mostram que a seleção para PG acarreta aumento da PROL, do diâmetro da espiga (DE) e do número de grãos por fileira (NGF).

Estimativas elevadas de $\hat{r}_{a}$ e $\hat{r}_{g}$ entre PG e PROL foram reportadas por Robinson et al. (1951), Souza Júnior et al. (1985), Lemos et al. (1992), Holthaus \& Lamkey (1995) e Arias et al. (1999). Em levantamento de literatura realizado por Hallauer \& Miranda Filho (1988), os autores apresentaram estimativa de $\hat{r}_{g}$ entre PG e PROL de 0,43, sendo esta a média de 16 estimativas. Porém, em alguns destes trabalhos, as estimativas de $\hat{r}_{g}$ foram obtidas a partir de diferentes tipos de progênies como meiosirmãos, progênies $S_{1}$ e $S_{2}$, o que dificulta identificar qual o tipo de efeito predominante envolvido na $\hat{r}_{g}$. Nesta pesquisa, assim como nas de Robinson et al. (1951), Souza Júnior et al. (1985) e Holthaus \& Lamkey (1995), verificourse que $\hat{r}_{g}$ foi de magnitude similar a $\hat{r}_{a}$, indicando que os efeitos aditivos pleiotrópicos foram os predominantes para esta associação. 
Assim como neste trabalho, Robinson et al (1951), Obilana et al. (1979), Sampaio (1986) e Grombacher et al. (1989), também estimaram correlações aditivas e fenotípicas significativas entre PG e os caracteres CE e P500. Porém, outros trabalhos apresentados na literatura obtiveram resultados diferentes (Tyagi et al., 1988; Khanday \& Thakur, 1990; Holthaus \& Lamkey, 1995; Arias et al., 1999). Esta discrepância apresentada na literatura indica que a associação de PG com os caracteres CE e P500 depende também da origem do germoplasma e das populações.

\subsubsection{Correlações genéticas e fenotípicas entre os componentes da produção}

As estimativas do coeficiente de correlação fenotípica $\left(\hat{r}_{\bar{F}}\right)$ variaram de $-0,41^{* *}$ (NFI x P500) a $0,61^{* *}$ (NFI x DE). Dentro deste intervalo de variação, foram obtidas 8 estimativas significativas de $\hat{r}_{\bar{F}}$, sendo 3 destas superiores a $|0,30|$, as quais foram $0,61^{* *}$ para NFI x DE, $0,50^{* *}$ para NGF $x \mathrm{CE}, \mathrm{e}-0,41^{* *}$ para NFI x P500. As demais estimativas de $\hat{r}_{\bar{F}}$ significativas e inferiores a $|0,30|$ foram encontradas entre os componentes PROL x NFI $\left(-0,13^{*}\right)$, DE x P500 $\left(0,16^{*}\right)$, NFI x CE $\left(-0,17^{*}\right)$, CE x P500 $\left(0,24^{* *}\right)$ e P500 x NGF $\left(-0,16^{* *}\right)$ (Tabela 7).

As correlações aditivas $\left(\hat{r}_{a}\right)$ apresentaram intervalo de variação de $-0,46$ (NFI x P500) a 0,63 (NFI x DE). As estimativas de $\hat{r}_{a}$ foram similares às obtidas para $\hat{r}_{\bar{F}}$. Estimativas de $\hat{r}_{a}$ superiores a $|0,30|$ foram obtidas entre os caracteres CE x NGF $(0,46)$, NFI x DE $(0,63)$ e NFI x P500 $(-0,46)$, como verificado para $\hat{r}_{\bar{F}}$. A correlação genética $\left(\hat{r}_{g}\right)$ também apresentou magnitudes similares às obtidas para $\hat{r}_{\bar{F}}$ e $\hat{r}_{a}$, e o intervalo de variação para $\hat{r}_{g}$ foi de -0,41 (NFI x P500), a 0,61 (CE x NGF e DE x NFI). Estimativas de coeficientes de correlação genética superiores a $|0,30|$ foram obtidas entre os componentes CE e NGF $(0,61)$, DE e NFI $(0,61)$, NFI e P500 $(-0,41)$ e CE e P500 $(0,33)$ (Tabela 4). A similaridade verificada entre as estimativas de $\hat{r}_{g}$ e $\hat{r}_{a}$ indica que os efeitos aditivos foram os principais efeitos responsáveis pela correlação genética. Já as 
similaridades entre as magnitudes da $\hat{r}_{g}$ e $\hat{r}_{\bar{F}}$, mostra que a interação com ambientes e os efeitos ambientais foram de pequena importância para a correlação entre os componentes da produção. De acordo com os resultados, há associações positivas de maior magnitude entre os componentes da produção CE x NGF, DE x NFI e CE x P500, enquanto associação negativa foi encontrada entre NFI e P500.

Como esperado, as estimativas mais elevadas de correlação entre os componentes da produção foram entre os caracteres NGF x CE e NFI x DE. Vários autores reportaram associação entre os caracteres NGF e CE, com $\hat{r}_{\bar{F}}$ variando de 0,52 a 0,86 (Tyagy et al., 1988; Khanday \& Thakur, 1990; Arias et al., 1999), semelhantes às encontradas nesta pesquisa. Entre os caracteres NFI e DE, correlações positivas e elevadas foram relatadas por Grombacher et al. (1989), a partir de quatro populações de milho em diferentes ciclos de seleção recorrente, sendo que as estimativas de $\hat{r}_{\bar{F}}$ variaram de $0,31^{* *}$ a $0,59^{* *}$. Arias et al. (1999) obtiveram estimativas positivas de correlação entre NFI e DE, porém de baixa magnitude, $\hat{r}_{\bar{F}}=0,21$ e $\hat{r}_{g}=0,15$. Holthaus \& Lamkey (1995) obtiveram estimativas de $\hat{r}_{g}$ variando de 0,15 a 0,65 para quatro populações em diferentes ciclos de seleção recorrente. Estes resultados são concordantes com os obtidos neste trabalho, em que se mostrou uma relação direta entre NFI x DE e NGF x CE.

As estimativas de correlações relatadas em outros trabalhos, entre os caracteres P500 e NFI, foram em sua maioria de magnitude similar às obtidas neste trabalho. Tyagi et al. (1988) reportaram que a interação com ambientes alterou a $\hat{r}_{\bar{F}}$, já que em um local a $\hat{r}_{\bar{F}}$ foi de $0,41^{* *}$ e, no outro local foi de $-0,27$. Hallauer \& Miranda Filho (1988) relataram estimativas de correlações genética entre o peso do grão e NFI da ordem de $-0,33$, sendo esta, média de cinco estimativas apresentadas na literatura. Estudando a correlação entre caracteres do milho ao longo de ciclos sucessivos de seleção recorrente, Grombacher et al. (1989) obtiveram estimativas positivas de $\hat{r}_{\bar{F}}$ somente para a população BS9 no ciclo zero de seleção $\left(\hat{r}_{\bar{F}}=0,34^{* *}\right)$. Para a população BS1 e o quarto 
ciclo da população BS9, a $\hat{r}_{\bar{F}}$ foi negativa e variou de $-0,15$ a $-0,57^{* *}$. Malvar et al. (1996) relatam estimativas de $\hat{r}_{a}$ de $-0,53^{*}$ a $-0,60^{*}$. Holthaus \& Lamkey (1995) obtiveram estimativas de $\hat{r}_{\bar{F}}$ variando de $-0,31^{* *}$ a $-0,48^{* *}$ e de $\hat{r}_{g}$ variando de $-0,10$ a $-0,39$. Os resultados obtidos neste trabalho foram concordantes com os apresentados na literatura, isso é, o aumento do número de fileiras de grãos da espiga está inversamente relacionado com o peso do grão.

Neste trabalho a estimativa de $\hat{r}_{g}$ entre os componentes P500 e CE foi de 0,33. As correlações aditivas e fenotípicas foram de magnitude inferior a 0,30 e foram similares. Na literatura, esta associação entre peso do grão e CE foi elatada por alguns autores. Grombacher et al. (1989) apresentaram estimativas de $\hat{r}_{\bar{F}}$ entre peso de 300 grãos e CE variando de 0,04 a 0,39*. Kanday \& Thakur (1990) obtiveram estimativas de $\hat{r}_{\bar{F}}$ de 0,56 entre peso de 1000 grãos e CE. Para as populações de diferentes ciclos de seleção avaliadas por Holthaus \& Lamkey (1995), foram encontradas estimativas de $\hat{r}_{g}$ variando de $-0,20$ a 0,14 . Arias et al. (1999) apresentou estimativa de $\hat{r}_{g}$ de 0,35 , similar a obtida neste trabalho. Desse modo, apesar de alguma divergência quanto aos resultados apresentados na literatura, verifica-se uma predominância de associações positivas entre o peso do grão e CE, porém de baixa magnitude.

\subsubsection{Correlações genéticas e fenotípicas com o número de ramificações do pendão}

As estimativas das correlações aditiva, genética e fenotípica do caráter RP com os componentes da produção, apresentaram magnitudes semelhantes. A $\hat{r}_{a}$ variou de 0,25 (RP x PROL) a 0,34 (RP x NFI). A $\hat{r}_{g}$ apresentou intervalo de variação de $-0,15$ (RP x PROL) a $0,32(\mathrm{RP} \times \mathrm{NFI})$, enquanto a $\hat{r}_{\bar{F}}$ variou de $-0,15^{*}$ (RP x PROL) a $0,31^{* *}$ (RP x NFI). As estimativas de correlação entre os caracteres RP x PROL e RP x NFI, foram as que apresentaram os maiores intervalos de variação para todas as correlações 
estimadas (Tabela 7). Esta similaridade nas magnitudes das estimativas das correlações sugere que os efeitos aditivos foram os principais esponsáveis pela correlação genética e que os efeitos da interação e os efeitos ambientais pouco influenciaram na correlação fenotípica.

As correlações entre o caráter $\mathrm{RP} \times \mathrm{PROL}$ foram negativas e de baixa magnitudes $\left(\hat{r}_{a}=-0,25, \hat{r}_{g}=-0,15\right.$ e $\left.\hat{r}_{\bar{F}}=-0,15^{*}\right)$. Esta associação negativa entre RP x PROL indica que a seleção para a redução do número de ramificações do pendão tenderá a aumentar a prolificidade, o que é vantajoso, pois a prolificidade está associada positivamente com a produção de grãos. Porém, apesar da associação positiva entre PROL x PG, o caráter RP mostrou estimativas positivas, no entanto muito pequenas, de correlações com PG $\left(\hat{r}_{a}=0,08, \hat{r}_{g}=0,12\right.$ e $\left.\hat{r}_{\bar{F}}=0,12^{n s}\right)$ (Tabela 7 . Souza Júnior et al. (1985) obtiveram estimativas negativas de correlações aditiva $\left(\hat{r}_{a}=-0,44\right)$ e fenotípica ( $\left.\hat{r}_{\bar{F}}=-0,32\right)$ entre RP x PG. Resultado semelhante foi relatado por Geraldi et al. (1985), em que as estimativas de $\hat{r}_{a}$ variaram de $-0,50$ a $-0,71$, e $\hat{r}_{\bar{F}}$ de $-0,20$ a $-0,34$. A não detecção de correlações entre RP x PG pode estar relacionada à origem do germoplasma utilizada neste trabalho.

As estimativas de correlações dos caracteres DE e NFI com o caráter RP foram positivas, mas de baixa magnitude ( $\hat{r}_{a}=0,26$ e 0,34 , respectivamente). Estes resultados foram condizentes com o esperado, já que as correlações entre DE e NFI foram elevadas. A associação do caráter RP com DE e NFI indica que a seleção para o aumento de DE e de NFI deverá acarretar aumento do caráter RP.

As estimativas de $\hat{r}_{a}$ e $\hat{r}_{\bar{F}}$ entre RP e os caracteres CE e NGF foram próximas de zero $\left(\hat{r}_{a}=0,07\right.$ e 0,12 , respectivamente). Estas baixas estimativas de correlação aditiva entre RP e os caracteres CE e NGF sugerem que o efeito da seleção para CE e/ou NGF, não deverá alterar significativamente a expressão de RP. 


\subsection{Considerações sobre a análise clássica do delineamento III}

Considerando todos os caracteres, pode-se verificar que os parâmetros genéticos estimados para PG, componentes da produção e RP confirmaram os resultados da análise de variância, evidenciando a variabilidade genética entre as progênies avaliadas. Esta variabilidade foi função da divergência genética entre as linhagens L-14-04B e L-08-05F. Com base nos componentes de variância genética, foram obtidas estimativas de $\hat{\sigma}_{A}^{2}$ significativamente superiores às de $\hat{\sigma}_{D}^{2}$ para os componentes da produção e RP. Para PG, $\hat{\sigma}_{A}^{2}$ e $\hat{\sigma}_{D}^{2}$ não foram significativamente diferentes. A presença significativa da $\hat{\sigma}_{A}^{2}$ para todos os caracteres analisados fornece indícios de que a seleção dos mesmos deve ser eficiente. As estimativas dos parâmetros genéticos destes caracteres apresentaram magnitudes semelhantes às reportadas para estes caracteres em milho. Porém, a maioria dos trabalhos relatados utilizou o delineamento III em germoplasma de origem temperada. Desse modo, a similaridade dos resultados obtidos nesta pesquisa, em relação aos relatados, indica que, no caso de germoplasma tropical, o controle genético dos caracteres analisados é similar ao de germoplasma temperado. Porém, neste trabalho, as estimativas de $\hat{\bar{d}}, \hat{\sigma}_{A}^{2}$ e $\hat{\sigma}_{D}^{2}$ foram obtidas a partir de uma população $\mathrm{F}_{2}$, podendo, conseqüentemente, ser viesadas. Estes viéses são função da covariância entre os efeitos dos locos em desequilíbrio de ligação que controlam o caráter (Comstock \& Robinson, 1952). Diversos trabalhos já evidenciaram que o desequilíbrio de ligação pode causar efeito de pseudo-sobredominância (Gardner \& Lonquist, 1964; Moll et al., 1964; Moreno-Gonzaléz et al., 1975; Han \& Hallauer, 1989; Dudley, 1994).

Salienta-se que, para maioria dos caracteres ocorreu maior interação dos efeitos aditivos com os ambientes que com os efeitos de dominância. Resultados onde se verificou maior interação dos efeitos aditivos com ambientes, para estes mesmos caracteres, foram relatados por outros autores (Obilana et al., 1979; Hallauer \& Miranda Filho, 1988; Han \& Hallauer, 1989; Cockerham \& Zeng, 1996; Wolf et al., 2000). 
As estimativas de correlações aditiva, genética e fenotípica apresentaram magnitudes semelhantes para a maioria dos pares dos caracteres analisados, indicando que os efeitos aditivos foram os principais responsáveis pela ocorrência da associação entre os caracteres. As maiores estimativas de correlações foram verificadas entre os componentes NFI x DE, NGF x CE e NFI x P500, e indica que a seleção para algum destes caracteres deverá afetar o comportamento do outro caráter associado. Resultados concordantes foram relatados por diversos autores (Hallauer \& Miranda Filho, 1988; Tyagy et al., 1988; Khanday \& Thakur, 1990; Holthaus \& Lamkey, 1995; Malvar et al., 1996; Arias et al., 1999).

\subsection{Análise do delineamento III com marcadores moleculares}

A análise do delineamento III com marcadores moleculares foi realizada utilizando-se 140 marcadores microssatélites, aplicando a metodologia proposta por Cockerham \& Zeng (1996). Para todos os marcadores moleculares utilizados na análise, foi detectada pelo menos um efeito significativo $(P \leq 0,05)$ para os coeficientes $\hat{\beta_{1}}, \hat{\beta_{2}}$, $\hat{\beta}_{3}$ e $\hat{\beta}_{4}$, ou suas interações com ambientes. Houve, no mínimo, 109 marcadores associados a QTLs com algum efeito significativo para cada caráter avaliado, sendo que PG apresentou o maior número de marcadores associados a QTLs (127) e PROL o menor número (109). O caráter RP apresentou o maior número (87) de marcadores associados significativamente a QTLs com efeito aditivo $\left(\hat{\beta_{1}}\right)$, enquanto PG apresentou maior número (99) de marcadores significativamente associados a QTLs com efeitos dominantes $\left(\hat{\beta}_{3}\right)$. Os efeitos epistáticos $\hat{\beta_{2}}$ (aditivo $\mathrm{x}$ aditivo e dominante $\mathrm{x}$ dominante) ocorreram em maior número para os caracteres NFI e RP, enquanto os efeitos epistáticos $\hat{\beta_{4}}$ (aditivo $\mathrm{x}$ dominante), foram mais frequientes para o caráter NGF. Verificou-se uma predominância de marcadores associados a QTLs com coeficientes $\hat{\beta}_{1}$ e $\hat{\beta}_{3}$ significativos para todos os caracteres, com exceção do caráter NFI, em que houve 
predominância dos coeficientes $\hat{\beta}_{1}$ e $\hat{\beta}_{2}$, e do caráter NGF, em que $\hat{\beta}_{3}$ e $\hat{\beta}_{4}$ foram os coeficientes predominantes. O caráter PROL apresentou o maior número (26) de coeficientes significativos que interagiram com ambientes, sendo que os efeitos aditivos $\left(\hat{\beta_{1}}\right)$ apresentaram maior número de marcadores associados a QTLs que interagiram com ambientes (16). O caráter NFI apresentou o menor número de marcadores associados significativamente a QTLs que interagiram com ambientes (5) (Tabelas 8 a 13).

Como mencionado anteriormente, as estimativas dos coeficientes de regressão parciais $\left(\hat{\beta}_{1}, \hat{\beta_{2}}, \hat{\beta_{3}}\right.$ e $\left.\hat{\beta_{4}}\right)$ refletem o efeito do QTL associado ao marcador. Este efeito pode ser positivo ou negativo, sendo que o sinal é função da origem do alelo. Uma vez que a linhagem L-14-04B é mais vigorosa e produtiva que a linhagem L-08-05F, esta foi considerada como fonte de alelos favoráveis para o efeito aditivo e dominante sobre os alelos da linhagem L-08-05F. Assim, caso $\hat{\beta}_{1}$ e $\hat{\beta}_{3}$ sejam positivos, os alelos com efeito aditivo favoráveis são oriundos da linhagem L-14-04B, e são dominantes sobre os alelos da linhagem L-08-05F. Sinais negativos para $\hat{\beta}_{1}$ e $\hat{\beta}_{3}$ indicam que os alelos favoráveis são oriundos da linhagem L-08-05F e que estes foram dominantes em relação aos alelos da linhagem L-14-04B. A ocorrência de $\hat{\beta}_{1}$ positivos e $\hat{\beta}_{3}$ negativos, indica que os alelos favoráveis com efeito aditivo provêm da linhagem L-14-04B e que os alelos da linhagem L-08-05F dominam os alelos da linhagem L-14-04B. Neste trabalho, ocorreu uma predominância de $\hat{\beta_{1}}$ negativos para a maioria dos caracteres (PG, PROL, CE, NGF, P500 e RP), indicando que a linhagem L-08-05F contribuiu com a maior parte dos alelos favoráveis com efeito aditivo para o cruzamento. Já para o coeficiente $\hat{\beta}_{3}$, quase a totalidade dos coeficientes foram positivos para os caracteres PG, PROL, DE, CE, P500, e RP, sendo que, para NGF todos $\hat{\beta}_{3}$ foram positivos, mostrando que a linhagem mais produtiva (L-14-04B) foi fonte de alelos dominantes em relação aos alelos da linhagem L-08-05F, e que os alelos dominantes foram oriundos, predominantemente, de apenas uma linhagem (Tabelas 8 a 13). 
A seguir, serão discutidos separadamente os resultados da análise do delineamento III com marcadores moleculares para o caráter PG, para os componentes da produção de grãos (PROL, NGF, NFI, CE, DE e P500) e para o nú mero de ramificações do pendão (RP).

\subsubsection{Produção de grãos}

No caso de PG, foram detectados 127 marcadores associados a QTLs com algum efeito genético significativo, ou seja, pelo menos umas das estimativas de $\hat{\beta_{1}}$, ou $\hat{\beta_{2}}$, ou $\hat{\beta_{3}}$, ou $\hat{\beta_{4}}$ foi significativa para este caráter. O número de marcadores associados a QTLs que interagiram com ambientes foi pequeno, apenas 11 (Tabelas 8 e 12). Cockerham \& Zeng (1996) também observaram poucos marcadores associados a QTLs que interagiram com ambientes, mesmo as progênies tendo sido avaliadas em seis ambientes. No presente trabalho, embora os experimentos tenham sido conduzidos em apenas um local, foram utilizadas três estações experimentais que apresentam tipos diferentes de solo. Além disso, as épocas de semeadura foram distintas e realizadas em dois anos agrícolas, simulando diferentes condições ambientais.

O número de marcadores associados a QTLs com estimativas significativas dos coeficientes $\hat{\beta_{1}}, \hat{\beta_{2}}, \hat{\beta_{3}}$ e $\hat{\beta_{4}}$ foram respectivamente, 60 (42,9\%), 16 (11,4\%), 99 $(70,7 \%)$ e $35(25,0 \%)$, sendo esta percentagem dada pela razão entre o número de estimativas significativas e o total de marcadores (140). Estes resultados indicam que os efeitos de dominância $\left(\hat{\beta}_{3}\right)$ e aditivos $\left(\hat{\beta_{1}}\right)$, devem ser importantes no controle genético da PG. Considerando a epistasia como a soma de $\hat{\beta_{2}}$ e $\hat{\beta_{4}}$, verificou-se $51(36,4 \%)$ marcadores associados a QTLs com efeito significativo para estes coeficientes (Tabela 12). Deve-se comentar que esta metodologia permite detectar a epistasia apenas dos QTLs ligados ao mesmo marcador, estimando apenas parte dos efeitos epistáticos. 
Dentre os $60 \hat{\beta_{1}}$ significativos, 12 apresentaram sinais positivos e 48 sinais negativos. Esta predominância de sinais negativos revelou que a linhagem L-08-05F contribuiu com alelos favoráveis de efeito aditivo para o cruzamento. Já para $\hat{\beta}_{3}$, observou-se resultado inverso, em que 98 coeficientes $\hat{\beta}_{3}$ foram positivos e apenas um negativo, o que indica que os alelos de L-14-04B são dominantes sobre os alelos da linhagem L-08-05F (Tabelas 8 e 12).

$\mathrm{O}$ intervalo de variação de $\hat{\beta_{1}}$ foi de $-5,17 \mathrm{~g} \mathrm{planta}^{-1}$ a $2,45 \mathrm{~g}$ planta $^{-1}$, localizados nos cromossomos 10 e 5, respectivamente. Considerando cada cromossomo, apesar de não possuir nenhum valor positivo, o maior intervalo de variação ocorreu no cromossomo 10, -0,95 g planta $^{-1}$ a $-5,17 \mathrm{~g}$ planta $^{-1}$. O coeficiente $\hat{\beta}_{1}$ apresentou significância para marcadores distribuídos em todos os cromossomos, porém o maior número de marcadores (46,7\%) estão localizados nos cromossomos 1 (11 marc.), 9 (7 marc.) e 10 (10 marc.). Para o coeficiente $\hat{\beta}_{2}$ o intervalo de variação foi de $-0,72 \mathrm{~g}$ planta $^{-1}$ a 0,80 g planta $^{-1}$, localizados nos cromossomos 1 e 7 , respectivamente, e o maior intervalo de variação ocorreu no cromossomo $1\left(-0,72 \mathrm{~g} \mathrm{planta}^{-1}\right.$ a $\left.0,62 \mathrm{~g} \mathrm{planta}^{-1}\right)$. Este coeficiente apresentou maior número de marcadores $(75,0 \%)$ associados a QTLs com efeito significativo nos cromossomos 1 (4 marc.), 4 (5 marc.) e 7 (3 marc.) e seu efeito não foi detectado nos cromossomos 8,9 e 10 . O coeficiente $\hat{\beta}_{3}$ apresentou intervalo de variação de $-0,72 \mathrm{~g} \mathrm{planta}^{-1}$ a $5,73 \mathrm{~g} \mathrm{planta}^{-1}$, localizados nos cromossomos 8 e 10 , respectivamente. No cromossomo 10 encontroutse o maior intervalo de variação para $\hat{\beta}_{3}$, isto é, de $1,29 \mathrm{~g} \mathrm{planta}^{-1}$ a $5,73 \mathrm{~g}$ planta $^{-1}$. Efeitos significativos deste coeficiente foram detectados em todos os cromossomos, porém nos cromossomos 1 (17 marc.), 2 (16 marc.) e 10 (12 marc.), detectourse maior número de marcadores $(45,4 \%)$ associados a QTLs com efeito significativo. O coeficiente $\hat{\beta}_{4}$ apresentou intervalo de variação de 1,19 $\mathrm{g}$ planta $^{-1}$ a $0,84 \mathrm{~g}$ planta $^{-1}$, localizados nos cromossomos 4 e 3 , respectivamente. No cromossomo 3 ocorreu o maior intervalo de variação, $-0,64 \mathrm{~g} \mathrm{planta}^{-1}$ a $0,84 \mathrm{~g} \mathrm{planta}^{-1}$. 
Em todos os cromossomos foram detectados efeitos significativos deste coeficiente, porém nos cromossomos 1 (6 marc.), 4 (4 marc.), 5 (6 marc.) e 9 (7 marc.) foram detectados um maior número $(65,7 \%)$ de coeficientes significativos. A interpretação da distribuição dos efeitos significativos dos QTLs pelo genoma do milho fica um pouco comprometida, pois o número de marcadores em cada cromossomo é diferente e a distância (frequiência de recombinação) entre os marcadores também foi variável. Apesar disto, pode-se verificar que os efeitos encontram-se distribuídos em todos os cromossomos do milho, não havendo uma região de concentração de genes (blocos gênicos) responsáveis pelo controle genético da PG (Tabelas 12 a 14).

Considerando a soma dos coeficientes significativos em módulo, nota-se que os efeitos detectados pelas estimativas significativas do coeficiente $\hat{\beta}_{3}$ (dominância) foram superiores as de $\hat{\beta}$ (aditivo) e aos da soma dos efeitos $\hat{\beta}_{2}$ e $\hat{\beta}_{4}$ (epistáticos). A soma de $\hat{\beta_{3}}$ representou cerca de $60,8 \%$ dos efeitos totais, enquanto o coeficiente $\hat{\beta}_{1}$ representou $30,8 \%$, e os efeitos epistáticos $\left(\hat{\beta}_{2}+\hat{\beta}_{4}\right)$ representaram 8,4\% dos efeitos totais (Figura 2). Esta comparação não é totalmente fidedigna, já que um QTL pode estar ligado a mais de um marcador, o que pode influenciar as estimativas dos coeficientes adjacentes. Apesar disso, este resultado, juntamente com o maior número de coeficientes significativos para $\hat{\beta}_{1}$ e $\hat{\beta}_{3}$, corroboram para que os efeitos de dominância $\left(\hat{\beta_{3}}\right)$ seguidos pelos efeitos aditivos $\left(\hat{\beta_{1}}\right)$ foram mais expressivos no controle genético da PG. Considerando ainda que apenas parte dos efeitos epistáticos são detectados por esta metodologia, estes resultados sugerem que estes efeitos podem ser importantes no controle genético da PG (Figura 2, Tabela 8 e 12). A estimativa da razão entre o módulo do somatório dos efeitos dominantes e o somatório dos efeitos aditivos foi de 1,97, semelhante à estimativa de $\hat{\bar{d}}(1,48)$, obtida com a análise clássica do delineamento III, indicando predominância dos efeitos dominantes no controle genético da PG. Na análise realizada por Cockerham \& Zeng (1996), a razão entre o módulo do somatório dos efeitos dominantes e o somatório dos efeitos aditivos foi de 7,45, resultado este, diferente 
do obtido na análise clássica do delineamento III, porém deve-se salientar que pode ocorrer cancelamento dos efeitos genéticos detectados pelos coeficientes, principalmente dos efeitos aditivos.

Cockerham \& Zeng (1996) utilizaram os dados de Stuber et al. (1992) para ilustrar o uso do delineamento III associado a marcadores moleculares. Stuber et al. (1992) obtiveram, a partir de linhagens de origem temperada, 264 pares de progênies $F_{3}$ retrocruzadas com os genitores. Estas progênies foram avaliadas em seis ambientes e foram genotipadas com o uso de 73 marcadores moleculares. Para PG, Cockerham \& Zeng (1996) detectaram 23\%, 16\%, $93 \%$ e $34 \%$ de marcadores associados, respectivamente, a QTLs com $\hat{\beta}_{1}, \hat{\beta}_{2}, \hat{\beta}_{3}$ e $\hat{\beta}_{4}$ significativos. Os resultados obtidos neste trabalho apresentaram resultado similar, porém com um maior número de coeficientes $\hat{\beta_{1}}$ significativos. Isto pode ser devido ao tipo de germoplasma adotado.

O intervalo de variação obtido por Cockerham \& Zeng (1996) para o coeficiente $\hat{\beta_{1}}$ foi de $-1,17 \mathrm{~g}_{\text {planta }}{ }^{-1}$ a $3,39 \mathrm{~g}$ planta $^{-1}$. Para o coeficiente $\hat{\beta_{2}}$, o intervalo de variação foi de $-7,68 \mathrm{~g}_{\text {planta }}^{-1}$ a $4,28 \mathrm{~g}_{\text {planta }}{ }^{-1}$. As estimativas do coeficiente $\hat{\beta}_{3}$ apresentaram intervalo de variação de $3,42 \mathrm{~g} \mathrm{planta}^{-1}$ a $16,95 \mathrm{~g}$ planta $^{-1}$, e o coeficiente $\hat{\beta_{4}}$ apresentou intervalo de variação de $-4,07 \mathrm{~g}$ planta $^{-1}$ a $2,46 \mathrm{~g}$ planta $^{-1}$. Apenas $\hat{\beta_{1}}$ apresentou variação similar ao obtido neste trabalho, as demais estimativas dos coeficientes obtidas por Cockerham \& Zeng (1996) apresentaram maior amplitude de variação. Esta discrepância nos resultados pode ser devida ao número de marcadores utilizados nas análises. Como os coeficientes representam o somatório dos efeitos dos QTLs associados ao marcador, em análises que utilizam menor número de marcadores pode haver maior número de QTLs associados ao marcador e, conseqüentemente, a estimativa do coeficiente poderá ser maior.

$\mathrm{Na}$ análise realizada por Cockerham \& Zeng (1996), os coeficientes $\hat{\beta_{1}}$ significativos estiveram concentrados nos cromossomos 3 e 4, não estando portanto, distribuídos por todo o genoma. Os efeitos destes coeficientes foram positivos para 14 
marcadores e negativos para 3 marcadores. Estes autores definiram que o sinal positivo indicaria que os alelos favoráveis fossem originários da linhagem B73, mais produtiva per se. No presente trabalho, além da distribuição do coeficiente $\hat{\beta_{1}}$ por todo o genoma, houve predominância de coeficientes negativos (48 num total de 60 significativos). Isto indica que a linhagem L-08-05F, menos produtiva, foi fonte dos efeitos aditivos favoráveis para o cruzamento, fato que não ocorreu no trabalho de Cockerham \& Zeng (1996). A ocorrência de estimativas $\hat{\beta_{1}}$ positivas e negativas indica que os efeitos aditivos devem ser bidirecionais.

Foram encontradas estimativas de $\hat{\beta}_{3}$ significativas em todos os cromossomos, havendo predominância de estimativas positivas (@99\% das estimativas significativas). Cockerham \& Zeng (1996) obtiveram resultados similares, isto é, estimativas significativas de $\hat{\beta}_{3}$ em todos os cromossomos, as quais foram positivas em sua maioria

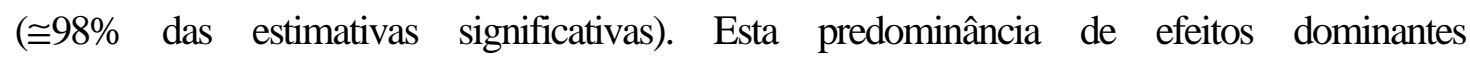
positivos indica a ocorrência de efeitos de dominância predominantemente unidirecionais, fato que explicaria a forte depressão por endogamia deste caráter. Esta coincidência de resultados indica que os alelos das linhagens mais produtivas, L-14-04B e B73, foram dominantes em relação aos alelos das linhagens L-08-05F e Mo17, respectivamente.

Coeficientes significativos responsáveis pelos efeitos epistáticos, $\hat{\beta}_{2}$ e $\hat{\beta_{4}}$, para PG, foram detectados por Cockerham \& Zeng (1996) em 10 (14\%) e 25 (31\%) dos marcadores, respectivamente. Como já comentado, esta metodologia de análise permite detectar apenas parte dos efeitos epistáticos. Apesar disso, com base nos resultados destes autores e nos resultados da presente pesquisa, pôde-se verificar que os efeitos epistáticos foram importantes no controle genético da PG, tanto em germoplasma de origem temperada quanto tropical. Alguns autores detectaram efeitos epistáticos utilizando a abordagem clássica da genética quantitativa (Silva \& Hallauer, 1975; Darrah \& Hallauer, 1972; Gamble, 1962; Sprague et al.; 1962; Hinze \& Lamkey, 2003), porém, 
a maioria dos delineamentos e dos modelos estatístico-genéticos para estimação dos efeitos gênicos condicionados por caracteres quantitativos negligenciam a epistasia no controle genético desses caracteres. A análise do delineamento III associada a marcadores moleculares fornece resultados comparáveis aos obtidos com as análises de média de gerações, em que se obtêm estimativas do somatório dos efeitos dos QTLs segregantes de todo genoma. Embora a interpretação dos resultados de ambas as análises sejam similares, a análise do delineamento III associada a marcadores é mais refinada, pois se refere a QTLs associados a cada marcador individualmente.

Apesar de poucos trabalhos na literatura estimarem \& efeitos epistáticos, têm se evidenciado que estes efeitos têm maior importância em cruzamentos que envolvem linhagens com boa capacidade de combinação. Darrah \& Hallauer (1972) estimaram os efeitos genéticos de quatro diferentes dialelos a partir de linhagens de origens distintas. Os grupos de linhagens foram: 1 - primeiro ciclo, obtidas de população aberta; 2 segundo ciclo, isoladas de cruzamentos específicos ou variedades sintéticas; 3 - linhagens com boas características agronômicas e capacidade de combinação; 4 - linhagens fracas, com relação à capacidade de combinação e desempenho agronômico. Os efeitos epistáticos se mostraram mais pronunciados no dialelo envolvendo as linhagens do segundo ciclo, o que, segundo os autores, justifica-se pelo fato deste grupo ser formado por linhagens selecionadas de materiais melhorados, aumentando as chances de obter combinações favoráveis de epistasia e de dominância.

Sprague et al. (1962), avaliando um grupo de híbridos simples e triplos originados de seis linhagens, detectaram a presença de efeitos epistáticos em alguns cruzamentos e atribuíram estes efeitos à intensa pressão de seleção aplicada na obtenção destas linhagens. Esta seleção seria capaz de capitalizar os efeitos aditivos, dominantes e também os efeitos epistáticos. Os autores comentam que os efeitos epistáticos podem ter maior importância em híbridos com alto potencial produtivo. Velásquez (2000) avaliou, em solos ácidos e não ácidos, cruzamentos obtidos de linhagens com diferentes graus de parentesco e verificaram que os efeitos epistáticos detectados não apresentaram nenhuma conexão com o parentesco das linhagens, e que houve maior detecção de efeitos 
epistáticos em solos não ácidos. Na literatura, não há consenso sobre a importância dos efeitos epistáticos no controle genético de caracteres quantitativos. Apesar disso, alguns trabalhos utilizando técnicas de genética quantitativa clássica e os resultados deste estudo e os obtidos por Cockerham \& Zeng (1996), indicam que estes efeitos não devem ser negligenciáveis, principalmente em cruzamentos com alto potencial produtivo.

\subsubsection{Componentes da produção}

O número de marcadores associados a QTLs com algum efeito significativo para os componentes da produção variou de 109 para PROL, a 126 para NGF. Para os componentes da produção, também foi verificado um pequeno número de marcadores associados a efeitos genéticos que interagiram com os ambientes, sendo que o número de coeficientes significativos variou de 3 para NFI, a 26 para PROL. Como no caso de PG, em que se encontrou elevado número de coeficientes (efeitos) significativos, o mesmo ocorreu para os componentes da produção, indicando que as linhagens adotadas neste trabalho também foram divergentes para estes caracteres, o que vem de encontro aos resultados obtidos na análise clássica do delineamento III (Tabelas 8 a 13).

A presença de efeitos genéticos distribuídos por todo genoma do milho associado ao elevado número de marcadores utilizados nesta pesquisa, permitiu a detecção de coeficientes significativos em todos cromossomos do milho para o conjunto dos caracteres. No entanto, não foram detectados coeficientes significativos em alguns cromossomos para alguns caracteres. Estimativas significativas de $\hat{\beta}_{1}$ ocorreram em todos os cromossomos para os componentes da produção, exceto para o caráter PROL no cromossomo 8 e NGF no cromossomo 9. Estimativas de $\hat{\beta}_{2}$ significativas também apresentaram ampla distribuição pelo genoma, não tendo sido detectas apenas no cromossomo 9, para o caráter PROL. O coeficiente $\hat{\beta}_{3}$ seguiu o mesmo padrão sendo detectado na maioria dos cromossomos, estando ausente apenas no cromossomo 8 para PROL e nos cromossomos 2, 4 e 8 para o caráter NFI. Para o coeficiente $\hat{\beta}_{4}$ não foram 
verificados efeitos significativos no cromossomo 4 para PROL, nos cromossomos 2, 6, e 10 para NFI, no cromossomo 7 para DE e nos cromossomos 3 e 5 para P500 (Tabelas 12 e 13).

Em geral verificourse que os coeficientes $\hat{\beta_{1}}$ e $\hat{\beta}_{3}$ foram os efeitos detectados em maior número para os componentes da produção. Para os caracteres DE e P500, observou-se maior número de $\hat{\beta}_{1}$ significativos, seguidos de $\hat{\beta}_{3}$, enquanto que para PROL e CE detectaram-se maior número de $\hat{\beta}_{3}$ significativos, seguidos de $\hat{\beta}_{1}$. No caso de NGF, houve maior ocorrência de $\hat{\beta}_{3}$ significativos, seguidos de $\hat{\beta}_{4}$, e para NFI, ocorreu predomínio de $\hat{\beta_{1}}$ significativos seguidos de $\hat{\beta_{2}}$ (Tabelas 12 e 13 ). Considerando a soma dos coeficientes em módulo, observourse que para DE, NFI e P500, houve uma maior contribuição dos efeitos aditivos em relação aos demais efeitos. Este resultado é concordante com o obtido na análise clássica do delineamento III, em que as estimativas do $\hat{\bar{d}}$ foram de 0,60, 0,38 e 0,64 para DE, NFI e P500, respectivamente, indicando predominância dos efeitos aditivos no controle genético destes caracteres (Figuras 2 e 3). Muitos resultados apresentados na literatura considerando componentes de médias e variância para os caracteres DE, NFI e P500 são concordantes com os obtidos com a análise do delineamento III associada a marcadores (Robinson et al, 1949; Gardner et al., 1953; Gardner \& Lonquist, 1959; Moll et al., 1964; Han \& Hallauer, 1989; Holthaus \& Lamkey, 1995; Malvar et al., 1996; Wolf et al., 2000).

Os caracteres PROL, CE e NGF apresentaram maior número de marcadores associado ao coeficiente $\hat{\beta}_{3}$, seguido do coeficiente $\hat{\beta}_{1}$ para os caracteres PROL e CE, e do coeficiente $\hat{\beta_{4}}$ para NGF. O somatório dos efeitos dos coeficientes significativos em módulo, mostraram que os efeitos do coeficiente $\hat{\beta}_{3}$ (dominância) foram os mais expressivos no controle genético destes caracteres. No entanto, para NGF, observou-se uma maior ocorrência de $\hat{\beta}_{3}$ significativos seguidos de $\hat{\beta}_{4}$, porém, no somatório em 
módulo, os efeitos significativos de $\hat{\beta_{1}}$ foram superiores a soma dos efeitos significativos da epistasia $\left(\hat{\beta_{2}}\right.$ e $\hat{\beta}_{4}$ ), uma vez que a magnitude dos efeitos $\hat{\beta_{1}}$ são maiores. As estimativas obtidas a partir da análise clássica do delineamento III para o $\hat{\bar{d}}$ foram de 0,81 para PROL, de 0,85 para CE e de 1,04 para NGF. Os intervalos de confiança destas estimativas incluíram o valor 1, indicando a importância dos efeitos de dominância, resultado este, concordante com os obtidos na análise do delineamento III com marcadores moleculares. Trabalhos utilizando a abordagem clássica do delineamento III, confirmam os resultados obtidos com marcadores moleculares, em que verificaram que os efeitos de dominância e aditivos foram importantes no controle genético dos caracteres PROL, CE e NGF (Robinson et al., 1949; Gardner et al, 1953; Gardner \& Lonquist, 1959; Moll et al., 1964; Han \& Hallauer, 1989; Cockerham \& Zeng, 1996; Wolf et al., 2000; Vidal-Martínez et al., 2001).

Os efeitos epistáticos $\left(\hat{\beta}_{2}\right.$ e $\left.\hat{\beta}_{4}\right)$ foram detectados em menor número para a maioria dos caracteres, exceto para os caracteres NGF e NFI. Para NGF, o coeficiente $\hat{\beta_{4}}$ apresentou o segundo maior número de marcadores associados a este coeficiente, e para NFI ambos coeficientes, $\hat{\beta_{2}}$ e $\hat{\beta}_{4}$, foram detectados em grande número, inferior apenas à ocorrência do coeficiente $\hat{\beta}_{1}$. Considerando a soma em módulo dos coeficientes, nota-se que os efeitos epistáticos foram expressivos no controle genético dos componentes da produção, principalmente para os caracteres CE e NFI (Figuras 2 e 3). Como esta metodologia é capaz de detectar apenas os efeitos epistáticos dos QTLs ligados a um mesmo marcador, estes efeitos devem ser responsáveis por uma parcela expressiva no controle genético dos componentes da produção. Os trabalhos com epistasia com componentes da produção são escassos. Eberhart et al. (1966), ao estudarem duas populações de milho (Javis e Indian Chief), não encontraram efeitos significativos de epistasia no controle genético dos caracteres PROL, DE e CE. Porém, em trabalho realizado por Darrah \& Hallauer (1972), utilizando quatro dialelos obtidos 
de linhagens com diferentes características, verificaram a presença de epistasia em todos dialelos para os caracteres NGF, CE, DE e peso de 300 grãos.

Apesar da detecção de coeficientes em todos os cromossomos, observou-se que, para alguns caracteres, alguns cromossomos apresentaram um maior número de coeficientes significativos. Para PROL, 66,0\% dos coeficientes $\hat{\beta}_{1}$ significativos referentes aos marcadores localizados nos cromossomos 2 (9 marc.), 3 (7 marc.), 5 (8 marc.) e 7 ( 7 marc.) e, para o coeficiente $\hat{\beta}_{3}$, detectaram-se $49,2 \%$ dos coeficientes significativos nos marcadores dos cromossomos 1 (14 marc.), 5 (9 marc.) e 10 (7 marc.). Para os coeficientes responsáveis pela detecção da epistasia, detectaram-se $\hat{\beta_{2}}$ significativos em maior quantidade (51,9\%) nos marcadores dos cromossomos 5 (9 marc.) e 6 (5 marc.), e para $\hat{\beta}_{4}$ os efeitos significativos em maior quantidade $(39,1 \%)$ estiveram presentes nos marcadores dos cromossomos 1 (4 marc.) e 3 (5 marc.).

Para DE, detectou-se uma maior quantidade de marcadores associados ao coeficiente $\hat{\beta_{1}}$ nos cromossomos 4 (8 marc.), 5 (15 marc.) e 10 (10 marc.), enquanto que para $\hat{\beta}_{3}$ os marcadores localizados nos cromossomos 1 (10 marc.), 3 (7 marc.) e 10 (12 marc.) foram responsáveis por cerca de 50,9\% do total dos coeficientes significativos. Os efeitos epistáticos estão distribuídos principalmente nos marcadores localizados nos cromossomos 4, 5, 7 e $9\left(\hat{\beta}_{2}\right)$ e 1 e $9\left(\hat{\beta}_{4}\right)$, correspondendo, respectivamente, a 57,5\% e $38,1 \%$ dos coeficientes $\hat{\beta}_{2}$ e $\hat{\beta}_{4}$ significativos.

Os coeficientes $\hat{\beta}_{1}$ do caráter $\mathrm{CE}$ estiveram em maior número $(54,5 \%)$ nos marcadores localizados nos cromossomos 1 (7 marc.), 5 (7 marc.), 7 (7 marc.) e 10 (9 marc.), e o coeficiente $\hat{\beta}_{3}$ foi predominantemente $(50,0 \%)$ detectado nos marcadores dos cromossomos 1 (13 marc.), 2 (14 marc.) e 5 (9 marc.). A epistasia foi detectada principalmente nos marcadores dos cromossomos 2 e $10\left(\hat{\beta}_{2}\right)$, e nos cromossomos 4,5 , 7 e $8\left(\hat{\beta}_{4}\right)$, correspondendo a $37,7 \%$ e a $57,1 \%$ dos coeficientes $\hat{\beta}_{2}$ e $\hat{\beta}_{4}$, respectivamente. 
Para o caráter P500, os cromossomos 1, 2 e 3 foram responsáveis pela localização de $55,2 \%$ dos marcadores associados ao coeficiente $\hat{\beta}_{1}$, e os cromossomos 1 , $2,3,5$ e 8 por $75,0 \%$ dos marcadores associados ao coeficiente $\hat{\beta}_{3}$. O coeficiente $\hat{\beta_{2}}$ foi detectado em maior número nos marcadores dos cromossomos 4 e 9 , responsáveis por $44,4 \%$ dos $\hat{\beta_{2}}$ significativos, e o coeficiente $\hat{\beta_{4}}$ nos marcadores dos cromossomos 2,4 e 7, nos quais $57,9 \%$ dos $\hat{\beta}_{4}$ significativos foram detectados.

Cerca de $41,0 \%$ dos coeficientes $\hat{\beta_{1}}$ significativos para NGF foram detectados nos marcadores dos cromossomos 5 (10 marc.) e 10 (6 marc.), enquanto 51,8\% dos coeficientes $\hat{\beta}_{3}$ significativos foram detectados nos marcadores dos cromossomos 1 (15 marc.), 2 (17 marc.) e 10 (12 marc.). Os efeitos epistáticos apresentaram-se em maior número nos marcadores dos cromossomos 2 e 6 (35,7\% dos $\hat{\beta_{2}}$ significativos) e nos cromossomos 4, 7, 9 e 10 (65\% dos $\hat{\beta}_{4}$ significativos).

Para o caráter NFI, o maior número de marcadores associados ao coeficiente $\hat{\beta}_{1}$ significativos $(56,1 \%)$ foram detectados nos marcadores dos cromossomos 1 (11 marc.), 2 (15 marc.), 4 (10 marc.) e 5 (10 marc.). O coeficiente $\hat{\beta}_{2}$ foi detectado em maior número nos marcadores dos cromossomos 1,2 e $10(48,1 \%)$, e o $\hat{\beta}_{4}$ nos cromossomos 1 e $7(56,3 \%)$. Houve poucas estimativas $\hat{\beta}_{3}$ significativas (10), as quais ocorreram principalmente nos marcadores dos cromossomos 1, 6 e 7 (60\% do total). Apesar da distância (frequiência de recombinação) irregular entre os marcadores e o diferente número de marcadores por cromossomo, com base no exposto, verifica-se que alguns cromossomos concentram QTLs responsáveis pelo controle genético de alguns dos caracteres analisados.

Adotou-se que o sinal positivo do coeficiente $\hat{\beta_{1}}$ indicaria que o alelo favorável fosse oriundo da linhagem L-14-04B e o sinal positivo de $\hat{\beta}_{3}$ indicaria que o alelo da linhagem L-14-04B é dominante em relação ao alelo da linhagem L-08-05F. Para os 
caracteres DE e NFI, ocorreu maior número de coeficientes $\hat{\beta_{1}}$ positivos, indicando que a linhagem L-14-04B contribuiu com a maior parte dos alelos favoráveis para estes caracteres. Porém, para DE notourse um número expressivo de coeficientes $\hat{\beta_{1}}$ negativos, mostrando que a linhagem L-08-05F também foi fonte de alelos favoráveis para este caráter. Para os demais caracteres (PROL, CE, NGF e P500), o número de coeficientes $\hat{\beta}_{1}$ negativos foi superior aos positivos, porém esta diferença foi maior para os caracteres PROL e P500. Este resultado mostra que tanto a linhagens L-14-04B e L08-05F foram fontes de alelos favoráveis para os caracteres CE e NGF, e que para os caracteres PROL e P500, houve uma predominância dos alelos favoráveis oriundos da linhagem L-08-05F. Diferente de $\hat{\beta}_{1}$, o coeficiente $\hat{\beta}_{3}$ apresentou sinal positivo para a maioria dos efeitos para todos caracteres, exceto para NFI. Este resultado foi similar ao obtido para PG, o que confirma que a linhagem L 14-04B, foi fonte de alelos dominantes em relação a linhagem L-08-05F. No trabalho realizado por Cockerham \& Zeng (1996), apesar do pequeno número de coeficientes significativos detectados para o número de espigas (8), todos foram positivos. Os demais caracteres avaliados por Cockerham \& Zeng (1996) - produção de grãos, altura da espiga, área da folha da espiga, das para florescimento masculino e umidade dos grãos - apresentaram coeficientes $\hat{\beta}_{3}$ predominantemente com apenas um sinal (positivo ou negativo), ou seja, predominância de unidirecionalidade dos efeitos. Silva (2002) obteve resultado smilar para os caracteres altura da espiga, altura da planta, posição relativa da espiga, intervalo de florescimento, florescimento masculino e florescimento feminino. Nas análises deste autor, todos os coeficientes $\hat{\beta}_{3}$ apresentaram apenas um sinal (positivo ou negativo). Assim, todos estes resultados indicam a ocorrência de efeitos de dominância unidirecionais para a maioria dos componentes da produção, o que explicaria a forte depressão por endogamia no milho para estes caracteres.

Para PROL, o coeficiente $\hat{\beta_{1}}$ apresentou a maior amplitude de variação dos coeficientes significativos, $-26,01 \times 10^{-3}$ esp. planta $^{-1}$ a $16,43 \times 10^{-3}$ esp. planta ${ }^{-1}$. Para os 
demais caracteres, o coeficiente $\hat{\beta}_{1}$ também apresentou maior amplitude de variação, seguido de $\hat{\beta}_{3}$ para DE, CE, NGF e P500 e de $\hat{\beta_{2}}$ para NFI. As estimativas dos coeficientes responsáveis pela detecção da epistasia, $\hat{\beta}_{2}$ e $\hat{\beta}_{4}$, apresentaram menor amplitude. Cockerham \& Zeng (1996) também verificaram um maior intervalo de variação para o coeficiente $\hat{\beta_{1}}$.

\subsubsection{Número de ramificações do pendão}

Para o caráter número de ramificações do pendão (RP), 125 marcadores $(89,29 \%)$ apresentaram significância para pelo menos um dos coeficientes $\hat{\beta}_{1}, \hat{\beta}_{2}, \hat{\beta}_{3}$ e/ou $\hat{\beta_{4}}$. O número de coeficientes que interagiram com ambientes foi pequeno (8). Este elevado número de coeficientes significativos indica, como verificado na análise clássica do delineamento III, que as linhagens adotadas neste trabalho, também foram divergentes para este caráter (Tabelas 11 e 13).

Os coeficientes apresentaram efeitos significativos em todos cromossomos, exceção verificada para $\hat{\beta}_{4}$ no cromossomo 5. O coeficiente $\hat{\beta}_{1}$ apresentou o maior número marcadores associados a QTLs com coeficientes significativos (87), além de 8 interações com ambientes. Nos cromossomos 2 (14 marc.), 4 (14 marc.) e 5 (13 marc.) foram identificados o maior número de coeficientes significativos $\hat{\beta_{1}}$, perfazendo $47,5 \%$ do total. $\mathrm{O}$ coeficiente $\hat{\beta}_{3}$ apresentou o segundo maior número de coeficientes significativos (55), estando a maior parte destes coeficientes $(50,9 \%)$ relacionados a marcadores localizados nos cromossomos 2 (8 marc.), 5 (10 marc.) e 10 (10 marc.). Os efeitos epistáticos detectados pelo coeficiente $\hat{\beta_{2}}$ apresentaram 54 efeitos significativos, sendo que nos cromossomos 4, 5 e 6 estiveram localizados 46,3\% dos marcadores relacionados a estes coeficientes. $\mathrm{O}$ coeficiente $\hat{\beta}_{4}$ apresentou 25 marcadores associados 
a QTLs com efeito significativo, sendo que 40,0\% destes efeitos estiveram nos marcadores localizados nos cromossomos 1 e 7 (Tabelas 11 e 13).

Das 87 estimativas $\hat{\beta_{1}}$ significativas, 42 foram positivas e 45 negativas. Este resultado indica que tanto a linhagem L-14-04B quanto a linhagem L-08-05F, contribuiu com alelos favoráveis de efeitos aditivos para o cruzamento. $\mathrm{O}$ coeficiente $\hat{\beta}_{3}$ apresentou 53 estimativas positivas e 2 negativas, ou seja os alelos da linhagem L-14-04B foram dominantes em relação aos alelos da linhagem L-08-05F, para a maioria dos coeficientes significativos.

Considerando a distribuição do somatório em módulo dos coeficientes significativos, obteve-se resultado concordante com o número de marcadores associados a QTLs com coeficientes significativos, ou seja, o somatório em módulo dos efeitos aditivos $\left(\hat{\beta_{1}}\right)$ foram predominantes, seguidos dos efeitos de dominância $\left(\hat{\beta_{3}}\right)$ e epistáticos $\left(\hat{\beta}_{2}\right.$ e $\left.\hat{\beta}_{4}\right)$ (Figura 3 ). Na análise clássica do delineamento III, obteve-se também predominância dos efeitos aditivos no controle genético do caráter RP, uma vez que a estimativa do grau médio de dominância foi de 0,50 . Nota-se que os efeitos epistáticos também foram importantes no controle genético do caráter RP, visto que esta metodologia detecta apenas parte destes efeitos. Moch \& Schuetz (1974), estimando componentes de médias para RP, encontraram predominância de efeitos aditivos no controle genético deste caráter. Ao estimarem os componentes de média de duas populações de milho, uma originada de linhagens exóticas e outras de linhagens elites do Corn Belt, Vidal-Martínez et al (2001) verificaram que para a população originada de linhagens exóticas, apenas os efeitos de dominância foram significativos, enquanto para a população originada a partir de linhagens elites, ambos os efeitos, aditivos e de dominância, mostraram-se significativos. Apesar das estimativas dos componentes de média estarem sujeitas a um maior cancelamento dos efeitos, principalmente aditivos, pode-se notar uma concordância entre os resultados da presente pesquisa e os obtidos por Moch \& Schuetz (1974) e Vidal-Martínez et al. (2001). 
O coeficiente $\hat{\beta_{1}}$ apresentou o maior intervalo de variação entre os coeficientes estimados, $-57,67 \times 10^{-3}$ (ram. pendão ${ }^{-1}$ ) a $77,90 \times 10^{-3}$ (ram. pendão ${ }^{-1}$ ), sendo a maior variação verificada no cromossomo 10 . O coeficiente $\hat{\beta_{2}}$ apresentou intervalo de variação de $-16,15 \times 10^{-3}$ (ram. pendão ${ }^{-1}$ ) a $9,93 \times 10^{-3}$ (ram. pendão ${ }^{-1}$ ), estando o maior intervalo de variação localizado no cromossomo 6. Para o coeficiente $\hat{\beta}_{3}$, o intervalo de variação foi de $-12,21 \times 10^{-3}$ (ram. pendão ${ }^{-1}$ ) a $22,81 \times 10^{-3}$ (ram. pendão ${ }^{-1}$ ), sendo que no cromossomo 5 , foi verificado o maior intervalo de variação.

\subsection{Considerações finais}

A estratégia adotada em um programa de melhoramento é delineada com base nas informações a respeito do controle genético dos caracteres de importância agronômica, que geralmente são poligênicos. Os delineamentos propostos por Comstock \& Robinson (1948, 1952) para estimação dos componentes de variância genética dos caracteres quantitativos, contribuíram de maneira expressiva para o entendimento dos caracteres quantitativos. Dentre os delineamentos propostos, o delineamento III permite estimar os componentes da variância genética e o grau médio de dominância. A desvantagem destas abordagens, é que representam o somatório dos genes segregantes responsáveis pelo controle genético do caráter, além de não permitirem estimar os efeitos epistáticos. Com o advento e aprimoramento de marcadores moleculares nas últimas 3 décadas, está sendo possível individualizar os efeitos de regiões cromossômicas no controle genético de caracteres importantes. Cockerham \& Zeng (1996) propuseram uma metodologia associando o delineamento III com marcadores moleculares. Esta metodologia permite estimar os efeitos aditivos, dominantes e epistáticos dos QTLs ligados a marcadores moleculares.

$\mathrm{Na}$ presente pesquisa, os resultados obtidos a partir da análise clássica do delineamento III mostraram que as linhagens adotadas como genitoras das progênies $\mathrm{F}_{2}: 3$ foram divergentes para os caracteres avaliados. A boa precisão experimental obtida no 
experimento resultou na obtenção de intervalos de confiança pequenos para a maioria dos componentes de variância e graus médios de dominância. Os caracteres PROL, CE e NGF apresentaram estimativas de $\hat{\bar{d}}$ em que o intervalo de confiança englobou o valor 1,0 , indicando que tanto os efeitos de dominância quanto os aditivos foram importantes no controle genético destes caracteres. As estimativas do grau médio de dominância mostrou predominância dos efeitos aditivos $(\hat{\bar{d}}<1,0)$ para os caracteres DE, NFI, P500, e RP. Para o caráter PG, a estimativa do grau médio de dominância foi de 1,48, indicando a presença de sobredominância para este caráter. Porém, estimativas de $\hat{\sigma}_{A}^{2}$ e $\hat{\sigma}_{D}^{2}$ obtidas a partir de populações $F_{2}$ podem estar viesadas devido ao desequilíbrio de ligação, gerando estimativas $\hat{\bar{d}}>1,0$, ou seja, pseudo-sobredominância (Comstock \& Robinson, 1952). Apesar disso, a hipótese de sobredominância não pode ser descartada. Foi detectada baixa interação dos componentes de variância genética com os ambientes. As estimativas de $\hat{\sigma}_{A E}^{2}$ e $\hat{\sigma}_{D E}^{2}$ foram significativas para a maioria dos caracteres analisados, exceto para P500 e RP. Porém, as estimativas de $\hat{\sigma}_{A E}^{2}$ foram, em geral, superiores a $\hat{\sigma}_{D E}^{2}$, indicando maior interação dos efeitos aditivos com os ambientes.

As estimativas de correlações obtidas, mostraram maior associação entre os caracteres PG x PROL, PG x DE, PG x NGF, NFI x DE, RP x NFI, P500 x NFI e CE $x$ P500. A magnitude entre as estimativas de $\hat{r}_{a}, \hat{r}_{g}$ e $\hat{r}_{\bar{F}}$ foram similares para a maioria das estimativas. A similaridade verificada entre $\hat{r}_{a}$ e $\hat{r}_{g}$ indica que os efeitos aditivos foram os principais efeitos responsáveis pela presença da correlação genética e, a similaridade entre as estimativas de $\hat{r}_{g}$ e $\hat{r}_{\bar{F}}$ mostram que a interação com ambientes e os efeitos ambientais foram de pequena importância para associação entre os caracteres. Espera-se que pares de caracteres que apresentem estimativas de correlação elevada, haja um elevado número de marcadores com efeito $\hat{\beta}_{1}$ e/ou $\hat{\beta}_{3}$ significativos em comum. Para os caracteres, PROL, DE e NGF, que apresentaram estimativas elevadas de correlação com PG, o número de marcadores com efeito $\hat{\beta}_{1}$ e/ou $\hat{\beta}_{3}$ significativos em comum foi de 85 , 
98 e 90, respectivamente. Entre os caracteres NFI x DE, RP x NFI, P500 x NFI e CE x P500, que também apresentaram estimativas elevadas de correlações, verificaram-se 77, 73, 81, 73 marcadores com efeitos $\hat{\beta_{1}}$ e/ou $\hat{\beta}_{3}$ significativos em comum, respectivamente. A média de marcadores com efeito $\hat{\beta_{1}}$ e/ou $\hat{\beta}_{3}$ coincidentes foi de 76 , sendo que 28 marcadores foram comuns para todos caracteres. Como esperado, na maioria dos casos em que verificourse correlações elevadas, verificou-se uma maior coincidência de marcadores com efeito $\hat{\beta_{1}}$ e/ou $\hat{\beta}_{3}$.

A análise associando o delineamento III com marcadores moleculares permitiu detectar efeitos genéticos significativos distribuídos em todos os cromossomos do milho para todos caracteres analisados. Para os caracteres PG, PROL, CE e NGF, os coeficientes $\hat{\beta}_{3}$ foram os detectados em maior número, seguidos por $\hat{\beta_{1}}$. Os caracteres DE, RP, P500 e NFI apresentaram coeficientes $\hat{\beta_{1}}$ significativos em maior número, seguido pelo coeficiente $\hat{\hat{\beta}_{3}}$ para RP, P500 e PROL, e $\hat{\beta}_{2}$ para NFI. Os efeitos epistáticos mensurados pelos coeficientes $\hat{\beta}_{2}$ e $\hat{\beta}_{4}$ foram detectados para todos caracteres, encontrando-se distribuídos por todo o genoma.

Alguns marcadores moleculares estiveram significativamente associados a QTLs que apresentaram mais de um efeito significativo simultaneamente. Considerando a ocorrência simultânea de dois coeficientes $\hat{\beta}$ 's significativos associados a um marcador, foi detectado que a ocorrência concomitante de $\hat{\beta}_{1}$ e $\hat{\beta}_{3}$ foi predominante para todos caracteres avaliados. Exceção foi observada para os caracteres NFI e RP, em que a maior ocorrência de coeficientes simultaneamente significativos foi entre $\hat{\beta}_{1}$ e $\hat{\beta_{2}}$. Todas as combinações duas a duas de coeficientes apresentaram marcadores coincidentes (Tabelas 12 e 13). Este fato indica que o marcador está associado a mais de um QTL ou, a um QTL com efeito significativo para dois coeficientes.

A distribuição do somatório dos efeitos dos coeficientes significativos confirmou a importância dos efeitos aditivos e de dominância no controle dos caracteres 
analisados. Verificou-se uma concordância entre os resultados obtidos com a análise clássica do delineamento III e a associação deste delineamento com marcadores moleculares. Observou-se para os caracteres DE, RP, P500 e NFI uma maior importância dos efeitos aditivos que os demais efeitos no controle genético destes caracteres. Enquanto os efeitos de dominância foram predominantes no controle genético dos caracteres PG, PROL, CE e NGF (Figura 2 e 3). Deve-se salientar que, para todos caracteres, os efeitos epistáticos mostraram-se de relativa importância, principalmente para os caracteres CE, PROL, DE e NFI, apesar desta metodologia ser capaz de detectar apenas parte dos efeitos epistáticos.

Neste trabalho, convencionou-se que estimativas positivas de $\hat{\beta}_{1}$ indicariam que os alelos favoráveis seriam provenientes da linhagem L-14-04B, e que estimativas $\hat{\beta}_{3}$ positivas indicariam que os alelos da linhagem L-14-04B seriam dominantes em relação aos alelos da linhagem L-08-05F. Verificou-se uma predominância de coeficientes $\hat{\beta_{1}}$ negativos para os caracteres PG, PROL, CE, P500, indicando que a linhagem L-08-05F foi a principal fonte de alelos favoráveis de efeito aditivo para o cruzamento. Para os caracteres RP, NGF e DE, ambas linhagens contribuíram com alelos favoráveis de efeito aditivo para o cruzamento. A maior parte dos coeficientes $\hat{\beta_{1}}$ para NFI foram positivos, indicando que a linhagem L-14-04B foi a principal fonte de alelos favoráveis para este caráter. $O$ coeficiente $\hat{\beta}_{1}$ também apresentou o maior intervalo de variação para os caracteres analisados. Para todos caracteres, com exceção do NFI, em que houve poucos coeficientes $\hat{\beta}_{3}$ significativos, os alelos da linhagem L-14-04B, com melhor desempenho per se, foram dominantes em relação aos alelos da linhagem L-08-05F, uma vez que houve maior frequiência de estimativas significativas de $\hat{\beta}_{3}$ positivas. Resultado semelhante foi obtido por Cockerham \& Zeng (1996) e Silva (2002) para os caracteres por eles avaliados.

O objetivo principal da associação do delineamento III com marcadores moleculares, proposto por Cockerham \& Zeng (1996), é a estimação dos efeitos 
genéticos dos QTLs ligados a um marcador, e não o mapeamento genético de QTLs. Esta metodologia mostrou-se eficiente na estimação dos efeitos aditivos, dominantes e epistáticos. A abordagem clássica do delineamento III permite obter estimativas dos componentes da variância genética e do grau médio de dominância. $\mathrm{Na}$ análise associando marcadores moleculares, os coeficientes $\hat{\beta}_{1}$ e $\hat{\beta}_{3}$, além de detectarem principalmente os efeitos aditivos e de dominância respectivamente, são funções da frequiência de recombinação $(r)$ e dos efeitos epistáticos $\gamma(a x d)$ e $\phi(d x a)$ para o coeficiente $\hat{\beta_{1}}$, e função de $r$ e dos efeitos epistáticos $\varepsilon$ (axa) para o coeficiente $\hat{\beta}_{3}$. Apesar destas duas metodologias de análises apresentarem limitações nas estimações dos efeitos genéticos, os resultados obtidos por ambas análises foram concordantes. Também, esta análise permite obter estimativas de componentes de médias em regiões localizadas no genoma que podem ser oriundas de um QTL ou de alguns QTLs. Nos delineamentos em que se utilizaram análises de médias de gerações, o que se obtém são valores médios dos componentes de média, cujos valores podem ser cancelados devido a bidirecionalidade de efeitos e, portanto, não serem detectados. A análise do delineamento III com marcadores moleculares reduz este efeito do cancelamento por particularizar regiões do genoma.

No site www.agron.missouri.edu é apresentado um resumo dos trabalhos publicados com mapeamento de milho. Em levantamento realizado em 08/01/03, haviam sido mapeados 71 QTLs associados a PG em milho. Em todos os cromossomos foram localizadas regiões associadas a QTLs a este caráter, como ocorreu neste trabalho. Para PROL, somente no cromossomo 10 não foram detectados marcadores associados a este caráter, sendo que estes se concentraram nos cromossomos 1, 3 e 6. O caráter DE esteve associado a 41 marcadores distribuídos entre todos os cromossomos, estando presente em maior número nos cromossomos 1,7 e 8 . O caráter CE esteve associado a 43 marcadores distribuídos na maioria dos cromossomos, especialmente nos cromossomos 1,5 e 6, não sendo detectado apenas no cromossomo 7. Os marcadores associados ao peso de grãos, englobam os caracteres peso de grãos, peso de 300 grãos e peso de 1000 grãos. Ao todo 
foram identificados 119 marcadores, concentrados principalmente nos cromossomos 3 e 5. Foram encontrados 19 QTLs associados a NFI, os quais estão bem distribuídos pelos cromossomos, embora não tenha sido detectado nenhum marcador no cromossomo 8 . Para caracteres relacionados ao pendão, foram associados seis QTLs, estando localizados nos cromossomos 1, 2, 3 e 4 (Mickelson et al., 2002). Porém a grande maioria destes trabalhos foi realizada com germoplasma de origem temperada. Estes resultados juntamente com os obtidos nesta pesquisa, mostram que os genes responsáveis pelo controle genético destes caracteres estão distribuídos em todos os cromossomos do milho, e que a magnitude dos efeitos aditivos, dominantes e epistáticos foram variáveis. 


\section{CONCLUSÕES}

Os resultados obtidos no presente trabalho permitiram concluir que:

1. As magnitudes dos componentes da variância genética, do grau médio de dominância, e das correlações genéticas entre caracteres, para produção de grãos e seus componentes, mostraram que estes não diferiram em média daqueles obtidos com germoplasma temperado.

2. Os QTLs detectados para todos caracteres encontram-se distribuídos pelo genoma, e os efeitos aditivos, dominantes e epistáticos apresentaram magnitudes variáveis, como também relatado para milho temperado.

3. O somatório em módulo dos coeficientes significativos, mostrou que para os caracteres PG, PROL, CE e NGF os efeitos de dominância foram predominantes no controle genéticos destes caracteres, enquanto para os caracteres DE, P500, NFI e RP os efeitos aditivos foram predominantes.

4. O somatório dos efeitos epistáticos $\left(\hat{\beta_{2}}\right.$ e $\left.\hat{\beta}_{4}\right)$ mostraram-se importantes para todos caracteres analisados.

5. Os efeitos aditivos $\left(\hat{\beta}_{1}\right)$ foram bidirecionais para todos caracteres, enquanto os efeitos de dominância $\left(\hat{\beta}_{3}\right)$ mostraram-se unidirecionais para todos caracteres, exceto NFI. 
6. Detectou-se pequeno número de marcadores associados a QTLs que interagiram com ambientes.

7. As duas metodologias apresentaram resultados concordantes com relação aos efeitos aditivos e dominantes envolvidos no controle genético dos caracteres analisados. Porém, a análise do delineamento III associada a marcadores permitiu detectar que os efeitos epistáticos devem ser importantes no controle genético destes mesmos caracteres, além de permitir identificar regiões cromossômicas associadas a QTLs. 
ANEXOS 

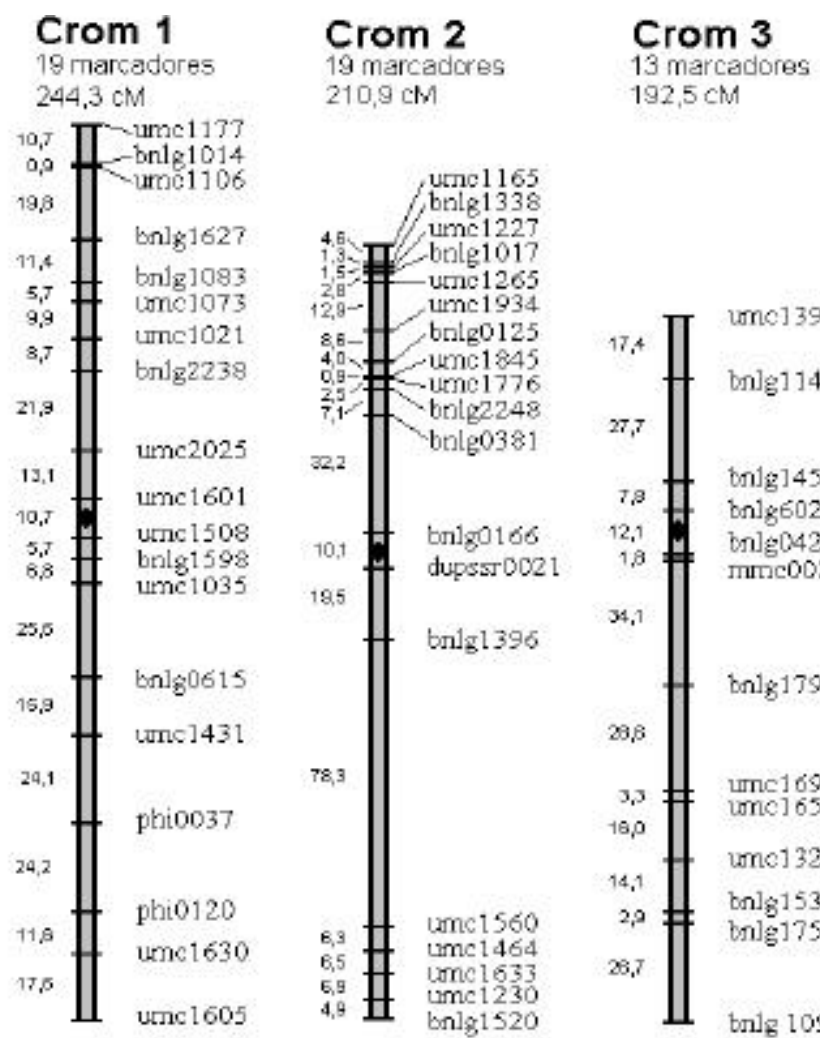

Crom 4

19 marcadores

$177,4 \mathrm{~cm}$

Crom 5

16 marcadores

$199.5 \mathrm{~cm}$

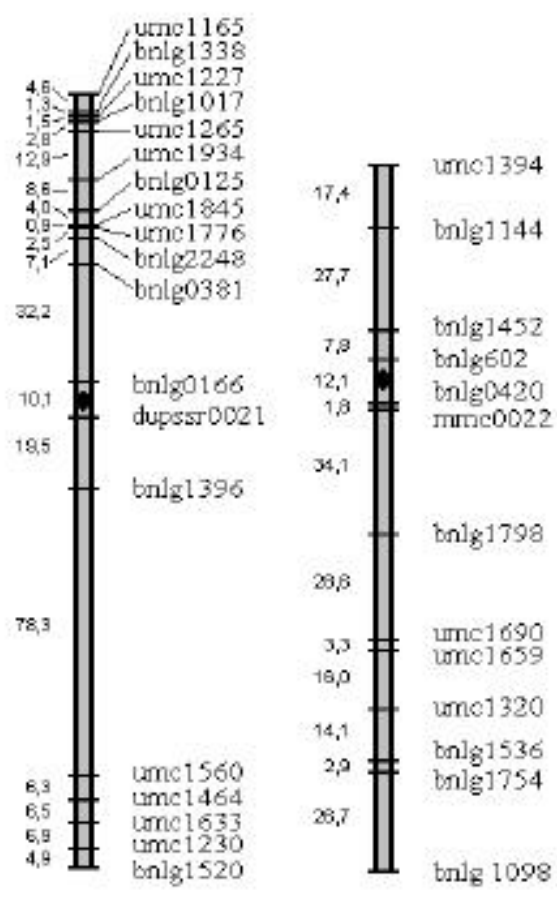

\section{Crom 7}

9 marcadores

$152,7 \mathrm{~cm}$

$162.9 \mathrm{~cm}$
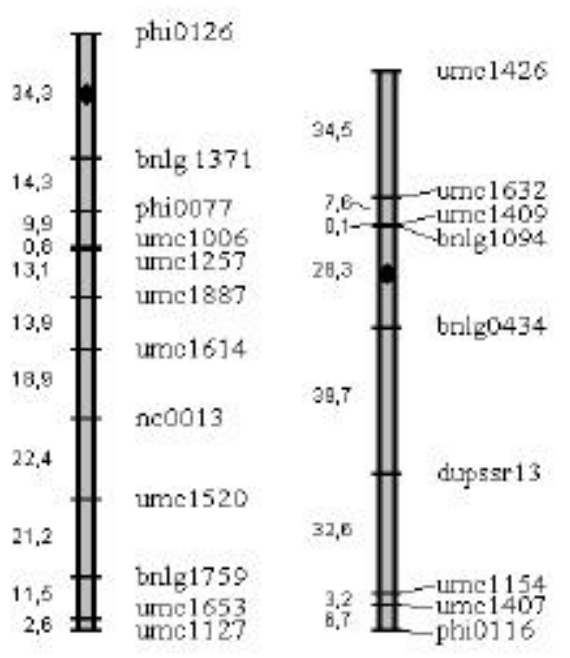

\section{Crom 8}

11 marcadores

$171.4 \mathrm{~cm}$

12,1 7 uncl139

${ }_{14,5}^{12,1}$ If phi420701

11.9 phiolis

11,9 f ume1034

22,0 \#nlg 1863

24,4

37,4 bolgl176

12,5
12,9
15,8

bolgl 607

bulg1 123

unc 1005

dupssr 14

bolgl 131
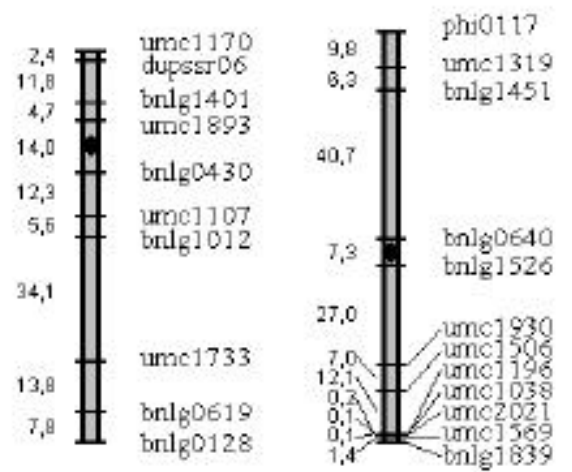

Crom 10

12 marcedores $112.0 \mathrm{~cm}$

Figura 1 - Mapa genético com 140 marcadores microssatélites distribuídos nos 10 cromossomos do milho, constituído de 1730,1 centiMorgam (cM) de extensão e 12,4 cM de intervalo médio entre marcadores adjacentes.

Fonte: Silva (2002)

Nota: Os números à esquerda do cromossomo são as distâncias em cM entre os marcadores; à direita está representado o nome do marcador. 


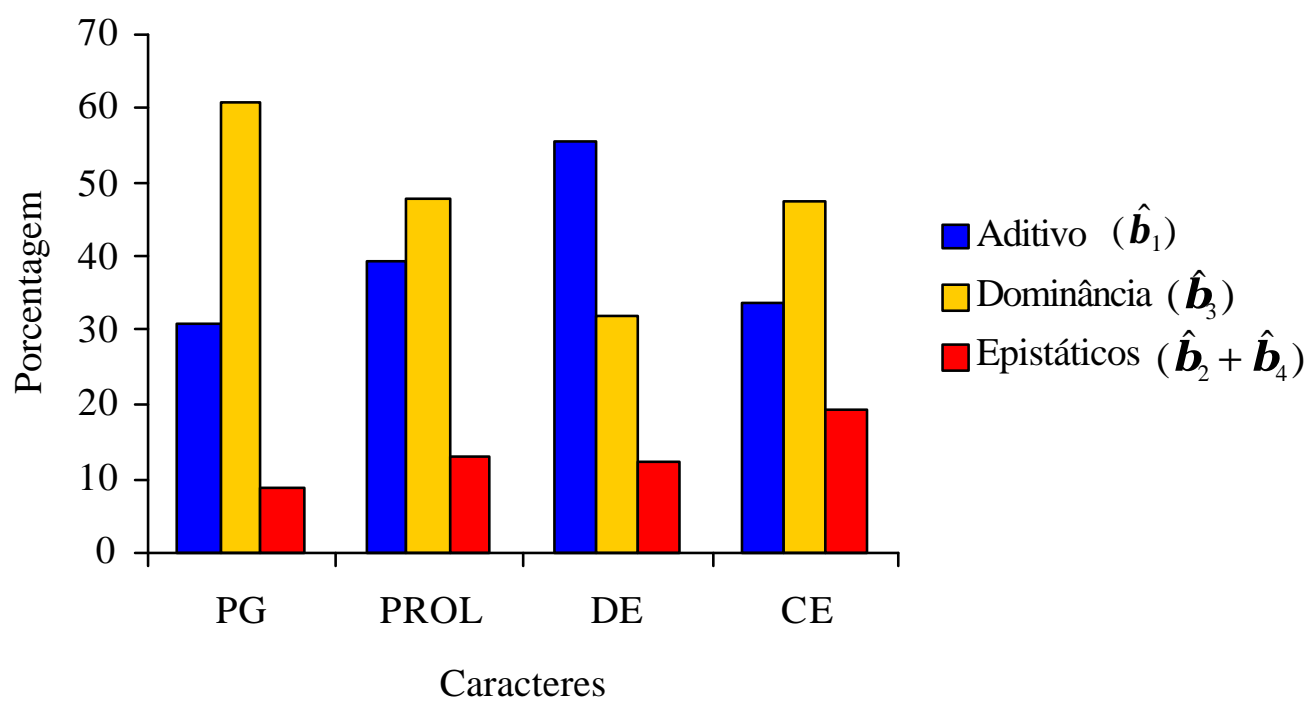

Figura 2 - Distribuição do somatório, em módulo, dos efeitos genéticos (aditivos, genéticos e epistáticos) para os caracteres de PG, PROL, DE e CE.

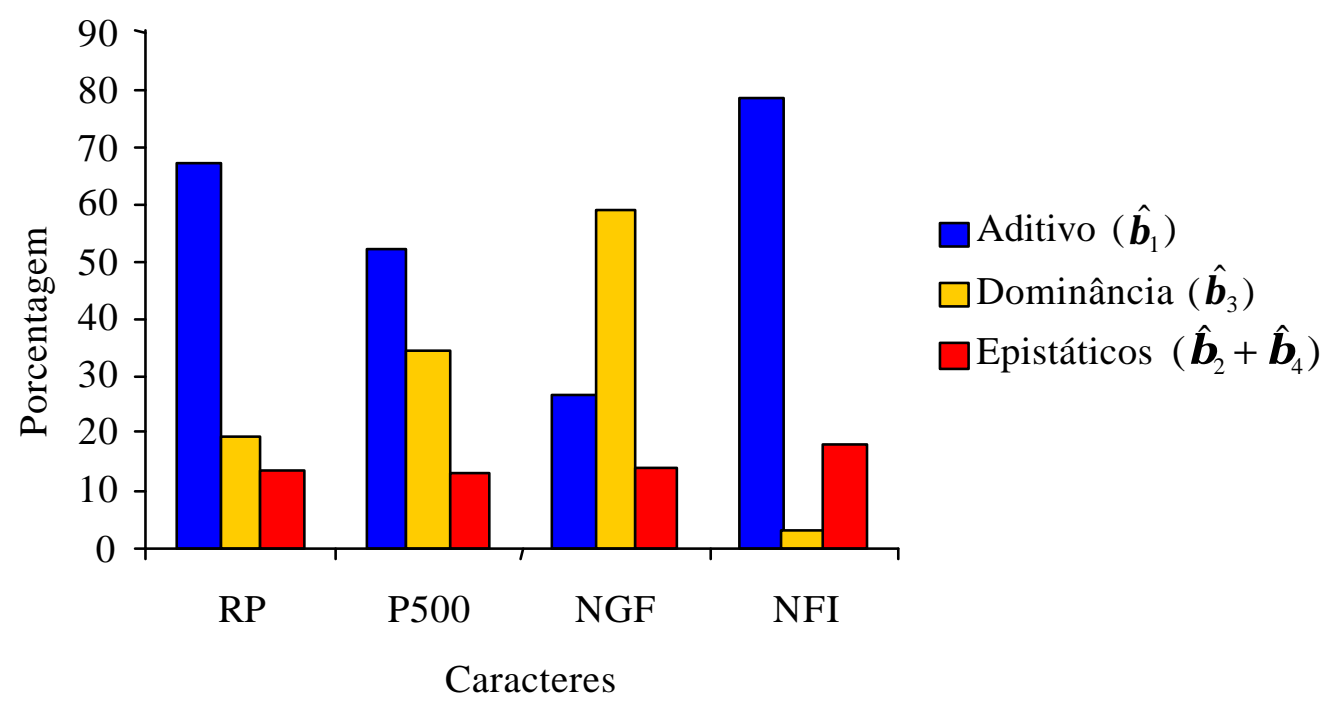

Figura 3 - Distribuição do somatório, em módulo, dos efeitos genéticos (aditivos, genéticos e epistáticos) para os caracteres RP, P500, NGF e NFI. 
Tabela 5.Resumo das análises de variâncias conjuntas agrupadas para os componentes de produção, médias das progênies retrocruzadas com as linhagens genitoras L-08-05F e L-14-04B e suas amplitudes.

\begin{tabular}{|c|c|c|c|c|c|c|c|c|c|}
\hline \multirow[b]{2}{*}{ Fonte variação } & \multirow[b]{2}{*}{$\mathrm{GL}^{\mathrm{b}}$} & \multicolumn{8}{|c|}{ QM } \\
\hline & & $\begin{array}{c}\text { PG } \\
\text { g planta }^{-1}\end{array}$ & $\begin{array}{c}\text { PROL }^{\mathrm{a}} \\
\text { esp.planta } \\
\end{array}$ & $\begin{array}{c}\mathrm{DE}^{\mathrm{a}} \\
\mathrm{cm} \mathrm{planta}^{-1} \\
\end{array}$ & $\begin{array}{c}\text { CE } \\
\mathrm{cm} \mathrm{planta}^{-1} \\
\end{array}$ & $\begin{array}{c}\text { NGF } \\
\text { grãos fileira }^{-1}\end{array}$ & $\begin{array}{c}\text { NFI } \\
\text { fileiras esp. }^{-1}\end{array}$ & $\begin{array}{c}\text { P500 } \\
\text { gramas }\end{array}$ & $\begin{array}{c}\mathrm{RP} \\
\text { ram pend. } .^{-1}\end{array}$ \\
\hline Progênie (Exp.) & 245 & $1199,07^{* *}$ & $64,87^{* *}$ & $143,66^{* *}$ & $2,86^{* *}$ & $16,95^{* *}$ & $4,08^{* *}$ & $623,08^{* *}$ & $28,51^{* *}$ \\
\hline Prog.x Genitor (Exp.) & 245 & $2194,69^{* *}$ & $49,91^{* *}$ & $66,92^{* *}$ & $2,22^{* *}$ & $17,55^{* *}$ & $0,95^{* *}$ & $302,44^{* *}$ & $9,09^{* *}$ \\
\hline Prog.x Ambiente (Exp.) & 1225 & $355,88^{* *}$ & $21,97^{*}$ & $22,27^{* *}$ & $0,52^{*}$ & $4,76^{* *}$ & $0,45^{* *}$ & $124,13^{* *}$ & $3,50^{* *}$ \\
\hline Prog.x Lin.x Amb.(Exp) & 1225 & $338,79^{* *}$ & $21,99^{*}$ & $22,62^{* *}$ & $0,54^{* *}$ & $4,35^{* *}$ & $0,43^{*}$ & $100,41^{\mathrm{ns}}$ & $2,88^{\mathrm{ns}}$ \\
\hline Resíduo & 2430 & 274,33 & 20,03 & 19,30 & 0,48 & 3,86 & 0,38 & 92,88 & 2,82 \\
\hline $\mathrm{CV}(\%)$ & & 14,24 & 12,97 & 3,31 & 4,30 & 5,63 & 5,18 & 6,18 & 10,18 \\
\hline Média Geral & & 116,35 & 1,09 & 4,19 & 16,09 & 34,90 & 11,90 & 155,93 & 16,50 \\
\hline Média RC L-14-04B & & 126,03 & 1,22 & 4,06 & 15,96 & 34,57 & 10,43 & 167,81 & 15,26 \\
\hline Média RC L-08-05F & & 106,67 & 0,96 & 4,33 & 16,21 & 35,24 & 13,37 & 144,06 & 17,75 \\
\hline $\mathrm{DMS}_{0,05}$ & & 5,96 & 0,05 & 0,05 & 0,24 & 0,68 & 0,21 & 10,81 & 1,88 \\
\hline Mínimo & & 70,41 & 0,71 & 3,74 & 14,40 & 30,35 & 8,83 & 120,89 & 11,78 \\
\hline Máximo & & 155,57 & 1,38 & 4,71 & 18,23 & 38,99 & 14,78 & 184,88 & 21,94 \\
\hline
\end{tabular}

a QM multiplicados por $10^{-3} ;^{*},{ }^{* *}$, significativo a 0,05 e 0,01 de probabilidade pelo teste de F, respectivamente; PG: produção de grãos; PROL: Prolificidade; DE: Diâmetro da espiga; CE: Comprimento da espiga; NFI: Número de fileira de grãos por espiga; NGF: Número de grãos por fileiras por espiga; P500: Peso de 500 grãos; RP: número de ramificações do pendão. DMS: Diferença mínima significativa. ${ }^{\mathrm{b}}$ Para o caráter P500 os GL para as fontes de variação que interagem com ambientes são diferentes do apresentado, já que este caráter foi avaliado em cinco ambientes. 
Tabela 6. Estimativas de parâmetros genéticos e seus respectivos intervalos de confiança a 0,95 de probabilidade, para produção de grãos. seus componentes e número de ramificações do pendão.

\begin{tabular}{|c|c|c|c|c|c|c|c|c|}
\hline \multirow[b]{2}{*}{ Caracteres } & \multicolumn{8}{|c|}{ Parâmetros genéticos } \\
\hline & $\hat{\sigma}_{G}^{2}$ & $\hat{\boldsymbol{\sigma}}_{A}^{2}$ & $\hat{\sigma}_{D}^{2}$ & $\hat{\sigma}_{A E}^{2}$ & $\hat{\sigma}_{D E}^{2}$ & $\hat{\sigma} \frac{2}{F}$ & $\hat{h}_{\bar{X}}^{2}$ & $\hat{\bar{d}}$ \\
\hline $\begin{array}{c}\mathrm{PG} \\
\left(\mathrm{g} \mathrm{planta}^{-1}\right)\end{array}$ & $\begin{array}{c}295,19 \\
{[237,69 ; 377,96]}\end{array}$ & $\begin{array}{c}140,53 \\
{[110,74 ; 184,46]}\end{array}$ & $\begin{array}{c}154,66 \\
{[126,95 ; 193,50]}\end{array}$ & $\begin{array}{c}81,56 \\
{[57,50 ; 127,95]}\end{array}$ & $\begin{array}{c}32,23 \\
{[20,68 ; 56,41]}\end{array}$ & $\begin{array}{c}49,96 \\
{[42,17 ; 60,14]}\end{array}$ & $\begin{array}{c}0,70 \\
{[0,64 ; 0,75]}\end{array}$ & $\begin{array}{c}1,48 \\
{[1,25 ; 1,75]}\end{array}$ \\
\hline $\begin{array}{c}\mathrm{PROL}^{/ 1} \\
\left(\text { espigas planta }^{-1}\right)\end{array}$ & $\begin{array}{c}94,77 \\
{[73,27 ; 129,91]}\end{array}$ & $\begin{array}{c}71,49 \\
{[55,83 ; 96,39]}\end{array}$ & $\begin{array}{c}23,28 \\
{[17,44 ; 33,52]}\end{array}$ & $\begin{array}{c}19,47 \\
{[9,14 ; 106,68]}\end{array}$ & $\begin{array}{c}9,81 \\
{[4,67 ; 54,52]}\end{array}$ & $\begin{array}{c}27,03 \\
{[22,81 ; 32,53]}\end{array}$ & $\begin{array}{c}0,66 \\
{[0,57 ; 0,72]}\end{array}$ & $\begin{array}{c}0,81 \\
{[0,65 ; 1,00]}\end{array}$ \\
\hline $\begin{array}{c}\mathrm{CE}^{/ 2} \\
\left(\mathrm{~cm} \mathrm{planta}{ }^{-1}\right)\end{array}$ & $\begin{array}{c}52,96 \\
{[42,99 ; 67,17]}\end{array}$ & $\begin{array}{c}38,91 \\
{[31,73 ; 49,12]}\end{array}$ & $\begin{array}{c}14,04 \\
{[11,26 ; 18,05]}\end{array}$ & $\begin{array}{c}4,54 \\
{[2,04 ; 23,83]}\end{array}$ & $\begin{array}{c}3,02 \\
{[1,52 ; 8,72]}\end{array}$ & $\begin{array}{c}11,91 \\
{[10,05 ; 14,34]}\end{array}$ & $\begin{array}{c}0,82 \\
{[0,78 ; 0,85]}\end{array}$ & $\begin{array}{c}0,85 \\
{[0,72 ; 1,00]}\end{array}$ \\
\hline $\begin{array}{c}\mathrm{DE}^{/ 3} \\
\left(\mathrm{~cm} \mathrm{planta}{ }^{-1}\right)\end{array}$ & $\begin{array}{c}23,92 \\
{[19,47 ; 30,26]}\end{array}$ & $\begin{array}{c}20,23 \\
{[16,58 ; 25,27]}\end{array}$ & $\begin{array}{c}3,69 \\
{[2,89 ; 4,99]}\end{array}$ & $\begin{array}{c}2,97 \\
{[1,70 ; 7,48]}\end{array}$ & $\begin{array}{c}1,66 \\
{[0,98 ; 3,60]}\end{array}$ & $\begin{array}{c}5,99 \\
{[5,05 ; 7,21]}\end{array}$ & $\begin{array}{c}0,84 \\
{[0,81 ; 0,87]}\end{array}$ & $\begin{array}{c}0,60 \\
{[0,51 ; 0,72]}\end{array}$ \\
\hline $\mathrm{NFI}^{/ 2}$ & $\begin{array}{c}64,81 \\
{[53,25 ; 80,88]}\end{array}$ & $\begin{array}{c}60,41 \\
{[49,98 ; 74,57]}\end{array}$ & $\begin{array}{c}4,40 \\
{[3,27 ; 6,32]}\end{array}$ & $\begin{array}{c}7,33 \\
{[4,56 ; 14,84]}\end{array}$ & $\begin{array}{c}2,25 \\
{[1,15 ; 8,12]}\end{array}$ & $\begin{array}{c}16,99 \\
{[14,34 ; 20,45]}\end{array}$ & $\begin{array}{c}0,89 \\
{[0,86 ; 0,91]}\end{array}$ & $\begin{array}{c}0,38 \\
{[0,32 ; 0,47]}\end{array}$ \\
\hline $\mathrm{NGF}^{/ 4}$ & $\begin{array}{c}31,32 \\
{[25,03 ; 40,94]}\end{array}$ & $\begin{array}{c}20,32 \\
{[16,18 ; 26,68]}\end{array}$ & $\begin{array}{c}11,00 \\
{[8,85 ; 14,26]}\end{array}$ & $\begin{array}{c}8,99 \\
{[5,67 ; 16,14]}\end{array}$ & $\begin{array}{c}2,48 \\
{[1,28 ; 7,37]}\end{array}$ & $\begin{array}{c}7,06 \\
{[5,96 ; 8,50]}\end{array}$ & $\begin{array}{c}0,72 \\
{[0,66 ; 0,77]}\end{array}$ & $\begin{array}{c}1,04 \\
{[0,87 ; 1,24]}\end{array}$ \\
\hline $\begin{array}{c}\text { P500 } \\
\text { (gramas) }\end{array}$ & $\begin{array}{c}120,50 \\
{[97,47 ; 154,41]}\end{array}$ & $\begin{array}{c}99,79 \\
{[81,12 ; 126,80]}\end{array}$ & $\begin{array}{c}20,71 \\
{[16,35 ; 27,62]}\end{array}$ & $\begin{array}{c}28,80 \\
{[19,84 ; 46,20]}\end{array}$ & $\mathrm{ns}$ & $\begin{array}{c}31,15 \\
{[26,30 ; 37,50]}\end{array}$ & $\begin{array}{c}0,80 \\
{[0,76 ; 0,84]}\end{array}$ & $\begin{array}{c}0,64 \\
{[0,54 ; 0,76]}\end{array}$ \\
\hline $\begin{array}{c}\mathrm{RP}^{/ 4} \\
\left(\text { ram. planta }{ }^{-1}\right)\end{array}$ & $\begin{array}{c}46,88 \\
{[38,66 ; 58,80]}\end{array}$ & $\begin{array}{c}41,68 \\
{[34,55 ; 51,87]}\end{array}$ & $\begin{array}{c}5,20 \\
{[4,11 ; 6,93]}\end{array}$ & $\begin{array}{c}6,58 \\
{[4,39 ; 11,34]}\end{array}$ & $\mathrm{ns}$ & $\begin{array}{c}11,88 \\
{[10,02 ; 14,30]}\end{array}$ & $\begin{array}{c}0,88 \\
{[0,85 ; 0,90]}\end{array}$ & $\begin{array}{c}0,50 \\
{[0,42 ; 0,59]}\end{array}$ \\
\hline
\end{tabular}

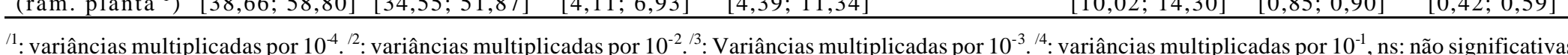
pelo teste de $F . \hat{\sigma}_{G}^{2}$ : estimativa da variância genética, $\hat{\sigma}_{A}^{2}$ : estimativa da variância aditiva, $\hat{\sigma}_{D}^{2}$ : estimativa da variância de dominância, $\hat{\sigma}_{A E}^{2}$ :estimativada variânciada interação aditiva com ambientes, $\hat{\sigma}_{D E}^{2}$ : estimativa da variância da interação de dominância com ambientes, $\hat{\sigma} \frac{2}{F}$ : estimativa da variância fenotípica entre média de progênies, $\hat{h}_{\bar{X}}^{2}$ : estimativa da herdabilidade média entre progênies de meios-irmãos, $\hat{\bar{d}}$ : estimativa do grau médio de dominância. PG: produção de grãos; PROL: prolificidade; CE: comprimento da espiga; DE: diâmetro da espiga; NFI: número de fileiras; NGF: número de grãos por fileira; P500: peso de 500 grãos; RP: número de ramificações do pendão. 
Tabela 7.Estimativas das correlações aditivas ( $\hat{r}_{a}$, acima da diagonal), genéticas ( $\hat{r}_{g}$, abaixo da diagonal) e fenotípicas ( $\hat{r}_{\bar{F}}$, entre parênteses), entre os caracteres analisados.

\begin{tabular}{ccccccccc}
\hline Caráter & PG & PROL & DE & CE & NGF & NFI & RP & P500 \\
\hline PG & & 0,51 & 0,52 & 0,12 & 0,52 & 0,13 & 0,08 & 0,11 \\
PROL & $0,56\left(0,46^{* *}\right)$ & & $-0,14$ & $-0,15$ & $-0,03$ & $-0,20$ & $-0,25$ & $-0,17$ \\
DE & $0,57\left(0,48^{* *}\right)$ & $-0,02\left(-0,07^{\text {ns }}\right)$ & & $-0,20$ & 0,05 & 0,63 & 0,26 & 0,14 \\
CE & $0,39\left(0,16^{*}\right)$ & $0,00\left(-0,08^{\text {ns }}\right)$ & $-0,03\left(-0,12^{\text {ns }}\right)$ & & 0,46 & $-0,19$ & 0,07 & 0,25 \\
NGF & $0,66\left(0,42^{* *}\right)$ & $-0,03\left(-0,03^{\text {ns }}\right)$ & $0,21\left(0,09^{\text {ns }}\right)$ & $0,61\left(0,50^{* *}\right)$ & & $-0,07$ & 0,12 & $-0,20$ \\
NFI & $0,12\left(0,12^{\text {ns }}\right)$ & $-0,16\left(-0,13^{*}\right)$ & $0,61\left(0,61^{* *}\right)$ & $-0,15\left(-0,17^{* *}\right)$ & $-0,03\left(-0,06^{\text {ns }}\right)$ & & 0,34 & $-0,46$ \\
RP & $0,20\left(0,09^{\text {ns }}\right)$ & $-0,15\left(-0,15^{*}\right)$ & $0,29\left(0,23^{* *}\right)$ & $0,16\left(0,07^{\text {ns }}\right)$ & $0,21\left(0,11^{\text {ns }}\right)$ & $0,32\left(0,31^{* *}\right)$ & & $-0,08$ \\
P500 & $0,31\left(0,16^{*}\right)$ & $0,02\left(-0,12^{\text {ns }}\right)$ & $0,23\left(0,16^{*}\right)$ & $0,33\left(0,24^{* *}\right)$ & $-0,01\left(-0,16^{*}\right)$ & $-0,41\left(-0,41^{* *}\right)$ & $-0,01\left(-0,06^{\text {ns }}\right)$ & \\
\hline
\end{tabular}

${ }^{*},{ }^{* *}$ significativo, pelo teste de $t$, a 0,01 e 0,05 de probabilidade, respectivamente. ${ }^{\text {ns }}$ não significativo. PG: produção de grãos; PROL: prolificidade; DE: diâmetro da espiga; CE: comprimento da espiga; NGF: número de grãos por espiga; NFI: número de fileiras de grãos; P500: peso de 500 grãos; RP: número de ramificações do pendão. 
Tabela 8. Estimativas e significâncias dos coeficientes de regressão parciais (ấs) para os caracteres produção de grãos (PG) e prolificidade (PROL).

\begin{tabular}{|c|c|c|c|c|c|c|c|c|c|c|c|}
\hline \multirow{2}{*}{$C^{a}$} & \multirow{2}{*}{ Bin } & \multirow{2}{*}{$\mathrm{cM}^{\mathrm{b}}$} & \multirow{2}{*}{ Marcador } & \multicolumn{4}{|c|}{ PG (g. planta $\left.{ }^{-1}\right)$} & \multicolumn{4}{|c|}{ PROL $^{\mathrm{d}}\left(\right.$ esp. planta $\left.^{-1}\right)$} \\
\hline & & & & $\hat{a}_{1}^{c}$ & $\hat{a}_{2}$ & $\hat{a}_{3}$ & $\hat{a}_{4}$ & $\hat{a}_{1}$ & $\hat{a}_{2}$ & $\hat{a}_{3}$ & $\hat{a}_{4}$ \\
\hline \multirow[t]{19}{*}{1} & 1.01 & 10,7 & umclTTt & 0,15 & $-0,20$ & $2,26^{* *}$ & $0,66^{*}$ & $-1,47$ & $-0,09$ & $9,12 *$ & 1,84 \\
\hline & 1.01 & 0,9 & bnlg1014 & 0,67 & 0,08 & $2,03 * *$ & 0,07 & $-2,91$ & 0,27 & $8,93^{* *}$ & 0,62 \\
\hline & 1.00 & 19,8 & umc1106 & $0,75 *$ & 0,14 & $2,40 * * *$ & 0,00 & $-0,89$ & 1,44 & $10,05 * * *$ & 0,13 \\
\hline & 1.02 & 11,4 & bnlg 1627 & $-0,39$ & 0,31 & $2,00 * *$ & $-0,16$ & $-0,70$ & $-3,31$ & 4,87 & $-0,84$ \\
\hline & 1.02 & 5,7 & bnlg1083 & $-0,47$ & $-0,19$ & $2,21 * * *$ & 0,06 & $-5,17$ & $-3,55$ & $7,15^{*}$ & 1,80 \\
\hline & 1.03 & 9,9 & umc 1073 & $-0,94$ & $-0,47 *$ & $2,85 * * *$ & $0,32 * *$ & $-9,69 *$ & $-3,25 *$ & $9,63^{*}$ & 1,66 \\
\hline & 1.03 & 8,7 & umc1021 & $-2,00 *$ & $-0,34$ & $4,24 * * *$ & 0,35 & $-14,26 *$ & $-2,16$ & $21,69 * *$ & 3,34 \\
\hline & 1.04 & 21,9 & bnlg2238 & $-1,58 * *$ & 0,04 & $3,22 * * *$ & $-0,05$ & $-15,73 *$ & 1,60 & $14,56 * *$ & 0,58 \\
\hline & 1.05 & 13,1 & umc 2025 & $-2,03 *$ & $0,54 * *$ & $4,19 * * * *$ & $-0,43 *$ & $-15,09 *$ & 3,18 & $19,45 * * *$ & 0,65 \\
\hline & 1.05 & 10,7 & umc1601 & $-1,64 *$ & $-0,13$ & $3,50 * * * *$ & $-0,11$ & $-10,03$ & $-1,56$ & 20,53 **** & $2,39 *$ \\
\hline & 1.06 & 5,7 & umc 1508 & $-2,13 *$ & $-0,41$ & $2,55 * *$ & 0,13 & $-11,82$ & $-4,56$ & $16,50 * * *$ & $4,31 *$ \\
\hline & 1.06 & 6,8 & bnlg 1598 & $-2,69 * *$ & $-0,72 * *$ & $2,43 * *$ & 0,22 & $-15,44 * *$ & $-6,18 *$ & $18,44 * *$ & $4,31 *$ \\
\hline & 1.06 & 25,6 & umc1035 & $-2,27 * *$ & $-0,55$ & $3,05 * * *$ & $0,58 *$ & $-9,49$ & $-4,15$ & $19,86 * *$ & $5,64 *$ \\
\hline & 1.07 & 15,9 & bnlg0615 & $-0,47$ & $-0,24$ & $2,23 * *$ & 0,20 & $-9,01$ o & $-1,32_{\text {oо }}$ & $14,20 * *$ & 3,44 \\
\hline & 1.10 & 24,1 & umc1431 & $-1,21 *$ & 0,13 & $1,29 *$ & 0,09 & $-3,84$ & $-1,63$ & 6,67 & 1,60 \\
\hline & 1.08 & 24,2 & phi0037 & $-0,15$ & $-0,09$ & $2,83 * *$ & $0,67 * *$ & $-2,60$ & $-3,41$ & $13,01 *$ & 2,08 \\
\hline & 1.11 & 11,6 & phi0120 & $-0,51 *$ & $0,62 * *$ & $1,15^{*}$ & $-0,68 * *$ & $-1,16$ & 0,19 & 3,18 & $-1,44$ \\
\hline & 1.11 & 17,6 & umc 1630 & $-0,16$ & 0,19 & 0,77 & 0,07 & 3,81 & $-1,44$ & 5,15 & 2,40 \\
\hline & 1.12 & & umc1605 & $1,16 * *$ & $-0,20$ & 0,37 & 0,24 & 4,19 & $-2,51 *$ & 3,23 & 1,85 \\
\hline \multirow[t]{19}{*}{2} & 2.01 & 4,6 & umc1165 & $-0,54$ & 0,14 & $1,39 * * *$ & $-0,16$ & $-7,41$ & $-0,11$ & $6,95 *$ & $-3,05$ \\
\hline & 2.01 & 1,3 & bnlg1338 & $-0,67$ & $-0,02$ & $2,43 * * * *$ & $-0,18$ & $-8,58$ & $-0,11$ & $9,04 * *$ & $-3,05$ \\
\hline & 2.01 & 1,5 & umc1227 & $-0,29$ & $-0,05$ & $1,55 * *$ & $-0,06$ & $-7,27$ & $-0,58$ & $6,05 *$ & $-2,51$ \\
\hline & 2.02 & 2,8 & bnlg1017 & $-0,42$ & $-0,16$ & $1,92 * * *$ & 0,02 & $-7,64$ & $-0,95$ & $8,70 *$ & $-1,92$ \\
\hline & 2.02 & 12,9 & umc 1265 & $-0,81 *$ & $-0,43$ & $2,04 * * *$ & $-0,05$ & $-13,01 *$ & $-0,96$ & 7,82 & $-0,94$ \\
\hline & 2.02 & 8,6 & umc1934 & $-0,69 *$ & $-0,37 *$ & $2,72 * *$ & 0,27 & $-11,79 * * *$ & $-2,69$ & $13,24 *$ & 0,79 \\
\hline & 2.02 & 4,0 & bnlg0125 & $-0,24$ & 0,00 & $2,24 * *$ & 0,26 & $-14,27 * *$ & 0,93 & 10,40 * & $-0,45$ \\
\hline & 2.03 & 0,9 & umc 1845 & $-1,05$ & 0,12 & $3,66 * * *$ & $-0,77 * *$ & $-19,38 * *$ & 2,63 & $13,52 *$ & $-3,77$ \\
\hline & 2.03 & 2,5 & umc 1776 & $-1,14$ & 0,38 & $3,39 * * *$ & $-0,48$ & $-20,56 * *$ & 2,70 & $12,11 * *$ & $-2,53$ \\
\hline & 2.03 & 7,1 & bnlg 2248 & $-1,38 *$ & $-0,04$ & $4,06 * * * * *$ & $-0,16$ & $-20,90 * * *$ & 2,67 & $15,63 *$ & $-2,13$ \\
\hline & 2.03 & 32,2 & bnlg0381 & $-0,76^{*}$ & 0,27 & $3,02 * * *$ & $-0,07$ & $-21,67 * *$ & $4,13 *$ & $13,86 *$ & $-2,82$ \\
\hline & 2.04 & 10,1 & bnlg0166 & $-1,75 * *$ & 0,06 & $2,25 * *$ & $-0,27$ & $-13,07 * *$ & $-0,10$ & $11,08 * *$ & $-3,37$ \\
\hline & 2.05 & 19,5 & dupssr21 & $-1,85 * * *$ & $-0,46$ & $1,96 * *$ & $0,56 *$ & $-10,28 *$ & $-5,06 * * * *$ & 8,16 & 0,09 \\
\hline & 2.06 & 78,3 & bnlg 1396 & $-0,30$ & $-0,21$ & 1,11 & 0,21 & 3,67 & $-1,44$ & 3,81 & $-0,73$ \\
\hline & 2.07 & 6,3 & umc 1560 & $-0,86$ & $-0,15$ & 0,78 & $-0,59 *$ & $-2,46$ & $-0,88$ & 1,86 & $-1,23$ \\
\hline & 2.08 & 6,5 & umc1464 & $-0,95$ & $-0,15$ & $1,51 * *$ & 0,24 & $-2,06$ & $-0,68$ & 2,34 & 2,36 \\
\hline & 2.08 & 6,9 & umc 1633 & $-0,92$ & 0,02 & $0,88^{*}$ & 0,28 & $-1,48$ & 1,44 & 0,39 & 2,35 \\
\hline & 2.09 & 4,9 & umc 1230 & $-1,28$ & $-0,04$ & $0,74 *$ & 0,50 & 1,24 & 2,21 & 1,39 & $3,44 * *$ \\
\hline & 2.09 & & bnlg 1520 & $-1,01$ & 0,04 & 0,51 & 0,19 & 3,49 & 2,65 & 1,19 & 1,17 \\
\hline \multirow[t]{13}{*}{3} & 3.01 & 17,4 & umc1394 & $-0,20$ & $-0,34$ & 0,04 & $-0,19$ & 0,52 & $-2,21$ & 3,11 & $-0,78$ \\
\hline & 3.03 & 27,7 & bnlg 1144 & $-0,76^{*}$ & 0,32 & $1,89 * *$ & 0,08 & $-7,94 *$ & 2,50 & 4,58 & 0,21 \\
\hline & 3.04 & 7,8 & bnlg 1452 & $-0,03$ & 0,47 & $2,15 * *$ & $-0,56 *$ & $-3,98$ & 1,79 & 1,55 & $-3,20 * *$ \\
\hline & 3.04 & 12,1 & bnlg602 & $-0,47$ & 0,21 & $2,28 * *$ & $-0,17$ & $-7,86$ & $-1,51$ & $-1,35$ & $-2,08$ \\
\hline & 3.05 & 1,8 & bnlg0420 & $-0,76$ & 0,12 & $1,07 * *$ & $-0,11$ & $-5,62$ & 0,30 & $-2,83$ & 0,18 \\
\hline & 3.05 & 34,1 & $\mathrm{mmc} 0022$ & $-0,65$ & 0,09 & $1,49 * * * * *$ & $-0,02$ & $-6,33$ & 0,88 & $-1,93$ & 0,34 \\
\hline & 3.06 & 28,6 & bnlg1798 & $-2,13 * *$ & $-0,32$ & 0,89 & $0,84 * * *$ & $-10,50$ & $-2,20$ & $-1,72$ & $4,47 *$ \\
\hline & 3.07 & 3,3 & umc 1690 & $-0,87$ & 0,01 & 0,48 。 & $-0,64 *$ & $-6,27 *$ & 3,87 。 & $-0,05_{0}$ & $-2,02$ \\
\hline & 3.07 & 16,0 & umc 1659 & $-1,50$ & $-0,03$ & 0,27 & $-0,27$ & $-14,34 * *$ & 1,88 & 0,37 & 0,77 \\
\hline & 3.08 & 14,1 & umc 1320 & $-1,90 *$ & $-0,12$ & $1,75^{*}$ & 0,14 & $-21,62 * *$ & $-0,05$ & 8,03 & 1,76 \\
\hline & 3.09 & 2,9 & bnlg 1536 & $-1,78 *$ & $-0,27$ & 0,95 & 0,23 & $-22,40 *_{\mathrm{o}}$ & $-0,59$ & 4,81 & $3,81 *$ \\
\hline & 3.09 & 26,7 & bnlg 1754 & $-1,66 *$ & $-0,17$ & 0,76 & $-0,11$ & $-21,32 * *$ & 1,83 & 1,68 & $2,60 *$ \\
\hline & 3.10 & & bnlg1098 & $-1,38 *$ & $-0,68 * * *$ & 0,28 & $-0,08$ & $-11,46 *$ & $-1,10$ & 7,18 & $3,90 * *$ \\
\hline
\end{tabular}


Tabela 8. Estimativas e significâncias dos coeficientes de regressão parciais (ấs) para os caracteres produção de grãos (PG) e prolificidade (PROL).

\begin{tabular}{|c|c|c|c|c|c|c|c|c|c|c|c|}
\hline \multirow{2}{*}{$\mathrm{C}^{\mathrm{a}}$} & \multirow{2}{*}{ Bin } & \multirow{2}{*}{$\mathrm{cM}^{\mathrm{b}}$} & \multirow{2}{*}{ Marcador } & \multicolumn{4}{|c|}{ PG (g. planta $\left.{ }^{-1}\right)$} & \multicolumn{4}{|c|}{ PROL $^{\mathrm{d}}\left(\right.$ esp. planta $\left.^{-1}\right)$} \\
\hline & & & & $\hat{a}_{1}^{c}$ & $\hat{a}_{2}$ & $\hat{a}_{3}$ & $\hat{a}_{4}$ & $\hat{a}_{1}$ & $\hat{a}_{2}$ & $\hat{a}_{3}$ & $\hat{a}_{4}$ \\
\hline \multirow[t]{19}{*}{4} & 4.01 & 55,7 & umc 1276 & $0,42_{\text {oo }}$ & $-0,390$ & $2,13^{*}$ & $0,27 * *$ & $-0,22$ & $-3,61^{*}$ & 5,15 & $-0,26$ \\
\hline & 4.04 & 3,4 & umc 1652 & $-0,16$ & 0,09 & $1,25^{*}$ & 0,15 & 1,32 & $-3,68 *$ & $6,70 *$ & 1,20 \\
\hline & 4.05 & 0,1 & phi0026 & 0,06 & 0,23 & $0,92 *$ & $-0,27$ & 2,72 & $-2,15$ & $4,90 *$ & $-0,53$ \\
\hline & 4.05 & 1,7 & umc 1088 & $-0,10$ & 0,07 & $1,36 * *$ & 0,02 & 0,69 & $-3,27 * *$ & $7,67 *$ & 0,40 \\
\hline & 4.06 & 35,6 & bnlg0252 & $-0,09$ & 0,20 & $1,08 * *$ & $-0,05$ & 1,25 & $-1,55$ & $4,98 *$ & 0,29 \\
\hline & 4.07 & 5,1 & bnlg2291 & 0,42 & 0,28 & $1,37 * * *$ & $-0,27$ & $7,39 *$ & $3,92 * *$ & $8,48^{* *}$ & 1,57 \\
\hline & 4.07 & 18,0 & dupssr34 & 0,17 & 0,29 & $0,74 * *$ & $-0,38$ & $6,06^{*}$ & $4,44 *$ & $6,85 * *$ & 0,02 \\
\hline & 4.08 & 2,0 & bnlg 2244 & 0,63 & 0,40 & $1,50^{*}$ & $-0,88^{*}$ & 9,07 & $5,28 * *$ & 8,21 & $-2,94$ \\
\hline & 4.08 & 4,7 & bnlg 2162 & 0,59 & 0,49 & 0,52 & $-1,19 * *$ & 11,54 & $6,79 * * *$ & 4,89 & $-3,82$ \\
\hline & 4.08 & 4,6 & umc1086 & 0,34 & 0,35 & $2,04 * *$ & $-0,11$ & 6,07 。 & $5,56 * * *$ & 9,18 & 0,38 \\
\hline & 4.08 & 11,5 & umc 1051 & 0,07 & $0,51 *$ & $1,43^{*}$ & $-0,02$ & 5,23 。 & $5,73 * * *$ & 6,93 & 1,18 \\
\hline & 4.09 & 15,6 & umc1989 & $-0,33$ & $-0,15$ & 0,12 & 0,14 & $1,00_{0}$ & 1,16 & 1,32 & 0,02 \\
\hline & 4.09 & 0,6 & phi314704 & $-0,86$ & $-0,40$ & $-0,75$ & $-0,40$ & $-3,74$ oо & $1,75_{\circ}$ & $-0,11$ & $-0,63$ \\
\hline & 4.11 & 0,2 & bnlg0589 & $-0,59$ & $-0,46^{*}$ & $-0,57$ & $-0,33$ & $-7,27$ oо & $-0,72_{o}$ & 0,39 & $-0,21$ \\
\hline & 4.10 & 0,2 & umc 1503 & $-1,03$ & $-0,61 *$ & $-0,41$ & $-0,23$ & $-5,27$ oо & 0,27 。 & 1,36 & 0,28 \\
\hline & 4.10 & 5,9 & umc1532 & $-0,90$ & $-0,55^{*}$ & $-0,39$ & $-0,14$ & $-5,46$ oо & $-0,11 \mathrm{o}$ & 2,16 & 0,94 \\
\hline & 4.10 & 6,3 & umc1109 & $-0,56$ & $-0,56^{*}$ & $-1,06$ & $-0,81 * *$ & $-1,05$ & 3,29 & $-1,45$ & $-1,95$ \\
\hline & 4.11 & 6,2 & bnlg 1337 & $-0,46$ & $-0,59$ & $-0,94$ & $-0,43$ & $-0,36$ & $-0,04$ & $-2,46$ & $-0,78$ \\
\hline & 4.11 & & umc1197 & $-0,24$ & $-0,27$ & $-0,57$ & $-0,64$ & $-1,07$ & 2,08 & 0,57 & $-0,50$ \\
\hline \multirow[t]{16}{*}{5} & 5.00 & 40,7 & bnlg1006 & $-1,21$ & 0,04 & $1,95^{* *}$ & $-0,31$ & $-11,15 *$ & $2,89 *$ & $12,99 * *$ & $-2,42$ \\
\hline & 5.02 & 8,3 & umc 1587 & $-0,14$ & $-0,30$ & $2,24 * *$ & $-0,19$ & $-5,00 *$ & $-0,71$ & $10,29 * *$ & $-2,36^{*}$ \\
\hline & 5.03-04 & 5,3 & phi0113 & $-0,07$ & $-0,25$ & $2,29 * * *$ & 0,11 & $-5,28$ & $-2,35$ & $10,15 * *$ & $-1,71$ \\
\hline & 5.03 & 16,1 & bnlg 1879 & $-0,64$ & $-0,58 *$ & $2,57 * * *$ & $-0,07$ & $-10,01 *$ & $-3,35 *$ & $12,34 * *$ & $-1,21$ \\
\hline & 5.03 & 14,1 & umc 1056 & 0,13 & 0,46 & $2,63 * *$ & $-0,54 * *$ & $-9,22$ & 1,15 & $8,23^{*}$ & $-3,06^{*}$ \\
\hline & 5.03 & 9,7 & bnlg1902 & 1,19 & 0,53 & $3,27 * *$ & $-0,72 * *$ & $-3,39$ 。 & 2,04 & $12,61 * *$ & 0,03 \\
\hline & 5.04 & 17,7 & dupssr10 & 0,89 & 0,58 & $4,10 * * *$ & $-0,87 * * *$ & $-4,04_{0}$ & 0,80 & $14,94 * *$ & $-1,19$ \\
\hline & 5.04 & 3,8 & umc1221 & $1,78 *$ & $-0,06$ & $3,11 * *$ & $-0,72 * *$ & 9,74 & $-0,50$ & $8,73^{*}$ & $-0,72$ \\
\hline & 5.05 & 23,5 & $\mathrm{mmc} 0081$ & 1,47 & 0,20 & $2,81 * *$ & $-1,04 * *$ & 8,07 & 0,72 & $6,78^{*}$ & $-3,13$ \\
\hline & 5.06 & 2,1 & umc1019 & $2,45 *$ & 0,22 & 0,76 & $-0,42 *$ & $16,43 * *$ & 1,65 & $-1,88$ & $-1,07$ \\
\hline & 5.06 & 2,3 & mmc0481 & $2,06^{*}$ & $-0,11$ & $1,41 *$ & $-0,17$ & $14,83 *$ & $-0,28$ & 0,41 & 0,06 \\
\hline & 5.05-06 & 51,6 & bnlg278 & $2,08 * 0$ & $-0,22$ & $0,97 *$ & $-0,03$ & $14,10 *$ & $-0,81$ & $-0,88$ & 1,04 \\
\hline & 5.06 & 0,1 & umc1680 & $2,25 *$ 。 & $-0,23$ & 1,08 & $-0,01$ & $14,85 *$ & $-1,14$ & 0,71 & 0,84 \\
\hline & 5.06 & 21,9 & umc1524 & $2,13 *_{0}$ & $-0,26$ & 1,26 & $-0,02$ & $14,50 *$ & $-1,29$ & 1,43 & 0,84 \\
\hline & 5.07 & 32,3 & phi0128 & $1,46_{\circ}$ & $-0,40$ & 0,97 & 0,08 & 7,60 & $-2,91$ & $-0,40$ & 0,41 \\
\hline & 5.09 & & umc1153 & $-0,33$ & 0,42 & $-0,40$ & $-0,25$ & $-1,19$ & 0,67 & 1,78 & 0,68 \\
\hline \multirow[t]{12}{*}{6} & 6.00 & 34,3 & phi0126 & $-0,72$ & $0,33^{*}$ & $0,99 *$ & $-0,92 * *$ & $-6,62$ & 2,97 & 2,82 & $-2,48$ \\
\hline & 6.02 & 14,3 & bnlg1371 & $-1,23 *$ & 0,20 & $1,52 * * *$ & $-0,39$ & $-5,84 *$ & 1,59 & $7,70 *$ & $-3,09 * *$ \\
\hline & 6.01 & 9,9 & phi0077 & $-1,21 *$ & 0,13 & $3,42 * * * * *$ & $-0,11$ & $-5,27$ & $-1,50$ & $14,85 * * *$ & $-2,09$ \\
\hline & 6.02 & 0,8 & umc1006 & $-0,73$ & 0,34 & $1,30 * *$ & $-0,44$ & $-3,58$ & $3,55^{*}$ & $9,06^{*}$ & $-3,07$ \\
\hline & 6.02 & 13,1 & umc1257 & $-0,38$ & 0,31 & $1,43 * *$ & $-0,49$ & $-0,25$ & $3,70 *$ & $7,83^{*}$ & $-3,42$ \\
\hline & 6.03 & 13,9 & umc1887 & $-0,53$ & 0,07 & $1,99 * * * *$ & 0,08 & $-4,31$ & 1,46 & 6,15 & 0,14 \\
\hline & 6.04 & 18,9 & umc1614 & $-0,80$ & $-0,17$ & $2,03 * * *$ & $-0,01$ & $-11,98$ & 1,19 & 5,98 & 0,84 \\
\hline & 6.05 & 22,4 & nc0013 & $-0,23$ & 0,14 & $1,04 *$ & $-0,25$ & $-3,36$ & 2,91 & 7,03 & $-0,34$ \\
\hline & 6.06 & 21,2 & umc 1520 & $-0,88$ & 0,24 & $0,76^{*}$ & $-0,02$ & $-8,37$ & 3,02 & 4,06 & $-0,51$ \\
\hline & 6.07 & 11,5 & bnlg 1759 & $-1,93 * *$ & 0,16 & 1,08 & $-0,41 *$ & $-13,38 *$ & $4,19 *$ & $10,36 *$ & $-1,96$ \\
\hline & 6.07 & 2,6 & umc 1653 & $-1,41 *$ & 0,03 & 0,71 & 0,23 & $-8,87$ & $4,69 * *$ & 3,98 & 1,17 \\
\hline & 6.08 & & umc 1127 & $-1,41 * *$ & $-0,13$ & 0,62 & 0,32 & $-8,15$ & $3,37 *$ & 5,19 & 1,71 \\
\hline
\end{tabular}


Tabela 8. Estimativas e significâncias dos coeficientes de regressão parciais (ấs) para os caracteres produção de grãos (PG) e prolificidade (PROL).

\begin{tabular}{|c|c|c|c|c|c|c|c|c|c|c|c|}
\hline \multirow{2}{*}{$\mathrm{C}^{\mathrm{a}}$} & \multirow{2}{*}{ Bin } & \multirow{2}{*}{$\mathrm{cM}^{\mathrm{b}}$} & \multirow{2}{*}{ Marcador } & \multicolumn{4}{|c|}{ PG (g. planta $\left.{ }^{-1}\right)$} & \multicolumn{4}{|c|}{ PROL $^{\mathrm{d}}\left(\right.$ esp. planta $\left.^{-1}\right)$} \\
\hline & & & & $\hat{a}_{1}{ }^{c}$ & $\hat{a}_{2}$ & $\hat{a}_{3}$ & $\hat{a}_{4}$ & $\hat{a}_{1}$ & $\hat{a}_{2}$ & $\hat{a}_{3}$ & $\hat{a}_{4}$ \\
\hline \multirow[t]{9}{*}{$T$} & 7.00 & 34,5 & umc1426 & $0,36_{0}$ & $-0,52^{*}$ & 0,33 & $0,38^{*}$ & 0,24 & $-1,82$ & 1,09 & $4,41 \%$ \\
\hline & 7.01 & 7,6 & umc1632 & $-2,89 * *$ & $-0,05$ & $3,18 * * *$ & $-0,05$ & $-22,00 * *$ & 1,94 & 7,25 & 1,47 \\
\hline & 7.01 & 0,1 & umc1409 & $-3,57 * *$ & $-0,01$ & $3,52 * * *$ & $-0,47$ & $-26,01 * *$ & 1,65 & 9,89 & $-1,14$ \\
\hline & 7.02 & 28,3 & bnlg1094 & $-3,16 * *$ & $-0,09$ & $3,57 * * *$ & $-0,46$ & $-24,62 * *$ & 1,48 & 10,01 & $-0,94$ \\
\hline & 7.03 & 39,7 & bnlg0434 & $-2,64 * *$ & 0,31 & $3,34 * * *$ & 0,19 & $-18,93 * *$ & $-0,01$ & $10,28 *$ & 0,46 \\
\hline & 7.04 & 32,6 & dupssr13 & $-2,01 * *$ & 0,02 & $1,28 * *$ & $-0,12$ & $-13,36 *$ & $-2,26_{0}$ & 2,00 & 0,73 \\
\hline & 7.05 & 3,2 & umc1154 & $-0,64$ & 0,62 & $-0,59$ & $-0,63 * *$ & $-9,62 *$ & 4,54 & $-4,25$ & $-0,15$ \\
\hline & 7.05 & 6,7 & umc1407 & $-1,25$ & $0,63 *$ & $-0,08$ & 0,06 & $-11,60 * *$ & 3,17 & $-1,01$ & $2,11 *$ \\
\hline & 7.06 & & phi0116 & $-0,87$ & $0,80 * * *$ & $-0,30$ & 0,25 & $-5,87$ & $5,35 *$ & $-1,50$ & $2,76^{* *}$ \\
\hline \multirow[t]{11}{*}{8} & 8.01 & 12,1 & umc1139 & $-0,12$ & $-0,22$ & $2,72 * * *$ & 0,35 & 1,74 & $-2,22$ & $11,82 * * *$ & $-0,36$ \\
\hline & 8.00 & 14,5 & phi420701 & 0,45 & $-0,08$ & $2,64 * *$ & 0,13 & 2,02 & $-0,14$ & $14,14 * *$ & $-2,02$ \\
\hline & 8.02 & 11,9 & phi0119 & $1,20_{\mathrm{o}}$ & 0,07 & $2,96 * *$ & 0,00 & $-2,43$ & 2,22 & $10,39 *$ & $-2,79$ \\
\hline & 8.03 & 22,0 & umc1034 & 0,64 o o & $-0,12$ & $2,59 *$ & $-0,32 * *$ & $-9,21_{0}$ & 1,30 & 7,90 & $-3,55 * *$ \\
\hline & 8.04 & 24,4 & bnlg1863 & $-0,54$ & $-0,01$ & $2,72 * * *$ & 0,14 & $-10,23$ 。 & $-0,31$ & $12,68 * *$ & $-1,65^{*}$ \\
\hline & 8.05 & 37,4 & bnlg1176 & $1,00_{\mathrm{o}}$ & 0,00 & $1,52 * *$ & $-0,32$ & $-2,58$ & 1,22 & 4,41 & $-1,64$ \\
\hline & 8.06 & 12,5 & bnlg1607 & $2,10 * *$ & 0,02 & $1,60 * * *$ & $-0,10$ & 8,55 & $1,66_{\circ}$ & 6,01 & $-0,31$ \\
\hline & 8.07 & 8,9 & bnlg1823 & $1,73^{*}$ & $-0,05$ & $1,36 * * *$ & 0,40 & 1,98 & $-0,12$ & 3,91 & 1,84 \\
\hline & 8.08 & 12,1 & umc1005 & $1,85 * * *$ & $-0,19$ & 0,23 & 0,12 & 4,29 & $-2,12 *$ & 3,52 & $-0,80$ \\
\hline & 8.09 & 15,6 & dupssr14 & $1,66 * * *$ & $-0,47$ & $-0,44$ & $-0,10$ & 0,39 & $-5,22 * *$ & $-0,65$ & $-2,05$ \\
\hline & 8.09 & & bnlg1131 & 0,49 & $-0,26$ & $-0,72 *$ & 0,30 & $-2,09$ & $-3,20$ & $-1,37$ & 0,46 \\
\hline \multirow[t]{10}{*}{9} & 9.02 & 2,4 & umc 1170 & $-0,80 *$ & $-0,09$ & $1,82 * * *$ & $-0,99 * *$ & $-1,11$ & $-0,10$ & $13,09 *$ & $-5,14 *$ \\
\hline & 9.02 & 11,8 & dupssr06 & $-0,82 *$ & $-0,14$ & $1,56 * * *$ & $-0,79 * *$ & $-0,02$ & $-1,52$ & $10,57 *$ & $-3,12^{*}$ \\
\hline & 9.02 & 4,7 & bnlg1401 & $-1,89 * * *$ & 0,06 & $2,06 * * *$ & $-0,99 * * *$ & $-5,30$ & $-0,69$ & $11,05 *$ & $-3,75^{* *}$ \\
\hline & 9.02 & 14,0 & umc1893 & $-1,73 * *$ & $-0,01$ & $1,79 * * *$ & $-0,73 *$ & $-5,70$ & $-0,63$ & $10,41 *$ & $-1,17$ \\
\hline & 9.03 & 12,3 & bnlg0430 & $-2,22 * *$ & 0,30 & 0,70 & $-0,82 * *$ & $-10,13 *$ & 2,13 & 1,49 & $-1,95$ \\
\hline & 9.04 & 5,6 & umc1107 & $-1,81 * *$ & 0,26 & 0,94 & $-0,39 * *$ & $-9,96 * * *$ & $-0,33$ & 3,66 & 0,43 \\
\hline & 9.05 & 34,1 & bnlg1012 & $-1,56^{*}$ & 0,30 & 0,59 & $-0,41 * *$ & $-10,78 * *$ & $-1,06$ & 3,82 & 0,23 \\
\hline & 9.06 & 13,8 & umc1733 & 0,04 & 0,20 & 0,26 & 0,38 & 4,05 & 3,19 & 3,86 & 1,06 \\
\hline & $9.07-08$ & 7,8 & bnlg0619 & $-0,21$ & 0,21 & 0,32 & $-0,28$ & $-0,53$ & 1,64 & 6,42 & 1,32 \\
\hline & 9.07 & & bnlg0128 & $-0,26$ & 0,20 & 0,14 & $-0,10$ & $-2,54$ & 2,75 & 4,53 & 1,28 \\
\hline \multirow[t]{12}{*}{10} & 10.00 & 9,8 & phi0117 & $-1,18 * *$ & $-0,05$ & $1,29^{*}$ & 0,23 & $-9,87 * *$ & $-1,69$ & 3,39 & 0,16 \\
\hline & 10.01 & 6,3 & umc1319 & $-1,44 * *$ & $-0,25$ & $2,21 * *$ & 0,22 & $-15,07 * * *$ & $-3,63^{*}$ & $8,01 *$ & 0,07 \\
\hline & 10.02 & 40,7 & bnlg 1451 & $-1,48 * *$ & $-0,37$ & $2,08 * *$ & $-0,37$ & $-14,10 * *$ & $-2,20$ & $8,60 * *$ & $-1,52_{\mathrm{o}}$ \\
\hline & 10.03 & 7,3 & bnlg0640 & $-0,95 *$ & $-0,17$ & $2,47 * *$ & $-0,23$ & $-14,18 *$ & $-1,12$ & 5,50 & $-2,90^{*}$ \\
\hline & 10.04 & 27,0 & bnlg1526 & $-0,59$ & $-0,23$ & $2,88 * *$ & $-0,11$ & $-11,59$ 。 & 1,14 & $9,29 *$ & $-3,89 * *$ \\
\hline & 10.05 & 7,0 & umc1930 & $-0,79$ & $-0,08$ & $3,78 * * *$ & $-0,34$ & $-4,45$ & 0,57 & $5,37 *$ & $-0,53$ \\
\hline & 10.05 & 12,1 & umc1506 & $-1,81 *$ & $-0,16$ & $4,68 * * * *$ & $-0,18$ & $-5,49$ & $-3,22$ & $9,29 * *$ & 0,75 \\
\hline & 10.07 & 0,2 & umc1196 & $-4,92 * * *$ & 0,10 & $5,02 * * *$ & 0,10 & $-9,71$ & $-1,24$ & 6,57 & $-0,17$ \\
\hline & 10.07 & 0,1 & umc1038 & $-5,17 * * *$ & 0,13 & $4,90 * * *$ & 0,16 & $-10,70$ & $-1,58$ & 7,30 & 0,88 \\
\hline & 10.07 & 0,1 & umc 2021 & $-4,84 * * *$ & 0,18 & $4,62 * * *$ & 0,21 & $-7,97$ 。 & $-0,92$ & $6,02^{*}$ & 0,90 \\
\hline & 10.07 & 1,4 & umc1569 & $-4,39 * *$ & $-0,09$ & $5,73 * * *$ & $0,46 *$ & $-5,35$ 。 & $-3,21 *$ & $11,19 *$ & 0,60 \\
\hline & 10.07 & & bnlg1839 & $-4,03 * *$ & $-0,04$ & $4,37 * * *$ & $-0,08$ & $-9,40$ & $-4,37 *$ & 4,83 & 1,05 \\
\hline
\end{tabular}

${ }^{a}$ número do cromossomo; ${ }^{b}$ distância em centiMorgan $(\mathrm{cM})$ entre locos adjacentes; ${ }^{c}$ Níveis de significância dos efeitos dos contrastes: * $\mathrm{R} 0,05$; ** $\mathrm{P} \leq 0,01$; *** $\mathrm{P} \leq 0,001$; **** $\mathrm{P} \leq 0,0001 \mathrm{e} * * * * *$ $\mathrm{P} \leq 0,00001$; níveis de significância das interações contrastes por ambientes: o $\mathrm{R} 0,05$; oo $\mathrm{P} \leq 0,01$; ${ }^{\mathrm{d}}$ estimativas dos efeitos de prolificidade (PRO) multiplicadas por $10^{-3}$. 
Tabela 9. Estimativas e significâncias dos coeficientes de regressão parciais ( $\left.\hat{a}^{\prime} s\right)$ para os caracteres diâmetro da espiga (DE) e comprimento da espiga (CE).

\begin{tabular}{|c|c|c|c|c|c|c|c|c|c|c|c|}
\hline \multirow{2}{*}{$C^{\mathrm{a}}$} & \multirow{2}{*}{ Bin } & \multirow{2}{*}{$\mathrm{cM}^{\mathrm{b}}$} & \multirow{2}{*}{ Marcador } & \multicolumn{4}{|c|}{$\mathrm{DE}^{\mathrm{d}}\left(\mathrm{cm} \mathrm{esp} .^{-1}\right)$} & \multicolumn{4}{|c|}{$\mathrm{CE}^{\mathrm{e}}\left(\mathrm{cm} \mathrm{esp} .^{-1}\right)$} \\
\hline & & & & $\hat{a}_{1}^{c}$ & $\hat{a}_{2}$ & $\hat{a}_{3}$ & $\hat{a}_{4}$ & $\hat{a}_{1}$ & $\hat{a}_{2}$ & $\hat{a}_{3}$ & $\hat{a}_{4}$ \\
\hline \multirow[t]{19}{*}{1} & 1.01 & 10,7 & umc ITTT & 3,95 & $-4,64$ & $8,57 *$ & 1,72 & $-2,75^{*}$ & $-0,56$ & $3,60^{*}$ & $1,80 * *$ \\
\hline & 1.01 & 0,9 & bnlg1014 & 7,74 & $-3,64$ & $9,31 *$ & 0,57 & $-1,13$ & 0,75 & 2,51 & 1,79 \\
\hline & 1.00 & 19,8 & umc1106 & 5,39 & $-3,83$ & $10,33 *$ & $-0,29$ & $-1,53$ & $1,30 *$ & $4,33 *$ & 1,74 \\
\hline & 1.02 & 11,4 & bnlg1627 & 6,37 & 3,59 & 8,19 & $-2,01 *$ & $-5,55^{*}$ & $2,02 *$ & $5,36 * *$ & $-0,29$ \\
\hline & 1.02 & 5,7 & bnlg1083 & 0,76 & $-1,37$ & $9,32 * *$ & 0,05 & $-2,34$ & $2,45 * * *$ & $4,56 * *$ & $-0,12$ \\
\hline & 1.03 & 9,9 & umc 1073 & 3,66 & $-6,98^{*}$ & $7,32 * *$ & 2,67 & $-3,59$ & $1,68^{*}$ & $5,74 * * *$ & 0,51 \\
\hline & 1.03 & 8,7 & umc1021 & 5,97 & $-1,37$ & $16,43 * *$ & $-0,04$ & $-7,93^{*}$ & 0,99 & $6,11 * *$ & 0,94 \\
\hline & 1.04 & 21,9 & bnlg2238 & 6,78 & $-1,6 \mathrm{C}$ & $8,91 *$ & $-1,14$ & 1,45 & 1,33 & $3,56^{*}$ & $-0,36$ \\
\hline & 1.05 & 13,1 & umc2025 & 1,08 & $-2,49$ & $14,81 *$ & $-6,13 * *$ & 3,81 & $1,46^{* *}$ & $7,28 * *$ & $-0,27$ \\
\hline & 1.05 & 10,7 & umc1601 & 5,13 & $-2,84$ & 8,28 & $-3,05$ & $-0,02_{0}$ & $-0,35$ & $8,28^{*}$ & $-0,10$ \\
\hline & 1.06 & 5,7 & umc1508 & $-0,42$ & $-2,63$ & 3,85 & $-3,56$ & $-0,07_{\text {о о о о о }}$ & 1,44 & $7,24 *$ & 0,25 \\
\hline & 1.06 & 6,8 & bnlg 1598 & $-5,12$ & $-4,18^{*}$ & 2,39 & $-1,57$ & $0,26_{\circ}$ & 1,42 & $8,73^{*}$ & $-0,34$ \\
\hline & 1.06 & 25,6 & umc1035 & $-1,53$ & $-1,41$ & 8,77 & $2,21 * *$ & $-2,57$ o & 0,15 & $8,62 *$ & 1,24 \\
\hline & 1.07 & 15,9 & bnlg0615 & $18,62 *$ & $-1,08$ & $11,07 * *$ & 0,89 & 3,25 & $-1,01$ & 5,10 & 0,05 \\
\hline & 1.10 & 24,1 & umc1431 & $-4,08$ & $4,63_{0}$ & 3,76 & $-0,80$ & 2,91 & $-4,22 * *$ & 2,79 & $-0,45$ \\
\hline & 1.08 & 24,2 & phi0037 & 6,87 & 2,06 & $8,74 *$ & $5,22 * *$ & $-4,09 * *$ & 0,14 & $9,33 * *$ & 1,59 \\
\hline & 1.11 & 11,6 & phi0120 & $-7,14_{\text {ooo }}$ & $6,26^{*}$ & 2,37 & $-1,58$ & $11,77 * * *$ & $-1,74$ & 0,35 & $-2,88 * *$ \\
\hline & 1.11 & 17,6 & umc1630 & $-7,09_{\text {oоo }}$ & $5,60 *$ & 0,11 & 0,89 & $13,20 * * * * *$ & $-0,92$ & 1,74 & $-1,15$ \\
\hline & 1.12 & & umc1605 & 8,28 。 & 1,86 & 1,37 & $-1,43$ & $6,85^{*}$ & 1,36 & 1,34 & 0,89 \\
\hline \multirow[t]{19}{*}{2} & 2.01 & 4,6 & umc1165 & $-0,01$ & 1,36 & 7,40 & 1,23 & $-3,47$ & $-1,09$ & 0,37 & 1,81 \\
\hline & 2.01 & 1,3 & bnlg 1338 & 2,48 & 0,65 & $8,11 *$ & 1,92 & $-3,87$ & $-2,28 * * * *$ & $3,54 *$ & 1,37 \\
\hline & 2.01 & 1,5 & umc1227 & 4,22 & 0,44 & 4,16 & 2,11 & $-4,22$ & $-2,47 * *$ & 1,72 & 1,22 \\
\hline & 2.02 & 2,8 & bnlg 1017 & 3,82 & $0,0 y$ & 3,46 & 3,49 & $-3,14$ & $-3,17 * * *$ & $2,56 * *$ & 1,67 \\
\hline & 2.02 & 12,9 & umc1265 & 9,53 & $-0,91$ & 3,40 & 2,49 & $-5,02$ & $-3,03 * *$ & $2,91 * *$ & 1,06 \\
\hline & 2.02 & 8,6 & umc1934 & $13,43 * *$ & $-1,35$ & 5,75 & 3,34 & $-7,51 * *$ & 1,11 & 3,84 & 0,59 \\
\hline & 2.02 & 4,0 & bnlg0125 & $24,88 * *$ & 0,52 & $-0,76$ & $4,29 * *$ & $-1,87_{\mathrm{o}}$ & 0,45 & 4,37 & 0,48 \\
\hline & 2.03 & 0,9 & umc1845 & $23,56 * *$ & $-4,27$ & 6,47 & 0,57 & $-0,38$ & 1,50 & $7,97 * *$ & $-1,39$ \\
\hline & 2.03 & 2,5 & umc1776 & $30,25 * *$ & $-0,45$ & 6,32 & 0,95 & 1,69 & 1,09 & $7,13^{*}$ & 0,05 \\
\hline & 2.03 & 7,1 & bnlg 2248 & $21,82 * *$ & $-5,53$ & $8,39 *$ & 2,54 & $-3,23$ & $3,42 *$ & $6,91 *$ & $-0,11$ \\
\hline & 2.03 & 32,2 & bnlg0381 & $26,16 * * *$ & $-1,43$ & $-1,88$ & 3,35 & 4,39 & 1,58 & $8,39 *$ & $-0,13$ \\
\hline & 2.04 & 10,1 & bnlg0166 & $-8,75$ & $-3,11^{*}$ & $-5,89 *$ & $-0,90$ & $8,05 * * *$ & $5,21 * * *$ & $5,49 *$ & $-0,55$ \\
\hline & 2.05 & 19,5 & dupssr21 & $-18,54 * *$ & $-0,07$ & $-0,20$ & 3,18 & $11,77 * * *$ & $3,42 * *$ & $4,79 *$ & $1,07 * *$ \\
\hline & 2.06 & 78,3 & bnlg1396 & $-11,82_{0}$ & 1,12 & 1,27 & 1,62 & $5,83 * *$ & $2,60^{*}$ & 2,06 & 0,90 \\
\hline & 2.07 & 6,3 & umc1560 & $-0,44$ & $-6,67 * *$ & 4,14 & $-1,82$ & $-1,50$ & $2,58 *$ & $6,44 * *$ & $-1,36$ \\
\hline & 2.08 & 6,5 & umc1464 & $-4,90$ & $-1,57$ & $11,78 * *$ & $-1,03$ & $-3,35$ & 1,48 & $9,71 * * *$ & 0,43 \\
\hline & 2.08 & 6,9 & umc1633 & $-3,15$ & $2,68^{*}$ & $10,72 * *$ & 0,67 & $-1,66$ & 1,48 & $7,47 * * *$ & 0,32 \\
\hline & 2.09 & 4,9 & umc1230 & $-2,42$ & $-1,02$ & 8,14 & $-0,19$ & $-4,62 *$ & 1,87 & $6,45 * * * *$ & $1,50 *$ \\
\hline & 2.09 & & bnlg 1520 & 0,93 & $0,5 \mathrm{C}$ & 5,89 & $-1,59$ & $-5,10 *$ & 1,91 & $5,98 * * * *$ & 0,39 \\
\hline \multirow[t]{13}{*}{3} & 3.01 & 17,4 & umc1394 & $-17,72 * *$ & $-3,53$ & 3,91 & 1,45 & 2,91 & 0,51 & $-1,46$ & $-1,04$ \\
\hline & 3.03 & 27,7 & bnlg1144 & 2,39 & $-0,66$ & $14,21 * *$ & $2,22 *$ & 0,01 & 3,71 ***** & 2,71 & $-1,86$ \\
\hline & 3.04 & 7,8 & bnlg1452 & $16,82 * *$ & $-0,87$ & $21,00 * * *$ & $-0,90$ & $-4,64 *$ & $-0,50$ & 4,59 & $-0,41$ \\
\hline & 3.04 & 12,1 & bnlg602 & $20,87 * *$ & $-0,09$ & $22,29 * * *$ & 2,12 & $-2,78$ & 1,74 & 6,50 & 0,17 \\
\hline & 3.05 & 1,8 & bnlg0420 & $15,37 *$ & $-0,69$ & $13,92 * *$ & $-0,28$ & $-5,22^{*}$ & $-0,18$ & $4,36^{*}$ & $-0,63$ \\
\hline & 3.05 & 34,1 & $\mathrm{mmc} 0022$ & $14,68 *$ & $-1,08$ & $16,13 * *$ & 0,75 & $-3,48$ & $-0,51$ & $4,98^{* *}$ & $-0,52$ \\
\hline & 3.06 & 28,6 & bnlg 1798 & $-16,03^{*}$ & 1,58 & $9,80 *$ & $5,10 * *$ & $8,08 * *$ & $-1,95$ & $-0,32$ & 0,78 \\
\hline & 3.07 & 3,3 & umc1690 & $-10,11$ & $-3,15^{* *}$ & 5,12 & $-2,72$ & $10,56 * * *$ & $-2,52 *$ & $-1,53$ & $-2,96 *$ \\
\hline & 3.07 & 16,0 & umc1659 & $-7,62$ & 0,47 & 2,86 & $-2,83$ & $9,23 * * *$ & $-3,45 * * *$ & $-1,64$ & $-2,69 * * *$ \\
\hline & 3.08 & 14,1 & umc1320 & $-6,02$ & 0,93 & 9,67 & $-0,42$ & $4,98 *$ & 0,23 & 4,43 & 0,20 \\
\hline & 3.09 & 2,9 & bnlg1536 & $-0,18$ & $-2,67$ & 2,39 & $-1,04$ & 3,04 & $3,13 * *$ & 2,26 & 0,55 \\
\hline & 3.09 & 26,7 & bnlg1754 & 3,37 & $-5,44 * *$ & 1,67 & $-4,41$ & 4,46 & $3,77 * *$ & 4,08 & $-1,40$ \\
\hline & 3.10 & & bnlg1098 & $-5,35$ & $-8,11^{* * *}$ & $-9,73 * *$ & $-5,76 *$ & 3,51 & $4,65 * *$ & 1,33 & $-1,19 *$ \\
\hline
\end{tabular}


Tabela 9. Estimativas e significâncias dos coeficientes de regressão parciais ( $\left.\hat{a}^{\prime} s\right)$ para os caracteres diâmetro da espiga (DE) e comprimento da espiga (CE).

\begin{tabular}{|c|c|c|c|c|c|c|c|c|c|c|c|}
\hline \multirow{2}{*}{$\mathrm{C}^{\mathrm{a}}$} & \multirow{2}{*}{ Bin } & \multirow{2}{*}{$\mathrm{cM}^{\mathrm{b}}$} & \multirow{2}{*}{ Marcador } & \multicolumn{4}{|c|}{$\mathrm{DE}^{\mathrm{d}}\left(\mathrm{cm} \mathrm{esp} .^{-1}\right)$} & \multicolumn{4}{|c|}{$\mathrm{CE}^{\mathrm{e}}\left(\mathrm{cm} \mathrm{esp} .^{-1}\right)$} \\
\hline & & & & $\hat{a}_{1}^{c}$ & $\hat{a}_{2}$ & $\hat{a}_{3}$ & $\hat{a}_{4}$ & $\hat{a}_{1}$ & $\hat{a}_{2}$ & $\hat{a}_{3}$ & $\hat{a}_{4}$ \\
\hline \multirow[t]{19}{*}{4} & 4.01 & 55,7 & umcl276 & 7,51 & $-1,91$ & 9,07 * & $-0,45$ & $3,64^{*}$ & $2,20^{*}$ & $4,49^{*}$ & 0,57 \\
\hline & 4.04 & 3,4 & umc1652 & $-7,59$ & $4,45^{*}$ & 3,69 & $-0,88$ & 1,86 & 0,73 & 5,37 & 0,73 \\
\hline & 4.05 & 0,1 & phi0026 & $-14,15 *$ & $4,74^{*}$ & 2,05 & $-2,09$ & 3,41 & 0,36 & 4,03 & $-0,45$ \\
\hline & 4.05 & 1,7 & umc1088 & $-10,48$ & $4,58^{*}$ & 3,37 & $-1,01$ & 3,04 & $-0,01$ & 4,95 & 0,70 \\
\hline & 4.06 & 35,6 & bnlg0252 & $-13,41 *$ & $3,1 \mathrm{C}$ & 2,10 & $-1,59$ & 3,84 & 1,48 & 4,57 & 0,37 \\
\hline & 4.07 & 5,1 & bnlg2291 & $-9,00 * * *$ & $-0,29$ & $6,38 *$ & $-0,28$ & $8,93^{* * *}$ & $-1,48^{*}$ & $5,63 * *$ & $-1,73^{*}$ \\
\hline & 4.07 & 18,0 & dupssr34 & $-8,84 * *$ & $-1,3 \mathrm{C}$ & 5,03 & 0,63 & $7,80 * *$ & $-2,27 *$ & $4,38 * *$ & $-1,55 *$ \\
\hline & 4.08 & 2,0 & bnlg2244 & $-1,97$ & $-1,2 \mathrm{C}$ & 7,36 & $-2,02 * *:$ & $-0,05$ & $-0,60$ & $6,91^{* *}$ & $-1,26$ \\
\hline & 4.08 & 4,7 & bnlg2162 & $-4,44$ & $-2,46$ & 3,12 & $-3,35 * *$ & 0,33 & $-0,36$ & $6,07 *$ & $-1,84 *$ \\
\hline & 4.08 & 4,6 & umc1086 & 1,92 & $-0,32$ & 7,48 & $-1,50$ & 3,10 & $-1,24$ & $9,13 * * * *$ & $-0,48$ \\
\hline & 4.08 & 11,5 & umc1051 & 1,38 & 0,08 & 7,07 & 0,43 & 0,30 & $-3,11 *$ & $5,95 * *$ & $-0,60$ \\
\hline & 4.09 & 15,6 & umc1989 & $-4,13$ & $-2,51$ & 4,34 & $3,08 * * *$ & 1,16 & $-2,63 * *$ & 1,40 & $0,71 *$ \\
\hline & 4.09 & 0,6 & phi314704 & $-5,76 * *$ & $-4,19 *$ & 1,40 & $-1,20$ & 0,76 & $-0,95$ & $-1,86$ & $-0,48$ \\
\hline & 4.11 & 0,2 & bnlg0589 & 0,62 & $-1,96$ & 1,23 & $-0,73$ & $4,48^{*}$ & 0,89 & $-2,39$ & $-0,94$ \\
\hline & 4.10 & 0,2 & umc1503 & $-4,76 * *$ & $-2,95$ & 2,58 & $-0,95$ & 1,19 & $-1,03$ & $-1,16$ & $-0,26$ \\
\hline & 4.10 & 5,9 & umc1532 & $-5,08 * * *$ & $-2,15$ & 1,82 & $-0,65$ & 1,24 & $-1,13$ & $-0,70$ & 0,07 \\
\hline & 4.10 & 6,3 & umc1109 & $-7,95^{*}$ & $-4,78^{*}$ & 0,05 & $-4,95$ & 1,08 & $-1,40$ & $-2,77$ & $-1,52$ \\
\hline & 4.11 & 6,2 & bnlg1337 & $-2,75$ & $-4,54 * *$ & $-0,01$ & $-2,27$ & $-0,18$ & $-0,45$ & $-2,30$ & $-0,22$ \\
\hline & 4.11 & & umc1197 & $-3,45$ & $-5,94 *$ & 2,31 & $-2,08$ & 0,73 & $-0,01$ & $-3,14$ & $-0,99 *$ \\
\hline \multirow[t]{16}{*}{5} & 5.00 & 40,7 & bnlg1006 & $-0,03$ & $-2,41$ & 1,08 & 0,97 & $5,67^{*}$ & $-0,21$ & $4,17 *$ & $-1,25 * *$ \\
\hline & 5.02 & 8,3 & umc1587 & $9,70 *$ & $-2,02$ & 6,68 & 1,70 & $-7,46^{* *}$ & $-1,45$ & $5,69 *$ & 0,76 \\
\hline & $5.03-04$ & 45,3 & phi0113 & $14,87 * *$ & $-2,1 \mathrm{C}$ & 7,57 & 1,78 & $-7,59 * *$ & $-2,28 *$ & $6,81 * *$ & 1,36 \\
\hline & 5.03 & 16,1 & bnlg 1879 & $13,14 * *$ & $-3,93^{*}$ & $7,96 *$ & 1,50 & $-6,39 *$ & $-0,59$ & $8,05 * *$ & 1,18 \\
\hline & 5.03 & 14,1 & umc1056 & $22,36 * * *$ & 2,06 & 6,97 & 1,45 & $-4,22$ & 1,49 & $8,99 * * *$ & $-1,09$ \\
\hline & 5.03 & 9,7 & bnlg1902 & $26,34 * * *$ & 3,28 & $10,37 *$ & $-1,57$ & $-6,44$ & $2,07 *$ & $10,77 * *$ & $-1,95 *$ \\
\hline & 5.04 & 17,7 & dupssr10 & $27,17 * * *$ & $5,64 * *$ & $16,99 * *$ & $-1,71$ & $-5,81 *$ & 1,84 & $9,55 * *$ & $-1,37$ \\
\hline & 5.04 & 3,8 & umc1221 & $24,13 * * *$ & $-4,01^{*}$ & $12,00 *$ & $-1,59$ & $-5,85^{*}$ & $-0,65$ & $6,89 * *$ & $-2,03 *$ \\
\hline & 5.05 & 23,5 & $\mathrm{mmc} 0081$ & $21,60 * * *$ & $-1,19$ & $9,88 *$ & $-3,56 *$ & $-7,80 * *$ & $-0,28$ & $6,48^{* *}$ & $-3,02 * *$ \\
\hline & 5.06 & 2,1 & umc1019 & $19,02 * * *$ & $-2,22$ & 1,30 & $-1,58$ & $-1,49$ & $-1,53$ & $-0,01$ & $-0,63$ \\
\hline & 5.06 & 2,3 & $\mathrm{mmc} 0481$ & $20,32 * * *$ & $-3,18$ & $4,52 *$ & $-0,93$ & $-1,97$ & $-0,55$ & 1,83 & $-0,17$ \\
\hline & $5.05-06$ & 61,6 & bnlg278 & $19,19 * *$ & $-4,48 *$ & 0,43 & $-0,42$ & $-1,54$ & $-0,21$ & $-0,04$ & $-0,47$ \\
\hline & 5.06 & 0,1 & umc1680 & $21,71 * * *$ & $-3,28^{*}$ & 1,80 & $-1,27$ & $-1,92$ & $-0,50$ & $-0,37$ & $-0,31$ \\
\hline & 5.06 & 21,9 & umc1524 & $20,73 * *$ & $-3,5 C^{\prime *}$ & 3,29 & $-1,28$ & $-0,08$ & $-0,47$ & $-0,94$ & $-0,31$ \\
\hline & 5.07 & 32,3 & phi0128 & $17,85 * *$ & $-1,28$ & 1,14 & 0,28 & $-0,35$ & $-1,16^{*}$ & 1,36 & $-0,10$ \\
\hline & 5.09 & & umc1153 & $8,15 * * *$ & 3,77 & $-6,98$ & $-2,18 * *$ & $-3,02$ & $1,52 *$ & $-2,15$ & $-1,03 *$ \\
\hline \multirow[t]{12}{*}{6} & 6.00 & 34,3 & phi0126 & 4,87 & $-3,15$ & $-0,33$ & $-0,97$ & 1,50 & 0,45 & $5,00^{*}$ & $-2,76^{*}$ \\
\hline & 6.02 & 14,3 & bnlg 1371 & $-7,27 *$ & 2,76 & $9,27 *$ & $-0,64$ & $-1,26$ & 0,06 & 5,60 & $-0,64$ \\
\hline & 6.01 & 9,9 & phi0077 & $-11,51$ & $0,6 \mathrm{C}$ & $13,26 *$ & 1,70 & $-1,92$ & 1,38 & $9,13 * *$ & $-1,01$ \\
\hline & 6.02 & 0,8 & umc1006 & $-10,87_{o}$ & $-2,95^{*}$ & 4,44 & 0,67 & $-0,85$ & 0,70 & 3,13 & $-2,55$ o \\
\hline & 6.02 & 13,1 & umc1257 & $-13,88_{\text {oo }}$ & $-2,81 * *$ & 4,82 & 0,22 & $-2,51$ & 1,12 & 4,13 & $-2,45$ o \\
\hline & 6.03 & 13,9 & umc1887 & $-19,43^{*}$ & $-5,29 * *$ & $11,15 * *$ & 1,86 & 0,51 & 0,22 & $5,03 * *$ & $-1,06$ \\
\hline & 6.04 & 18,9 & umc1614 & $-20,30 * * *$ & $-4,05 * * *$ & $9,84 *$ & $-1,17$ & $5,29 *$ & 1,19 & 4,16 & $-0,10$ \\
\hline & 6.05 & 22,4 & nc0013 & $-14,63 * *$ & 0,51 & $-0,36$ & $-3,44$ & 4,07 & $-0,04$ & 1,53 & 0,61 \\
\hline & 6.06 & 21,2 & umc1520 & $-15,16^{*}$ & 2,45 & 4,52 & $-0,42$ & $5,99^{*}$ & $-2,42 *$ & 3,61 & $-0,08$ \\
\hline & 6.07 & 11,5 & bnlg 1759 & $-8,61^{*}$ & $-2,84$ & 0,98 & $-2,67 *$ & $-3,93$ & 0,32 & 2,06 & $-1,14$ \\
\hline & 6.07 & 2,6 & umc1653 & $-7,12$ & $-3,03$ & 1,94 & 0,19 & $-1,45$ & $-1,03$ & 1,64 & 0,97 \\
\hline & 6.08 & & umc1127 & $-6,35$ & $-3,44$ & 2,62 & 2,00 & $-1,83$ & $-1,61$ & 1,11 & 0,90 \\
\hline
\end{tabular}


Tabela 9. Estimativas e significâncias dos coeficientes de regressão parciais ( $\hat{a}^{\prime}$ s) para os caracteres diâmetro da espiga (DE) e comprimento da espiga (CE).

\begin{tabular}{|c|c|c|c|c|c|c|c|c|c|c|c|}
\hline \multirow{2}{*}{$\mathrm{C}^{\mathrm{a}}$} & \multirow{2}{*}{ Bin } & \multirow{2}{*}{$\mathrm{cM}^{\mathrm{b}}$} & \multirow{2}{*}{ Marcador } & \multicolumn{4}{|c|}{$\mathrm{DE}^{\mathrm{d}}\left(\mathrm{cm} \mathrm{esp} .^{-1}\right)$} & \multicolumn{4}{|c|}{$\mathrm{CE}^{\mathrm{e}}\left(\mathrm{cm} \mathrm{esp} .^{-1}\right)$} \\
\hline & & & & $\hat{a}_{1}{ }^{c}$ & $\hat{a}_{2}$ & $\hat{a}_{3}$ & $\hat{a}_{4}$ & $\hat{a}_{1}$ & $\hat{a}_{2}$ & $\hat{a}_{3}$ & $\hat{a}_{4}$ \\
\hline \multirow[t]{9}{*}{$T$} & 7.00 & 34,5 & umc1426 & $7,74 \%$ & $-2,93$ & $-1,88$ & 0,15 & 1,71 & $3,38 \%$ & $-0,19$ & $-0,12$ \\
\hline & 7.01 & 7,6 & umc1632 & $-9,11^{*}$ & $-5,16^{*}$ & 5,61 & $-1,58$ & $-5,36^{* *}$ & 1,26 & $10,20 * * *$ & $-2,52 * *$ \\
\hline & 7.01 & 0,1 & umc1409 & $-9,65 * *$ & $-5,24 * *$ & 6,62 & $-2,89$ & $-7,69 * * *$ & $-0,77$ & $11,25 * * * *$ & $-2,17 * * *$ \\
\hline & 7.02 & 28,3 & bnlg1094 & $-7,26^{*}$ & $-5,24 * *$ & 6,54 & $-2,68$ & $-8,01 * * *$ & $-0,73$ & $11,12 * * * *$ & $-1,99 * *$ \\
\hline & 7.03 & 39,7 & bnlg0434 & $-1,89$ & 0,27 & $7,72 *$ & 1,54 & 1,87 & 0,45 & $11,26 * * * * *$ & $-0,80$ \\
\hline & 7.04 & 32,6 & dupssr13 & $-12,25 *$ & $5,82^{*}$ & $-1,21$ & $-1,78$ & $5,81^{*}$ & 1,25 & $4,34^{*}$ & 0,79 \\
\hline & 7.05 & 3,2 & umc1154 & $-2,71$ & $5,73^{*}$ & $-10,35 *$ & $-3,26$ & $12,44 * * *$ & $-0,39$ & $-4,03^{*}$ & $-3,18 * * *$ \\
\hline & 7.05 & 6,7 & umc1407 & 1,09 & $6,35_{\mathrm{o} \text { o }}$ & $-9,07$ & 0,29 & 7,77 ** & 1,26 & 0,58 & $-1,73 *$ \\
\hline & 7.06 & & phi0116 & $-0,75$ & $6,53_{\mathrm{oo}}$ & $-10,01$ & 1,03 & $8,44 * *$ & 0,81 & $-1,14$ & $-1,31$ \\
\hline \multirow[t]{11}{*}{8} & 8.01 & 12,1 & umc1139 & 2,54 & 0,54 & $10,17 *$ & 0,69 & 0,22 & $-0,58$ & $8,07 * *$ & 1,06 \\
\hline & 8.00 & 14,5 & phi420701 & $9,71^{*}$ & $-1,38$ & $12,07 * *$ & 1,72 & $-0,41$ & $-2,22$ & $5,50 *$ & 0,74 \\
\hline & 8.02 & 11,9 & phi0119 & $23,08 * *$ & $-1,79$ & $12,83 * *$ & $-0,47$ & $-3,28$ & $-2,45^{*}$ & $6,64 * *$ & 0,47 \\
\hline & 8.03 & 22,0 & umc1034 & $26,48 * * *$ & $-2,45$ & $10,98 * *$ & $-2,71$ & $-6,89^{*}$ & 0,19 & $5,94 *$ & 0,43 \\
\hline & 8.04 & 24,4 & bnlg 1863 & 6,37 & $-1,47^{*}$ & $12,71 * *$ & 1,68 & $-0,35$ & $1,37 *$ & $7,29 * *$ & 1,87 *** \\
\hline & 8.05 & 37,4 & bnlg1176 & $19,76 * 0$ & 0,29 & 5,86 & $3,71 * * *$ & $-4,07$ & $-0,67$ & $6,87^{*}$ & $-1,44 * *$ \\
\hline & 8.06 & 12,5 & bnlg1607 & 6,96 & $-0,24$ & 6,72 & 1,21 & $-1,73$ & 0,18 & 2,70 & $-2,46^{*}$ \\
\hline & 8.07 & 8,9 & bnlg 1823 & $11,25 *$ & 1,13 & $8,63 * *$ & 1,11 & $-1,62$ & 1,49 & 3,29 & $-1,73$ \\
\hline & 8.08 & 12,1 & umc1005 & 8,53 & $-3,22$ & 6,99 & $-0,40$ & $-1,68$ & $1,87 *$ & $-0,21$ & $-1,18$ \\
\hline & 8.09 & 15,6 & dupssr14 & $9,36^{*}$ & $-2,43$ & 1,46 & $-0,84$ & $-1,16$ & $2,86 * *$ & $-1,45$ & 0,10 \\
\hline & 8.09 & & bnlg1131 & 2,89 & $-1,35$ & $-3,11$ & $-1,32$ & 2,19 & 0,95 & $-2,87$ & 1,71 \\
\hline \multirow[t]{10}{*}{9} & 9.02 & 2,4 & umc1170 & $-9,20$ & $-6,04^{*}$ & $5,43 *$ & $-4,61 *$ & $-4,11^{*}$ & $1,69 * *$ & 2,01 & $-1,17$ \\
\hline & 9.02 & 11,8 & dupssr06 & $-13,00 * *$ & $-5,04 *$ & $7,74 *$ & $-4,64 *$ & $-4,21 * *$ & $3,13 * *$ & 2,79 & $-1,83 *$ \\
\hline & 9.02 & 4,7 & bnlg1401 & $-15,70 * *$ & $-2,5 \mathrm{C}$ & 7,50 & $-5,49 *$ & $-3,08$ & $1,31 *$ & $6,26 * *$ & $-2,35 *$ \\
\hline & 9.02 & 14,0 & umc1 1893 & $-13,37 * *$ & $-2,48$ & 7,60 & $-5,28 *$ & $-2,72$ & 1,00 & $5,69 * *$ & $-2,15 * *$ \\
\hline & 9.03 & 12,3 & bnlg0430 & $-17,92 * *$ & $-1,90$ & 6,99 & $-3,01$ & $-3,04$ & 1,28 & $4,50 * *$ & $-1,96 * *$ \\
\hline & 9.04 & 5,6 & umc1107 & $-4,54$ & 1,09 & $7,65 *$ & $-1,44$ & $-8,08 *$ & 1,08 & $4,69 *$ & $-0,54$ \\
\hline & 9.05 & 34,1 & bnlg 1012 & 3,30 & $4,18^{*}$ & 0,63 & $-1,70$ & $-9,18^{* *}$ & $2,30 * *$ & $5,40 *$ & $-0,20$ \\
\hline & 9.06 & 13,8 & umc1733 & $-7,13$ & $-3,33$ & 1,73 & 3,83 & 0,27 & $3,15 * *$ & 3,34 & $-0,93$ \\
\hline & $9.07-08$ & 87,8 & bnlg0619 & $-3,04$ & $-5,05 * *$ & 2,00 & $-0,49$ & $-6,42 * *$ & $1,37 * *$ & $-0,71$ & $-1,44$ \\
\hline & 9.07 & & bnlg0128 & $-4,82$ & $-4,86 * *$ & 2,79 & 0,89 & $-7,05 * *$ & $-0,14$ & $-1,10$ & $-2,28 *$ \\
\hline \multirow[t]{12}{*}{10} & 10.00 & 9,8 & phi0117 & 2,56 & 2,84 & $7,09 * *$ & 0,13 & $-0,87$ & $1,74 * *$ & 4,13 & 1,12 \\
\hline & 10.01 & 6,3 & umc1319 & $11,25 * *$ & $3,32 *$ & $10,76 *$ & 0,78 & $3,78 * *$ & $1,73 * *$ & 6,23 & $1,74 *$ \\
\hline & 10.02 & 40,7 & bnlg1451 & $14,24 * *$ & 1,14 & $9,90 * *$ & $-2,80 * *$ & $2,46^{*}$ & 0,01 & 3,22 & 0,20 \\
\hline & 10.03 & 7,3 & bnlg0640 & $23,13 * * * *$ & 2,25 & $15,37 *$ & $-1,40$ & 1,06 & $-3,92 * * *$ & 2,69 & 0,70 \\
\hline & 10.04 & 27,0 & bnlg1526 & $24,89 * * * * *$ & $-1,62$ & $16,24 * *$ & 1,27 & 1,81 & $-2,31 *$ & 3,51 & $1,83 *$ \\
\hline & 10.05 & 7,0 & umc1930 & 2,40 & $-3,77^{*}$ & $22,17 * *$ & $-0,87$ & $-4,49 *$ & $1,51 *$ & $10,19 * * *$ & $-0,40$ \\
\hline & 10.05 & 12,1 & umc1506 & $-12,14 * *$ & $-2,64$ & $22,50 * *$ & 0,15 & $-6,34 *$ & $2,08 * *$ & $11,79 * *$ & $-0,24$ \\
\hline & 10.07 & 0,2 & umc1196 & $-38,14 * * *$ & $-2,1 \mathrm{C}$ & $20,21 * *$ & 1,73 & $-10,78 * * *$ & $4,73 * *$ & $18,79 * * *$ & $1,22 *$ \\
\hline & 10.07 & 0,1 & umc1038 & $-43,97 * * *$ & $-0,3 \mathrm{C}$ & $20,01 *$ & 0,88 & $-10,79 * *$ & $6,90 * * *$ & $19,46 * * *$ & 0,70 \\
\hline & 10.07 & 0,1 & umc2021 & $-39,81 * * *$ & $-0,67$ & $19,58 *$ & 1,35 & $-10,64 * * *$ & $4,58 * *$ & $18,03 * * *$ & 0,57 \\
\hline & 10.07 & 1,4 & umcl569 & $-30,98 * * *$ & $-2,6 \mathrm{C}$ & $22,95 *$ & $3,25 * * *$ & $-12,49 * * *$ & $7,22 * * *$ & $18,87 * * *$ & $1,70 *$ \\
\hline & 10.07 & & bnlg1839 & $-34,85 * *$ & $1,8 \mathrm{C}$ & $18,15 *$ & $-0,87$ & $-8,73 * * *$ & $4,93 * *$ & $17,26 * * *$ & 0,36 \\
\hline
\end{tabular}

${ }^{a}$ número do cromossomo; ${ }^{b}$ distância em centiMorgan $(\mathrm{cM})$ entre locos adjacentes; ${ }^{\mathrm{c}}$ Significância dos efeitos dos contrastes: * $\mathrm{P} \leq 0,05$; ** $\mathrm{P} \leq 0,01$; *** $\mathrm{P} \leq 0,001$; **** $\mathrm{P} \leq 0,0001$ e ***** $\mathrm{P} \leq 0,00001$; níveis de significância das interações contrastes por ambientes: o $\mathrm{P} \leq 0,05$; oo $\mathrm{P} \leq 0,01$; ${ }^{\mathrm{d}}$ estimativas dos efeitos multiplicadas por $10^{-3}$; e estimativas dos efeitos multiplicadas por $10^{-2}$. 
Tabela 10. Estimativas e significâncias dos coeficientes de regressão parciais (ấs) para os caracteres número de grãos por fileira (NGF) e número de fileiras por espiga (NFI).

\begin{tabular}{|c|c|c|c|c|c|c|c|c|c|c|c|}
\hline \multirow{2}{*}{$C^{\mathrm{a}}$} & \multirow{2}{*}{ Bin } & \multirow{2}{*}{$\mathrm{cM}^{\mathrm{b}}$} & \multirow{2}{*}{ Marcador } & \multicolumn{4}{|c|}{$\mathrm{NGF}^{\mathrm{e}}$} & \multicolumn{4}{|c|}{$\mathrm{NFI}^{\mathrm{e}}$} \\
\hline & & & & $\hat{a}_{1}{ }^{c}$ & $\hat{a}_{2}$ & $\hat{a}_{3}$ & $\hat{a}_{4}$ & $\hat{a}_{1}$ & $\hat{a}_{2}$ & $\hat{a}_{3}$ & $\hat{a}_{4}$ \\
\hline \multirow[t]{19}{*}{1} & 1.01 & 10,7 & umclit7 & 7,13 & 1,76 & $11,76^{* *}$ & $5,57 \% *$ & 2,66 & $-1,50$ & $1,2 \mathrm{C}$ & $-0,24$ \\
\hline & 1.01 & 0,9 & bnlg1014 & $11,96 *$ & 5,20 & $12,20 * * * *$ & 3,31 & $-0,45$ & $-0,47$ & 1,69 & 0,36 \\
\hline & 1.00 & 19,8 & umc1106 & $6,3 \mathrm{C}$ & 2,93 & $15,98 * * *$ & 3,23 & $-1,68$ & $-0,66$ & 1,89 & 0,35 \\
\hline & 1.02 & 11,4 & bnlg1627 & 4,27 & $7,84 * *$ & $18,79 * * *$ & 0,19 & 4,41 & $-0,47$ & 0,87 & $0,51 *$ \\
\hline & 1.02 & 5,7 & bnlg1083 & 11,21 & $8,28 * *$ & $20,07 * *$ & 0,37 & 3,84 & 0,00 & 0,17 & 0,27 \\
\hline & 1.03 & 9,9 & umc 1073 & 3,58 & 1,92 & $21,47 * *$ & 0,66 & $6,72^{*}$ & $-2,18^{* *}$ & $-1,46$ & 0,57 \\
\hline & 1.03 & 8,7 & umc1021 & $-19,12$ & $-4,67$ & $27,26 * * *$ & 0,42 & $19,02 * * *$ & 0,90 & $-0,17$ & $-0,65$ \\
\hline & 1.04 & 21,9 & bnlg2238 & $-5,21$ & $-4,60$ & $17,32 *$ & $-3,06$ & $17,17 * * *$ & $-0,78$ & $-1,42$ & $-1,75^{*}$ \\
\hline & 1.05 & 13,1 & umc2025 & $-11,66_{\mathrm{ooo}}$ & $-1,19$ & $23,25 * *$ & $-4,66$ & $9,12 * *$ & $-3,92 * *$ & 0,65 & $-1,04 *$ \\
\hline & 1.05 & 10,7 & umc1601 & $-19,48_{o o}$ & $-3,49$ & $24,32 * *$ & $-1,37$ & $10,29 * *$ & $-2,56 * *$ & $-1,37$ & $-0,21$ \\
\hline & 1.06 & 5,7 & umc1508 & $-28,21_{\mathrm{ooo}}$ & $-1,16$ & $21,75 * *$ & 0,95 & $8,90^{* *}$ & $-1,97^{*}$ & $-2,18$ & $-1,37 *$ \\
\hline & 1.06 & 6,8 & bnlg1598 & $-27,80^{*}$ оо & $-2,07$ & $23,36 * *$ & 0,33 & $7,35 * *$ & 0,09 & $-2,38^{*}$ & $-1,71$ \\
\hline & 1.06 & 25,6 & umc 1035 & $-8,93_{\mathrm{oo}}$ & 1,15 & $22,18 *$ & 3,87 & $9,62 * * * *$ & $2,21 *$ & $-0,49$ & $-0,09$ \\
\hline & 1.07 & 15,9 & bnlg0615 & 9,52 & $-1,41$ & $15,51 * *$ & $-0,64$ & $8,13^{* *}$ & 1,69 & $-0,92$ & 1,22 \\
\hline & 1.10 & 24,1 & umc1431 & 15,55 & $-3,79$ & 6,86 & $-3,31$ & $3,56 *$ & $2,23 * *$ & $-1,2 \mathrm{C}$ & $-0,37$ \\
\hline & 1.08 & 24,2 & phi0037 & $8,3 \mathrm{C}$ & 3,34 & $20,24 * * * *$ & 2,57 & 3,96 & $1,22 *$ & 1,13 & $2,44 * *$ \\
\hline & 1.11 & 11,6 & phi0120 & $25,08 * *$ & 3,60 & 4,25 & $-5,94 * *$ & $-0,54$ & $2,85^{*}$ & 0,45 & 0,57 \\
\hline & 1.11 & 17,6 & umc 1630 & $22,29 * *$ & 4,86 & 7,60 & $-3,71$ & 1,49 & $3,83 * *$ & 0,98 & $-0,11$ \\
\hline & 1.12 & & umc1605 & $13,38 *$ & 2,33 & $-1,12$ & 0,58 & $4,04 *$ & 1,24 & $2,81 * *$ & $-0,65$ \\
\hline \multirow[t]{19}{*}{2} & 2.01 & 4,6 & umc1165 & $-1,25$ & $-5,16$ & 7,78 & 3,54 & 1,86 & $1,94 *$ & $-0,56$ & $-0,38$ \\
\hline & 2.01 & 1,3 & bnlg 1338 & $-2,85$ & $-5,93 * *$ & $19,90 * *$ & 2,33 & $5,09 * *$ & 1,00 & $-1,27$ & 0,05 \\
\hline & 2.01 & 1,5 & umc1227 & $-5,1 \mathrm{C}$ & $-4,15^{*}$ & $13,08 *$ & 2,74 & 2,17 & 0,96 & $-2,06$ & $-0,28$ \\
\hline & 2.02 & 2,8 & bnlg 1017 & $-3,1 \mathrm{C}$ & $-5,54 *$ & $12,82 *$ & 3,81 & $4,11^{*}$ & 1,53 & $-2,16$ & $-0,12$ \\
\hline & 2.02 & 12,9 & umc1265 & $-3,37$ & $-8,74 * *$ & $15,14 * *$ & 3,38 & $5,8 \mathrm{C}^{*}$ & 1,58 & $-2,62$ & $-0,34$ \\
\hline & 2.02 & 8,6 & umc1934 & $-10,63$ & $-1,59$ & $25,40 * * *$ & 0,76 & $10,25 * *$ & 0,42 & $-1,51$ & 0,31 \\
\hline & 2.02 & 4,0 & bnlg0125 & $-7,07$ & 0,06 & $22,00 * *$ & $5,03 * * *$ & $17,51 * * *$ & $-1,04^{*}$ & $-2,9 \mathrm{C}$ & 1,01 \\
\hline & 2.03 & 0,9 & umc 1845 & $-14,89^{*}$ & 4,58 & $38,55 * * *$ & $-3,88 * *$ & $18,27 * * *$ & $-3,39 * * *$ & $-1,04$ & $-0,13$ \\
\hline & 2.03 & 2,5 & umc 1776 & $-14,47$ & 5,41 & $34,05 * *$ & 0,09 & $24,12 * * * *$ & $-2,23^{* *}$ & $-2,57$ & 0,18 \\
\hline & 2.03 & 7,1 & bnlg2248 & $-21,92^{*}$ & $8,64 *$ & $28,36 * *$ & $-0,78$ & $19,47 * * *$ & $-1,76^{* *}$ & $-1,63$ & 0,63 \\
\hline & 2.03 & 32,2 & bnlg0381 & $-2,92$ & 3,50 & $28,88 * *$ & $-1,19$ & $14,72 * *$ & $-0,70$ & $-3,15$ & 0,34 \\
\hline & 2.04 & 10,1 & bnlg0166 & 13,19 & 2,40 & $15,07 *$ & $-0,63$ & $-2,43$ & $-2,83^{* *}$ & $-0,82$ & 1,26 \\
\hline & 2.05 & 19,5 & dupssr21 & $18,42 * *$ & 1,92 & $15,42 *$ & 3,96 & $-5,02^{*}$ & 0,29 & 0,22 & 1,42 \\
\hline & 2.06 & 78,3 & bnlg1396 & $22,26 * *$ & 2,79 & 3,32 & 1,44 & $-0,32$ & 0,15 & $0,7 \mathrm{C}$ & 1,79 \\
\hline & 2.07 & 6,3 & umc 1560 & $-4,11$ & 2,20 & $20,00 * *$ & $-5,49$ & $11,38 * *$ & 0,09 & $-3,36$ & $-0,15$ \\
\hline & 2.08 & 6,5 & umc 1464 & $-2,31$ & $-1,34$ & $23,08 * *$ & 1,57 & $12,72 * *$ & $-0,28$ & $1,7 \mathrm{C}$ & $-0,23$ \\
\hline & 2.08 & 6,9 & umc1633 & $-2,84$ & $-0,48$ & $18,78 * *$ & 3,29 & $10,06 * * *$ & 1,04 & 0,98 & 0,43 \\
\hline & 2.09 & 4,9 & umc1230 & $-3,16$ & $-0,72$ & $15,33 *$ & $4,10 * *$ & $7,70 * * *$ & $1,39 * *$ & $-0,34$ & $-0,79$ \\
\hline & 2.09 & & bnlg 1520 & $-7,73$ & 0,05 & $12,51 * *$ & 1,36 & $9,34 * *$ & 1,15 & $-1,41$ & $-1,16$ \\
\hline \multirow[t]{13}{*}{3} & 3.01 & 17,4 & umc1394 & $12,29 *$ & 2,13 & $-3,88$ & 1,36 & $-3,17$ & $-0,28$ & 1,51 & $-0,47$ \\
\hline & 3.03 & 27,7 & bnlg1144 & $9,7 \mathrm{C}$ & $7,59 * *$ & $11,83 * *$ & $-2,57$ & $6,63^{*} *$ & $-1,18^{*}$ & 0,31 & $1,04 *$ \\
\hline & 3.04 & 7,8 & bnlg 1452 & $23,02 * *$ & 2,75 & $12,43 *$ & $-5,12 *$ & $9,17 * *$ & $-2,18 * *$ & $-0,89$ & 1,36 \\
\hline & 3.04 & 12,1 & bnlg602 & $15,72 *$ & 3,03 & $18,35 *$ & $-0,81$ & $7,85^{*}$ & $-1,59^{*}$ & $-1,06$ & 1,42 \\
\hline & 3.05 & 1,8 & bnlg0420 & $4,4 \mathrm{C}$ & 3,73 & $9,97 * *$ & $-2,70$ & 4,99 & $-2,29 *$ & $-1,53$ & 0,93 \\
\hline & 3.05 & 34,1 & $\mathrm{mmc} 0022$ & 7,12 & 4,76 & $11,57 * *$ & $-2,40$ & $7,30^{*}$ & $-1,04$ & $-1,86$ & 0,80 \\
\hline & 3.06 & 28,6 & bnlg1798 & $-1,04$ & $-1,05$ & 0,62 & 2,51 & 0,19 & $3,47 *$ & 0,07 & $-0,27$ \\
\hline & 3.07 & 3,3 & umc 1690 & 8,13 & $-12,00 * *$ & $-1,56$ & $-4,00^{*}$ & $-1,95$ & 0,34 & $-3,27 *$ & $-0,19$ \\
\hline & 3.07 & 16,0 & umc1659 & $-7,24$ & $-16,52 * * *$ & 0,08 & $-2,99 * *$ & $-4,60^{*}$ & 1,19 & $-2,88$ & $-0,43$ \\
\hline & 3.08 & 14,1 & umc1320 & $-9,59$ & $-6,73^{*}$ & $16,56 * *$ & 1,82 & $-7,31^{*}$ & 0,43 & 0,11 & $-0,45$ \\
\hline & 3.09 & 2,9 & bnlg 1536 & $-13,83^{*}$ & $-2,74$ & 5,86 & 0,46 & $-5,39 *$ & $-0,89$ & $-1,65$ & $-0,08$ \\
\hline & 3.09 & 26,7 & bnlg 1754 & $-7,22$ & 0,37 & 5,47 & $-5,53$ & $-6,81 * *$ & $-1,36$ & $-2,23$ & 0,01 \\
\hline & 3.10 & & bnlg1098 & 5,95 & 0,89 & $-1,52$ & $-2,48$ & $-7,17^{*}$ & $-1,75^{*}$ & $-1,98$ & $-2,51$ \\
\hline
\end{tabular}


Tabela 10. Estimativas e significâncias dos coeficientes de regressão parciais ( $\left.\hat{a}^{\prime} s\right)$ para os caracteres número de grãos por fileira (NGF) e número de fileiras por espiga (NFI).

\begin{tabular}{|c|c|c|c|c|c|c|c|c|c|c|c|}
\hline \multirow{2}{*}{$\mathrm{C}^{\mathrm{a}}$} & \multirow{2}{*}{ Bin } & \multirow{2}{*}{$\mathrm{cM}^{\mathrm{b}}$} & \multirow{2}{*}{ Marcador } & \multicolumn{4}{|c|}{$\mathrm{NGF}^{\mathrm{e}}$} & \multicolumn{4}{|c|}{$\mathrm{NFI}^{\mathrm{e}}$} \\
\hline & & & & $\hat{a}_{1}^{c}$ & $\hat{a}_{2}$ & $\hat{a}_{3}$ & $\hat{a}_{4}$ & $\hat{a}_{1}$ & $\hat{a}_{2}$ & $\hat{a}_{3}$ & $\hat{a}_{4}$ \\
\hline \multirow[t]{19}{*}{4} & 4.01 & 55,7 & umc 1276 & $-1,94$ & $-4,65$ & $18,51 \%$ & 2,81 & $8,04 * *$ & $-0,74$ & 2,56 & 0,67 \\
\hline & 4.04 & 3,4 & umc1652 & $-0,15$ & $9,32 *$ & $11,38 *$ & 0,63 & 1,83 & $-0,39_{0}$ & 0,68 & $-0,45$ \\
\hline & 4.05 & 0,1 & phi0026 & 5,58 & $7,71 *$ & 9,62 & $-2,70$ & $-2,16$ & $-0,83$ o & 0,24 & 0,02 \\
\hline & 4.05 & 1,7 & umc 1088 & $2,94_{0}$ & 5,19 & $10,93 *$ & 0,77 & $-0,36$ & $-0,73$ & 0,16 & $-0,18$ \\
\hline & 4.06 & 35,6 & bnlg0252 & 1,25 。 & 7,58 & 9,00 & $-1,74$ & $-0,72$ & $-0,53 \mathrm{o}$ & $-0,65$ & 0,08 \\
\hline & 4.07 & 5,1 & bnlg2291 & 6,55 & $-0,35$ & $10,63 *$ & $-5,36$ & 1,19 & $1,24^{*}$ & 2,34 & 0,85 \\
\hline & 4.07 & 18,0 & dupssr34 & 0,77 & $-2,24 \mathrm{o}$ & 5,65 & $-5,40 *$ & 1,45 & 0,35 & 2,39 & $1,53^{*}$ \\
\hline & 4.08 & 2,0 & bnlg2244 & $-5,66$ & 2,66 & 10,40 & $-9,01 *$ & $6,00 *$ & 1,53 & 2,74 & $-0,52$ \\
\hline & 4.08 & 4,7 & bnlg2162 & $-9,5 \mathrm{C}$ & 1,16 & 5,71 & $-10,95^{*}$ & 3,10 & $-0,42$ & 3,33 & $-0,23$ \\
\hline & 4.08 & 4,6 & umc1086 & $-6,98$ & $-0,78$ & $12,93 *$ & $-5,50 *$ & 5,67 & $2,46^{* *}$ & 1,61 & 0,36 \\
\hline & 4.08 & 11,5 & umc1051 & $-9,73$ & $-1,55$ & 3,81 & $-4,77 *$ & $5,05^{*}$ & $2,74 * * *$ & 1,95 & 0,09 \\
\hline & 4.09 & 15,6 & umc1989 & $-2,3 \mathrm{C}$ & $-2,07$ & 0,94 & $-1,43$ & $-1,66$ & $2,86^{*}$ & $-1,54$ & 0,05 \\
\hline & 4.09 & 0,6 & phi314704 & 0,75 & $-1,63$ & $-5,50$ & $-6,47 * * *$ & $-7,24 * * *$ & $-0,47$ & $-0,09$ & 0,29 \\
\hline & 4.11 & 0,2 & bnlg0589 & $2,8 \mathrm{C}$ & 0,64 & $-6,45$ & $-7,43 * * *$ & $-6,71$ **** & 0,27 & $0,8 \mathrm{C}$ & 0,64 \\
\hline & 4.10 & 0,2 & umc 1503 & 1,58 & $-1,92$ & $-4,20$ & $-6,12 * * *$ & $-6,75^{* * *}$ & 0,42 & 0,27 & 0,40 \\
\hline & 4.10 & 5,9 & umc1532 & 0,49 & $-2,85$ & $-3,45$ & $-5,39 * * *$ & $-6,07 * *$ & 0,97 & $0,3 \mathrm{C}$ & 0,60 \\
\hline & 4.10 & 6,3 & umc1109 & 8,02 & $-2,67$ & $-6,36$ & $-8,01 * *$ & $-9,69 * * * *$ & $-1,38$ & $-0,11$ & $-0,05$ \\
\hline & 4.11 & 6,2 & bnlg1337 & 6,78 & $-2,54$ & $-6,06$ & $-3,80$ & $-5,16 * *$ & $-2,60 * *$ & $-1,77$ & 0,41 \\
\hline & 4.11 & & umc1197 & $15,60 *$ & $-2,73$ & $-1,46$ & $-4,25^{*}$ & $-6,12 * *$ & $-4,49 * * *$ & $-0,94$ & 1,39 \\
\hline \multirow[t]{16}{*}{5} & 5.00 & 40,7 & bnlg1006 & $-6,39$ & $-1,72$ & $11,89 * * *$ & $-0,99$ & $-1,59 *$ & $-0,52$ & $-0,1 \mathrm{C}$ & $-0,19$ \\
\hline & 5.02 & 8,3 & umc1587 & $-22,82 * *$ & $-1,85$ & $15,42 *$ & 3,14 & 3,35 & $-0,47$ & $-0,12$ & 0,08 \\
\hline & $5.03-04$ & 45,3 & phi0113 & $-21,93^{*}$ & $-2,20$ & $19,68 * *$ & 3,61 & $5,14 *$ & $-1,43$ & $-1,45^{*}$ & 0,35 \\
\hline & 5.03 & 16,1 & bnlg 1879 & $-25,09 * *$ & $-5,02^{*}$ & $24,97 * *$ & 2,49 & $5,83^{*}$ & $-1,89 * *$ & $-1,78$ & 0,26 \\
\hline & 5.03 & 14,1 & umc 1056 & $-19,89 * *$ & 1,64 & $27,43 * *$ & $-3,87$ & $7,27^{*}$ & $-0,23$ & $-2,14$ & 1,10 \\
\hline & 5.03 & 9,7 & bnlg1902 & $-15,91$ & $-0,76$ & $26,82 * *$ & $-5,02$ & $9,54 * * *$ & $-0,68$ & $-0,36$ & 0,61 \\
\hline & 5.04 & 17,7 & dupssr10 & $-11,44$ & $4,60 *$ & $25,04 * *$ & $-4,91$ & $10,92 * * *$ & 1,00 & 1,22 & $-0,80$ \\
\hline & 5.04 & 3,8 & umc1221 & $-1,47$ & $-1,09$ & $19,90 * *$ & $-3,09 *$ & $8,61 * * *$ & $-0,59$ & 3,15 & $-1,88 * *$ \\
\hline & 5.05 & 23,5 & $\mathrm{mmc} 0081$ & $-6,12$ & 1,67 & $16,92 * *$ & $-5,48 * *$ & $5,65^{* *}$ & $-1,88$ & 1,96 & $-1,30 *$ \\
\hline & 5.06 & 2,1 & umc1019 & $16,70 * * *$ & $-1,65$ & 0,69 & $-2,95$ & $-4,86 * * *$ & $-2,17$ & 0,99 & $-0,71$ \\
\hline & 5.06 & 2,3 & mmc0481 & $17,39 * * *$ & $-2,62$ & 4,53 & $-1,47$ & $-3,03$ & $-2,25$ & 1,37 & $-0,76$ \\
\hline & $5.05-06$ & 61,6 & bnlg278 & $18,18 * *$ & $-2,26$ & $-0,45$ & $-1,93$ & $-3,30$ & $-2,16$ & 1,18 & $-1,01$ \\
\hline & 5.06 & 0,1 & umc 1680 & $19,11 * * *$ & $-3,12$ & 0,23 & $-1,79$ & $-3,14$ & $-1,36$ & 0,71 & $-0,54$ \\
\hline & 5.06 & 21,9 & umc1524 & $21,20 * * *$ & $-3,29$ & $-1,01$ & $-1,80$ & $-3,46$ & $-1,34$ & 1,39 & $-0,54$ \\
\hline & 5.07 & 32,3 & phi0128 & $19,79 *$ & $-7,63 * *$ & 0,68 & $-0,90$ & $-2,55$ & $1,75^{*}$ & 1,13 & 0,07 \\
\hline & 5.09 & & umc1153 & $-7,5 \mathrm{C}$ & $-1,54^{*}$ & $-2,46$ & $-3,58$ & $5,35^{* *}$ & 1,18 & $-1,86$ & $-0,25$ \\
\hline \multirow[t]{12}{*}{6} & 6.00 & 34,3 & phi0126 & 6,48 & 1,32 & $16,06 * * *$ & $-7,79 *$ & 0,94 & $-4,22 * *$ & 0,28 & 0,08 \\
\hline & 6.02 & 14,3 & bnlg 1371 & $-7,62$ & 4,43 & $18,51 *$ & $-2,95$ & 1,17 & 0,64 & 0,53 & 0,79 \\
\hline & 6.01 & 9,9 & phi0077 & $-6,47$ & 3,85 & $24,83 * *$ & $-1,60$ & $-0,70$ & 0,49 & 1,89 & 0,23 \\
\hline & 6.02 & 0,8 & umc1006 & $-4,15$ & $6,92 * *$ & $11,92 *$ & $-6,66^{*}$ & $-0,63$ & $-1,25$ & 1,01 & 0,30 \\
\hline & 6.02 & 13,1 & umc1257 & $-4,37$ & $7,75 * *$ & $12,69 *$ & $-6,58$ & $-1,31$ & $-1,68$ & 1,43 & 0,64 \\
\hline & 6.03 & 13,9 & umc1887 & $-3,19$ & 0,41 & $20,71 * * * *$ & $-0,01$ & $-2,69$ & 0,09 & $2,8 \mathrm{C} *$ & 0,51 \\
\hline & 6.04 & 18,9 & umc1614 & 6,35 & $-6,37^{*}$ & $16,58 *$ & 0,35 & $-8,36^{*}$ & 0,44 & 2,48 & 0,50 \\
\hline & 6.05 & 22,4 & nc0013 & $-11,16$ & $-7,12 * *$ & $12,59 *$ & 0,55 & $-4,97 *$ & $1,74^{*}$ & $-1,51$ & $-0,65$ \\
\hline & 6.06 & 21,2 & umc 1520 & $-5,45$ & $-3,34 *$ & 8,98 & $-0,33$ & $-12,12 * *$ & $-0,55$ & $2,93^{*}$ & 0,54 \\
\hline & 6.07 & 11,5 & bnlg 1759 & $-16,46^{*}$ & 2,35 & 0,50 & $-5,17 *$ & $-6,83^{* *}$ & $-2,53$ & $-0,63$ & $-0,01$ \\
\hline & 6.07 & 2,6 & umc 1653 & $-14,24 *$ & $-0,85$ & $-3,50$ & 0,66 & $-9,28^{* *}$ & $-0,31$ & $-0,29$ & $-0,81$ \\
\hline & 6.08 & & umc1127 & $-14,91^{*}$ & $-1,32$ & $-2,55$ & 1,49 & $-8,87 *$ & $-1,51$ & $-0,90$ & 0,15 \\
\hline
\end{tabular}


Tabela 10. Estimativas e significâncias dos coeficientes de regressão parciais (ấs) para os caracteres número de grãos por fileira (NGF) e número de fileiras por espiga (NFI).

\begin{tabular}{|c|c|c|c|c|c|c|c|c|c|c|c|}
\hline \multirow{2}{*}{$\mathrm{C}^{\mathrm{a}}$} & \multirow{2}{*}{ Bin } & \multirow{2}{*}{$\mathrm{cM}^{\mathrm{b}}$} & \multirow{2}{*}{ Marcador } & \multicolumn{4}{|c|}{$\mathrm{NGF}^{\mathrm{e}}$} & \multicolumn{4}{|c|}{$\mathrm{NFI}^{\mathrm{e}}$} \\
\hline & & & & $\hat{a}_{1}{ }^{c}$ & $\hat{a}_{2}$ & $\hat{a}_{3}$ & $\hat{a}_{4}$ & $\hat{a}_{1}$ & $\hat{a}_{2}$ & $\hat{a}_{3}$ & $\hat{a}_{4}$ \\
\hline \multirow[t]{9}{*}{$T$} & 7.00 & 34,5 & umc1426 & $20,09^{* * *}$ & 1,81 & $-1,28$ & $-4,12^{*}$ & $-1,19$ & $-0,20$ & $-1,93$ & $-0,21$ \\
\hline & 7.01 & 7,6 & umc1632 & $-5,2 \mathrm{C}$ & 0,85 & $25,69 * *$ & $-5,45 * *$ & $2,89 *$ & $-0,87$ & $-0,76$ & $-1,20 *$ \\
\hline & 7.01 & 0,1 & umc1409 & $-18,22 * *$ & $-1,82$ & $32,54 * * *$ & $-5,44 * *$ & $6,88^{* *}$ & $-0,34$ & $-2,39$ & $-1,98 *$ \\
\hline & 7.02 & 28,3 & bnlg1094 & $-18,76 * *$ & $-1,95$ & $31,49 * *$ & $-4,82 * *$ & $6,42 * *$ & $-0,11$ & $-1,86$ & $-1,90 *$ \\
\hline & 7.03 & 39,7 & bnlg0434 & $-17,81^{*}$ & 6,39 & $26,57 * *$ & 0,27 & $8,77 * *$ & $-2,78 * * *$ & $-0,02$ & 0,24 \\
\hline & 7.04 & 32,6 & dupssr13 & $-2,98$ & 3,34 & $12,26 *$ & 5,00 & $-0,86$ & 1,89 & $-2,71^{*}$ & $-2,40 *$ \\
\hline & 7.05 & 3,2 & umc1154 & 1,38 & 4,36 & $-12,19$ & $-7,20 * *$ & $-3,84$ & 0,10 & $-3,01$ & $-1,10$ \\
\hline & 7.05 & 6,7 & umc 1407 & $-11,07^{*}$ & 3,21 & $-4,36$ & $-2,44$ & 0,53 & 1,54 & $-2,71^{*}$ & $-0,36$ \\
\hline & 7.06 & & phi0116 & $-4,14$ & $6,36^{*}$ & $-4,46$ & $-0,24$ & 1,32 & 0,57 & $-2,91$ & $-0,20$ \\
\hline \multirow[t]{11}{*}{8} & 8.01 & 12,1 & umc1139 & 2,29 & $-4,64$ & $20,21 * *$ & 0,19 & $6,84^{*}$ & $2,05^{*}$ & 0,37 & 0,33 \\
\hline & 8.00 & 14,5 & phi420701 & $-0,04$ & 0,50 & $13,61 *$ & 1,60 & $8,86^{* *}$ & $1,72 *$ & 3,09 & $-0,37$ \\
\hline & 8.02 & 11,9 & phi0119 & $-0,93$ & $-1,08$ & $13,86^{*}$ & $-0,42$ & $12,74 * * *$ & $-1,08$ & 1,96 & $-0,21$ \\
\hline & 8.03 & 22,0 & umc1034 & $-5,44$ & $-3,82$ & $15,18 *$ & 0,09 & $10,89 * * *$ & $-0,53$ & 1,52 & $-0,27$ \\
\hline & 8.04 & 24,4 & bnlg 1863 & $-7,25$ & 2,56 & $23,00 *$ & $5,42 *$ & $5,47 * *$ & $-2,22 * *$ & 0,78 & 0,59 \\
\hline & 8.05 & 37,4 & bnlg1176 & $-2,08$ & $-2,97$ & 10,49 & $-2,19$ & $10,02 * * *$ & 1,37 & 1,18 & $1,71 * *$ \\
\hline & 8.06 & 12,5 & bnlg 1607 & $13,72 * *$ & $3,49 *$ & 9,11 & $-4,48$ & $-2,35$ & 1,68 & 2,27 & 0,37 \\
\hline & 8.07 & 8,9 & bnlg 1823 & $1,7 \mathrm{C}$ & $6,57 *$ & 6,58 & $-3,35$ & $2,33^{*}$ & $2,80^{*}$ & $1,24_{\circ}$ & 0,27 \\
\hline & 8.08 & 12,1 & umc1005 & $-6,33$ & $7,16 * *$ & $-1,73$ & $-2,68$ & $2,68^{*}$ & $-0,41$ & $2,01_{\circ}$ & $-0,28$ \\
\hline & 8.09 & 15,6 & dupssr14 & 3,12 & $-0,85$ & $-1,66$ & $-0,87$ & $-1,70$ & $1,43^{*}$ & 0,75 & $-0,66$ \\
\hline & 8.09 & & bnlg1131 & $6,5 \mathrm{C}$ & $-3,00$ & $-3,17$ & 2,84 & 2,42 & 0,01 & $0,7 \mathrm{C}$ & $-0,07$ \\
\hline \multirow[t]{10}{*}{9} & 9.02 & 2,4 & umc 1170 & $-3,51$ & $-1,79$ & 11,80 & $-6,22 *$ & $7,49 * * *$ & $-4,34 * *$ & $-2,31$ & 0,77 \\
\hline & 9.02 & 11,8 & dupssr06 & $-1,25$ & $-2,14$ & $13,64 *$ & $-6,13^{*}$ & $7,06 * * *$ & $-4,85^{*} *$ & $-1,96$ & $1,16^{*}$ \\
\hline & 9.02 & 4,7 & bnlg1401 & $-0,33$ & $-0,78$ & $18,68 * *$ & $-6,43^{*}$ & $4,38^{*}$ & $-3,78 * *$ & $-0,11$ & 0,18 \\
\hline & 9.02 & 14,0 & umc1893 & 2,14 & $-5,81$ & $14,05 *$ & $-6,96 * *$ & 2,31 & $-2,40 *$ & $-0,15$ & $-0,11$ \\
\hline & 9.03 & 12,3 & bnlg0430 & $-1,05$ & $-4,95$ & 9,93 & $-6,23^{*}$ & $-1,21$ & $-3,10 * *$ & 2,47 & 0,51 \\
\hline & 9.04 & 5,6 & umc1107 & $-1,14$ & $-1,09$ & 11,06 & $-1,81$ & $-1,04$ & $-2,49 * *$ & 0,32 & $-0,46$ \\
\hline & 9.05 & 34,1 & bnlg 1012 & $-6,09$ & $-0,24$ & 8,54 & $-2,12$ & 4,60 & $-0,01$ & $-1,26$ & $-0,83$ \\
\hline & 9.06 & 13,8 & umc1733 & 3,37 & 2,18 & 2,84 & 2,16 & $-3,28$ & $-2,61$ & $-1,89$ & $1,73^{*}$ \\
\hline & $9.07-08$ & 87,8 & bnlg0619 & 0,68 & 2,04 & 3,00 & $-1,23$ & $-0,01$ & $-0,56$ & $-3,64^{*}$ & $-0,32$ \\
\hline & 9.07 & & bnlg0128 & 1,78 & $4,48^{*}$ & 2,66 & $-4,54 *$ & $-2,25$ & $-0,65$ & $-0,92$ & 0,69 \\
\hline \multirow[t]{12}{*}{10} & 10.00 & 9,8 & phi0117 & $-4,34$ & 1,87 & $15,61 *$ & 5,25 & 2,67 & $3,33^{*}$ & 0,87 & 0,69 \\
\hline & 10.01 & 6,3 & umc1319 & $-4,19$ & $-1,48$ & $23,32 * *$ & $4,97 * *$ & $8,92 * * *$ & $4,40 * *$ & 0,39 & 0,40 \\
\hline & 10.02 & 40,7 & bnlg1451 & $-13,23$ & $-4,98$ & $15,28 *$ & 0,11 & $7,09 * * *$ & $3,31 * *$ & $2,32 *$ & 0,01 \\
\hline & 10.03 & 7,3 & bnlg0640 & $-10,81^{*}$ & $-11,45 * * *$ & $16,61 *$ & $-0,33$ & $22,56 * * * * *$ & $2,58 * *$ & 2,19 & $-0,54$ \\
\hline & 10.04 & 27,0 & bnlg1526 & $-6,93$ & $-3,15$ & $16,60 *$ & $5,49 * * *$ & $21,98 * * * * *$ & $1,30 * *$ & 2,55 & $-0,26$ \\
\hline & 10.05 & 7,0 & umc1930 & $-15,77$ & $-1,12$ & $27,47 * * *$ & $-1,30$ & $12,35 * * *$ & $-0,78$ & 2,56 & $-0,69$ \\
\hline & 10.05 & 12,1 & umc1506 & $-12,95$ & $-2,62$ & $34,18 * * *$ & $-1,94$ & 5,08 & $-0,22$ & 1,96 & $-0,15$ \\
\hline & 10.07 & 0,2 & umc1196 & $-45,00 * * *$ & 5,31 & $53,68 * * * *$ & $6,52 *$ & 1,85 & $1,52 *$ & 0,04 & 1,03 \\
\hline & 10.07 & 0,1 & umc1038 & $-46,38 * * *$ & 6,23 & $57,95 * * * *$ & 5,85 & $-0,71$ & $2,50 * *$ & $-0,41$ & 1,13 \\
\hline & 10.07 & 0,1 & umc2021 & $-40,74 * *$ & 4,50 & $51,62 * * * *$ & 5,70 & 0,07 & $1,93^{* *}$ & 1,24 & 1,01 \\
\hline & 10.07 & 1,4 & umcl569 & $-36,32 * *$ & 3,71 & $54,60 * * * *$ & $9,47 *$ & $5,2 \mathrm{C}^{*}$ & $2,07 * *$ & 0,61 & 1,56 \\
\hline & 10.07 & & bnlg1839 & $-35,19 * *$ & 0,16 & $50,56 * * *$ & 4,02 & $-0,66$ & $3,52 * *$ & 0,99 & $-0,73$ \\
\hline
\end{tabular}

${ }^{a}$ número do cromossomo; ${ }^{b}$ distância em centiMorgan $(\mathrm{cM})$ entre locos adjacentes; ${ }^{\mathrm{c}}$ Níveis de significância dos efeitos dos contrastes: * $\mathrm{B} 0,05$; ** $\mathrm{P} \leq 0,01$; *** $\mathrm{P} \leq 0,001$; **** $\mathrm{P} \leq 0,0001 \mathrm{e} * * * * *$ $\mathrm{P} \leq 0,00001$; níveis de significância das interações contrastes por ambientes: o $\mathrm{P} \leq 0,05$; oo $\mathrm{P} \leq 0,01$; ${ }^{\mathrm{e}}$ estimativas dos efeitos multiplicadas por $10^{-2}$. 
Tabela 11. Estimativas e significâncias dos coeficientes de regressão parciais ( $\left.\hat{a}^{\prime} s\right)$ para os caracteres número de ramificações do pendão (RP) e peso de 500 grãos (P500).

\begin{tabular}{|c|c|c|c|c|c|c|c|c|c|c|c|}
\hline \multirow{2}{*}{$\mathrm{C}^{\mathrm{a}}$} & \multirow{2}{*}{ Bin } & \multirow{2}{*}{\multicolumn{2}{|c|}{$\mathrm{cM}^{\mathrm{b}}$ Marcador }} & \multicolumn{4}{|c|}{ P500 (gramas) } & \multicolumn{4}{|c|}{$\mathrm{RP}^{\mathrm{e}}$} \\
\hline & & & & $\hat{a}_{1}^{c}$ & $\hat{a}_{2}$ & $\hat{a}_{3}$ & $\hat{a}_{4}$ & $\hat{a}_{1}$ & $\hat{a}_{2}$ & $\hat{a}_{3}$ & $\hat{a}_{4}$ \\
\hline \multirow[t]{19}{*}{1} & 1.01 & 10,7 & umc ITT7 & $-0,71^{*}$ & 0,03 & $1,20^{*}$ & 0,22 & $-5,12$ & $-3,1 \mathrm{C}$ & 0,31 & $4,22 *$ \\
\hline & 1.01 & 0,9 & bnlg1014 & $-0,25$ & 0,09 & $1,02 *$ & $0,20 * *$ & $-11,83 *$ & 2,06 & 3,21 & $3,27 * *$ \\
\hline & 1.00 & 19,8 & umc1106 & 0,07 & 0,21 & $1,18 * *$ & 0,12 & $-12,93 *$ & 0,76 & 6,54 & $3,93 * * * * *$ \\
\hline & 1.02 & 11,4 & bnlg1627 & $-1,13 * *$ & $0,26^{*}$ & $1,07 * *$ & 0,00 & 1,26 & 2,08 & $11,10 * * *$ & 2,54 \\
\hline & 1.02 & 5,7 & bnlg1083 & $-0,63$ & $-0,11$ & $0,71 *$ & 0,04 & 9,03 & 3,78 & $14,53 * *$ & 1,88 \\
\hline & 1.03 & 9,9 & umc 1073 & $-0,68$ & 0,14 & $0,96 * *$ & 0,13 & 3,16 & 4,77 & $13,82 * *$ & 0,78 \\
\hline & 1.03 & 8,7 & umc1021 & $-1,77 * *$ & 0,10 & $0,97 *$ & $-0,07$ & 2,15 & 5,67 & 9,23 & 1,02 \\
\hline & 1.04 & 21,9 & bnlg 2238 & $-1,09 *$ & $0,30 * *$ & $0,77 *$ & $-0,05$ & $12,65^{*}$ & $-5,53^{*}$ & $15,05 * *$ & $-1,93$ \\
\hline & 1.05 & 13,1 & umc2025 & $-0,48$ & $0,62 *$ & $1,35 *$ & $-0,13$ & $-17,36 *$ & $-0,59$ & $22,07 * * *$ & $-4,01 *$ \\
\hline & 1.05 & 10,7 & umc1601 & $-0,79_{0}$ & 0,34 & $1,29 *$ & $-0,05$ & $-0,75$ & $3,32^{*}$ & $19,53 * *$ & $-4,05^{*}$ \\
\hline & 1.06 & 5,7 & umc 1508 & $-1,08 *$ & 0,41 & $1,07 *$ & 0,02 & $-11,35$ & $-0,13$ & 10,39 & $-6,43 * *$ \\
\hline & 1.06 & 6,8 & bnlg1598 & $-1,23 * *$ & 0,16 & 0,96 & 0,14 & $-19,40$ & 3,15 & 10,58 & $-1,76$ \\
\hline & 1.06 & 25,6 & umc1035 & $-2,29 * *$ & $-0,24$ & $0,84 *$ & 0,15 & $-14,95$ & $-2,32$ & $12,99 *$ & 0,10 \\
\hline & 1.07 & 15,9 & bnlg0615 & $-0,59$ & $-0,09$ & 0,43 & 0,03 & 4,84 & 2,07 & 2,90 & $-2,52$ \\
\hline & 1.10 & 24,1 & umc1431 & $-2,01 * *$ & $-0,02$ & 0,01 & $-0,02$ & $22,82 * *$ & 3,62 & 0,03 & $-0,26$ \\
\hline & 1.08 & 24,2 & phi0037 & $-1,20 *$ & $-0,05$ & 0,39 & 0,20 & $12,82 *$ & $-0,32$ & $-2,34$ & $-0,03$ \\
\hline & 1.11 & 11,6 & phi0120 & $-1,48^{*}$ & $-0,06$ & 0,18 & $-0,16$ & 2,20 & $6,44^{*}$ & 2,58 & $-1,23$ \\
\hline & 1.11 & 17,6 & umc 1630 & $-1,37 * *$ & $-0,29$ & 0,12 & 0,11 & $16,08 *$ & $7,47 *$ & 3,48 & 2,95 \\
\hline & 1.12 & & umc 1605 & $-0,25$ & $-0,15$ & $-0,07$ & 0,24 & $26,71 * *$ & $6,4 \mathrm{Y} *$ & 2,23 & 1,58 \\
\hline \multirow[t]{19}{*}{2} & 2.01 & 4,6 & umc 1165 & $-0,55$ & 0,05 & $0,59 *$ & $-0,05$ & $40,34 * * *$ & 0,65 & 4,72 & 2,00 \\
\hline & 2.01 & 1,3 & bnlg 1338 & $-0,90 *$ & 0,02 & $0,60 *$ & $-0,02$ & $42,35 * * *$ & 1,67 & $9,95 *$ & $-1,84$ \\
\hline & 2.01 & 1,5 & umc 1227 & $-0,43$ & 0,02 & 0,47 & $-0,07$ & $47,42 * * *$ & 0,04 & 4,83 & $-0,71$ \\
\hline & 2.02 & 2,8 & bnlg1017 & $-0,62^{*}$ & $-0,09$ & $0,67 *$ & $-0,09$ & $44,78 * * *$ & 0,03 & 8,11 & $-1,98$ \\
\hline & 2.02 & 12,9 & umc 1265 & $-0,80 *$ & $-0,08$ & $0,66^{*}$ & $-0,16$ & $41,74 * * *$ & 1,04 & $8,75^{*}$ & $-2,13$ \\
\hline & 2.02 & 8,6 & umc1934 & $-0,87^{*}$ & $-0,05$ & 0,66 & $-0,06$ & $49,75 * * *$ & 2,06 & 4,45 & 0,01 \\
\hline & 2.02 & 4,0 & bnlg0125 & $-0,92 *$ & 0,11 & 0,49 & $-0,17$ & $70,30 * * * *$ & $-3,3 \mathrm{C} *$ & 6,05 & $-0,22$ \\
\hline & 2.03 & 0,9 & umc 1845 & $-0,48$ & 0,10 & $0,70 *$ & $-0,24$ & $64,79 * * * *$ & $-4,13^{*}$ & 8,64 & $-2,95$ \\
\hline & 2.03 & 2,5 & umc 1776 & $-0,56$ & 0,05 & $0,85 * *$ & $-0,26$ & 75,46 ****** & $-7,92 * *$ & $7,77 *$ & $-2,15$ \\
\hline & 2.03 & 7,1 & bnlg2248 & $-0,53$ & $-0,21$ & $0,97 * *$ & $-0,21$ & $77,90 * * * *$ & $-7,84 * *$ & 4,09 & $-0,83$ \\
\hline & 2.03 & 32,2 & bnlg0381 & $-0,02$ & $-0,30$ & 0,14 & $-0,04$ & $63,35 * * * *$ & $-5,45^{*}$ & 9,52 & $-1,51$ \\
\hline & 2.04 & 10,1 & bnlg0166 & $-1,13$ & 0,28 & $-0,07$ & 0,28 & $19,27 * *$ & 1,32 & 7,03 & $-2,19$ \\
\hline & 2.05 & 19,5 & dupssr21 & $-0,62 *$ & 0,11 & 0,10 & $0,51 * *$ & 11,02 & $-2,48$ & $9,59 *$ & $6,23 * * *$ \\
\hline & 2.06 & 78,3 & bnlg1396 & $-0,80$ & 0,20 & $-0,23$ & $0,33 *$ & $26,69 * *$ & $-0,78$ & 2,60 & 1,53 \\
\hline & 2.07 & 6,3 & umc 1560 & $-1,27 *$ & $-0,05$ & $-0,27$ & $-0,15^{*}$ & $14,42 * *$ & 3,83 & 7,08 & $-3,18$ \\
\hline & 2.08 & 6,5 & umc1464 & $-1,63 * * *$ & $0,15^{*}$ & $-0,31$ & $-0,03$ & $-2,23$ & $-2,84$ & $10,72 *$ & $-0,11$ \\
\hline & 2.08 & 6,9 & umc 1633 & $-1,52 * *$ & 0,07 & $-0,30$ & $-0,14^{*}$ & $-3,59$ & $-3,96$ & $11,17 *$ & $-0,40$ \\
\hline & 2.09 & 4,9 & umc 1230 & $-1,92 *$ & $-0,16$ & $-0,42$ & $-0,09$ & $-3,35$ & 1,45 & $14,74 * *$ & $3,64 *$ \\
\hline & 2.09 & & bnlg 1520 & $-2,02 * *$ & 0,00 & $-0,18$ & $-0,15$ & 0,75 & 2,27 & $11,61 *$ & 1,27 \\
\hline \multirow[t]{13}{*}{3} & 3.01 & 17,4 & umc1394 & $-0,90$ & 0,29 。 & $-0,09$ & $-0,09$ & $-10,72 *$ & $7,5 y * * *$ & $-2,42$ & $-3,14^{*}$ \\
\hline & 3.03 & 27,7 & bnlg1144 & $-1,08 *$ & 0,28 & $0,63 *$ & $-0,09$ & $-8,55$ & $6,07 * *$ & $6,23 *$ & $-2,36$ \\
\hline & 3.04 & 7,8 & bnlg 1452 & $-1,59 * * *$ & 0,22 & $1,04 *$ & $-0,06$ & $-5,76$ & $3,84 *$ & $14,24 * *$ & $-4,82$ \\
\hline & 3.04 & 12,1 & bnlg602 & $-0,79 * *$ & 0,33 & $1,20 * *$ & $-0,13$ & $-10,26$ & 0,14 & $12,63 * *$ & 1,38 \\
\hline & 3.05 & 1,8 & bnlg0420 & $-0,80 * *$ & 0,15 & $0,97 * *$ & 0,00 & $-27,88 * *$ & $-3,64$ & 6,87 & $-1,06$ \\
\hline & 3.05 & 34,1 & $\mathrm{mmc} 0022$ & $-0,90 * *$ & $-0,11$ & $1,10 * *$ & 0,04 & $-25,92 * *$ & $-1,43$ & $9,53^{*}$ & 0,42 \\
\hline & 3.06 & 28,6 & bnlg 1798 & $-0,50_{0}$ & $-0,69 *$ & $0,95 *$ & 0,31 & $-10,20$ & $9,4 C^{*} *$ & 12,71 & 2,46 \\
\hline & 3.07 & 3,3 & umc1690 & 0,66 & $-0,24$ & $0,88 *$ & $-0,25$ & 3,16 & $-0,28$ & $11,00 *$ & 0,87 \\
\hline & 3.07 & 16,0 & umc1659 & $1,81 * 0$ & 0,03 & 0,57 & $-0,24$ & 4,76 & $-1,02$ & $10,15 *$ & 1,15 \\
\hline & 3.08 & 14,1 & umc 1320 & $1,95^{*}$ & 0,23 & 0,92 & 0,08 & 1,05 & $-1,37$ & 5,53 & 2,12 \\
\hline & 3.09 & 2,9 & bnlg 1536 & $1,74 * *$ & 0,37 & 0,60 & 0,12 & 5,83 & $6,26 * * *$ & 4,46 & 0,47 \\
\hline & 3.09 & 26,7 & bnlg1754 & $1,86 * *$ & 0,13 & 0,74 & $-0,04$ & $-0,57$ & $8,64 * * *$ & $7,26 * *$ & $-3,27^{*}$ \\
\hline & 3.10 & & bnlg 1098 & $0,85^{*}$ & 0,13 & 0,05 & $-0,14$ & $13,56 *$ & 0,84 & $-6,14$ & $-0,38$ \\
\hline
\end{tabular}


Tabela 11. Estimativas e significâncias dos coeficientes de regressão parciais ( $\left.\hat{a}^{\prime} s\right)$ para os caracteres número de ramificações do pendão (RP) e peso de 500 grãos (P500).

\begin{tabular}{|c|c|c|c|c|c|c|c|c|c|c|}
\hline \multirow{2}{*}{$\mathrm{C}^{\mathrm{a}}$} & \multirow{2}{*}{ Bin } & \multirow{2}{*}{$\mathrm{cM}^{\mathrm{b}}$ Marcador } & \multicolumn{4}{|c|}{ P500 (gramas) } & \multicolumn{4}{|c|}{$\mathrm{RP}^{\mathrm{e}}$} \\
\hline & & & $\hat{a}_{1}^{c}$ & $\hat{a}_{2}$ & $\hat{a}_{3}$ & $\hat{a}_{4}$ & $\hat{a}_{1}$ & $\hat{a}_{2}$ & $\hat{a}_{3}$ & $\hat{a}_{4}$ \\
\hline \multirow[t]{19}{*}{4} & 4.01 & 55,7 umcl2 276 & $-0,44$ & 0,46 & 0,29 & $0,17^{*}$ & 9,72 & 2,66 & 0,17 & $-3,48^{*}$ \\
\hline & 4.04 & 3,4 umc 1652 & $-0,49$ & $0,31 *$ & $-0,24$ & $-0,01$ & $-2,82$ & $-2,38$ & 7,33 & 3,32 \\
\hline & 4.05 & 0,1 phi0026 & $-0,51$ & $0,42 *$ & $-0,29$ & $-0,08$ & $-3,28$ & 1,39 & 6,25 & 0,49 \\
\hline & 4.05 & 1,7 umc1088 & $-0,48$ & $0,44 * *$ & $-0,18$ & 0,01 & $-1,04$ & $-1,52$ & 5,42 & 2,16 \\
\hline & 4.06 & 35,6 bnlg 0252 & $-0,56$ & $0,33^{*}$ & $-0,28$ & $-0,10$ & 0,09 & 0,93 & 5,07 & 0,44 \\
\hline & 4.07 & 5,1 bnlg 2291 & $-0,59$ & $-0,16$ & 0,49 & $-0,06$ & $-20,97 * *$ & $-0,22$ & $9,64 *$ & $-3,26$ \\
\hline & 4.07 & 18,0 dupssr34 & $-0,23$ & 0,03 & 0,35 & $-0,23 * *$ & $-23,16 * *$ & $-1,69$ & 6,19 & $-1,21$ \\
\hline & 4.08 & $2,0 \quad$ bnlg2244 & $-1,20^{*}$ & $-0,31$ & 0,52 & $-0,14 *$ & $-26,44 * * *$ & $-3,23$ & 5,36 & $-4,44$ \\
\hline & 4.08 & $4,7 \quad$ bnlg 2162 & $-0,98$ & $-0,14$ & 0,26 & $-0,28 * *$ & $-32,69 * * * *$ & $-7,58 * * *$ & $-0,02$ & $-7,48 * *$ \\
\hline & 4.08 & 4,6 umc1086 & $-0,91$ & $-0,65$ o & $0,81 * *$ & $-0,09$ & $-42,19 * * * *$ & $-9,94 * * *$ & 4,60 & $-1,79$ \\
\hline & 4.08 & 11,5 umc 1051 & $-1,05^{*}$ & $-0,38$ & $0,77 *$ & $-0,06$ & $-40,83 * * * *$ & $-6,18^{*}$ & 3,24 & 0,06 \\
\hline & 4.09 & 15,6 umc1989 & $-0,66$ & $-0,45 * *$ & $0,80 *$ & 0,01 & $-40,89 * * *$ & $-7,82^{*}$ & $-0,65$ & 1,22 \\
\hline & 4.09 & 0,6 phi314704 & 0,02 & $-0,22 *$ & 0,12 & $-0,18$ & $-24,95 * *$ & $-8,06 * * *$ & $-3,44$ & $-1,06$ \\
\hline & 4.11 & 0,2 bnlg0589 & 0,41 & $-0,23^{*}$ & $-0,07$ & $-0,21$ & $-17,47 * *$ & $-4,86 * * * *$ & $-6,33$ & $-1,32$ \\
\hline & 4.10 & 0,2 umc1503 & 0,00 & $-0,32 * *$ & 0,15 & $-0,14$ & $-23,67 * *$ & $-5,37 * * *$ & $-2,51$ & $-0,30$ \\
\hline & 4.10 & 5,9 umc 1532 & 0,07 & $-0,26^{*}$ & 0,12 & $-0,14$ & $-22,06 * *$ & $-5,2 \mathrm{C} * * *$ & $-1,44$ & $-0,18$ \\
\hline & 4.10 & 6,3 umc1109 & 0,23 & $-0,39 * *$ & 0,05 & $-0,25$ & $-13,62 *$ & 2,07 & $-4,89$ & $-4,05$ \\
\hline & 4.11 & 6,2 bnlg 1337 & $-0,21$ & $-0,15$ & 0,17 & $-0,11$ & $-14,46 * *$ & $3,98 *$ & $-0,89$ & $-2,37$ \\
\hline & 4.11 & umc1197 & 0,07 & 0,26 & $-0,07$ & $-0,24$ & $-12,63 * *$ & 4,46 & $-1,16$ & $-2,34$ \\
\hline \multirow[t]{16}{*}{5} & 5.00 & 40,7 bnlg 1006 & $0,82 *$ & $-0,26^{*}$ & $0,66 * *$ & $-0,10$ & $-20,82 *$ & $-3,11$ & 8,83 & 1,91 \\
\hline & 5.02 & 8,3 umc1587 & 0,89 & $-0,21$ & $0,64 * *$ & $-0,12$ & $-13,09$ & $-8,78 * * *$ & 4,23 & 0,06 \\
\hline & $5.03-$ & 5,3 phi0113 & 0,63 & $-0,02$ & 0,61 & 0,07 & $-8,56$ & $-2,72 * *$ & 6,99 & 0,31 \\
\hline & 5.03 & 16,1 bnlg 1879 & 0,84 & 0,00 & $0,54 *$ & $-0,04$ & $-10,55$ & $-2,52$ & 11,68 & 2,31 \\
\hline & 5.03 & 14,1 umc1056 & $1,44 * *$ & 0,07 & $0,96 *$ & $-0,11$ & $-15,43 *$ & 4,28 & 9,99 & $-2,01$ \\
\hline & 5.03 & 9,7 bnlg1902 & $1,59 * *$ & $0,37 * *$ & $1,03 * *$ & $-0,19$ & $-23,71 * * *$ & 5,52 & $18,70 * *$ & $-1,86$ \\
\hline & 5.04 & 17,7 dupssr10 & $1,03^{*}$ & 0,21 & $1,20 * *$ & $-0,28$ & $-14,73 * *$ & 9,04 & $14,46^{*}$ & $-4,50$ \\
\hline & 5.04 & 3,8 umc1221 & $-0,46$ & $-0,02$ & $0,61 *$ & $-0,21$ & $-22,62 * *$ & 3,21 & $22,81 * *$ & $-1,69$ \\
\hline & 5.05 & $23,5 \mathrm{mmc} 0081$ & $-0,34$ & $0,20 *$ & $0,63 *$ & $-0,39$ & $-31,77 * *$ & $-3,17$ & $18,86^{* *}$ & $-1,86$ \\
\hline & 5.06 & 2,1 umc1019 & $-0,17 \mathrm{o}$ 。 & 0,02 & $-0,11$ & $-0,11$ & $-40,38 * * * *$ & $-9,05 * * *$ & $11,44 *$ & 1,72 \\
\hline & 5.06 & $2,3 \mathrm{mmc} 0481$ & $-0,40_{0}$ o & 0,04 & 0,09 & $-0,05$ & $-36,88 * * *$ & $-9,18^{* *}$ & $14,76 * *$ & 0,54 \\
\hline & $5.05-$ & $1,6 \quad$ bnlg 278 & $-0,20_{\mathrm{o}} \mathrm{o}$ & $-0,04$ & $-0,09$ & $-0,08$ & $-27,44 * * *$ & $-8,66^{*}$ & $12,92 * *$ & 0,32 \\
\hline & 5.06 & 0,1 umc 1680 & $-0,22_{0}$ o & $-0,06$ & $-0,13$ & $-0,07$ & $-27,07 * * *$ & $-7,46 * *$ & $12,65 * *$ & 0,92 \\
\hline & 5.06 & 21,9 umc 1524 & $-0,21_{o}$ o & $-0,06$ & $-0,04$ & $-0,07$ & $-27,87 * * *$ & $-7,2 C^{* *}$ & $11,86 *$ & 0,79 \\
\hline & 5.07 & 32,3 phi0128 & 0,10 & $-0,37 *$ & $-0,04$ & 0,04 & $-18,78^{*}$ & $-1,75$ & $10,21 *$ & 1,41 \\
\hline & 5.09 & umc 1153 & 0,19 & 0,17 & $-0,18$ & $-0,14$ & $22,76 * *$ & 2,98 & $-5,61$ & 2,89 \\
\hline \multirow[t]{12}{*}{6} & 6.00 & 34,3 phi0126 & $-0,25$ & $0,31 *$ & 0,07 & $-0,32 * *$ & 4,95 & $-0,35$ & $-0,75$ & $-2,05$ \\
\hline & 6.02 & 14,3 bnlg 1371 & $-0,74$ & $-0,23$ & 0,21 & $-0,01$ & $-11,51 * *$ & $-16,15 * * * *$ & $-9,73 * *$ & $-0,04$ \\
\hline & 6.01 & 9,9 phi0077 & $-0,92$ & 0,04 & 0,67 & 0,01 & $-11,75$ & $-6,45$ & $-5,96$ & 2,36 \\
\hline & 6.02 & 0,8 umc1006 & $-0,56$ & $-0,21$ & 0,05 & $-0,09$ & $-3,74$ & $-11,0 \leq * *$ & $-8,41$ & 0,45 \\
\hline & 6.02 & 13,1 umc1257 & $-0,79$ & $-0,18$ & $-0,06$ & $-0,07$ & $-7,71$ & $-12,13 * *$ & $-7,24$ & 0,23 \\
\hline & 6.03 & 13,9 umc1887 & $-0,30$ & $-0,16$ & 0,20 & 0,03 & $-11,78$ & $-2,02$ & $-0,05$ & $-1,00$ \\
\hline & 6.04 & 18,9 umc1614 & $1,00 *$ & 0,01 & 0,56 & 0,02 & $-10,15 * *$ & $8,39 * *$ & 10,64 & 1,21 \\
\hline & 6.05 & 22,4 nc0013 & $1,30 *$ & $-0,11$ & 0,25 & $-0,11$ & $-2,62$ & $4,67^{*}$ & $6,21^{*}$ & 0,73 \\
\hline & 6.06 & 21,2 umc 1520 & $0,99 *$ & $-0,31$ & 0,43 & $-0,01$ & $-2,73$ & $-11,14 * *$ & 2,76 & $-0,06$ \\
\hline & 6.07 & 11,5 bnlg 1759 & $0,32 *$ & $-0,48 *$ & $0,39 *$ & $-0,19 *$ & $-12,72 *$ & $-13,13 * *$ & 0,68 & $-5,00 * *$ \\
\hline & 6.07 & 2,6 umc1653 & 0,30 & $-0,67 * * *$ & $0,42 *$ & 0,13 & $-5,12$ & $-6,69 * *$ & 0,94 & $-2,50$ \\
\hline & 6.08 & umc 1127 & 0,26 & $-0,60 * *$ & 0,19 & 0,10 & $-10,05 *$ & $-7,25^{*}$ & $-2,48$ & $-2,32$ \\
\hline
\end{tabular}


Tabela 11. Estimativas e significâncias dos coeficientes de regressão parciais (âs's) para os caracteres número de ramificações do pendão (RP) e peso de 500 grãos (P500).

\begin{tabular}{|c|c|c|c|c|c|c|c|c|c|c|}
\hline \multirow{2}{*}{$\mathrm{C}^{\mathrm{a}}$} & \multirow{2}{*}{\multicolumn{2}{|c|}{ Bin $\mathrm{cM}^{\mathrm{b}}$ Marcador }} & \multicolumn{4}{|c|}{ P500 (gramas) } & \multicolumn{4}{|c|}{$\mathrm{RP}^{\mathrm{e}}$} \\
\hline & & & $\hat{a}_{1}^{c}$ & $\hat{a}_{2}$ & $\hat{a}_{3}$ & $\hat{a}_{4}$ & $\hat{a}_{1}$ & $\hat{a}_{2}$ & $\hat{a}_{3}$ & $\hat{a}_{4}$ \\
\hline \multirow{9}{*}{7} & $7.0034,5$ & umc 1426 & $-0,41$ & $-0,06$ & 0,10 & $0,32 \%$ & $-17,28 \%$ & 0,79 & 7,16 & $-2,65$ \\
\hline & $7.01 \quad 7,6$ & umc1632 & $-0,75$ & $-0,14$ & $0,89 *$ & $-0,14$ & $-13,70$ & 0,82 & $19,70 * * *$ & $-4,54^{*}$ \\
\hline & $7.01 \quad 0,1$ & umc1409 & $-0,96^{*}$ & $-0,21$ & $1,03 * *$ & $-0,31 *$ & $-4,34$ & 2,22 & $22,43 * * *$ & $-6,57 * *$ \\
\hline & $7.0228,3$ & bnlg1094 & $-0,71$ & $-0,27 *$ & $1,09 * *$ & $-0,31 *$ & $-2,66$ & 1,94 & $22,32 * * * *$ & $-6,87 * *$ \\
\hline & $\begin{array}{ll}7.03 & 39,7\end{array}$ & bnlg0434 & $-0,87 *$ & $-0,07$ & $1,30 * * *$ & $-0,08$ & $22,92 * * *$ & $-1,32$ & $13,23 * *$ & $-1,13$ \\
\hline & $7.04 \quad 32,6$ & dupssr13 & 0,19 & 0,16 & 0,52 & 0,03 & $12,40 *$ & $4,13^{* *}$ & $10,14^{*}$ & $-3,62$ \\
\hline & $7.05 \quad 3,2$ & umc1154 & $1,55 * *$ & 0,24 & 0,19 & 0,06 & $-3,97$ & $2,7 \mathrm{C}$ & $-1,10$ & $-3,16^{*}$ \\
\hline & $7.05 \quad 6,7$ & umc 1407 & $1,04 *$ & 0,20 & 0,25 & 0,22 & $-2,32$ & $3,85^{*}$ & 1,59 & 1,37 \\
\hline & 7.06 & phi0116 & $0,62 * * *$ & 0,01 & $-0,16$ & 0,14 & $-7,66^{*}$ & 3,37 & 2,68 & 1,52 \\
\hline \multirow[t]{11}{*}{8} & $8.01 \quad 12,1$ & umc1139 & $-0,92_{0}$ & $-0,14$ & $0,83 *$ & 0,27 & $22,02 *$ & $1,69 *$ & $-2,09$ & 3,14 \\
\hline & $8.0014,51$ & phi420701 & $-0,61$ o o & $-0,32$ & $1,19 *$ & 0,06 & $26,83 * *$ & $-9,12^{* *}$ & $-0,14$ & 0,93 \\
\hline & $8.0211,9$ & phi0119 & $-0,27$ o & $-0,12$ & $1,45 * *$ & $-0,05$ & $27,98 * *$ & 0,05 & 9,76 & $5,08 *$ \\
\hline & $8.0322,0$ & umc1034 & $-0,01$ & 0,03 & $0,86 *$ & $-0,24$ & $21,57 * * *$ & $-0,53$ & $11,01 *$ & $3,50 *$ \\
\hline & $8.04 \quad 24,4$ & bnlg 1863 & $0,11_{0}$ & 0,29 & $0,66 *$ & $-0,12$ & $11,24 *$ & $-2,91$ & 6,13 & 4,08 \\
\hline & $8.05 \quad 37,4$ & bnlg1176 & 0,21 & $-0,09$ & $1,13^{*}$ & $-0,24 * *$ & $16,39 *$ & 1,26 & $8,47^{*}$ & 2,50 \\
\hline & $8.06 \quad 12,5$ & bnlg 1607 & 0,39 & $-0,59 *$ & 0,45 & $-0,11$ & 5,58 & $-0,12$ & $7,68^{*}$ & 1,84 \\
\hline & $8.07 \quad 8,9$ & bnlg1823 & 0,56 & $-0,59 * *$ & $0,83 *$ & $-0,01$ & $18,43 *$ & 2,13 & $6,97 *$ & $-0,05$ \\
\hline & $8.08 \quad 12,1$ & umc 1005 & 0,47 & $-0,17$ & 0,59 & $-0,02$ & $21,44 *$ & $-1,53$ & $-0,45$ & 1,88 \\
\hline & $8.0915,6$ & dupssr14 & $0,92 *$ & 0,16 & 0,25 & 0,08 & $32,11 * *$ & 2,66 & $-3,53$ & 4,01 \\
\hline & 8.09 & bnlg1131 & 0,11 & $-0,03$ & $-0,41 *$ & 0,16 & $30,66 * *$ & $-4,02$ & 2,88 & 4,09 \\
\hline \multirow[t]{10}{*}{9} & $9.02 \quad 2,4$ & umc 1170 & $-1,10$ & $0,39 * * *$ & $0,75 * *$ & $-0,18$ & $19,46 * *$ & $-11,07 * *$ & $-4,20$ & $-4,65 * *$ \\
\hline & $9.0211,8$ & dupssr06 & $-1,15$ & $0,55 * *$ & $0,62 * *$ & $-0,07$ & $12,81 *$ & $-8,87 *$ & $-6,23$ & $-4,96^{*}$ \\
\hline & $9.02 \quad 4,7$ & bnlg1401 & $-1,28^{*}$ & $0,44 * * *$ & $0,84 * *$ & $-0,15$ & $22,68 * *$ & $-4,26^{*}$ & $-4,32$ & $-4,04 * *$ \\
\hline & $9.0214,0$ & umc1893 & $-1,05$ & $0,39 *$ & $0,89 * *$ & $-0,12$ & $26,60 * *$ & 1,84 & $-7,56$ & $-3,66$ \\
\hline & $9.03 \quad 12,3$ & bnlg0430 & $-0,78$ & $0,46 * * *$ & 0,52 & $-0,26^{*}$ & $31,89 * *$ & $-5,42 * *$ & $-12,21 *$ & 0,64 \\
\hline & $9.04 \quad 5,6$ & umc1107 & $-0,05$ & $0,61^{*}$ & 0,61 & $-0,07$ & 16,79 。 & $-2,57$ & $-8,74$ & $-1,52$ \\
\hline & $9.0534,1$ & bnlg 1012 & $-0,72$ & 0,41 & 0,23 & $-0,21 *$ & $28,45 *$ & 2,49 & $-6,91$ & $-1,50$ \\
\hline & $9.0613,8$ & umc1733 & $-0,12$ & 0,06 & 0,24 & $-0,02$ & 0,19 & $-1,97$ & $-0,59$ & $-3,07$ \\
\hline & $9.07-7,8$ & bnlg0619 & $-0,33$ & $-0,02$ & 0,25 & $-0,20$ & $-4,81$ & $-0,28$ & 2,14 & $-2,40$ \\
\hline & 9.07 & bnlg0128 & $-0,30$ & 0,00 & 0,08 & $-0,10$ & $-4,13$ & 5,08 & 0,56 & $-0,16$ \\
\hline \multirow[t]{12}{*}{10} & $10.00 \quad 9,8$ & phi0117 & $-0,63$ & $-0,49 *$ & $-0,34$ & $-0,07$ & $17,67 * *$ & 3,61 & 2,06 & $-1,74$ \\
\hline & $10.01 \quad 6,3$ & umc1319 & $-0,92$ & $-0,43 * * *$ & $-0,18$ & $-0,03$ & $15,80 *$ & $6,18^{*}$ & $11,48 * * *$ & $-1,56$ \\
\hline & $10.0240,7$ & bnlg 1451 & $-0,12$ & $-0,25^{*}$ & $-0,24$ & $-0,20^{*}$ & $14,36 *$ & $4,67 *$ & $11,02 * *$ & $-3,40^{*}$ \\
\hline & $10.03 \quad 7,3$ & bnlg0640 & $-1,26^{*}$ & $-0,02$ & 0,18 & 0,06 & $10,92_{\text {o o }}$ & $-1,28$ & $16,94 * *$ & 1,27 \\
\hline & $10.0427,0$ & bnlg 1526 & $-1,51 * *$ & $-0,41^{* *}$ & 0,24 & $-0,17$ & 9,53 & $-4,66$ & $13,32 * *$ & 0,38 \\
\hline & $10.057,0$ & umc1930 & $-1,39 * * *$ & 0,04 & 0,61 & $-0,16$ & $-37,09 * * * *$ & $-4,81^{*}$ & $15,93 * *$ & $2,61 * *$ \\
\hline & $10.0512,1$ & umc1506 & $-1,48 * * *$ & 0,09 & $0,89 *$ & $-0,03$ & $-43,46 * * *$ & $-2,15$ & $13,73 * *$ & $3,92 *$ \\
\hline & $10.07 \quad 0,2$ & umc1196 & $-1,75 * *$ & $-0,26$ & $0,84_{\text {o }}$ & $-0,38^{*}$ & $-48,01 * *$ & 5,63 & $12,34 * *$ & 3,62 \\
\hline & $10.07 \quad 0,1$ & umc1038 & $-1,88 * *$ & $-0,15$ & 0,63 。 & $-0,35$ & $-56,16 * *$ o & $7,39 *$ & 9,62 & 3,64 \\
\hline & $10.07 \quad 0,1$ & umc2021 & $-1,98 * * *$ & $-0,16$ & 0,49 。 & $-0,31$ & $-53,41 * *_{0}$ & 5,59 & $12,03 *$ & 4,17 \\
\hline & $10.07 \quad 1,4$ & umcl569 & $-2,31 * * * *$ & $-0,13$ & $0,94_{0}$ & $-0,23$ & $-57,67 * * 。$ & 4,21 & $15,82 *$ & 5,01 \\
\hline & 10.07 & bnlg 1839 & $-1,34 * *$ & 0,02 & 0,48 o & $-0,06$ & $-52,02 * *$ & $9,93^{*}$ & $9,31 * * *$ & 1,80 \\
\hline
\end{tabular}

${ }^{a}$ número do cromossomo; ${ }^{b}$ distância em centiMorgan (cM) entre locos adjacentes; ${ }^{c}$ Níveis de significância dos efeitos dos contrastes: * $\mathrm{P} \leq 0,05$; ** $\mathrm{P} \leq 0,01$; *** $\mathrm{P} \leq 0,001$; **** $\mathrm{P} \leq 0,0001$ e ***** $\mathrm{P} \leq 0,00001$; níveis de significância das interações contrastes por ambientes: o $\mathrm{B} 0,05$; oo $\mathrm{P} \leq 0,01$; ${ }^{\mathrm{e}}$ estimativas dos efeitos multiplicadas por $10^{-2}$. 
Tabela 12.Número de marcadores com significância para os coeficientes $\hat{\beta}_{1}, \hat{\beta}_{2}, \hat{\beta}_{3}$ e $\hat{\beta}_{4}$ e suas interações com ambientes, entre parênteses, em cada cromossomo para os caracteres produção de grãos (PG), prolificidade (PROL), diâmetro da espiga (DE) e comprimento da espiga (CE).

\begin{tabular}{|c|c|c|c|c|c|c|c|c|c|c|c|c|}
\hline \multirow{2}{*}{ Crom. $^{\mathrm{a}}$} & \multirow{2}{*}{ Caráter } & \multicolumn{4}{|c|}{ Significância } & \multicolumn{6}{|c|}{ Efeitos simultaneamente significativos } & \multirow{2}{*}{ Total $^{\mathrm{b}}$} \\
\hline & & $\hat{a}_{1}$ & $\hat{a}_{2}$ & $\beta_{\xi}$ & $\hat{a}_{4}$ & $\hat{a}_{1} \hat{a}_{2}$ & $\hat{a}_{1} \hat{a}_{3}$ & $\hat{a}_{1} \hat{a}_{4}$ & $\hat{a}_{2} \hat{a}_{3}$ & $\hat{a}_{2} \hat{a}_{4}$ & $\hat{a}_{3} \hat{a}_{4}$ & \\
\hline \multirow{4}{*}{$1(19)$} & PG & 11 & 4 & 17 & 6 & 3 & 10 & 3 & 4 & 3 & 6 & 18 \\
\hline & PROL & $5(1)$ & $3(1)$ & 14 & 4 & $2(1)$ & 6 & 1 & 3 & 1 & 4 & 15 \\
\hline & DE & $1(3)$ & $4(1)$ & 10 & 4 & 2 & 1 & 0 & 1 & 0 & 2 & 17 \\
\hline & $\mathrm{CE}$ & $7(4)$ & 6 & 13 & 2 & 1 & 8 & 2 & 5 & 1 & 1 & 17 \\
\hline \multirow[t]{4}{*}{$2(19)$} & PG & 6 & 1 & 16 & 3 & 1 & 6 & 1 & 1 & 0 & 2 & 17 \\
\hline & PROL & 9 & 2 & 11 & 1 & 2 & 7 & 0 & 1 & 0 & 0 & 14 \\
\hline & DE & $7(1)$ & 3 & 5 & 1 & 0 & 1 & 1 & 2 & 0 & 0 & 13 \\
\hline & $\mathrm{CE}$ & $6(1)$ & 9 & 14 & 2 & 3 & 4 & 2 & 7 & 1 & 2 & 18 \\
\hline \multirow[t]{4}{*}{3 (13) } & PG & 6 & 1 & $6(1)$ & 3 & 1 & 2 & 1 & 0 & 0 & 2 & 11 \\
\hline & PROL & 7 (1) & $0(1)$ & $0(1)$ & 5 & $0(1)$ & 1 & 3 & 1 & 0 & 0 & 9 \\
\hline & DE & 6 & 3 & 7 & 3 & 0 & 5 & 1 & 1 & 1 & 3 & 10 \\
\hline & $\mathrm{CE}$ & 6 & 6 & 2 & 3 & 2 & 1 & 2 & 0 & 3 & 0 & 11 \\
\hline \multirow[t]{4}{*}{4 (19) } & PG & $0(1)$ & $5(1)$ & 10 & 4 & $0(1)$ & 1 & 1 & 2 & 2 & 2 & 15 \\
\hline & PROL & $2(7)$ & $9(4)$ & 6 & 0 & $4(4)$ & 2 & 0 & 4 & 0 & 0 & 16 \\
\hline & DE & 8 & 7 & 2 & 3 & 3 & 1 & 0 & 0 & 0 & 0 & 16 \\
\hline & $\mathrm{CE}$ & 4 & 5 & 7 & 5 & 3 & 3 & 2 & 4 & 3 & 3 & 10 \\
\hline \multirow[t]{4}{*}{5 (16) } & PG & $6(4)$ & 1 & 11 & 6 & 0 & 3 & 2 & 1 & 0 & 5 & 15 \\
\hline & PROL & $8(2)$ & 2 & 9 & 2 & 2 & 5 & 1 & 2 & 0 & 2 & 14 \\
\hline & DE & 15 & 6 & 6 & 2 & 6 & 6 & 2 & 3 & 0 & 1 & 15 \\
\hline & $\mathrm{CE}$ & 7 & 4 & 9 & 5 & 1 & 7 & 3 & 2 & 2 & 4 & 11 \\
\hline \multirow[t]{4}{*}{6 (12) } & PG & 5 & 1 & 9 & 2 & 0 & 2 & 1 & 1 & 1 & 1 & 12 \\
\hline & PROL & 2 & 5 & 5 & 1 & 1 & 2 & 1 & 3 & 0 & 1 & 7 \\
\hline & $\mathrm{DE}$ & $6(2)$ & 4 & 4 & 1 & 4 & 3 & 1 & 2 & 0 & 0 & 9 \\
\hline & $\mathrm{CE}$ & 2 & 1 & 3 & $1(2)$ & 1 & 0 & 0 & 0 & 0 & 1 & 7 \\
\hline \multirow[t]{4}{*}{7 (9) } & PG & $5(1)$ & 3 & 5 & 2 & 1 & 5 & 1 & 0 & 1 & 0 & 9 \\
\hline & PROL & 7 & $1(1)$ & 1 & 3 & 1 & 1 & 1 & 0 & 1 & 0 & 9 \\
\hline & $\mathrm{DE}$ & 5 & $5(2)$ & 2 & 0 & 4 & 0 & 0 & 1 & 0 & 0 & 9 \\
\hline & $\mathrm{CE}$ & 7 & 1 & 6 & 5 & 0 & 5 & 5 & 0 & 0 & 4 & 9 \\
\hline \multirow[t]{4}{*}{8 (11) } & PG & $4(3)$ & 0 & 9 & 1 & 0 & 5 & 1 & 0 & 0 & 1 & 11 \\
\hline & PROL & $0(2)$ & $2(1)$ & 4 & 2 & 0 & 1 & 2 & 0 & 0 & 1 & 8 \\
\hline & $\mathrm{DE}$ & $6(1)$ & 1 & 6 & 1 & 0 & 4 & 1 & 1 & 0 & 0 & 8 \\
\hline & $\mathrm{CE}$ & 1 & 4 & 6 & 3 & 0 & 1 & 0 & 2 & 1 & 2 & 9 \\
\hline \multirow{4}{*}{9 (10) } & PG & 7 & 0 & 4 & 7 & 0 & 4 & 7 & 0 & 0 & 4 & 7 \\
\hline & PROL & 3 & 0 & 4 & 3 & 0 & 0 & 0 & 0 & 0 & 3 & 7 \\
\hline & DE & 4 & 5 & 3 & 4 & 1 & 1 & 3 & 2 & 2 & 2 & 9 \\
\hline & $\mathrm{CE}$ & 6 & 6 & 5 & 5 & 4 & 2 & 2 & 2 & 2 & 3 & 10 \\
\hline \multirow[t]{4}{*}{$10(12)$} & PG & 10 & 0 & 12 & 1 & 0 & 10 & 1 & 0 & 0 & 1 & 12 \\
\hline & PROL & $4(3)$ & 3 & 7 & $2(1)$ & 2 & 5 & 3 & 2 & 0 & 2 & 10 \\
\hline & DE & 10 & 2 & 12 & 2 & 1 & 10 & 2 & 2 & 0 & 2 & 12 \\
\hline & $\mathrm{CE}$ & 9 & 11 & 7 & 4 & 8 & 7 & 3 & 7 & 4 & 2 & 12 \\
\hline \multirow[t]{4}{*}{ Total } & PG & $60(9)$ & $16(1)$ & 99 (1) & 35 & $6(1)$ & 48 & 19 & 9 & 7 & 24 & $127(11)$ \\
\hline & PROL & 47 (16) & $27(8)$ & 61 (1) & $23(1)$ & $14(6)$ & 30 & 12 & 16 & 2 & 13 & 109 (20) \\
\hline & DE & $68(7)$ & $40(3)$ & 57 & 21 & 21 & 32 & 11 & 15 & 3 & 10 & $118(10)$ \\
\hline & $\mathrm{CE}$ & $55(5)$ & 53 & 72 & $35(2)$ & 23 & 38 & 21 & 29 & 16 & 22 & $114(7)$ \\
\hline
\end{tabular}

a Número do cromossomo e número de marcadores mapeados por cromossomo ${ }^{\mathrm{b}}$ total de marcadores que apresentaram significâncias para os efeitos $\beta_{1}, \beta_{2}, \beta_{3}$ e ou $\beta_{4}$. 
Tabela 13.Número de marcadores com significância para os coeficientes $\hat{\beta}_{1}, \hat{\beta}_{2}, \hat{\beta}_{3}$ e $\hat{\beta_{4}}$, e suas interações com ambientes, entre parênteses, em cada cromossomo para os caracteres número de ramificações por pendão (RP), peso de 500 grãos (P500), número de grãos por fileira por espiga (NGF) e número de fileiras por espiga (NFI).

\begin{tabular}{|c|c|c|c|c|c|c|c|c|c|c|c|c|}
\hline \multirow{2}{*}{ Crom. $^{\text {a }}$} & \multirow{2}{*}{ Caráter } & \multicolumn{4}{|c|}{ Significância } & \multicolumn{6}{|c|}{ Efeitos simultaneamente significativos } & \multirow{2}{*}{ Total $^{\mathrm{b}}$} \\
\hline & & $\hat{a}_{1}$ & $\hat{a}_{2}$ & $\beta_{y}$ & $\hat{a}_{4}$ & $\hat{a}_{1} \hat{a}_{2}$ & $\hat{a}_{1} \hat{a}_{3}$ & $\hat{a}_{1} \hat{a}_{4}$ & $\hat{a}_{2} \hat{a}_{3}$ & $\hat{a}_{2} \hat{a}_{4}$ & $\hat{a}_{3} \hat{a}_{4}$ & \\
\hline \multirow{4}{*}{ 1(19) } & RP & 8 & 5 & 7 & 6 & 3 & 2 & 3 & 2 & 1 & 2 & 16 \\
\hline & P500 & $11(1)$ & 3 & 12 & 1 & 2 & 7 & 0 & 3 & 0 & 1 & 17 \\
\hline & NGF & $5(5)$ & 2 & 15 & 2 & 0 & 6 & 1 & 2 & 0 & 1 & 18 \\
\hline & NFI & 11 & 9 & 2 & 5 & 6 & 2 & 3 & 0 & 3 & 0 & 15 \\
\hline \multirow[t]{4}{*}{$2(19)$} & RP & 14 & 5 & 8 & 2 & 5 & 3 & 0 & 1 & 0 & 2 & 19 \\
\hline & P500 & 11 & 1 & 7 & 4 & 1 & 3 & 3 & 0 & 0 & 0 & 16 \\
\hline & NGF & 4 & 5 & 17 & 3 & 1 & 3 & 1 & 5 & 0 & 3 & 18 \\
\hline & NFI & 15 & 7 & 0 & 0 & 5 & 0 & 0 & 0 & 0 & 0 & 17 \\
\hline \multirow{4}{*}{$3(13)$} & RP & 4 & 6 & 7 & 2 & 1 & 1 & 1 & 3 & 2 & 1 & 12 \\
\hline & P500 & $10(2)$ & $1(1)$ & 7 & 0 & 1 & 6 & 0 & 1 & 0 & 0 & 13 \\
\hline & NGF & 4 & 4 & 6 & 3 & 0 & 2 & 1 & 2 & 2 & 1 & 10 \\
\hline & NFI & 9 & 6 & 1 & 1 & 4 & 0 & 1 & 0 & 1 & 0 & 12 \\
\hline \multirow[t]{4}{*}{$4(19)$} & RP & 14 & 9 & 1 & 2 & 9 & 1 & 1 & 0 & 1 & 0 & 15 \\
\hline & P500 & 2 & $10(1)$ & 3 & 4 & 0 & 1 & 1 & 2 & 0 & 0 & 16 \\
\hline & NGF & $1(2)$ & $2(1)$ & 5 & 11 & 0 & 1 & 1 & 1 & 1 & 1 & 17 \\
\hline & NFI & 10 & $6(3)$ & 0 & 1 & 3 & 0 & 0 & 0 & 0 & 0 & 17 \\
\hline \multirow[t]{4}{*}{$5(16)$} & RP & 13 & 7 & 10 & 0 & 5 & 10 & 0 & 5 & 0 & 0 & 15 \\
\hline & P500 & $4(5)$ & 4 & 8 & 0 & 2 & 4 & 0 & 3 & 0 & 0 & 14 \\
\hline & NGF & 10 & 4 & 9 & 2 & 2 & 4 & 0 & 2 & 0 & 2 & 16 \\
\hline & NFI & 10 & 2 & 1 & 2 & 1 & 1 & 2 & 0 & 0 & 0 & 11 \\
\hline \multirow[t]{4}{*}{$6(12)$} & RP & 4 & 9 & 2 & 1 & 4 & 1 & 1 & 2 & 1 & 0 & 9 \\
\hline & P500 & 4 & 4 & 2 & 2 & 1 & 1 & 1 & 2 & 2 & 1 & 7 \\
\hline & NGF & 3 & 5 & 8 & 3 & 0 & 0 & 1 & 4 & 1 & 2 & 12 \\
\hline & NFI & 6 & 2 & 2 & 0 & 1 & 1 & 0 & 0 & 0 & 0 & 8 \\
\hline \multirow[t]{4}{*}{7 (9) } & RP & 4 & 2 & 5 & 4 & 1 & 2 & 0 & 1 & 0 & 3 & 9 \\
\hline & P500 & 5 & 1 & 4 & 3 & 0 & 2 & 1 & 1 & 1 & 2 & 8 \\
\hline & NGF & 5 & 1 & 5 & 5 & 0 & 3 & 3 & 0 & 0 & 3 & 9 \\
\hline & NFI & 4 & 1 & 2 & 4 & 1 & 0 & 3 & 1 & 0 & 01 & 6 \\
\hline \multirow[t]{4}{*}{8 (11) } & $\mathrm{RP}$ & 10 & 2 & 4 & 2 & 2 & 3 & 2 & 0 & 0 & 1 & 11 \\
\hline & P500 & $1(4)$ & 2 & 8 & 1 & 0 & 4 & 0 & 1 & 0 & 1 & 10 \\
\hline & NGF & 1 & 3 & 5 & 1 & 1 & 0 & 0 & 0 & 0 & 1 & 8 \\
\hline & NFI & 8 & 5 & $0(2)$ & 1 & 4 & 2 & 1 & 1 & 0 & 0 & 9 \\
\hline \multirow[t]{4}{*}{9 (10) } & RP & $6(3)$ & 4 & 1 & 3 & 4 & 1 & 3 & 1 & 3 & 0 & 7 \\
\hline & P500 & 1 & 6 & 4 & 2 & 1 & 1 & 0 & 4 & 1 & 0 & 7 \\
\hline & NGF & 0 & 1 & 3 & 6 & 0 & 0 & 0 & 0 & 1 & 3 & 6 \\
\hline & NFI & 3 & 6 & 1 & 2 & 3 & 0 & 1 & 0 & 1 & 0 & 8 \\
\hline \multirow[t]{4}{*}{10 (12) } & RP & $10(5)$ & 5 & 10 & 3 & 5 & 9 & 3 & 4 & 2 & 3 & 12 \\
\hline & P500 & 9 & 4 & $1(5)$ & 2 & 1 & 6 & 1 & 0 & 1 & 1 & 12 \\
\hline & NGF & 6 & 1 & 12 & 4 & 1 & 6 & 2 & 1 & 0 & 4 & 12 \\
\hline & NFI & 6 & 10 & 1 & 0 & 5 & 1 & 0 & 1 & 0 & 0 & 11 \\
\hline \multirow[t]{4}{*}{ Total } & $\mathrm{RP}$ & $87(8)$ & 54 & 55 & 25 & 39 & 33 & 14 & 19 & 10 & 12 & $125(8)$ \\
\hline & P500 & $58(12)$ & $36(2)$ & $56(5)$ & 19 & 9 & 35 & 7 & 17 & 5 & 6 & $120(19)$ \\
\hline & NGF & $39(7)$ & $28(1)$ & 85 & 40 & 5 & 25 & 10 & 17 & 5 & 21 & $126(8)$ \\
\hline & NFI & 82 & $54(3)$ & $10(2)$ & 16 & 33 & 7 & 11 & 2 & 5 & 1 & $114(3)$ \\
\hline
\end{tabular}

${ }^{a}$ Número do cromossomo e número de marcadores mapeados por cromossomo ${ }^{\text {b total de marcadores que apresentaram }}$ significâncias para os efeitos $\beta_{1}, \beta_{2}, \beta_{3}$ e ou $\beta_{4}$. 
Tabela 14. Amplitude de variação das estimativas dos coeficientes de regressão significativos para os caracteres PG, PROL, DE, CE, NGF, NFI, P500 e RP.

\begin{tabular}{|c|c|c|c|c|c|c|c|c|c|c|c|c|}
\hline \multirow[b]{2}{*}{ Caráter } & \multirow[b]{2}{*}{ Coef. } & & \multicolumn{10}{|c|}{ Cromossomos } \\
\hline & & & 1 & 2 & 3 & 4 & 5 & 6 & 7 & 8 & 9 & 10 \\
\hline \multirow{7}{*}{$\begin{array}{c}\text { PG } \\
\left(\text { g planta }^{-1}\right)\end{array}$} & & Maior & 1,16 & $-0,69$ & $-0,76$ & \multirow[t]{2}{*}{-} & 2,45 & $-1,21$ & $-2,01$ & 2,10 & $-0,80$ & $-0,95$ \\
\hline & $\beta_{1}$ & Menor & $-2,69$ & $-1,85$ & $-2,13$ & & 1,78 & $-1,93$ & $-3,57$ & 1,66 & $-2,22$ & $-5,17$ \\
\hline & $\hat{\beta}_{2}$ & Maior & $\begin{array}{r}0,62 \\
-072\end{array}$ & $-0,37$ & $-0,68$ & $\begin{array}{r}0,51 \\
-0(0)\end{array}$ & $-0,58$ & 0,33 & $\begin{array}{r}0,80 \\
-0,52\end{array}$ & -- & -- & -- \\
\hline & \multirow{2}{*}{$\hat{\beta}_{3}$} & Maior & 4,19 & 4,06 & 2,28 & 2,13 & 4,10 & 3,42 & 3,57 & \multirow{2}{*}{$\begin{array}{r}2,96 \\
-0,72\end{array}$} & 2,06 & \multirow{2}{*}{$\begin{array}{l}5,73 \\
1,29\end{array}$} \\
\hline & & Menor & 1,15 & 0,74 & 1,07 & 0,74 & 0,97 & 0,76 & 1,28 & & 1,56 & \\
\hline & \multirow{2}{*}{$\hat{\beta}_{4}$} & Maior & 0,67 & 0,56 & 0,84 & 0,27 & $-0,42$ & $-0,41$ & 0,38 & \multirow{2}{*}{$-0,32$} & $-0,39$ & \multirow{2}{*}{0,46} \\
\hline & & Menor & $-0,68$ & $-0,77$ & $-0,64$ & $-1,19$ & $-1,04$ & $-0,92$ & $-0,63$ & & $-0,99$ & \\
\hline \multirow{8}{*}{$\begin{array}{c}\text { PROL }^{a} \\
(\text { esp. } \\
\left.\text { planta }^{-1}\right)\end{array}$} & \multirow{2}{*}{$\hat{\beta}_{1}$} & Maior & $-9,69$ & $-10,28$ & $-6,27$ & 7,39 & 16,43 & $-5,84$ & $-9,62$ & \multirow[t]{2}{*}{--} & $-9,96$ & $-9,87$ \\
\hline & & Menor & $-15,73$ & $-21,67$ & $-22,40$ & 6,06 & $-11,15$ & $-13,38$ & $-26,01$ & & $-10,78$ & $-15,07$ \\
\hline & \multirow{2}{*}{$\hat{\beta}_{2}$} & Maior & $-2,51$ & 4,13 & \multirow[t]{2}{*}{ 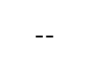 } & 6,79 & 2,89 & 4,69 & \multirow{2}{*}{5,35} & $-2,12$ & \multirow{2}{*}{-- } & $-3,21$ \\
\hline & & Menor & $-6,18$ & $-5,06$ & & $-3,68$ & $-3,35$ & 3,37 & & $-5,22$ & & $-4,37$ \\
\hline & \multirow{2}{*}{$\hat{\boldsymbol{\beta}}_{3}$} & Maior & 21,69 & 15,63 & -- & 8,48 & 14,94 & 14,85 & 10,28 & 14,14 & 13,09 & 11,19 \\
\hline & & Menor & 7,15 & 6,05 & & 4,90 & 6,78 & 7,70 & & 10,39 & 10,41 & 5,37 \\
\hline & & Maior & 5,64 & 3,44 & 4,47 & -- & $-2,36$ & $-3,09$ & 4,41 & $-1,65$ & $-3,12$ & $-2,90$ \\
\hline & & Menor & 2,39 & & $-3,20$ & & $-3,06$ & & 2,11 & $-3,55$ & $-5,14$ & $-3,89$ \\
\hline & & Maior & 18.62 & 30,25 & 20,87 & $-4,76$ & 27,17 & $-7,27$ & 7,74 & 26,48 & $-13,00$ & 24,89 \\
\hline & & Menor & & $-18,54$ & $-17,72$ & $-14,15$ & 8,15 & $-20,30$ & $-12,25$ & 9,36 & $-17,92$ & $-43,97$ \\
\hline & & Maior & 6,26 & 2,68 & $-3,15$ & 4,74 & 5,64 & $-2,81$ & 5,82 & -147 & 4,18 & 3,32 \\
\hline$E^{\mathrm{u}}$ & & Menor & $-6,98$ & $-6,67$ & $-8,11$ & $-5,94$ & $-4,48$ & $-5,29$ & $-5,24$ & & $-6,04$ & $-3,77$ \\
\hline$\left(\mathrm{cm} \mathrm{esp.} .^{-1}\right)$ & & Maior & 16,43 & 11,78 & 22,29 & 9,07 & 16,99 & 13,26 & 7,72 & 12,83 & 7,74 & 22,95 \\
\hline & & Menor & 7,32 & $-5,89$ & $-9,73$ & 6,38 & 4,52 & 9,27 & $-10,35$ & 8,63 & 5,43 & 7,09 \\
\hline & & Maior & 5,22 & 4,29 & 5,10 & 3,08 & $-2,18$ & $-2,67$ & -- & 3,71 & $-4,61$ & 3,25 \\
\hline & & Menor & $-6,13$ & & $-5,76$ & $-3,35$ & $-3,56$ & & & & $-5,49$ & $-2,80$ \\
\hline & & Maior & 13,20 & 11,77 & 10,56 & 8,93 & 5,67 & 5,99 & 12,44 & $-6,89$ & $-4,11$ & 3,78 \\
\hline & & Menor & $-7,93$ & $-7,51$ & $-5,22$ & 3,64 & $-7,80$ & 5,29 & $-8,01$ & & $-9,18$ & $-12,49$ \\
\hline & & Maior & 2,45 & 5,21 & 4,65 & 2,20 & 2,07 & $-2,42$ & 3,38 & 2,86 & 3,15 & 7,22 \\
\hline $\mathrm{CE}^{\mathrm{b}}$ & & Menor & $-4,22$ & $-3,17$ & $-3,45$ & $-2,63$ & $-2,28$ & $-2,+2$ & & $-2,45$ & 1,31 & $-3,92$ \\
\hline$\left(\mathrm{cm} \mathrm{esp} .^{-1}\right)$ & & Maior & 9,33 & 9,71 & 4,98 & 9,13 & 10,77 & 9,13 & 11,26 & 8,07 & 6,26 & 19,46 \\
\hline & & Menor & 3,56 & 2,56 & 4,36 & 4,38 & 4,17 & 5,00 & $-4,03$ & 5,50 & 4,50 & 10,19 \\
\hline & & Maior & 1,80 & 1,50 & $-1,19$ & 0,71 & $-1,03$ & $-2,76$ & $-1,73$ & 1,87 & $-1,83$ & 1,83 \\
\hline & & Menor & $-2,88$ & 1,07 & $-2,96$ & $-1,84$ & $-3,02$ & & $-3,18$ & $-2,46$ & $-2,35$ & 1,22 \\
\hline & & Maior & 25,08 & 22,26 & 23,02 & 15,60 & 21,20 & $-14,24$ & 20,09 & 13,72 & -- & 10,81 \\
\hline & & Menor & $-27,80$ & $-21,92$ & $-13,83$ & 10,00 & $-25,09$ & $-16,46$ & $-18,76$ & 10,12 & & $-46,38$ \\
\hline $\mathrm{NGF}^{\mathrm{a}}$ & & Maior & 8,28 & 8,64 & 7,59 & 9,32 & 4,60 & 7,75 & 6,36 & 7,16 & 4,48 & $-11,45$ \\
\hline (n ${ }^{\circ}$. grãos & & Menor & 7,84 & $-8,74$ & $-16,52$ & 7,71 & $-7,63$ & $-7,12$ & & 3,49 & & \\
\hline $\left.\operatorname{esp}^{-1}.\right)$ & $\hat{\beta}_{3}$ & Maior & 27,26 & 38,55 & 18,35 & 18,51 & 27,43 & 24,83 & 32,54 & 23,00 & 18,68 & 57,95 \\
\hline & & Menor & 11,76 & 12,51 & 9,97 & 10,63 & 11,89 & 11,92 & 12,26 & 13,61 & 13,64 & 15,28 \\
\hline & & Maior & 5,57 & 5,03 & $-2,99$ & $-4,25$ & 3,09 & $-5,17$ & $-4,12$ & 5,42 & $-4,54$ & 9,47 \\
\hline & & Menor & $-5,94$ & $-3,58$ & $-5,12$ & $-10,95$ & $-5,48$ & $-7,79$ & $-7,20$ & & $-6,96$ & 4,97 \\
\hline
\end{tabular}


Tabela 14. Amplitude de variação das estimativas dos coeficientes de regressão significativos para os caracteres PG, PROL, DE, CE, NGF, NFI, P500 e RP.

\begin{tabular}{|c|c|c|c|c|c|c|c|c|c|c|c|c|}
\hline \multirow[b]{2}{*}{ Caráter } & \multirow[b]{2}{*}{ Coef. } & & \multicolumn{10}{|c|}{ Cromossomos } \\
\hline & & & 1 & 2 & 3 & 4 & 5 & 6 & 7 & 8 & 9 & 10 \\
\hline \multirow{7}{*}{$\begin{array}{l}\mathrm{NFI}^{\mathrm{b}} \\
\left(\mathrm{n}^{\mathrm{o}} . \text { fil. }\right. \\
\left.\mathrm{esp}^{-1} .\right)\end{array}$} & \multirow{2}{*}{$\hat{\beta_{1}}$} & Maior & 19,02 & 24,02 & 9,17 & 8,04 & 10,92 & $-4,97$ & 8,77 & 12,74 & 7,49 & 22,56 \\
\hline & & Menor & 3,56 & $-5,02$ & $-7,31$ & $-9,69$ & $-4,86$ & $-12,12$ & 2,89 & 2,33 & 4,38 & 5,20 \\
\hline & \multirow{2}{*}{$\hat{\beta}_{2}$} & Maior & 3,83 & 1,94 & 3,47 & 2,86 & 1,75 & 1,74 & \multirow{2}{*}{$-2,78$} & 2,80 & $-2,40$ & 4,40 \\
\hline & & Menor & $-3,92$ & $-3,39$ & $-2,29$ & $-4,49$ & $-1,89$ & $-4,22$ & & $-2,22$ & $-4,85$ & 1,30 \\
\hline & $\hat{\beta}_{3}$ & $\begin{array}{l}\text { Maior } \\
\text { Menor }\end{array}$ & $\begin{array}{r}2,81 \\
-2,38\end{array}$ & -- & $-3,27$ & -- & $-1,45$ & $\begin{array}{l}2,93 \\
2,80\end{array}$ & $-2,71$ & -- & $-3,69$ & 2,32 \\
\hline & \multirow{2}{*}{$\hat{\beta}_{4}$} & Maior & 2,44 & \multirow{2}{*}{--} & \multirow{2}{*}{1,04} & \multirow{2}{*}{1,53} & $-1,30$ & \multirow{2}{*}{-- } & $-1,20$ & \multirow{2}{*}{1,71} & 1,73 & \multirow{2}{*}{--} \\
\hline & & Menor & $-1,75$ & & & & $-1,88$ & & $-2,40$ & & 1,16 & \\
\hline \multirow{8}{*}{$\begin{array}{c}\mathrm{RP}^{\mathrm{a}} \\
(\mathrm{ram} \\
\text { pendão-1 }\end{array}$} & \multirow{2}{*}{$\hat{\beta}_{1}$} & Maior & 26,71 & 77,90 & 13,56 & $-12,63$ & 22,76 & $-10,05$ & 22,92 & 32,11 & 31,89 & 17,67 \\
\hline & & Menor & $-17,36$ & 14,42 & $-27,88$ & $-42,19$ & $-40,38$ & $-12,72$ & $-17,28$ & 11,24 & 12,81 & $-57,67$ \\
\hline & \multirow{2}{*}{$\hat{\beta}_{2}$} & Maior & 7,47 & $-3,30$ & 9,40 & 3,98 & $-2,72$ & 8,39 & 4,13 & 1,69 & $-4,26$ & 9,93 \\
\hline & & Menor & $-5,53$ & $-7,92$ & 3,84 & $-9,94$ & $-9,18$ & $-16,15$ & 3,85 & $-9,12$ & $-11,07$ & $-4,81$ \\
\hline & \multirow{2}{*}{$\hat{\beta}_{3}$} & Maior & 22,07 & 14,74 & 14,24 & \multirow{2}{*}{9,64} & 22,81 & 6,21 & 22,43 & 11,01 & \multirow{2}{*}{$-12,21$} & 16,94 \\
\hline & & Menor & 11,10 & 7,77 & 6,23 & & 10,21 & $-9,73$ & 10,14 & 6,97 & & 9,31 \\
\hline & \multirow{2}{*}{$\hat{\beta}_{4}$} & Maior & 4,22 & 6,23 & 3,14 & $-3,48$ & -- & 5.00 & $-3,16$ & 5,08 & $-4,04$ & 3,92 \\
\hline & & Menor & $-6,43$ & 3,64 & $-3,27$ & $-7,48$ & & & $-6,81$ & 3,50 & $-4,96$ & $-3,40$ \\
\hline & $\hat{\beta}$ & Maior & $-2,29$ & $-0,62$ & 1,95 & $-1,20$ & 1,59 & 1,30 & 1,55 & 0,92 & $-1,28$ & $-1,26$ \\
\hline & & Menor & $-0,71$ & $-2,02$ & $-1,59$ & $-1,05$ & 0,82 & 0,32 & $-0,96$ & & & $-2,31$ \\
\hline & & Maior & 0,62 & 0,15 & $-0,69$ & 0,44 & 0,37 & 0,31 & $-0,27$ & $-0,59$ & 0,61 & $-0,25$ \\
\hline $\mathrm{P} 500^{\mathrm{b}}$ & $\beta_{2}$ & Menor & 0,26 & $0,1 J$ & $-0,0\rangle$ & $-0,45$ & $-0,37$ & $-0,67$ & & $-0, J 3$ & 0,39 & $-0,49$ \\
\hline (g) & $\hat{\boldsymbol{Q}}$ & Maior & 1,35 & 0,97 & 1,20 & 0,81 & 1,20 & 0,42 & 1,30 & 1,45 & 0,89 & 0.89 \\
\hline & & Menor & 0,71 & 0,59 & 0,63 & 0,77 & 0,54 & 0,39 & 0,89 & $-0,41$ & 0,62 & \\
\hline & $\hat{\boldsymbol{\beta}}$ & Maior & 0,20 & 0,51 & -- & $-0,17$ & -- & $-0,19$ & 0,32 & $-0,24$ & $-0,26$ & $-0,20$ \\
\hline & & Menor & & $-0,15$ & & $-0,28$ & & $-0,32$ & $-0,31$ & & $-0,21$ & $-0,38$ \\
\hline
\end{tabular}

${ }^{\mathrm{a}}$ valores multiplicados por $10^{-3} ;{ }^{\mathrm{b}}$ valores multiplicados por $10^{-2}$. -- Não detectados coeficientes significativos. 


\section{REFERÊNCIAS BIBLIOGRÁFICAS}

ALEXANDER, W.L.; SMITH, E.L.; DHANASOBHAN, C. A comparison of yield and yield component selection in winter wheat. Euphytica, v.33, p.953-961, 1984.

ARIAS, C.A.A.; SOUZA JUNIOR, C.L.; TAKEDA, C. Path coefficient analyses of ear weight in different types of progeny in maize. Maydica, v.44, p.251-262, 1999.

AUSTIN, D.F.; LEE, M. Comparative mapping in $\mathrm{F}_{2: 3}$ and $\mathrm{F}_{6: 7}$ generations of quantitative trait loci for grain yield and yield components in maize. Theoretical Applied Genetics, v.92, p.817-826, 1996.

AUSTIN, D.F.; LEE, M. Detection of quantitative trait loci for grain yield and yield components in maize across generations in stress and nonstress environments. Crop Science, v.38, p.1296-1308, 1998.

BARBIN, D. Componentes de variância. Piracicaba: FEALQ, 1993. 108p.

BEARZOTI, E. Mapeamento de QTL. In: JORNADA EM GENÉTICA E MELHORAMENTO DE PlANTAS, 2., Goiânia, 2000. Análise de QTL no melhoramento de plantas. Goiânia: UFG, 2000. 232p.

BENSON, D.L.; HALLAUER, A.R. Inbreeding depression rates in maize populations before e after recurrent selection. Journal of Heredity, v.85, p.122-128, 1994.

BERKE, T.G.; ROCHEFORD, T.R. Quantitative trait loci for flowering, plant an ear height, and kernel traits in maize. Crop Science, v.35, p.1542-1549, 1995.

BERKE, T.G.; ROCHEFORD, T.R. Quantitative trait loci for tassel traits in maize. Crop Science, v.39, p.1439-1443, 1999. 
BURDICK, R.K.; GRAYBILL, F.A. Confidence intervals on variance components. New York: Marcel Dekker, 1992. 211p.

CARDOSO, R.G. Depressão por endogamia dos componentes da produção em populações e híbridos de milho (Zea mays L.). Piracicaba, 1999. 134p. Tese (Doutorado) - Escola Superior de Agricultura "Luiz de Queiroz", Universidade de São Paulo.

COCKERHAM, C.C. An extension of the concept of partitioning hereditary variance for analysis of covariance among relatives when epistasis is present. Genetics, v.39, p.859-882, 1954.

COCKERHAM, C.C.; ZENG, Z.-B. Design III with marker loci. Genetics, v.143, p.1437-1456, 1996.

COMSTOCK, R.E.; ROBINSON, H.F. Estimation of average dominance genes. In: GOWEN, J.W. (Ed.). Heterosis. Ames: Iowa State College Press, 1952. cap.30, p.494-516.

COMSTOCK, R.E.; ROBINSON, H.F. The components of genetic variance in populations of biparental progenies and their use in estimating the average degree of dominance. Biometrics, v.4, p.254-266, 1948.

DARRAH, L.L.; HALLAUER, A.R. Genetic effects estimated from generation means in four diallel sets of maize inbreds. Crop Science, v.12, p.615-621, 1972.

DUDLEY, J.W. Linkage disequilibrium in crosses between Illinois maize strains divergently selected for protein percentage. Theoretical Applied of Genetics, v.87, n.8, p.1016-1020, 1994.

DUNCAN, W.G.; McCLOUD, D.E.; McGRAW，R.L.; BOOTE，K.J. Physiological aspects of peanut yield improvement. Crop Science, v.18, p.1015-1020, 1978. 
EBERHART, S.A.; MOLL, R.H.; ROBINSON, H.F.; COCKERHAM, C.C. Epistatic and other genetic variances in two varieties of maize. Crop Science, v.6, p.275-280, 1966.

EDWARDS, M.D.; STUBER, C.W.; WENDEL, J.F. Molecular-marker-facilitated investigations of quantitative-trait loci in maize. I. Numbers, genomic distribution and types of gene action. Genetics, v.116, p.113-125, 1987.

FALCONER, D.S.; MACKAY, T.F.C. Introduction to quantitative genetics. 4.ed. Harlow: Addison Wesley Longman, 1996. 464p.

FEIL, B. Breeding progress in small grain cereals: a comparison of old and modern cultivars. Plant Breeding, v.1, p.1-11, 1992.

FREY, K.J. Increasing grain yield of oats. Plant Physiology and Biochemistry, v.26, p.539-542, 1988.

GAMBLE, E.E. Gene effects in corn (Zea mays L.) I. Separation and relative importance of gene effects for yield. Canadian Journal of Plant Science, v.42, p.339-348, 1962.

GARDNER, C.O. Quantitative genetic studies and population improvement in maize and sorghum. In: POLLAK, E.; KEMPTHORNE, O.; BARLEY, T.B. Jr. (Ed.). Breeding. Ames: The Iowa State University Press, 1977. p.475-489.

GARDNER, C.O.; HARVEY, P.H.; COMSTOCK, R.E.; ROBINSON, H.F. Dominance of genes controlling quantitative characters in maize. Agronomy Journal, v.45, n.5, p.186-191, 1953.

GARDNER, C.O.; LONQUIST, J.H. Linkage and the degree of dominance of genes controlling quantitative characters in maize. Agronomy Journal, v.51, p.524-528, 1959. 
GEADELMANN, J.L.; PETERSON, R.H. Effects of yield component selection on the general combining ability of maize inbred lines. Crop Science, v.16, p.807-811, 1976.

GERALDI, I.O.; MIRANDA FILHO, J.B.; VENCOVSKY, R. Estimates of genetic parameters for tassel characters in maize (Zea mays L.) and breeding perspectives. Maydica, v.30, n.1, p.1-14, 1985.

GERALDI, I.O.; VENCOVSKY, R. Depressão por endogamia em populações de milho. In: REUNIÃO BRASILEIRA DE MILHO E SORGO, 13., Londrina, 1980. Resumos. Londrina: IAPAR, 1980. p.45.

GOODMAN, M.M. Estimates of genetic variance in adapted and exotic population of maize. Crop Science, v.5, n.1, p.87-90, 1965.

GRAFUIS, J.E. Heterosis in barley. Agronomy Journal, v.51, p.551-554, 1959.

GROMBACHER, A.W.; RUSSELL, W.A.; GUTHRIE, W.D. Effects of recurrent selection in two maize synthetics on agronomic traits of $S_{1}$ lines. Maydica, v.34, p.343-352, 1989.

HALEY, C.S.; KNOTT, S.A. A simple regression method for mapping quantitative trait loci in line crosses using flaking markers. Heredity, v.69, p.315-324, 1992.

HALLAUER, A.R. Heritability of prolificacy in maize. Journal of Heredity, v.65, p.163-168, 1974.

HALLAUER, A.R.; MIRANDA FILHO, J.B. Quantitative genetics in maize breeding. Ames: Iowa State University Press, 1988. 468p.

HAN, G.-C.; HALLAUER, A.R. Estimates of genetic variability in $F_{2}$ maize populations. Journal of Iowa Academic Science, v.96, n.1, p.14-19, 1989.

HARRIS, R.E.; MOLL, R.H.; STUBER, C.W. Control and inheritance of prolificacy in maize. Crop Science, v.16, p.843-850, 1976. 
HINZE, L.L.; LAMKEY, K.R. Absence of epistasis for grain yield in elite maize hybrids. Crop Science, v.43, p.46-56, 2003.

HOISINGTON, D.; KHAIRALLAH, M.M.; GONZALES-DE-LÉON, D. Laboratory protocols. CIMMYT applied molecular genetics laboratory. 2.ed. México: CIMMYT, 1994. 180p.

HOLTHAUS, J.F.; LAMKEY, K.R. Response to selection and changes in genetic parameters for 13 plant and ear traits in two maize recurrent selection programs. Maydica, v.40, p.357-370, 1995.

JANSEN, R.C. A general mixture model for mapping quantitative trait loci by using molecular markers. Theoretical and Applied Genetics, v.85, p.252-260, 1992.

JANSEN, R.C. Maximum likelihood in a generalized linear finite mixture model by using the EM algorithm. Biometrics, v.49, p.227-231, 1993.

JOHNSON, V.A.; SCHMIDT, J.W.; MEKASHA, W. Comparison of yield components and agronomic characteristics of four winter wheat varieties differing in plant height. Agronomy Journal, v.58, p.438-441, 1966.

KAO, C.H.; ZENG, Z.-B.; TEASDALE, R.D. Multiple interval mapping for quantitative trait loci. Genetics, v.152, p.1203-1216, 1999.

KHANDAY, B.A.; THAKUR, R.C. Correlation of yield components in rainfed maize (Zea mays). Indian Journal of Agricultural Sciences, v.60, p.830-831, 1990.

KNAPP, S.J.; STROUP, W.W.; ROSS, W.M. Exact confidence intervals for heritability on a progeny mean basis. Crop Science, v.25, n.1, p.192-194, 1985.

LANDER, E.S.; BOTSTEIN, D. Mapping mendelian factors underlying quantitative traits using RFLP linkage maps. Genetics, v.121, p.185-199, 1989.

LEMOS, M.A.; GAMA, E.E.G.; OLIVEIRA, A.C. de; ARAÚJO, M.R.A. de. Correlações genotípicas, fenotípicas e ambientais em progênies de milho. Pesquisa Agropecuária Brasileira, v.27, p.1563-1569, 1992. 
LENG, E.R. Effects of heterosis on the major components of grain yield in com. Agronomy Journal, v.46, p.502-506, 1954.

LIMA, M.; MIRANDA FILHO, J.B.; GALLO, P.B. Inbreeding depression in brazilian populations of maize (Zea mayz L.). Maydica, v.29, p.203-215, 1984.

LINCOLN, S.E.; DALY, M.J.; LANDER, E.S. Construction genetic maps with Mapmaker Exp 3.0. 3.ed. Cambridge: Whitehead Institute for Biometrical Research, 1992. 230p.

LIU, B.H. QTL mapping: future considerations. In: LIU, B.H. (Ed.). Statistic genomics. New York: CRC Press, 1998. 611p.

LONQUIST, J.H.; COTA, O.A.; GARDNER, C.O. Effects of mass selection and thermal neutron irradiation on genetic variance in a variety of corn (Zea mays L.). Crop Science, v.6, p.330-332, 1966.

LYNCH, M.; WALSH, B. Genetics and analysis of quantitative traits. Sunderland: Sinauer Associates, 1998. 980p.

MADDONNI, G.A.; OTEGUI, M.E.; BONHOMME, R. Grain yield components in maize II. Postsilking growth and kernel weight. Field Crops Research v.53, p.247256, 1998.

MALVAR, R.A.; ORDÁS, A.; REVILLA, P.; CARTEA, M.E. Estimates of genetic variances in two spanish populations of maize. Crop Science, v.36, p.291-295, 1996.

MARECK, J.H.; GARDNER, C.O. Response to mass selection maize and stability of resulting populations. Crop Science, v.19, n.6, p.779-783, 1979.

MATHER, K.; JINKS, J.L. Introdução à genética biométrica. Trad. de J.F.M. Duarte, F.M. Sene, H.A. Rothschild et al. Ribeirão Preto: Sociedade Brasileira de Genética, 1984. 242p. 
McMUllAN, P.M.; McVETTY, P.B.E.; URQUHART, A.A. Dry matter and nitrogen accumulation and redistribution and their relationship to grain yield and grain protein in oats. Canadian Journal of Plant Science, v.68, p.983-993, 1988.

McNEAL, F.H.; QUALSET, C.O.; BALDRIDGE, D.E.; STEWART, V.R. Selection for yield and yield components in wheat. Crop Science, v.18, p.616-619, 1978.

MEGHJI, M.R.; DUDLEY, J.W.; LAMBERT, R.T.; SPRAGUE, G.F. Inbreeding depression, inbred and hybrid grain yield and other traits of maize genotype representing three eras. Crop Science, v.24, n.3, p.545-549, 1984.

MEHTA, H.; SARKAR, K.R. Heterosis for leaf photosynthesis, grain yield and yield components in maize. Euphytica, v.61, p.161-168, 1992.

MICKELSON, S.M.; STUBER, C.S.; SENIOR, L.; KAEPPLER, S.M. Quantitative trait loci controlling leaf and tassel traits in a B73 x Mo17 population of maize. Crop Science, v.42, p.1902-1909, 2002.

MOCK, J.J.; SCHUETZ, S.H. Inheritance of tassel branch number in maize. Crop Science, v.14, p.885-888, 1974.

MOLL, R.H.; KAMPRATH, E.J. Effects of population density upon agronomic traits associated with genetic increases in yield of Zea mays L.. Agronomy Journal, v.69, n.1, p.81-84, 1977.

MOLL, R.H.; LINDSEY, M.F.; ROBINSON, H.F. Estimates of genetic variances and level of dominance in maize. Genetics, v.49, n.3, p.411-423, 1964.

MORENO-GONZÁLEZ, J.; DUDLEY, J.W.; LAMBERT, R.J. A design III study of linkage disequilibrium for percent oil in maize. Crop Science, v.15, p.840-843, 1975.

MOSER, H.S.; FREY, K.J. Yield component responses associated with increased groat yield after recurrent selection in oat. Crop Science, v.34, p.915-922, 1994. 
MOTTO, M.; MOLL, R.H. Prolificacy in maize: a review. Maydica, v.27, p.53-76, 1983.

NASS, L.L. Variabilidade genética de populações semi-exóticas de milho. Piracicaba, 1992. 136p. Tese (Doutorado) - Escola Superior de Agricultura "Luiz de Queiroz", Universidade de São Paulo.

OBILANA, A.T.; HALLAUER, A.R.; SMITH, O.S. Estimates genetic variability in a maize interpopulation. The Journal of Heredity, v.70, p.127-132, 1979.

OTEGUI, M.E.; BONHOMME, R. Grain yield components in maize I. Ear growth and kernel set. Field Crops Research, v.53, p.247-256, 1998.

PARODA, R.S.; JOSHI, A.B. Genetic architecture of yield and components of yield in wheat. The Indian Journal of Genetics and Plant Breeding, v.30, p.298-314, 1970.

PAYNE, T.S.; STUTHMAN, D.D.; McGRAW, R.L.; BREGITZER, P.P. Physiological changes associated with three cycles of recurrent selection for grain yield improvement in oats. Crop Science, v.26, p.734-736, 1986.

PEREIRA, R.S.B. Caracteres correlacionados com a produção de grãos e suas alterações no melhoramento genético do milho (Zea mays L.). Piracicaba, 1990. 99p. Dissertação (Mestrado) - Escola Superior de Agricultura "Luiz de Queiroz", Universidade de São Paulo.

RAMALHO, M.A.P. Eficiência relativa de alguns processos de seleção intrapopulacional no milho baseados em familias não endógamas. Piracicaba, 1977. 122p. Tese (Doutorado) - Escola Superior de Agricultura "Luiz de Queiroz", Universidade de São Paulo.

RAMALHO, M.A.P.; SANTOS, J.B. dos; ZIMMERMANN, M.J. de O. Genética quantitativa em plantas autógamas. Goiânia: Editora da UFG, 1993. 271p. 
RASMUSSON, D.C. An evaluation of ideotype breeding. Crop Science, v.27, p.11401146, 1987.

RIBAUT, J.-M.; JIANG, C.; GONZALEZ-DE LEON, D. Identification of quantitative trait loci under drought conditions in tropical maize. 2. Yield components and marker-assisted selection strategies. Theoretical Applied Genetics, v.94, p.887896, 1997.

ROBINSON, H.F.; COMSTOCK, R.E.; HARVEY, P.H. Estimates of heritability and the degree of dominance in corn. Agronomy Journal, v.41, p.353-359, 1949.

ROBINSON, H.F.; COMSTOCK, R.E.; HARVEY, P.H. Genotypic and phenotypic correlation in corn and their implications in selection. Agronomy Journal, v.43, n.6, p.282-287, 1951.

RUSSEL, W.A.; EBEHART, S.A. Testcross of one and two ear types of corn belt maize inbreds. II. Stability of performance on different environments. Crop Science, v.8, n.3, p.248-251, 1968.

SAMPAIO, N.F. Propriedades genéticas e potencial para o melhoramento dos compostos de milho (Zea mays L.) ESALQ PB-4 e ESAL PB-5. Piracicaba, 1986. 105p. Dissertação (Mestrado) - Escola Superior de Agricultura "Luiz de Queiroz", Universidade de São Paulo.

SAN VICENTE, F.M.; HALLAUER, A.R. Inbreeding depression rates of materials derived from two groups of maize inbred lines. Revista Brasileira de Genética, v.16, n.4, p.989-1001, 1993.

SAS INSTITUTE. SAS OnlineDoc®: version 8. Cary, 1999.

SATTERTHWAITE, R.E. An approximate distribution of estimates of variance components. Biometrics, v.2, p.110-114, 1946.

SAX, K. The association of size differences with seed-coat pattern and pigmentation in Phaseolus vulgaris. Genetics, v.8, p.552-560, 1923. 
SIDWELL, R.J.; SMITH, E.L.; McNEW, R.W. Inheritance and interrelationships of grain yield and selected yield-related traits in a hard red winter cross. Crop Science, v.16, p.650-654, 1976.

SILVA, A.R. da; Análise genética de caracteres quantitativos em milho com o delineamento III e marcadores moleculares. Piracicaba, 2002. 143p. Tese (Doutorado) - Escola Superior de Agricultura "Luiz de Queiroz", Universidade de São Paulo.

SILVA, J.C.; HALLAUER, A.R. Estimation of epistatic variance in Iowa Stiff Stalk Synthetic maize. Journal of Heredity, v.66, n.5, p.290-296, 1975.

SINGH, P.S.; TERÁN, H.; MOLINA, A.; GUTIÉRREZ, A. Combining ability for seed yield and its components in common bean of Andean origin. Crop Science, v.32, p.81-84, 1992.

SMITH, C.S.; MOCK, J.J.; CROSBIE, T.M. Variability for morphological and physiological traits associated with barrenness and grain yield in the maize population, Iowa Upring Leaf Synthetic n.1. Crop Science, v.22, p.828-832, 1982.

SMITH, E.L. The genetics of wheat architecture. Annals of the Oklahoma Academy of Science, v.6, p.117-132, 1976.

SOBRADO, M.A. Drought responses of tropical corn. 1. Leaf area and yield components in the field. Maydica, v.35, p.221-226, 1990.

SOKAL, R.R.; ROHLF, F.J. Biometry: the principles and practice of statistics in biological research. New York: Freeman, 1995. 887p.

SOUZA JÚNIOR, C.L. Variâncias genéticas interpopulacionais e suas relações com a obtenção e seleção de híbridos. Piracicaba, 1988. 140p. Tese (Livre-Docência) Escola Superior de Agricultura "Luiz de Queiroz", Universidade de São Paulo.

SOUZA JÚNIOR, C.L.; GERALDI, I.O.; ZINSLY, J.R. Influence of tassel size on the expression of prolificacy in maize (Zea mays L.). Maydica, v.30, p.321-328, 1985. 
SOUZA JÚNIOR, C.L.; SANTOS, M.X.; MAGNAVACA, R.; GAMA, E.E.G. Estimativas de parâmetros genéticos na interpopulação de milho BR-105 x BR-106 e suas implicações no melhoramento. Pesquisa Agropecuária Brasileira, v.28, p.473-479, 1993.

SPRAGUE, G.F.; RUSSELL, W.A.; PENNY, L.H.; HORNER, T.W.; HANSON, W.D. Effect of epistasis on grain yield in maize. Crop Science, v.2, p.205-208, 1962.

STEEL, R.G.D.; TORRIE, J.H. Principles and procedures of statistics. New York: McGraw-Hill Book Company, 1980. 633p.

STUBER, C.W.; LINCOLN, S.E.; WOLFF, D.W.; HELENTJARIS, T.; LANDER, E.S. Identification of genetic factors contributing to heterosis in a hybrid from two elite maize inbred lines using molecular markers. Genetics, v.132, p.823-839, 1992.

STUBER, C.W.; MOLL, R.H.; HANSON, W.D. Genetic variances and interrelationships of six traits in a hybrid population of Zea mays L. Crop Science, v.6, p.455-458, 1966.

TANKSLEY, S.D. Mapping polygenes. Annual Review of Genetics, v.27, p.205-233, 1993.

TAVARES, F.C.A. Componentes da produção relacionados à heterose em milho (Zea mays L.). Piracicaba, 1972. 106p. Dissertação (Mestrado) - Escola Superior de Agricultura "Luiz de Queiroz", Universidade de São Paulo.

TYAGI, A.P.; POKHARIYAL, G.P.; ODONGO, O.M. Correlation and path coefficient analysis for yield components and maturity traits in maize (Zea mays L.). Maydica, v.33, n.2, p.109-119, 1988.

UNDERS ANDER, P.J. Yield and yield components response of maize to water stress in hybrid with different sources of stress tolerance. Maydica, v.32, n.1, p.49-60, 1987. 
VELÁSQUEZ, J.C. Estimativas de efeitos gênicos de diversos caracteres de milho Zea maiz L.) em solos ácidos e não ácidos. Piracicaba, 2000. 127p. Tese (Doutorado) Escola Superior de Agricultura "Luiz de Queiroz", Universidade de São Paulo.

VELDBOOM, L.R.; LEE, M. Molecular-marker-facilitated studies of morphological traits in maize. II: Determination of QTLs for grain yield and yield components. Theoretical Applied Genetics, v.89, p.451-458, 1994.

VENCOVSKY, R.; BARRIGA, P. Genética biométrica aplicada ao fitomelhoramento. Ribeirão Preto: Sociedade Brasileira de Genética, 1992. 496p.

VENCOVSKY, R.; MIRANDA FILHO, J.B.; SOUZA JÚNIOR, C.L. Quantitative genetics and corn breeding in Brazil. In: INTERNATIONAL CONFERENCE ON QUANTITATIVE GENETICS, 2, Raleigh, 1987. Proceddings. Sunderland: Sinauer Associates, 1988. p.465-477.

VIDAL-MARTÍNEZ, V.A.; CLEGG, M.D.; JOHNSON, B.E. Genetic studies on maize pollen and grain yield and their yield components. Maydica, v.46, p.35-40, 2001.

WHAN, B.R.; RATHGEN, A.J.; KNIGHT, R. Response to selection for grain yield and harvest index in $F_{2}, F_{3}$, and $F_{4}$ derived lines of two wheat crosses. Euphytica, v.31, p.139-150, 1982.

WOLF, D.P.; PETERNELLI, L.A.; HALLAUER, A.R. Estimates of genetic variance in an $\mathrm{F}_{2}$ maize population. The Journal of Heredity, v.91, n.5, p.384-391, 2000.

YOUNG, N.D. Constructing a plant genetic linkage map with DNA markers. In: PHILLIPS, R.L.; VALIC, I.K. DNA: based markers in plants. Dordrecht: Kluwer Academic, 1994. p.39-57.

ZENG, Z.-B. Precision mapping of quantitative trait loci. Genetics, v.136, p.1457-1466. 1994. 
ZENG, Z.-B. Theoretical basis for separation of multiple linked gene effects in mapping quantitative traits loci. Proceedings of the National Academy of Sciences of the United States of America, v.90, p.10972-10976, 1993. 
APÊNDICE 
Tabela 15. Resumo das análises de variâncias agrupadas por ambiente para a produção de grãos e seus componentes e ramificações do pendão.

\begin{tabular}{|c|c|c|c|c|c|c|c|c|}
\hline \multirow{4}{*}{$\begin{array}{c}\text { Caráter } \\
\text { PG } \\
\left(\text { g planta }^{-1}\right)\end{array}$} & \multirow[b]{2}{*}{ F.V. } & \multirow[b]{2}{*}{ GL } & \multicolumn{6}{|c|}{ Ambientes $^{b}$} \\
\hline & & & 1 & 2 & 3 & 4 & 5 & 6 \\
\hline & Prog (exp) & 245 & $589,87^{* *}$ & $559,14^{* *}$ & $614,56^{* *}$ & $419,77^{* *}$ & $362,95^{* *}$ & $378,96^{* *}$ \\
\hline & Prog x Linh (exp) & 245 & $725,40^{* *}$ & $697,12^{* *}$ & $889,89^{* *}$ & $594,78^{* *}$ & $463,90^{* *}$ & $496,93^{* *}$ \\
\hline & Resíduo & 404 & 362,75 & 309,83 & 353,30 & $175,13^{* *}$ & 195,18 & 235,28 \\
\hline & $\mathrm{CV}(\%)$ & & 15,17 & 13,24 & 12,37 & 13,66 & 13,91 & 17,01 \\
\hline & Média & & 125,54 & 132,96 & 151,96 & 96,90 & 100,41 & 90,19 \\
\hline PROL & Prog (exp) & 245 & $20,78^{* *}$ & $31,84^{* *}$ & $28,32 * *$ & $34,15^{* *}$ & $28,41^{* *}$ & $30,45^{* *}$ \\
\hline$\left(\right.$ esp planta $\left.{ }^{-1}\right)$ & Prog x Linh (exp) & 245 & $23,97^{* *}$ & $19,63^{*}$ & $27,45 * *$ & $24,25^{*}$ & $28,20^{* *}$ & $25,59^{*}$ \\
\hline & Resíduo & 404 & 15,79 & 23,45 & 19,33 & 19,19 & 21,38 & 21,20 \\
\hline & $\mathrm{CV}(\%)$ & & 12,45 & 13,51 & 12,16 & 13,05 & 13,03 & 13,56 \\
\hline & Média & & 1,01 & 1,13 & 1,14 & 1,06 & 1,12 & 1,07 \\
\hline & Prog (exp) & 245 & $49,18^{* *}$ & $36,23^{* *}$ & $30,99^{* *}$ & $47,42^{\text {** }}$ & $43,37^{* *}$ & $47,81^{* *}$ \\
\hline$\left(\mathrm{cm}\right.$ planta $\left.^{-1}\right)$ & Prog x Linh (exp) & 245 & $37,40^{* *}$ & $23,85^{* *}$ & $22,24^{* *}$ & $41,47^{* *}$ & $22,02^{*}$ & $33,03^{*}$ \\
\hline & Resíduo & 405 & 27,19 & 14,30 & 11,11 & 19,23 & 17,37 & 26,61 \\
\hline & $\mathrm{CV}(\%)$ & & 3,88 & 2,79 & 2,43 & 3,36 & 3,28 & 3,96 \\
\hline & Média & & 4,25 & 4,29 & 4,34 & 4,13 & 4,02 & 4,12 \\
\hline $\mathrm{CE}^{\mathrm{a}}$ & Prog (exp) & 245 & $0,98^{* *}$ & $0,91^{* *}$ & $0,88^{* *}$ & $0,85^{* *}$ & $0,84^{* *}$ & $1,01^{* *}$ \\
\hline$\left(\mathrm{cm} \mathrm{planta}{ }^{-1}\right)$ & Prog x Linh (exp) & 245 & $0,90^{* *}$ & $0,82^{* *}$ & $0,71^{* *}$ & $0,81^{* *}$ & $0,63^{* *}$ & $1,04^{* *}$ \\
\hline & Resíduo & 405 & 0,59 & 0,44 & 0,38 & 0,45 & 0,38 & 0,63 \\
\hline & $\mathrm{CV}(\%)$ & & 4,73 & 3,98 & 3,68 & 4,27 & 3,91 & 5,14 \\
\hline & Média & & 19,29 & 16,62 & 16,66 & 15,75 & 15,72 & 15,47 \\
\hline NGF & Prog (exp) & 245 & $6,79^{* *}$ & $6,16^{* *}$ & $5,87^{* * *}$ & $7,46^{* *}$ & $5,96^{* *}$ & $8,48^{* * *}$ \\
\hline (grãos esp..$^{-1}$ ) & Prog x Linh (exp) & 245 & $8,09^{* *}$ & $4,86^{* *}$ & $5,35^{* *}$ & $8,78^{* *}$ & $4,82^{* *}$ & $7,41^{* *}$ \\
\hline & Resíduo & 405 & 4,68 & 3,50 & 2,88 & 4,33 & 3,16 & 4,60 \\
\hline & $\mathrm{CV}(\%)$ & & 6,19 & 5,27 & 4,72 & 6,28 & 5,02 & 6,22 \\
\hline & Média & & 34,95 & 35,50 & 35,94 & 33,12 & 35,46 & 34,46 \\
\hline & Prog ( & 245 & $1,03^{* *}$ & $1,06^{* *}$ & $1,11^{* *}$ & $1,10^{* *}$ & $0,91^{* *}$ & $1,13^{* * *}$ \\
\hline (grãos fill. $^{-1}$ ) & inh $(\exp )$ & 245 & $0,60^{*}$ & $0,49^{* *}$ & $0,47^{* *}$ & $0,56^{* *}$ & $0,44^{\mathrm{ns}}$ & $0,53^{* *}$ \\
\hline & Resíduo & 405 & 0,49 & 0,35 & 0,30 & 0,36 & 0,41 & 0,37 \\
\hline & $\mathrm{CV}(\%)$ & & 5,92 & 4,84 & 4,54 & 5,10 & 5,47 & 5,15 \\
\hline & Média & & 11,86 & 12,15 & 12,13 & 11,82 & 11,70 & 11,75 \\
\hline & Prog (exp) & 245 & -- & $175,55^{* *}$ & $156,08^{* *}$ & $255,09^{* *}$ & $251,56^{* *}$ & $281,33^{* *}$ \\
\hline$\left(\right.$ gramas $\left.^{-1}\right)$ & nh (exp) & 245 & -- & $115,10^{* *}$ & $97,84^{* *}$ & $159,01^{* *}$ & $174,05^{* *}$ & $158,06^{*}$ \\
\hline & Resíduo & 405 & -- & 84,84 & 68,32 & 95,98 & 91,92 & 123,35 \\
\hline & $\mathrm{CV}(\%)$ & & -- & 5,43 & 4,78 & 6,07 & 6,94 & 8,08 \\
\hline & Média & & -- & 169,63 & 172,80 & 161,52 & 138,23 & 137,49 \\
\hline $\mathrm{RP}$ & Prog (exp) & 245 & $6,21^{* *}$ & $10,79^{* *}$ & $9,25^{* *}$ & $6,56^{* *}$ & $7,32^{* *}$ & $5,88^{* *}$ \\
\hline$\left(\right.$ ram pend..$\left.^{-1}\right)$ & Prog x Linh (exp) & 245 & $3,64^{*}$ & $4,69^{* *}$ & $4,31^{* *}$ & $3,67^{* *}$ & $3,95^{* *}$ & $3,22^{\text {ns }}$ \\
\hline & Resíduo & 405 & 3,00 & 3,47 & 2,76 & 2,39 & 2,62 & 2,70 \\
\hline & $\mathrm{CV}(\%)$ & & 10,38 & 10,34 & 8,99 & 9,89 & 10,24 & 11,40 \\
\hline & Média & & 16,69 & 18,01 & 18,47 & 15,63 & 15,82 & 14,41 \\
\hline
\end{tabular}

${ }^{\text {a }} \mathrm{QM}$ multiplicados por $10^{-3},{ }^{*},{ }^{* *} \mathrm{P} \quad 0,05$ e $\mathrm{P} \quad 0,01$ pelo teste de $F$, respectivamente., - Não avaliado neste ambiente. PG: Produção de grãos; PROL: prolificidade; DE: diâmetro da espiga; CE: comprimento da espiga; NGF: número de grãos por fileira; NFI: número de fileiras; P500: peso de 500 grãos; RP: número de ramificações do pendão. ${ }^{\text {b }}$ Ambiente 1: Estação Experimental Departamento de Genética, época 1 (E.E.LGN -1) ano 1999/2000; Ambiente 2: E.E.LGN-2, ano 2000/2001; Ambiente 3: E.E.LGN-3, ano 2000/2001; Ambiente 4: Estação Experimental Fazenda Caterpillar, ano 2000/20001; Ambiente 5: E. E. Fazenda Areão, ano 2000/2001; Ambiente 6: E.E.LGN-4, ano 2000/2001. 